U. S. DEPARTMENT OF COMMERCE NATIONAL BUREAU OF STANDARDS

REPORT OF THE

TWENTY-FIFTH NATIONAL CONFERENCE ON

WEIGHTS AND MEASURES

ATTENDED BY REPRESENTATIVES

FROM VARIOUS STATES

HELD AT THE NATIONAL BUREAU OF STANDARDS

WASHINGTON, D. C., JUNE 4, 5, 6, AND 7, 1935

MISCELLANEOUS PUBLICATION M156 

U. S. DEPARTMENT OF COMMERCE

DANIEL C. ROPER, Secretary

NATIONAL BUREAU OF STANDARDS

LYMAN J. BRIGGS, Director

\section{MISCELLANEOUS PUBLICATION M156}

REPORT OF THE

TWENTY-FIFTH NATIONAL CONFERENCE

ON

\section{WEIGHTS AND MEASURES}

ATTENDED BY REPRESENTATIVES

FROM VARIOUS STATES

HELD AT THE NATIONAL BUREAU OF STANDARDS

WASHINGTON, D. C., JUNE 4, 5, 6, and 7, 1935

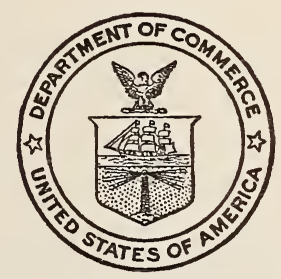

UNITED STATES

GOVERNMENT PRINTING OFFICE

WASHINGTON : 1936 



\section{OFFICERS AND COMMITTEES}

\section{OFFICERS}

(Serving during Twenty-fifth National Conference)

Presiding officer, JoHN P. MCBRIDE, director, State division of standards, Boston, Mass.

Secretary, F. S. Holвrook, National Bureau of Standards, Washington, D. C.

Treasurer, GEorge F. A USTIN, Jr., supervising inspector of weights and measures, Detroit, Mich.

(As elected by Twenty-fifth National Conference for the ensuing year)

President, Lyman J. Briggs, Director, National Bureau of Standards, Washington, D. C.

First vice president, JoHN P. McBride, director, State division of standards, Boston, Mass.

Second vice president, C. D. Ba ucom, State superintendent of weights and measures, Raleigh, N. C.

Third vice president, Martin L. LANG, State commissioner of weights and measures, Indianapolis, Ind.

Fourth vice president, J. C. Trnker, deputy State sealer, Columbus, Ohio.

Secretary, F. S. Holвrook, National Bureau of Standards, Washington, D. C.

Treasurer, GEORGE F. A USTIN, Jr., supervising inspector of weights and measures, Detroit, Mich.

\section{COMMITTEES \\ EXECUTIVE COMMITTEE}

(As elected by Twenty-fifth National Conference)

LYMAN J. BRIGGS.

JoHN P. McBRIDE.

C. D. BADCOM.

Martin L. Lang.

J. C. TINKEY.

F. S. Holbrook.

George F. Austin, Jr.

Ex officio.

Grorge S. Barnard, director, State bureau of foods and standards, Lansing, Mich.

JoHN S. BuRke, superintendent of weights and measures, Jersey City, N. J.

Howard E. CrawFord, inspector of weights and measures, Jacksonville, Fla.

H. N. Davis, deputy State commissioner of weights and measures, Montpelier, Vt.

UrbaN E. Dice, chief inspector of weights and measures of Allegheny County, Pittsburgh, Pa.

S. T. Griffith, chief, division of weights and measures, Baltimore, Md.

JoHn J. LevitT, State superintendent of standards, Springfield, Ill.

SETH L. LightF OOT, State inspector of weights and measures, Phoenix, Ariz.

C. R. McFADDEN, deputy sealer of weights and measures of Licking County, Pataskala, Ohio.

ROLLIN E. MEEK, chief State inspector of weights and measures, Indianapolis, Ind.

B. W. RAGLAND, chief, bureau of weights and measures, Richmond, Va.

C. J. REYNOLDS, director, State bureau of weights and measures, Albany, N. Y. Louis G. Waldman, commissioner of weights and measures, St. Louis, Mo.

George Warner, chief State inspector of weights and measures, Madison, Wis. WALTER G. WHITE, State commissioner of weights and measures, Concord, N. H.

S. H. WILson, State oil chemist, Atlanta, Ga. 


\section{COMMITTEE ON SPECIFICATIONS AND TOLERANCES}

(Standing committee)

F. S. Holbrook, National Bureau of Standards, Washington, D. C.

Charles M. Fuller, city and county sealer of weights and measures, Los Angeles, Calif.

JOSEPH G. ROGERS, assistant State superintendent of weights and measures, Trenton, N. J.

JoHN P. MCBRIDE, director, State division of standards, Boston, Mass.

Grorge F. Austin, Jr., ${ }^{1}$ supervising inspector of weights and measures, Detroit, Mich.

\section{ACTING COMMITTEES FOR THE TWENTY-FIFTH NATIONAL CONFERENCE}

Special Committee on Resolutions.-James A. Borle, of Portland, Maine, chairman; Walter G. White, of New Hampshire; and GlenN L. Berry, of Monmouth County, N. J.

Commiltee on Resolutions.-C. D. BAUсом, of North Carolina, chairman; JoHN J. LevitT, of Illinois; George S. Barnard, of Michigan; Walter F. Stiles, of Connecticut; Alexander Hamilton, of New York, N. Y.; William F. Steinel, of Milwaukee, Wis.; and JACOB M. VANDerslice, of Philadelphia County, Pa. Committee on Nominations.-J. C. Tinker, of Ohio, chairman; H. N. DAvis, of Vermont; John S. Burke, of Jersey City, N. J.; Howard E. Crawford, of Jacksonville, Fla.; and Rollin E. MeEx, of Indiana.

In Charge of Exhibits.-B. L. PAGE.

In Charge of Registrations.-Mrs. H. E. Rosenberger.

$1 \mathrm{Mr}$. Austin consented to serve on the committee only during the period of the Twenty-fifth National Conference. 


\section{PERSONS ATTENDING THE CONFERENCE DELEGATES-STATE, CITY, AND COUNTY OFFICIALS ARIZONA}

State

Seth L. Lightfoot, inspector of weights and measures, Statehouse, Phoenix.

\section{CONNECTICUT}

State

WALter F. Stiles, captain, department of State police, 100 Washington Street, Hartford.

C. L. KLOCKeR, department of State police, 100 Washington Street, Hartford.

\section{DISTRICT OF COLUMBIA}

District

George M. Roberts, superintendent of weights, measures, and markets, $467 \mathrm{C}$ Street, Washington.

W. C. Drller, chief inspector of weights, measures, and markets, $467 \mathrm{C}$ Street, Washington.

John L. F. KeEnan, inspector of weights, measures, and markets, $467 \mathrm{C}$ Street, Washington.

\section{FLORIDA}

State

Nalls Berryman, assistant State chemist, department of agriculture, Tallahassee.

City: Jacksonville

HowARD E. CRAWFORD, inspector of weights and measures, Utilities Building.

\section{GEORGIA}

State

S. H. Wrlson, State oil chemist, 134 State Capitol, Atlanta.

J. T. Williams, Sr., inspector, State oil division, Americus.

\section{ILLINOIS}

State

City: Chicago.

JонN J. LEvitT, superintendent of standards, Capitol Building, Springfield.

JAMES O'KEEFE, inspector of weights and measures, City Hall.

\section{INDIANA}

State

Martin L. LaNG, commissioner of weights and measures, Statehouse Annex, Indianapolis.

Rollin E. MEEK, chief inspector of weights and measures, Statehouse Annex, Indianapolis.

Herbert G. MeYer, inspector of weights and measures, Statehouse Annex, Indianapolis.

City:

East Chicago

Gary

Mrs. Clark MCQuilkin, sealer of weights and measures.

Thomas G. Nason, sealer of weights and measures.

County: Cass

ures, Logansport. 


\section{KENTUCKY}

City: Louisville............ WrLliam H. IsIng, Jr., chief inspector of weights and measures, 201 City Hall.

\section{MAINE}

State

Jorn H. Austin, deputy sealer of weights and measures, Augusta.

City:

Portland

Waterville.

JAMES A. Boyle, sealer of weights and measures, City Building.

William A. JoNes, sealer of weights and measures, City Hall.

\section{MARYLAND}

City: Baltimore

County: Anne Arundel.

State

City:

Beverly

Springfield

Taunton

State

City:

Detroit

Lansing

County:

Jackson

Washtenaw

- IrVing G. WhenLer, sealer of weights and meas-

City: St. Louis ures, 140 South Jackson Street, Jackson.

George P. Smith, sealer of weights and measures, Courthouse, Ann Arbor.

\section{MISSOURI}

S. T. Griffith, chief, division of weights and measures, City Hall.

Charles G. Crocketr, inspector of weights and measures, City Hall.

JoHn R. GraEFF, inspector of weights and measures, City Hall.

George H. Leitha user, inspector of weights and measures, City Hall.

Thomas J. NAPFEL, inspector of weights and measures, City Hall.

Elmer E. Nicholson, inspector of weights and measures, City Hall.

Fred J. O'Gorman, inspector of weights and measures, City Hall.

Elmer S. Pierpont, inspector of weights and measures, City Hall.

HENRY J. SLITZER, assistant inspector of weights and measures, City Hall.

Mrs. TABITha C. MCGinnis, inspector of weights and measures, Glen Burnie.

\section{MASSACHUSETTS}

John P. MCBRIDe, director of standards, Statehouse, Boston.

Robert J. Rafferty, sealer of weights and measures, City Hall.

E. M. BeEBE, deputy sealer of weights and measures. City Hall.

\section{MICHIGAN}

George S. Barnard, director, bureau of foods and standards, Lansing.

George F. Austin, Jr., supervising inspector of weights and measures, 1300 Beaubien Street.

CARL A. BUNDENTHAL, sealer of weights and measures, Municipal Market Building.

Lours G. WALdMAN, commissioner of weights and measures, 12 City Hall. 


\section{NEW HAMPSHIRE}

State

State

City:

Elizabeth

Jersey City

Newark

County:

Bergen

Cape May

Gloucester

Hudson

Mercer

Middlesex

Monmouth

Morris

Passaic

Somerset

Sussex

City:

Binghamton

Middletown

New York

Rochester

Rome
WALter G. WhIte, commissioner of weights and measures, Statchouse, Concord.

\section{NEW JERSEY}

JosepH G. Rogers, assistant superintendent and secretary, department of weights and measures, 187 West Hanover Street, Trenton.

Rowland K. BodenWIEser, assistant superintendent of weights and measures, 187 West Hanover Street, Trenton.

ElliotT B. Holton, assistant superintendent of weights and measures, 187 West Hanover Street, Trenton.

HARRY S. Provost, assistant superintendent of weights and measures, 187 West Hanover Street, Trenton.

ArCHIE T. SMITH, inspector of weights and measures, 187 West Hanover Street, Trenton.

William J. Bender, superintendent of weights and measures, City Hall.

JoHN S. BurKe, superintendent of weights and measures, City Hall.

Willard E. REED, superintendent of weights and measures, City Hall.

A. F. Barnard, superintendent of weights and measures, Hackensack.

Gilbert S. Smith, superintendent of weights and measures, Avalon.

William P. ABDill, superintendent of weights and measures, Woodbury.

Thomas J. WALDRon, superintendent of weights and measures, Courthouse, Jersey City.

RALPH M. BODENWIESER, superintendent of weights and ineasures, Trenton.

Charles $H$. EngelHard, superintendent of weights and measures, County Offices, New Brunswick.

GLENN L. BERRy, superintendent of weights and measures, 706 Eighth Avenue, Asbury Park.

Charles S. Wandling, superintendent of weights and measures, Courthouse, Morristown.

William Mrller, superintendent of weights and measures, 2 Laurel Street, Paterson.

Oliver B. Mathews, superintendent of weights and measures, Courthouse, Somerville.

R. Lee Slater, superintendent of weights and measures, Newton.

\section{NEW YORK}

L. E. REED, sealer of weights and measures.

Lloyd W. Funman, sealer of weights and measures, 5 Winchester Avenue.

Alexander Hamilton, deputy commissioner, department of public markets, weights, and measures, Municipal Building.

MARTIN J. MACK, sealer of weights and measures, 34 Court Street.

W. E. OLIVER, sealer of weights and measures, City Hall. 
County:

NEW YORK-Continued

Monroe

Fred J. Young, sealer of weights and measures, 1400 South Avenue, Rochester.

Oswego

Tioga

L. M. FLOwER, sealer of weights and measures, Lycoming.

HenRy L. Emmons, sealer of weights and measures, Spencer.

\section{NORTH CAROLINA}

State . . . . . . D. BAUCOM, superintendent of weights and

City: Winston-Salem measures, box 1066, Raleigh.

B. K. Jones, sealer of weights and measures.

OHIO

State

J. C. Tinkey, deputy State sealer, 710 State Office Building, Columbus.

City: Toledo

William C. Witfoth, sealer of weights and measures, 555 Erie Street.

County:

Cuyahoga.

George A. Fischer, deputy sealer of weights and measures, New Courthouse, Cleveland.

Licking

Sandusky

C. R. MCFADDEN, deputy sealer of weights and measures, Pataskala.

RAY A. GoEBEL, deputy sealer of weights and measures, Fremont.

Trumbull. . ........... J. G. KIRKPATRICK, deputy sealer of weights and

Wayne measures, Courthouse, Warren.

Albert S. Weber, deputy sealer of weights and measures, Courthouse, Wooster.

City:

\section{PENNSYLVANIA}

Allentown

JAMES E. MCHUGH, inspector of weights and measures, City Hall.

Harrisburg -.......... GEORGE B. NERINGER, inspector of weights and measures.

New Kensington.

JoHN H. Evans, inspector of weights and measures.

York

Irvin R. Shultz, inspector of weights and measures, City Hall.

County:

Allegheny

URBAN E. Dice, chief inspector of weights and measures, Courthouse, Pittsburgh.

Centre

Franklin

G. A. Spearly, inspector of weights and measures, Bellefonte.

ROY G. KELL, inspector of weights and measures, 358 East Catherine Street, Chambersburg.

Indiana

H. T. Miller, inspector of weights and meas. ures, Indiana.

Mifflin

F. M. DIPPERY, inspector of weights and measures, Lewistown.

Philadelphia

EDWIN C. EMHARDT, supervisor, bureau of weights and measures, 306 City Hall, Philadelphia.

JoHN B. MCCABE, district supervisor, bureau of weights and measures, 306 City Hall, Philadelphia.

JACOB M. VANDERSLICE, district supervisor, bureau of weights and measures, 306 City Hall, Philadelphia.

Fred KURz, clerk and inspector, bureau of weights and measures, 306 City Hall, Philadelphia.

Pike..... ures, Matamoras. 
County-Continued.

Union.... CALviN F. Blouch, inspector of weights and

Westmoreland measures, Lewisburg.

EDWARD D. ANDERSON, inspector of weights and measures, Courthouse, Greensburg.

F. W. MaINs, inspector of weights and measures, 1801 Victoria Avenue, Arnold.

\section{VERMONT}

State

H. N. Davis, deputy commissioner of weights and measures, Montpelier.

\section{VIRGINIA}

State

J. H. MEeK, director, division of markets, 1030 State Office Building, Richmond.

M. A. HUBBARD, inspector of weights and meas-

City: ures, 1030 State Office Building, Richmond.

Danville . . . . . . . GEORGE S. DYER, sealer of weights and measures, 812 Green Street.

Richmond

B. W. RAGLAND, chief, bureau of weights and measures.

C. D. Garber, deputy sealer of weights and measures.

County: Arlington......... E. M. Moreland, inspector of weights and measures, Courthouse, Clarendon.

\section{WEST VIRGINIA}

State

S. M. MiLler, inspector of weights and measures, Charleston.

Patsy J. Pellegrini, inspector of weights and measures, Charleston.

County: Marion........... H. D. Martin, sealer of weights and measures, Fairmont.

\section{WISCONSIN}

City: Milwaukee.

William F. Steinel, sealer of weights and measures, 1331 North Fifth Street.

\section{OTHER DELEGATES, AND GUESTS APPEARING ON THE PROGRAM}

BEAN, H. S., National Bureau of Standards, Washington, D. C.

BEARCE, H. W., National Bureau of Standards, Washington, D. C.

Braithwaite, W. E., National Bureau of Standards, Washington, D. C.

CAREY, L. C., specialist in package standardization, Bureau of Agricultural Economics, United States Department of Agriculture, Washington, D. C.

Crittenden, E. C., Assistant Director, National Bureau of Standards, Washington, D. C.

Drckinson, H. C., National Bureau of Standards, Washington, D. C.

Dickinson, Hon. JoHn, Assistant Secretary of Commerce, Washington, D. C.

ELY, E. W., National Bureau of Standards, Washington, D. C.

Frisbie, W. S., chief, division of State cooperation, Food and Drug Administration, United States Department of Agriculture, Washington, D. C.

Gould, R. E., National Bureau of Standards, Washington, D. C.

HARRISon, M. J. J., chairman, committee on yards and terminals, American Railway Engineering Association, 574 Union Station Building, Chicago, Ill.

Holbrook, F. S., National Bureau of Standards, Washington, D. C.

Judson, L. V., National Bureau of Standards, Washington, D. C.

McAllister, A. S., Assistant Director, National Bureau of Standards, Washington, D. C.

MILLER, D. R., National Bureau of Standards, Washington, D. C.

Peffer, E. L., National Bureau of Standards, Washington, D. C.

PIENKowskY, A. T., National Bureau of Standards, Washingto n, D. C.

Sмrт, D. V., National Bureau of Standards Master Scale Depot, 5800 W. 69th Street, Clearing Station, Chicago, Ill. 
Smith, RalPH W., National Bureau of Standards, Washington, D. C.

So dDER, Wilmer, National Bureau of Standards, Washington. D. C.

Stroop, D. V., engineer, and secretary, division of marketing, American Petroleum Institute, 50 West Fiftieth Street, New York, N. Y.

\section{GUESTS REPRESENTING MANUFACTURERS OF WEIGHING AND MEASURING DEVICES}

American Can Co:

Henry B. Todrtellot, New York, N. Y.

Elmer Nald, salesman, 104 South Michigan Avenue, Chicago, Ill.

Barnes Products (Inc.): W. J. Barnes, president, Detroit, Mich.

Becker, Christian (Inc.): C. A. BEcker, manager, 147 Eighth Street, Jersey City, N. J.

Black \& Decker Manufacturing Co.: E. E. Poweld, manager, loadometer sales, Towson, Md.

Bowser, S. F., \& Co. (Inc.):

C. P. Griffith, chief engineer, Fort Wayne, Ind.

E. C. MARSH, sales manager, Fort Wayne, Ind.

Brodie, R. N., Co. (Inc.): D. W. KIngsueY, 425 Chrysler Building, New York, N. Y.

Buffalo Meter Co.: T. J. Harrington, Buffalo, N. Y.

Chatillon, John, \& Sons:

P. T. Borteld, vice president, 89 Cliff Street, New York, N. Y.

J. George Hugel, 89 Cliff Street, New York, N. Y.

Continental Can Co.: O. G. J А коB, division sales manager, 100 East Forty-second Street, New York, N. Y.

Dayton Pump \& Manufacturing Co.: G. W. ЕіснноғF, eastern district manager, 441 Lexington Avenue, New York, N. Y.

Erie Meter Systems (Inc.):

L. O. Carlson, president, Erie, Pa.

N. A. CARLson, vice president, Erie, $\mathrm{Pa}$.

Exact Weight Scale Co.: K. B. NeFr, secretary-treasurer, Columbus, Ohio.

Fairbanks, Morse \& Co.:

C. A. Hennie, sales representative, 205 Water Street, Baltimore, Md.

Jerome KenNey, salesman, 205 Water Street, Baltimore, Md.

Gilbert \& Barker Manufacturing Co.:

K. S. EDwards, sales manager, Springfield, Mass.

J. A. LogaN, manager, new products division, Springfield, Mass.

S. C. Hope, Springfield, Mass.

Gurley, W. \& L. E.:

Charles I. DaY, president, 514 Fulton Street, Troy, N. Y.

Franklin G. Williams, Washington representative, 3621 Newark Street, Washington, D. C.

Hayes Equipment Manufacturing Co.: W. F. VogeL, general sales manager, Wichita, Kans.

Hobart Manufacturing Co.:

S. M. Templeton, assistant manager, Dayton scale division, Troy, Ohio.

John W. MilewsKi, Washington manager, Dayton scale division, 43 Florida Avenue NE., Washington, D. C.

Howe Scale Co.:

E. P. VRoOMe, eastern sales manager, 111 Eighth Avenue, New York, N. Y.

C. A. Lindsay, branch manager, 1011 Filbert Street, Philadelphia, Pa.

Huffman Manufacturing Co.: Horace M. Huffuan, president, Dayton, Ohio.

Industrial Equipment Co.: F. J. Rush, 116 Key Highway, Baltimore, Md.

International Business Machines Corporation:

HaRRY S. Evans, Washington manager, 1111 Connecticut Avenue, Washington, D. C.

L. S. Smithers, special representative, 270 Broadway, New York, N. Y.

International Ticket Scale Corporation: W. G. FitzGERALD, 17 East Forty-fifth Street, New York, N. Y.

Jacobs Bros. Co. (Inc.): J. E. Woodland, sales manager, detectogram division, Brooklyn, N. Y.

Joyce-Cridland Co.: RoBERT J. WARD, eastern sales manager, Graybar Building, New York, N. Y.

Kleckner, Wm. H. (Inc.): W. H. KLeckNer, president, 907 East Joppa Road, Towson, Md. 
L N S Corporation: William H. Lolley, president, 71 Murray Street, New York, N. Y.

Logan-Allington Oil Equipment Co.: E. W. Allington, 17 Battery Place, New York, N. Y.

Losey Personal Weighing Co.: George H. Loser, 3311 Oakfield Avenue, Baltimore, Md.

Martin \& Schwartz (Inc.): E. O. HABHEGGER, district manager, 2636 West Girard Avenue, Philadelphia, Pa.

Milestone Meter Systems (Inc.): W. E. Milestone, president, 1603 East Twenty-seventh Street, Cleveland, Ohio.

Moore \& Kling (Inc.): Elmer M. KLING, Boston, Mass.

National Meter Co.: N. J. Miano, petroleum meter department manager, 4207 First Avenue, Brooklyn, N. Y.

National Pumps Corporation: ERIC S. Bergman, eastern manager, 122 East Forty-second Street, New York, N. Y.

Neptune Meter Co.:

John H. Ballantine, president, 50 West Fiftieth Street, New York, N. Y. R. K. BlanchaRd, vice president, 50 West Fiftieth Street, New York, N. Y. Charles S. Hazard, chief engineer, 50 West Fiftieth Street, New York, N. Y.

GLENN D. FRYE, research engineer, 50 West Fiftieth Street, New York, N. Y.

Oil Equipment Laboratories (Inc.): Lron McCANdLess, president, Rochester, $\mathrm{Pa}$.

Oil Products Appliance Co. (Inc.): John T. Gossetr, 100 Sixth Avenue, New York, N. Y.

Owens-Illinois Glass Co.:

EDWARD F. GLACKEN, sales manager, milk bottle division, 965 Wall Street, Toledo, Ohio.

John Duncan, Jr., 965 Wall Street, Toledo, Ohio.

Peerless Weighing Machine Co.:

HARRY M. GRISWOLD, vice president and general manager, 245 Fifth Avenue, New York, N. Y.

Leveretr D. Chambers, secretary, 245 Fifth Avenue, New York, N. Y.

E. M. Schiemer, 245 Fifth Avenue, New York, N. Y.

Pittsburgh Equitable Meter Co.:

W. H. MARSH, chief engineer, liquid meter division, 400 North Lexington Avenue, Pittsburgh, Pa.

H. I. Beardsley, manager, oil and gasoline meter division, 400 North Lexington Avenue, Pittsburgh, $\mathrm{Pa}$.

M. J. HARPER, New York manager, 50 Church Street, New York, N. Y.

Royal Scale Co.: B. B. Rochestie, Trenton, N. J.

Service Station Equipment Co.:

J. C. WoodFord, chief engineer, Conshohocken, Pa.

O. L. Holcombe, engineer, Conshohocken, $\mathrm{Pa}$.

D. S. Willson, testing engineer, Conshohocken, Pa.

C. L. McMollen, sales representative, Conshohocken, $\mathrm{Pa}$.

Seraphin Test Measure Co.: THEo. A. Seraphin, president, 1314 North Seventh Street, Philadelphia, Pa.

Sharpsville Boiler Works Co.: Charles D. FaGan, president, Sharpsville, Pa.

Standard Computing Scale Co.: M. D. Ribble, vice president of sales, Detroit, Mich.

Streeter-Amet Co.:

Harry M. Roeser, 4101 Ravenswood Avenue, Chicago, Ill.

William Waterman, superintendent, 4101 Ravenswood Avenue, Chicago, Ill.

Toledo Scale Co.:

S. Q. Bennetr, manager, service and weights and measures, Toledo, Ohio.

SidNEY F. MASHBIR, in charge Government sales division, 802 McLachlen Building, Washington, D. C.

Tokheim Oil Tank \& Pump Co.: G. U. BraKe, Fort Wayne, Ind.

Torsion Balance Co.: A. T. Millroy, sales manager, 92 Reade Street, New York, N. Y.

Turner Automatic Devices (Inc.): H. C. TuRner, president, 205 East Fortysecond Street, New York, N. Y.

Wayne Co.:

Charles C. Neale, manager, weights and measures division, Fort Wayne, Ind.

M. C. Brown, 608 American Building, Baltimore, Md. 


\section{GUESTS REPRESENTING TRADE AND ENGINEERING ASSOCIATIONS}

American Petroleum Institute: David V. STroop, engineer and secretary,

Division of Marketing, 50 West Fiftieth Street, New York, N. Y.

American Railway Engineering Association: M. J. J. HARRIson, chairman, committee on yards and terminals, 574 Union Station Building, Chicago, Ill.

Gasoline Pump Manufacturers Association: G. Denny Moore, managing director, 230 Park Avenue, New York, N. Y.

Glass Container Association:

W. S. RichaRDS, chairman, standardization committee, 965 Wall Street, Toledo, Ohio.

Victor L. HaLL, secretary, standardization committee, 19 West Fortyfourth Street, New York, N. Y.

\section{GUESTS REPRESENTING BUSINESS AND INDUSTRY}

Balster, Joseph B., plant manager, Independent Oil Co., Rosslyn, Va.

BERGER, EVELYN, secretary to Washington manager, Lord Baltimore Filling Stations (Inc.), 1614 K Street, Washington, D. C.

Blair, C. E., purchasing department, Sun Oil Co., Philadelphia, Pa.

Bohart, J. G., Sinclair Refining Co., 45 Nassau Street, New York, N. Y.

Bowling, Edward E., 5209 Norwood Avenue, Baltimore, Md.

Clark, W. G., chief lubricating engineer, The Pure Oil Co., 35 East Wacker Drive, Chicago, Ill.

EAton, A. K., purchasing agent, Shell Eastern Petroleum Products (Inc.), 50 West Fiftieth Street, New York, N. Y.

Ehlers, C. H., chief engineer, The Atlantic Refining Co., 260 South Broad Street, Philadelphia, Pa.

Fitzpatrick, Edward I., Munsey Building, Washington, D. C.

Fox, Ralph, mechanic, Consolidation Coal Co., Monongah, W. Va.

Griswold, A. G., Crew Levick Co., Rosslyn, Va.

GrondacH, O. H., Sinclair Refining Co., 45 Nassau Street, New York, N. Y.

HANNA, J. P., assistant district manager, Sinclair Refining Co., 205 East Fortysecond Street, New York, N. Y.

Hargen, S., engineer, Socony Vacuum Oil Co. (Inc.), 26 Broadway, New York, N. Y.

HAYES, E. A., Washington manager, Lord Baltimore Filling Stations (Inc.), $1614 \mathrm{~K}$ Street, Washington, D. C.

MCCABE, GeORge P., 705 Security Building, Washington, D. C.

O'Connels, T. J., chief engineer, American Oil Co., American Building, Baltimore, Md.

Wakefield, A., general superintendent, American Oil Co., Baltimore, Md.

Woodward, C. P., equipment engineer, Shell Petroleum Corporation, St. Louis, Mo.

\section{GUESTS REPRESENTING RAILROADS}

EPRIGHт, A. W., supervisor scales and weighing, Pennsylvania Railroad, Altoona, $\mathrm{Pa}$.

LAWREnCE, E. Kent, general scale inspector, Baltimore \& Ohio Railroad, Baltimore, $\mathrm{Md}$.

Pherigo, J. L., chief scale inspector, Southern Railway, Washington, D. C.

Propst, H. C., chief scale inspector, Chesapeake \& Ohio Railway, Richmond, Va.

\section{GUESTS REPRESENTING GOVERNMENT DEPARTMENTS}

Carer, L. C., specialist in package standardization, Bureau of Agricultural Economics, United States Department of Agriculture, Washington, D. C.

Frisbie, W. S., chief, division of State cooperation, Food and Drug Administration, United States Department of Agriculture, Washington, D. C.

GAST, Fred W., chief, division of engineering and weighing, Bureau of Customs, Treasury Department, Washington, D. C.

MilleR, J. C., skilled draftsman, Post Office Department, Washington, D. C.

\section{OTHER GUESTS}

Jacoss, Edrth G., secretary, Scale Journal Publishing Co., 7152 Ridgeland Avenue, Chicago, Ill.

Orr, Frank F., Newark, Ohio.

Smith, Edwin C., 145 Nassau Avenue, Huntington, N. Y. 
Officers and committees

Persons attending the Conference

FIRST SESSION-MORNING OF TUESDAY, JUNE 4, 1935

Opening address by E. C. Crittenden, Assistant Director, National Bureau of Standards.

Appointment of temporary chairman Abstracts of State reports:

Arizona, Seth L. Lightfoot

California, C. E. Tucker

Connecticut, Walter F. Stiles

District of Columbia.

Georgia, S. H. Wilson

Illinois, John J Levitt

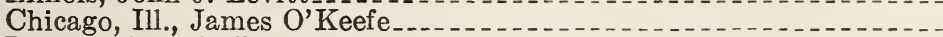

Indiana, Martin L. Lang .

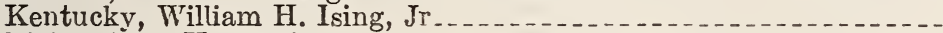

Maine, John H. Austin

Maryland, S. T. Griffith.

Massachusetts, John P. McBride

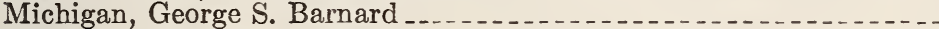

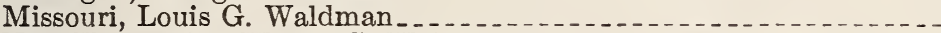

New Hampshire, Walter G. White.

Announcements

SECOND SESSION-AFTERNOON OF TUESDAY, JUNE 4, 1935

Abstracts of State reports-Continued:

New Jersey, Joseph G. Rogers.

New York, Alexander Hamilton.

Ohio, J. C. Tinkey -

Pennsylvania Urban E Dice

Vermont, H. N. Davis.

Virginia, J. H. Meek

West Virginia, P. J. Pellegrini

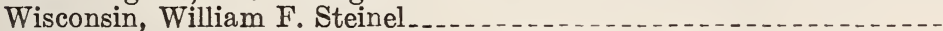

Wyoming, Arling Gardner

Abstracts of reports of representatives of State associations of weights and measures officials:

Indiana Association of Inspectors of Weights and Measures, Rollin E. Meek.

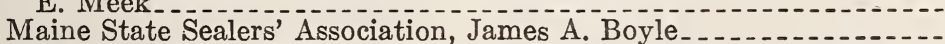

Massachusetts Association of Sealers of Weights and Measures, E. M. Beebe

Michigan Association of Weights and Measures Officials, Irving G. Wheeler

New Jersey Weights and Measures Association, Joseph G. Rogers.-

Ohio Sealers Association, C. R. McFadden.

Election of presiding officer for 1935 meeting

Report of Committee on Specifications and Tolerances on specifications, tolerances, and regulations for person weighers, presented by F. S. Holbrook, chairman

Discussion of above report. 


\section{THIRD SESSION-MORNING OF WEDNESDAY, JUNE 5, 1935}

Announcement, and appointment of special committee on resolutions - - -

Federal specification AAA-S-121 for weighing scales, by Ralph W. Smith, National Bureau of Standards

Discussion of report on specifications, tolerances, and regulations for person weighers-Continued.

Supervision over the buying of old gold, by Elliott B. Holton, assistant superintendent of weights and measures, State of New Jersey

A study of the promulgation of rules and regulations as applied to the various States of the Union, by C. D. Baucom, superintendent of weights and measures, department of agriculture, State of North Carolina_. . - . - .

The labeling and certification plan in connection with Federal specifications, by A. S. McAllister, Assistant Director, National Bureau of Standards ...

Demonstrations of recent developments in weighing scales, by representatives of manufacturers

Appointment of committees

Announcements

FOURTH SESSION-AFTERNOON OF WEDNESDAY, JUNE 5, 1935

Tour of the laboratories of the National Bureau of Standards . . . . . . .

FIFTH SESSION-MORNING OF THURSDAY, JUNE 6, 1935

Reconsideration of adoption of specification 9 for person weighers.....-..-

Demonstrations of recent developments in weighing scales, by representatives of manufacturers-Continued . . . . . . . . . . . . . . . .

Nontax-paid gasoline, by S. H. Wilson, oil chemist, State of Georgia

Report of special committee on resolutions, presented by Walter $\bar{G}$. White

Temperature of gasoline in underground storage, by B. W. Ragland, chief, bureau of weights and measures, Richmond, Va..........

Gasoline losses in storage and handling, by H. C. Dickinson, National Bureau of Standards

Report of Committee on Specifications and Tolerances on modification of several codes, presented by F. S. Holbrook, chairman

Address by Hon. John Dickinson, Assistant Secretary of Commerce.-.--

Weights and measures and petroleum products, by D. V. Stroop, secretary, division of marketing, American Petroleum Institute..........-

Sealed cans for dispensing lubricating oil, by Martin L. Lang, commissioner of weights and measures, State of Indiana...

Discussion of above paper

Report of Committee on Specifications and Tolerances on modification of code for vehicle tanks, presented by F. S. Holbrook, chairman......

Discussion of above report .

SIXTH SESSION-AFTERNOON OF THURSDAY, JUNE 6, 1935

Discussion of report of Committee on Specifications and Tolerances on modification of code for vehicle tanks - Continued. . .

Announcements representatives of manufacturers

Report of Committee on Specifications and Tolerances on modification of code for liquid-measuring devices, presented by F. S. Holbrook, chair-

man

Discussion of above report

Motor-truck scales and National Scale Men's Association activities, by M. J. J. Harrison, chairman, committee on yards and terminals, Ameri-

A board of adjustment, by Edwin C. Emhardt, supervisor, bureau of weights and measures, Philadelphia County, Pa........ 
SEVENTH SESSION-MORNING OF FRIDAY, JUNE 7, 1935

Report of Committee on Specifications and Tolerances on modification of several codes-Continued

Reconsideration of adoption of specification 16 for liquid-measuring de-

vices, as amended.several codes-Continued

Resolution conferring authority to make certain revisions in codes of specifications and tolerances.

The Byrd bill to consolidate Federal standard-container legislation, by L. C. Carey, specialist in package standardization, Bureau of Agricultural Economics, United States Department of Agriculture

Testing equipment for large-capacity scales._.

Paper of Jacob M. Vanderslice, district supervisor, bureau of weights and measures, Philadelphia County, $\mathrm{Pa}$

The testing of beer barrels, by Willard E. Reed, superintendent of weights and measures, Newark, N. J

Discussion of above paper

The weights and measures provisions of the Copeland bill to revise the Federal Food and Drugs Act, by W. S. Frisbie, chief, division of State cooperation, Food and Drug Administration, United States Department of Agriculture

The Annual Assay Commission, by H. W. Bearce, National Bureau of Standards

Report of committee on nominations, and election of officers

The control of "bootleg" coal, by S. T. Griffith, chief, division of weights

and measures, Baltimore, Md sealer, State of Ohio

Discussion of above paper
Undercover buying as an aid to law enforcement, by George M. Roberts, superintendent of weights, measures, and markets, District of Columbia

Report of committee on resolutions, presented by C. D. Baucom, chairman:

In memory of Dr. Samuel W. Stratton

In memory of Dr. George K. Burgess._.

In memory of our departed brothers...

Appreciation to officials cooperating

Appreciation to the Director and staff of the National Bureau of

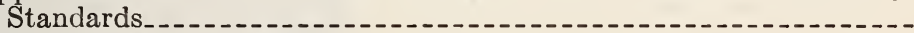

Appreciation to the Press.

In relation to rules of procedure for the National Conference...

Discussion of above report.

Creation of committee on constitution and bylaws.

Report of the treasurer, George F. Austin, Jr

Consideration of hotel headquarters for the Twenty-Sixth National Conference.

Motion in relation to expenditures.

Tribute to John H. Austin 


NBS Miscellaneous Publication M156

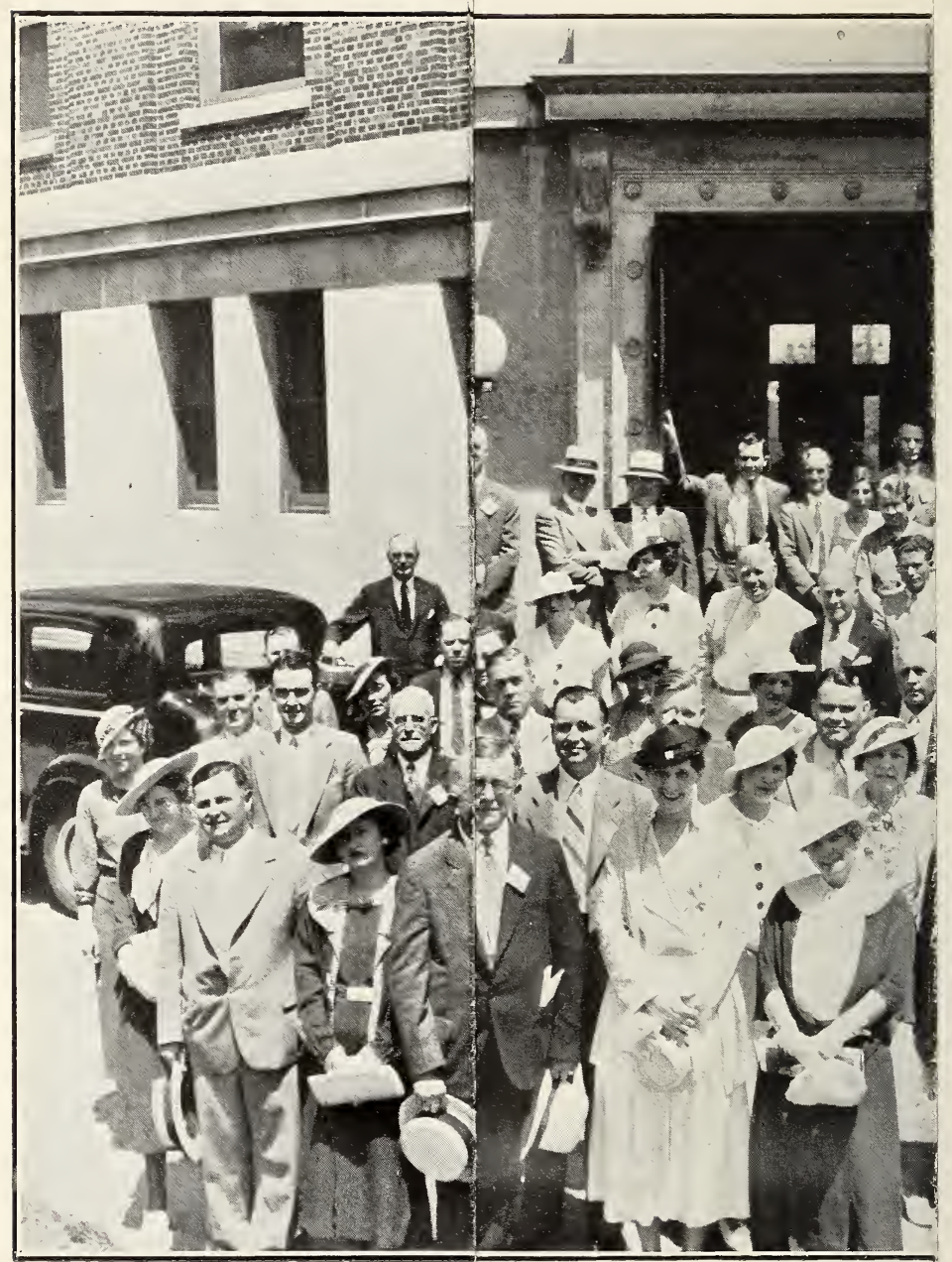

1-fifth National Conference on Weig 


\title{
REPORT OF THE TWENTY-FIFTH NATIONAL CONFERENCE ON WEIGHTS AND MEASURES
}

\author{
HELD AT THE NATIONAL BUREAU OF STANDARDS, \\ WASHINGTON, D. C., June 4-7, 1935
}

\section{FIRST SESSION-MORNING OF TUESDAY, JUNE 4, 1935}

(The Conference was called to order at 11:12 a. m., by F. S. Holbrook, secretary of the Conference.)

Mr. Holвroок. Ladies and gentlemen, delegates, and guests of the Twenty-Fifth National Conference on Weights and Measures, in the absence of higher officers of the Conference, it becomes my duty, as secretary of the Conference, to call this meeting to order.

Since the last meeting we have suffered a very great loss by the untimely death of Dr. George K. Burgess, then Director of the National Bureau of Standards and President of the Conference.

Both of our vice presidents, selected at the last meeting, have retired from weights and measures work.

In such a situation, as I have said, it becomes necessary for the secretary to call the meeting to order. At the conclusion of the first number on the program, I will call one of your number to preside over this session. Early this afternoon you will be asked to select a presiding officer for the 1935 meeting. The election of permanent officers for the ensuing year will take its usual place on our program.

This, as you know, is the first meeting of the Conference since 1931 and the outlook is for a very fine meeting this year.

Dr. Lyman J. Briggs, the Director of the National Bureau of Standards, was very much disappointed at finding it necessary to be out of town on official business. In his absence Mr. E. C. Crittenden, Assistant Director of the Bureau, will make the opening address to this Conference.

I take pleasure in introducing Mr. Crittenden.

\section{OPENING ADDRESS}

By E. C. Crittenden, Assistant Director, National Bureau of Standards

Gentlemen, it is a special pleasure to welcome here again the members of the National Conference on Weights and Measures. To you who have taken part in past Conferences we extend a welcome such as is due to old friends returning after 4 years of absence. The new members also we welcome no less cordially, in the confidence that this Conference and those to come will continue to bring about the friendships and the mutual understanding which have flowed from former meetings and which help us all to do our work better. 





Our pleasure in seeing you here again is, however, alloyed with some regrets as we look back over the changes which 4 years have wrought. Many faithful old members are not here today, and the vacancies in your list of officers bear mute testimony to the ravages of time and change.

Dr. Samuel Wesley Stratton, who served as your president for so many years, died suddenly at the Massachusetts Institute of Technology on October 18, 1931, a few months after the last Conference. Dr. George Kimball Burgess, who succeeded Dr. Stratton in the presidency at the Sixteenth Annual Conference in 1923, followed him in death by only a few months. Dr. Burgess was stricken with a cerebral hemorrhage in October 1931 . He recovered sufficiently to return to duty as Director of this Bureau, but suffered a second attack in his office on July 2, 1932, and died on his way from the Bureau to the hospital.

As a summary of Dr. Burgess' career, I cannot do better than to read a brief biographical note prepared by our present Director, Dr. Briggs.

\section{GEORGE KIMBALL BURGESS}

Dr. Burgess was born in Newton, Mass., January 4, 1874, and was a direct descendant of Thomas Burgess, of England, who settled in Sandwich, Mass., in 1638. He was educated in the public schools of Newton and later entered the Massachusetts Institute of Technology, where he graduated in 1896. Most graduate students of that period who were able to continue their studies abroad went either to Germany or England, but Burgess decided to study at the Sorbonne. This decision had a profound influence upon his later work. In Paris he became deeply interested in high temperature measurements under the guidance of Le Chatelier, and later translated Le Chatelier's book on this subject. Here he acquired a fluent use of the French language, which later was to prove of great service to him in important international conferences. Here also he met Mlle. Suzanne Babut, whom he married in 1902, and who survives him.

Following the award of his doctorate from the Sorbonne in 1901 with highest honors, Dr. Burgess joined the physics staff of the University of Michigan, and the following year was called to the University of California. In 1903 he entered the service of the National Bureau of Standards, 2 years after its organization, and began a series of notable researches in the field of pyrometry, in large part in collaboration with Dr. C. W. Waidner. These investigations included an extended study of optical pyrometry, platinum resistance thermometry at high temperatures, the determination of the melting points of pure metals, and the study of the selective radiation from incandescent bodies.

It was during this period (1908) that Waidner and Burgess proposed as an absolute standard of brightness the radiation from the interior of a black body immersed in a bath of pure platinum at its freezing point. Lack of suitable refractories made it impossible to carry out the experimental procedure at that time, but 20 years later as Director of the National Bureau of Standards, Dr. Burgess had the keen satisfaction of seeing the Waidner-Burgess standard experimentally realized by members of the Bureau staff.

His interest in the properties of materials at high temperatures led him into the field of physical metallurgy, and in 1913 he was made chief of the newly organized Metallurgical Division of the Bureau. This marks the second stage of his career. He took up this work with character istic energy and enthusiasm, 
and in the course of its development he demonstrated his marked ability as a technical executive. While directing this work, he still found time for his own researches on the causes of dangerous defects in railway materials. He demon. strated the practicability of measuring the temperature of steel rails as they pass through the rolls in the mill, which provides an important control as regards uniformity and quality. He also contributed to the development of an improved method for producing steel ingots from which sound rails could be rolled. His investigations have contributed materially to the safety of railway travel.

When Dr. Stratton closed his distinguished career at the Bureau in 1923 by his decision to accept the presidency of the Massachusetts Institute of Technology, Dr. Burgess was appointed his successor as Director of the National Bureau of Standards. This selection met with the whole-hearted approval of the Bureau staff. The progressive development of the work of the Bureau during the past 8 years under his direction bears witness to his wise adminis. tration. He was active in the development and final adoption of an international temperature scale and in support of the international program now under way to establish the electrical units in absolute measure. Through the research associate plan he developed industrial research at the Bureau in cooperation with industry and technical organizations. During the last year of his adminis. tration the new national hydraulic laboratory was completed and extensive facilities were provided for the study of radio wave phenomena.

His office door was always open. Interruptions did not seem to worry him. His visitor found him dignified, but friendly, alert, attentive. He reached de. cisions promptly. His voice was low, his sentences crisp. His sense of humor was keen, and he responded to it with quiet body-shaking laughter. Sedentary in his habits, he had little interest in sports and games. Recreation to him meant a good book and a plentiful supply of tobacco, or a long drive in an open car with a friend. He loved the sea, and a long cruise was for him an ideal vacation.

Dr. Burgess gave generously of his time and energy to further the interests of organizations engaged in the advancement of research and standardization. At the time of his death he was president of the National Conference on Weights and Measures, chairman of the Federal Specifications Board, the National Screw Thread Commission, and the Federal Fire Council, a director of the American Standards Association, and a member of the National Advisory Committee for Aeronautics. His term of office as chairman of the National Reserach Council expired on June 30. He was a past president of the American Society for Steel Treating, the Philosophical Society of Washington, the Washington Academy of Sciences, the American Society for Testing Materials, and the Cosmos Club. $\mathrm{He}$ was a member of the National Academy of Sciences (past treasurer), the American Institute of Mining and Metallurgical Engineers, the Optical Society of America, the American Institute of Metals, the Physical Society of France, the Iron and Steel Institute of Great Britain, and a fellow of the American Physio cal Society and the American Association for the Advancement of Science. Case and Lehigh had honored him with the degree of doctor of engineering.

His memory will be cherished by the staff of the organization to which he gave the greater part of his life, and by his numerous friends in scientific and industrial circles, not alone in America but throughout the world.

The National Bureau of Standards has been remarkably fortunate in having at its head through 31 years of its development two men of such outstanding ability as Dr. Stratton and Dr. Burgess. 
Fortunately also, the administration has continued the policy of naming as Director a man whose reputation is based upon fundamental scientific work. We are doubly fortunate in having another Director whose sound judgment and quick human sympathy command the affection as well as the respect of the whole staff. We are sorry indeed that Dr. Briggs cannot be here during your meeting this year. He wishes me to express his whole-hearted regret at his necessary absence and to give you his wishes for a most successful meeting. $\mathrm{He}$ has sent me a letter addressed to the National Conference on Weights and Measures, which I will read to you.

\section{The National Conference on Weights and Measures, clo The National Bureau of Standards, Washington, D. C.}

Gentlemen: I deeply regret that circumstances beyond my control make it impracticable for me to be at the National Bureau of Standards to welcome you on the occasion of your 1935 meeting. I regret my absence the more keenly because of the fact that no Conference has been held during the past 3 years. The members of the Bureau staff have greatly missed the valuable contacts which these meetings provide, and I hope that from now on your Conference may be held annually without interruption.

It is our desire also to supplement these contacts as far as possible through personal visits by our staff to the various States to meet the officials charged with the enforcement of weights and measures regulations.

In turn I trust that you will not fail to avail yourselves of any opportunity to visit the National Bureau of Standards.

From these closer contacts will result a better understanding of our mutual problems, which is an important step toward the ultimate goal of uniform regulations.

Sincerely yours,

\section{(Signed) LYMAN J. Briggs,}

\section{Director.}

As Dr. Briggs states in his letter, he looks for uniformity in weights and measures regulations. However, we feel this meeting, this conference of yours, presents an example of a way that might well be extended beyond the field of weights and measures, and that is to set up an ideal relationship between the Federal Government and State and local officials. Of course, we all know at this time what functions the National Conference plays in relation to our affairs. Some of our very distinguished officials differ with others as to what may be correct or what may not be correct, but all feel it desirable that they cooperate. The result is mutual assistance and mutual benefit in carrying out the functions which are divided between you and the Federal Government in such a way as to make them more effective. We hope, as Dr. Briggs has suggested, that this cooperation be continued and grow better as the years pass.

Your program discloses that this is the Twenty-fifth National Conference. It thus may well be a jubilee Conference. We trust, therefore, that you will find some time for relaxation and enjoyment as well as serious work during your stay in Washington.

A study of the 4-year interval will present some of the problems arising during that time. You still have to deal with such old problems as the sale of oil and gasoline and other commodities. I note, however, that on the final day of your program you have to deal with the subjects of beer barrels and bootleg coal. This is quite different from 4 years ago, when it was the former rather than the latter commodity which was the subject of "bootlegging." 
On Wednesday you are scheduled to make a trip through the Bureau, and at that time there will be guides placed at your disposal.

Finally, I note particularly your closing item, the suggestions for the program of the Twenty-sixth National Conference. We shall look forward to seeing you here again next year, and trust that these conferences will be as successful during the next 25 years as they have been during the last 25 .

In closing, I wish to emphasize Dr. Briggs' invitation to call on us and send us your questions at any time. We are at your service not only during the Conference, but throughout the year. Please feel sure that whatever we can do for you will be done with real pleasure. I thank you very much for your attention.

Mr. Holbrook. Thank you, Mr. Crittenden.

\section{APPOINTMENT OF TEMPORARY CHAIRMAN}

Mír. Holbrook. I am going to ask Mr. John P. McBride, director of standards of Massachusetts, to take charge of the meeting until this afternoon, when a presiding officer can be elected. Mr. McBride.

(At this point Mir. MeBride assumed the chair, as temporary chairman of the Conference.)

\section{ABSTRACTS OF STATE REPORTS :}

\section{ARIZONA}

By Seth I. Lighrfoot, State Inspector of Weights and Measures

Mr. Lightfoot reported that in several jurisdictions in his State there were local sealers of weights and measures and that the State official took charge of testing elsewhere. He gave figures showing the number of pieces of equipment inspected, tested, and condemned by the various local sealers and by the State department during 1933 and 1934.

\section{CALIFORNIA \&}

\section{By C. E. Tuckrr, Chief, State Division of Weights and Measures}

Mr. Tucker reported the growth of weights and measures work despite depressed conditions, and the harmonious conditions existing throughout the organization in the State. He also reported that the most important recent legislation enacted affecting the State department, was, that it had been made subject to civil service.

\section{CONNECTICUT}

\section{By Walter F. Stiles, Captain of State Police}

Mr. Stiles reported the passage of several laws strengthening weights and measures administration in the State; one changed the contents of the standard barrel from $31 \frac{1}{2}$ gallons to 31 gallons, to comply with the beer barrel adopted for Federal taxation purposes; other laws were in relation to the sale of gold by weight, and to the sale of gasoline and oils. A bill introduced to define a standard cord of wood failed of enactment.

2 For convenience of reference these reports have been arranged in alphabetical order throughout.

3 Submitted by mail and presented to the Conference by the secretary. 


\section{DISTRICT OF COLUMBIA}

(IMr. George M. Roberts, superintendent of weights, measures, and markets, District of Columbia, was not present at the meeting when the report for the District was called for. Mr. Walter C. Diller, chief inspector, presented Mr. Roberts' regrets.)

FLORIDA

\section{By N. Berryman, Assistant State Chemist}

Mr. Berryman reported that while the State had no weights and measures division, there was a growing interest in the subject. The only weights and measures work done by the State is the testing of gasoline pumps and the checking of the weight of food in package form. He reported activity on the part of some of the cities, but stated that the State had no official connection with this work.

\section{GEORGIA}

\section{By S. H. WILson, State Oil Chemist}

Mr. Wilson reported that some changes had been made in the weights and measures law at the last session of the legislature, but stated that it was not being enforced, since no money had been appropriated for this purpose. The main weights and measures work being done by the State consisted in the testing of gasoline pumps once every 90 days; there were local officials in several of the cities.

\section{ILLINOIS}

Ву Јонм J. Leviт, State Superintendent of Standards

Mr. Levitt reported upon the organization of the work in Illinois and the number of inspections made during the last year. $\mathrm{He}$ mentioned the problems involved in the coal-trucking situation and the steps taken to cope with this. He reported an increase in appropriation to purchase and operate equipment for the competent testing of large-capacity scales, and briefly described a survey indicating the necessity of such tests.

The Temporary Chairman. Now, gentlemen, I pray your indulgence for just a momemt. We want to hear from Mr. O'Keefe, the city inspector of weights and measures of Chicago.

\section{CHICAGO, ILLINOIS}

\section{By James O'Kenfe, City Inspector of Weights and Measures}

Mr. O'Keefe reported on the appropriations, tests, and prosecutions of the city department of weights and measures. He gave it as his opinion that calibration of capacities of vehicle tanks should be discontinued, and meters installed thereon. He also discussed the types of scales in use.

INDIANA

\section{By Martin L. Lang, State Commissioner of Weights and Measures}

Mr. Lang reported a steady gain in the number of inspections. made. He described the operation and benefits resulting from the corn loan law, which was administered by the State bureau of weights and measures, and also cited several other laws passed during the 
last 4 years. He reported that an additional unit for the testing of large-capacity scales was shortly to be purchased and put into service.

\section{KENTUCKY}

By William H. Ising, Jr., Chief Inspector of Weights and Measures, of Louisville

Mr. Ising stated that he was not prepared to make a report for the State, but reported that in the city of Louisville some trouble had been encountered in the regulation of the sale of coal brought in direct from the mine by truck, and that this matter was receiving special attention.

\section{MAINE}

Bу Jонм H. Austin, Deputy State Sealer of Weights and Measures

Mr. Austin reported upon new legislation recently adopted in the State, which included an act granting the right to manufacturers of milk bottles and oil cans to seal their product, with the right of test reserved to the officials, an act requiring the delivery of weight tickets with deliveries of coal; and an act granting the power to the State commissioner to make rules and regulations defining weights and measures.

MARYLAND

By S. T. Griffith, Chief, Division of Weights and Measures, of Baltimore

Mr. Griffith reported that while the State had a general weights and measures law there was no State department of weights and measures to enforce it and that few of the counties had sealers; he described the efforts being made to rectify this condition, and cited several amendments recently made in the State law. He stated that the city of Baltimore had a thorough organization and discussed some of the problems recently arising.

\section{MASSACHUSETTS}

By John P. McBride, Director, State Division of Siandards

Mr. McBride reported the procurement of new special apparatus, including portable equipment necessary for the proper test of vehicle tanks and a truck with power-operated crane for the adequate test of large-capacity scales. He also reported on the steps taken to cope with problems recently arising in connection with the sale of beer in barrels, of foodstuffs by the unit instead of by weight, and of fuel oil.

\section{MICHIGAN}

By Geo. S. Barnard, Director, State Bureau of Foods and Standards

Mr. Barnard reported on the organjzation of the inspection service and the cooperation between the State and local departments, giving statistics of work accomplished since the last Conference. He described the operation of special equipments designed for the test of large-capacity scales, and the plans being made for a special equipment for follow-up tests so that more of these tests could be accomplished. 


\section{MISSOURI}

By Lours G. Waldman, Commissioner of Weights and Measures, of St. Louis

Mr. Waldman reported that there was no State department of weights and measures but there were departments in a number of the larger cities. In St. Louis it was necessary strictly to regulate the very large amount of coal brought into the city direct from Illinois mines by truck, and the city received considerable revenue from this activity. He also noted new equipment installed for the test of vehicle tanks.

\section{NEW HAMPSHIRE}

By Walter G. White, State Commissioner of Weights and Measures

Mr. White reported difficulty experienced in the regulation of the increasing number of itinerant vendors selling by weight or measure; an effort to secure legislation involving registration, to deal with this class, had been unsuccessful. He reported, however, the passage of legislation requiring that all scales be located in full view of the customer, and mentioned a contemplated change in the law, requiring all commodities in package form to be marked with the correct net contents.

\section{ANNOUNCEMENTS}

(At this point announcements were made by the secretary that copies of the report of the committee on specifications and tolerances on person weighers were available for distribution; also the details of a radio broadcast by members of the Conference, on Tuesday evening, were given.)

(At this point, at $12: 58 \mathrm{p}$. m., the Conference took a recess until $2 \mathrm{p} . \mathrm{m}$.) 


\section{SECOND SESSION-AFTERNOON OF TUESDAY, JUNE 4, 1935}

(The Conference reassembled at 2:14 p. m., John P. McBride, temporary chairman, in the chair.)

\section{ABSTRACTS OF STATE REPORTS-Continued}

NEW JERSEY

By Joseph G. Rogers, Assistant State Superintendent of Weighis and Measures

Mr. Rogers reported on legislation and methods adopted to regulate the increasing number of coal deliveries being made direct from the mines by truck, on a new regulation for the sale of commodities by weight, and on developments resulting from the operation of codes, especially the petroleum code. He stated that as a result of depressed conditions, condemnations and prosecutions were on the increase. $\mathrm{He}$ also noted revival of interest in standard bread-weight legislation.

\section{NEW YORK}

By Alexander Hamilton, Deputy Commissioner, Department of Public Markets, Weights, and Measures, New York City

Mr. Hamilton stated that he was not prepared to report for the State, but reported that in New York City the mayor's bureau of weights and measures had been consolidated with the department of public markets. He described methods which had been adopted for raising revenue, especially the operation of a law requiring the registration of dealers in coal and licensing of weighmasters. He stated that as a result an adequate equipment for the test of large-capacity scales would shortly be procured.

\section{NORTH CAROLINA}

By C. D. BAuсом, State Superintendent of Weights and Measures

Mr. Baucom reported operations under the approval-of-type law, stating that of some 3,000 types of devices submitted, more than 1,000 had failed of approval. He mentioned that the calibration of tank trucks having large capacities was the most difficult feature of his work; that six new rules and regulations had been promulgated; and that a severe cut in appropriations made in 1933 had been partially restored.

\section{OHIO}

\section{By J. C. Trnkex, Deputy State Sealer}

Mr. Tinkey reported the issuance of a new book of instructions to sealers based on the specifications of the conference, but containing some additions, and urged uniformity of requirements throughout the country. Ho mentioned some features of the work which were in need of additional supervision and discussed the legislative program to strengthen the weights and measures laws, but stated that little has been accomplished in this connection. 
PENNSYLVANIA

By Urban E. Dice, County Sealer of Weights and Measures, Allegheny County

Mr. Dice reported that in the city of Pittsburgh the weights and measures department had been merged with the health department, that the county authorities now made tests in the city, but that the personnel of the department was inadequate for the work. He discussed a new coal law designed to regulate coal brought in from the mines by truck. He also reported that a new equipment for the test of large-capacity scales had just been put into use.

\section{VERMONT}

By H. N. Davis, Deputy State Commissioner of Weights and Measures

Mr. Davis reported that in Vermont weights and measures work was handled entirely by the State and that there had been great need of intensive work during the depression, but stated that he thought weights and measures conditions were better than formerly. He also reported the procurement of a new testing outfit for the calibration of vehicle tanks and for testing meters on tanks and at bulk plants, this replacing one the accuracy of which had been occasionally questioned.

\section{VIRGINIA}

\section{By J. H. MeEk, Director, State Division of Markets}

Mr. Meek reported that the work in the State had recently been extended, an increased number of jurisdictions now having weights and measures officials. He stated that the State law had been improved by amendments and that it was now similar to the model law; and that the State now tested large-capacity scales and gasoline devices in jurisdictions not having officials or lacking proper testing equipment, and also did general testing work for counties providing financial assistance.

\section{WEST VIRGINIA}

By P. J. Pellegrini, State Inspector of Weights and Measures

Mr. Pellegrini reported on the provisions of the weights and measures laws of the State and the manner in which these were being enforced. He noted an increased number of inspections made by the State department and a considerable increase in the number of pieces seized, and condemned for repair; also a special effort to prevent the sale of short-weight package goods. He stated that in the last 2 years the number of county sealers had decreased from 18 to 5 .

\section{WISCONSIN}

By Wilimam F. Steinel, Sealer of Weights and Measures, Milwaukee

Mr. Steinel reported that the Supreme Court of the State had handed down a decision that wrapped bread was not a container; therefore the attempt made to break down the standard-weight loaf provision by marking the weight on the wrapper of nonstandard-size loaves had been rendered unsuccessful. He described several activities outside the field of weights and measures which had been assigned to the department of weights and measures. 


\section{WYOMING 4}

\section{By Arling Gardner, Deputy Commissioner of Agriculture}

Mr. Gardner reported on the enforcement of the weights and measures law, stating that some types of devices were regularly tested twice a year; however, others, such as coal scales and vehicle tanks, were tested only upon request, while still others, including most largecapacity scales, were not tested at all on account of lack of personnel and equipment, a condition in need of remedy. He noted that products sold by weight and measure were systematically checked.

\section{ABSTRACTS OF REPORTS OF REPRESENTATIVES OF STATE ASSOCIATIONS OF WEIGHTS AND MEASURES OFFICIALS ${ }^{\circ}$}

INDIANA ASSOCIATION OF INSPECTORS OF WEIGHTS AND MEASURES

By Rolinn E. MeEk, Chief State Inspector of Weights and Measures

Mir. Meek reported, as president of the association, that the association had just held its twenty-third annual conference, and mentioned some of the features of the meeting. He stated that it cooperated to the fullest extent with the State bureau and that this cooperation had resulted in better weights and measures administration.

\section{MAINE STATE SEALERS' ASSOCIATION}

By James A. Boyle, Sealer of Weights and Measures, Portland

Mr. Boyle reported, as secretary of the association, on the legislative program and the administration of weights and measures in the State. He reported the passage of one law authorizing the State sealer to promulgate rules and regulations. He described the apparatus and methods employed in the test of vehicle tanks, and advocated publicity in connection with prosecutions for violations of law.

\section{MASSACHUSETTS ASSOCIATION OF SEALERS OF WEIGHTS AND MEASURES}

By E. M. BeEbe, Deputy Sealer of Weights and Measures, Springfield

Mr. Beebe reported, as official delegate to the National Conference, that the State association was formed in 1926, and now had a membership of 365 . He stated that the association was a strong advocate of civil service, and also interested itself in improvement of the State law, being influential with the legislature in this regard. He discussed the provisions of some new laws and regulations. He paid $\mathbf{a}$ tribute to Mr. Fred E. Marsh, sealer of Ware, who is serving his fiftieth year in office.

\section{MICHIGAN ASSOCIATION OF WEIGHTS AND MEASURES OFFICIALS}

By Irving G. Wheeler, Sealer of Weights ana Measures, Jackson County

Mr. Wheeler reported, as president of the association, that the association was sponsoring a survey of the standards and weights and measures conditions in the State, and it was hoped that this project would shortly be completed. It was believed that the facts developed in this survey would result in securing a greater uniformity in the solution of weights and measures problems arising.

\footnotetext{
1 Submitted by mail and presented to the Conference by the secretary.

- For convenience of reference these reports have been arranged in alphabetical order.
} 
NEW JERSEY WEIGHTS AND MEASURES ASSOCIATION

By Joseph G. Rogers, Assistant State Superintendent of Weights and Measures

Mr. Rogers reported, as secretary of the association, that during the period that the National Conference suspended its meetings the State association also suspended its regular annual conferences and substituted a 1-day meeting each year. He stated that this year a 2-day meeting would be held; thereafter it was expected that the regular conferences would be resumed.

\section{OHIO SEALERS' ASSOCIATION}

By C. R. McFAdDen, Sealer of Weights and Measures, Licking County

Mr. McFadden, as president of the association, reported the manner in which the association functioned; one general annual meeting is held, and in addition district meetings are held in various parts of the State, particular attention being given to the instruction of new sealers; recently a large number of officials have been appointed. $\mathrm{He}$ stated that great improvement of conditions had been made, at small cost to the public.

(At this point, Mr. B. W. Ragland, chief, bureau of weights and measures, Richmond, Va., and Mr. Howard E. Crawford, inspector of weights and measures, Jacksonville, Fla., were called upon and spoke briefly in relation to conditions in their jurisdictions.)

Mr. Bundenthal. Mr. Chairman, no action has been taken on a very splendid suggestion made by Mr. Beebe. I refer to his remarks concerning the weights and measures official who just completed 50 years of activity as a weights and measures worker, Mr. Fred E. Marsh, of Ware, Mass. I think that record is due some recognition by this National Conference. I move that the secretary be instructed to write a letter expressing the felicitations of the Conference upon his splendid service.

(The motion was seconded, the question was taken, and the motion was agreed to.)

\section{ELECTION OF PRESIDING OFFICER FOR 1935 MEETING}

The Temporary Chairman. We will now proceed to the first order of the afternoon session, item 5 on the program, the election of a presiding officer for the 1935 meeting. Your choice will continue, where I now leave off, for the balance of the Conference.

Mr. Waldman. I nominate Mr. McBride, of Massachusetts, our temporary chairman, as presiding officer for the 1935 meeting.

(At this point the secretary assumed the chair.)

(The nomination was seconded.)

The Acting Chairman. Are there any other nominations?

(It was moved and seconded that the nominations be closed, and that the secretary be directed to cast the ballot of the Conference for the nominee for presiding officer for the 1935 meeting.)

(Accordingly, the secretary cast the ballot of the Conference for the presiding officer for the 1935 meeting, as nominated, and he was declared duly elected.)

(At this point, Mr. John P. McBride resumed the chair.)

The Chairman. Thank you, gentlemen.

At this point on the program, it was intended that representatives of manufacturers of person weighers should demonstrate their products to the Conference. In relation to this item, I may state that all 
known manufacturers of these devices were invited to exhibit but none have taken advantage of this invitation.

In the lack of exhibits, the representatives of manufacturers of person weighers will be given a brief opportunity to address the Conference in relation to person weighers. We would like to hear general statements as to how the inspection of person weighers under the code of specifications and tolerances proposed would affect the various products.

(SeCRETARy's Note.-In response to the above invitation, Mr. W. G. Fitzgerald addressed the Conference. Since his remarks referred wholly to specification 9, for person weighers, they have been included later in the report when this specification came up for general discussion.)

REPORT OF COMMITTEE ON SPECIFICATIONS AND TOLERANCES ON SPECIFICATIONS, TOLERANCES, AND REGULATIONS FOR PERSON WEIGHERS, PRESENTED BY F.S. HOLBROOK, CHAIRMAN

Mr. Chairman and gentlemen, your committee on specifications and tolerances has given consideration to the code of specifications, tolerances, and regulations for person weighers, which was tentatively adopted by the twenty-fourth national conference in 1931. At the time of its tentative adoption it was presumed that it would come up for action before this body in 1932. However, due to the cancelation of several conferences, its further consideration has now been postponed for 3 years. During this pericd it has continued to remain in a tentative status, insofar as the National Conference on Weights and Measures and the National Bureau of Standards are concerned.

Your committee now recommends several changes in the code, and also makes recommendations in regard to the paragraphs of the specifications which it is believed should be retroactive and nonretroactive, respectively. In the mimeographed code, underlining indicates nonretroactive material. ${ }^{6}$

Your committee recommends that specifications 3 and 11 of the tentative code for person weighers as adopted in 1931, be amended in the manner which will be pointed out; that a new specification to be numbered 8 be added; and that specifications 2 and 5 be made nonretroactive.

Respectfully submitted.

(Signed) F. S. HоLвRоок, Chairman,

Joseph G. ROGERS,

John P. McBride,

Geo. F. Austin, Jr.,

Committee on Specifications and Tolerances.

DISCUSSION OF ABOVE REPORT

Mr. HolвRоок. The code will now be read, paragraph by paragraph. I hope you gentlemen will interrupt at any time when there is any question in your minds concerning any specification.

It may be well, at this time, to call attention to the fact that officials, manufacturers, or owners or users of these machines have the privilege

- Italic type is used herein to indicate nonretroactive material. 
of the floor. However, it is the practice of the Conference that officials only shall vote on any question that arises. [Reading:]

Note.-The following specifications, tolerances, and regulations shall apply to person weighers in those cases in which they are used or to be used commercially-that is, when a charge is made for the weighing service-and such use shall be permitted only when the provisions of this code are complied with. Whenever noncommercial person weighers are inspected and tested by the weights and measures official, it is recommended that these be officially sealed only when they comply with these specifications and tolerances.

\section{DEFINITIONS}

A person weigher is a scale of any type which is specially designed for the weighing of persons. This definition is not to be construed to include scales specifically designed for the weighing of infants and children.

A "beam" person weigher is one in which weight indications are obtained by the manipulation of one or more beam poises.

An "automatic-indicating" person weigher is one in which weights are automatically indicated on a reading face of any type.

A "ticket" person weigher is one in which a representation of each individual weight is automatically made upon a ticket, card, etc., which is automatically delivered to a suitable receptacle on the outside of the scale.

\section{SPECIFICATIONS}

1. A person weigher shall have a capacity of not less than 250 pounds.

2. A person weigher shall be so designed and constructed that it has a definite and clear zero graduation and gives a definite and clear indication of its zero balance condition at all times when ready for use. In the case of an automatic-indicating or ticket person weigher the zone throughout which the zero balance condition shall be indicated shall correspond to at least 5 pounds on each side of the zero graduation.

I think it is only fair to call your attention, in the case of this specification, to the fact that it represents a departure from former conventional construction; this type of person weigher has come upon the market only in the last few years, largely, I think, as a result of this requirement. You will readily recognize that a great many machines now in use do not, at the present time, comply with that specification. For these reasons it is believed, that if the specification is adopted, it should be made nonretroactive. ${ }^{7}$

3. A person weigher shall be so designed and constructed that it is susceptible of giving weight indications at all points between zero and capacity: Provided, however, That a person weigher may have an interval between zero and some definite weight value throughout which weight values are not given, but in this case the person weigher shall be so designed and constructed that whenever the weight on the platform is such as to fall within this interval, any coin inserted will be returned to the user through automatic delivery to a suitable receptable on the outside of the person weigher, or the insertion of a coin in the coin slot will automatically be prevented.

The last clause is new. It is recommended that it be added to the specification at this time.

4. The maximum value of the minimum weight graduations on any person weigher shall be 1 pound.

5. A person weigher whose weight indication is changed by an amount greater than one-half the tolerance allowed, when set in any position on a surface making an angle of 5 percent or approximately $3^{\circ}$ with the horizontal, shall be equipped with a device which will indicate when the person weigher is level, and in no case shall any pendulum operating the person weigher be considered a leveling device. The person weigher shall be rebalanced at zero each time its position is altered during the test contemplated by this specification.

6. All devices for adjusting the balance condition or the level of a person weigher shall be of such construction that they are operative or accessible only by the use

\footnotetext{
7 For general discussion of this specification see p. 20.
} 
of some tool or device which is outside of and entirely separate from the device in question, such as a screw driver, wrench, etc., but not an adjusting pin.

7. A person weigher which is liable to give incorrect results except when special precautions are observed shall have appropriate and explicit instructions conspicuously, clearly, and permanently marked upon it.

Mr. Baucom. Mr. Holbrook, is that necessary in there? Just for argument, if the thing doesn't do the work, why approve it at all? I haven't time to study it all, but my first reaction is that specification 7 is hardly needed.

Mr. Houbrook. Take the case of a ticket person weigher; this type of scale stamps a weight upon a card. If a person should drop his penny after he steps upon the scale, before the vibrating mechanism has come to rest, he may get an incorrect weight. A sign "Stand Still Before Depositing Coin", would seem reasonable and appropriate.

Mr. Fitzgerald. Mr. Chairman, we have a "delay coin shutter", so that the person can step on the scale and drop the coin, but the machine will not operate until the dial has come to rest. On that scale such instructions are not necessary.

Mr. HouBrook. I cited that as an example of the instruction that might be put on the scale.

8. A person weigher shall be so designed and constructed as to facilitate the affixing by the weights and measures official of a condemning tag by means of a wire in such a way that the insertion of a coin in the coin slot will be prevented when the device is under condemnation.

This is a paragraph recommended by the committee for addition to the code. The committee is of the opinion that persons desirous of obtaining their weight may be liable to overlook a condemning tag on a scale and use the scale in spite of this tag if the coin slot is still open for the reception of coins.

A very slight modification would be to have a coin slot with two drilled holes on either side opposite each other so that in affixing the condemning tag the inspector can draw his wire across the coin slot. This would be an unmistakable notice to the public that the scale was not in proper condition for use.

Mr. Losey. Could that specification be amended before we vote on this? We person-weigher men desire to know how the devices will be modified to accommodate the wire. Is the wire to be inserted during the time it is condemned until a man comes and makes repairs? In my community we have experienced considerable difficulty all the way between the time a machine was condemned and the time the repairman comes to make the proper adjustment.

Mr. Holbrook. As a committee we do not feel entitled to bring a new recommendation before this Conference this year, and move that it be retroactively adopted in relation to all machines which are on the streets at the present time. Some of these machines could be readily made to comply with this specification by the drilling of two holes. However, I am advised that this operation would damage the appearance of some machines. Again, the enamel might be broken and render that portion of the scale which had been drilled subject to rapid deterioration. We feel this is an excellent thing in general, but we are not prepared to recommend it for immediate enforcement against machines already sold and in use. We think it a reasonable requirement for scales hereafter produced by manufacturers.

Mr. Ragland. Couldn't it be amended to require that machines now out be taken back to their establishments for repair? 
Mr. HoLBRook. I think such a thing as that would normally be a local regulation. I do not know how such a thing could be handled as part of a Conference code. Something of that sort might be done, but that certainly would not be a requirement to be imposed upon the manufacturer, because the manufacturer has often disposed of these machines, and is no longer responsible. The owner is the man who would have to take care of any modification of that kind.

$\mathrm{Mr}$. BAUCom. Could we legally enforce such a requirement contrary to this adoption here today?

Mr. Holbrook. If you have powers to make local rules and regulations governing the use of devices, I presume that such a local requirement would stand in the courts.

Mr. Rogers. Mr. Chairman, in the State of New Jersey local jurisdictions would never do that themselves. Such a regulation would have to come through the State superintendent of weights and measures.

Mr. Davis. Does this contemplate a place to insert the wire of a lead seal on the scale, or a condemnation tag?

Mr. Hоцвгоок. This relates only to attaching a condemning tag. It has been suggested when an official tags a person-weigher scale as condemned, the public may go on using it, overlooking the condemning tag. You see, there is a difference between the ordinary commercial scale and the person weigher. When a commercial scale is condemned, it becomes illegal for the owner to use it, and if he does so, he is liable to punishment. However, when you have these person weighers out on location, the owners are not present. It is not the owner, but the public, who is the user. Therefore the ordinary penalty for the use of condemned equipment does not apply.

To meet this situation the method suggested would make it impossible for the public to overlook the condemning tag, since it would effectively prevent the insertion of the coin. It is very good notice that the device is not in condition for use.

Mr. Davis. My question was as to whether the manufacturer should provide a hole in that machine to facilitate the attachment of a seal or condemning tag. These scales have no place provided for this. It becomes necessary to stick on a paper sticker, and especially if a scale is outside exposed to rain or snow, it will not remain attached.

My thought was to have the scale so constructed that a place would be provided for wiring on a condemning tag or a lead seal.

Mr. HolbRook. That subject has been raised from time to time in the past, and it has been suggested that the various jurisdictions use so many different types of seals that it is difficult for the manufacturer to determine what character of seal is going to be used. He must know this if he is to make proper provision for it. As I recall it, many years ago, perhaps in 1913, Mr. Charles C. Neale, then of Minnesota, brought down a very elaborate collection of seals of various types and made recommendations for the adoption of a more or less uniform seal. He may have coupled with that a request that the manufacturers then provide a place to which that uniform seal could readily be attached, or affixed. However, the uniform seal never materialized, and the manufacturer is still in doubt as to what character of sealing means he should provide. At any rate, I think but few of the commercial machines on the market at the present time provide any special place or means for the attachment of a seal. 
Mr. Tinkey. I believe there is one point that has been overlooked. Suppose you pass this regulation? I drive my car 20 to 200 miles in my trips, and I put a condemning tag on a person weigher. The next day the repairman of the manufacturer may come along. He cannot do any work on it before that condemning tag is off. He has got to call me back in order to take that tag off. If a customer puts a penny in a scale that is tagged as condemned, he ought to lose the penny. It looks to me to be superfluous.

Mr. Holbrook. I believe, Mr. Tinkey, that the repairman does not have to wait for the sealer before he can repair the scale. $\mathrm{He}$ has access to the mechanism, and does not have to drop coins in the slot to test and adjust it. I believe he can get into that machine so as to adjust and make necessary repairs with perfect freedom.

9. A ticket person weigher shall be so designed and constructed that throughout a period when the supply of tickets is exhausted, any coin which is inserted will be returned to the user through automatic delivery to a suitable receptacle on the outside of the person weigher, or the insertion of a coin in the coin slot will automatically be prevented.

Mr. Fitzgerald. Mr. Chairman, and gentlemen of the Conference, I represent the International Ticket Scale Corporation. Since specification 9 affects the company I represent, I would like to make an explanation on that point. This requires that throughout a period when the supply of tickets is exhausted, any coin which is inserted will be returned to the user through automatic delivery to a suitable receptacle on the outside of the person weigher, or the insertion of a coin in the coin slot will automatically be prevented. Now our scale, while it is susceptible to that construction, is not so constructed except in the State of Massachusetts, where you now have that regulation. The scales throughout the counties in the various States do not have that device on them. However, the danger is remote by reason of the fact that the scale has a supply of 10,000 tickets, and thus there is little chance of the scale running out of tickets.

Moreover, in all the localities the scales are under the direct supervision of employees practically all the time. Not only is there only a very small chance of the scale running out of tickets, but if by any chance this should occur the customer is in a position to get a refund, and we are always willing to make refunds.

Therefore, we respectfully ask that specification 9 be made nonretroactive, for scales out on location. When the equipment comes into the factory for reconditioning we would have that change made.

That is the only item in the code that causes us any concern. As far as the rest of it is concerned we are quite willing to follow all the requirements.

Mr. Holbrook. In relation to specification 9 about which $\mathrm{Mr}$. Fitzgerald has just spoken, I may say that the committee did not have a request from any manufacturer to the effect that that be made nonretroactive; it has not been so recommended. However, it seems that if there are many ticket person weighers on the market or in the field at the present time, which cannot easily be modified, there may be some merit in that request. The general necessity of the specification, however, I think is undoubted. It would be unfair in general to have a machine upon the streets for the reception of a coin when 
no service could be performed by the scale, as would be the case when the tickets were exhausted.

Does Mr. Fitzgerald's request impress any of you so much that you desire to make a motion that this specification be made nonretroactive? If so, it would be well to have it presented so that we can act on it.

Mr. O'KeEFe. I move that specification 9 be made nonretroactive.

Mr. Losey. I believe it would be very unfair to make it retroactive. These ticket weighers are in use in Baltimore, and they are pretty well taken care of.

Mr. BAUCOM. I would like to have my memory refreshed as to just how soon these recommendations go into effect after adoption by this Conference. Immediately upon adoption here, they automatically become law in my State. If you want to set a future date, we might compromise, but I want to know when it goes into effect.

Mr. Holbrook. So far as the National Conference is concerned, after the tentative adoption, the code is laid upon the table, usually for 1 year. Upon final adoption the code is presumed to take force and effect at once. However, as a practical matter it may be said that the date of taking effect in any State is usually the date of promulgation of the specification in that State. As you know, in general cases, the adoption of a code of specifications and tolerances here, has no legal force and effect in and of itself. It must needs be adopted in any particular jurisdiction desiring to enforce it.

Mr. O'KeEFE. It goes into effect upon the date when we notify manufacturers to comply. They are then to manufacture machines under these specifications.

The Chalrman. The date of adoption is as fixed in the various jurisdictions.

Mr. A. F. Barnard. Mr. Chairman, it seems that in a number of communities this specification will be adopted when passed by the Conference. In relation to specification 9 , I presume we should first accept the specification, and then make it nonretroactive. I would amend the motion accordingly.

Mr. Griffith. Mr. Chairman, it might be well to complete the reading by the secretary and then come back for action on this point.

The Chairman. I think that a good suggestion, if Mr. O'Keefe will withdraw his motion.

Mr. O'KeEFE. I will withdraw my motion.

The Charrman. No action will be taken by the Conference on this matter until we get through the specifications. ${ }^{8}$

Mr. HoLBRook. In order to straighten out this question of procedure, I will try to make our usual practice plain. The method we have usually adopted was to have the specification read paragraph by paragraph, and comment invited. That is why I paused after reading each specification. Usually if this comment developed the desire of the Conference to amend, the amendment was made at once. After the reading was done the code was voted on as a whole and adopted as amended. However, as that method has not been understood, the only fair way is to complete the reading of the code.

10. A ticket person weigher shall be so designed and constructed that the printing, stamping, or transferring of the weight record on the ticket will not occur

1 For final action of the Conference on specification 9, see p. 49. 
until the weighing mechanism has had ample opportunity to come to rest, under normal person weighing conditions.

11. A ticket person weigher shall be so designed and constructed that it is susceptible of giving a clear, distinct, and definite statement or representation of weight on the weight ticket: Provided, however, That if there is an interval between zero and a definite weight value throughout which tickets are not given, then the coin shall be returned or the insertion of a coin in the coin slot shall automatically be prevented, as provided in specification 3, or the weight value shall be indicated on a dial or reading face.

This specification shall be construed to require that the specifications contained in this code and the specifications for automatic-indicating scales, relative to weight indicators, weight graduations, clear intervals between weight graduations, etc., shall apply to the representations of weight made by a ticket person weigher, when this representation is such as to make these requirements applicable. These requirements shall be broadly applied to appropriate portions of the said representations so as to require the same degree of clearness, definiteness, precision of reading, etc., in the case of both ticket and automatic-indicating person weighers.

That proviso in the first paragraph is recommended by the committee for the first time this year. The remainder of the specification is as formerly adopted.

12. When not modified by the requirements of this code the specifications given under the heading "Scales-General Specifications", "Platform Scales", and "Automatic-Indicating Scales" shall apply to person weighers insofar as they are applicable.

\section{SENSIBILITY RECIPROCAL (SR)}

The maximum SR allowable on beam person weighers shall be the value of two of the minimum graduations on the beam, at the capacity or at any lesser load: Provided, however, That the manufacturers' maximum SR or the maximum SR on all new beam person weighers shall be the value of one of the minimum graduations on the beam, at the capacity or at any lesser load.

\section{TOLERANCES}

The tolerances to be allowed in excess or deficiency on beam person weighers shall be those specified under the heading "Platform Scales." The tolerances to be allowed in excess or deficiency on automatic-indicating and ticket person weighers shall be those specified under the heading "Large-Capacity AutomaticIndicating Scales."

\section{REGULATIONS}

1. A person weigher shall be maintained in level.

2 A ticket person weigher shall be so maintained in use that all statements or reprnsentations of weight printed, stamped, or otherwise transferred on or to the weight ticket during operation shall be clear and distinct.

3. A person weigher shall be permanently and legibly marked with a statement containing the name and address of the person, firm, or corporation responsible for placing the person weigher in service, in combination with some such words as "Operated by", "Maintained by", etc.: Provided, however, That such statement shall not be required when the person weigher is in service on the premises of such person, firm, or corporation.

Mr. Levitr. Mr. Chairman, I imagine everybody is aware that the matters in the specification have been brought out on account of certain types of manufacture. I wonder if it wouldn't clarify the entire specification to make it effective at a later date, say July 1, 1936. That would give every manufacturer sufficient time to bring his equipment up to par, and would give the States time to adopt and to put into effect these rules and regulations. No manufacturer can then say he did not have proper notice.

Mr. Houbrook. On July 1, 1936, then, we would have to meet the question as to which specifications shall be retroactive and which shall be nonretroactive, because on that date we are still going to 
have many thousands of person weighers in use which do not comply with some of the sections of this code. Are all machines to be required to comply with all the provisions of this code as of July 1, 1936?

Mr. LEVITT. I stated the matter from a State sealer's standpoint. Of course, manufacturers putting out scales naturally would try to put out equipment that wouldn't be condemned at a later date.

Mr. Griffith. Mr. Levitt may not be familiar with the fact that in 1931 this Conference adopted tentatively all these regulations and specifications with the exception of those few new items recommended by the committee at this meeting. The manufacturers of personweigher scales have been put on notice as to the requirements for construction of their several devices. As a matter of fact, the manufacturers are now making their scales as required by these specifications. The difficulty we are confronted with, in my experience, is from the old scales which are already in use.

For your information, these requirements were adopted in 1931. They were the only guide we had in Baltimore. Immediately upon their adoption our office notified all per'son weigher people of record in our office that beginning in 1932 we would enforce these regulations. At the beginning of 1932 we started to enforce these regulations, not rigidly, but generally. Where scales did not conform, we endeavored to get the manufacturer, or operator, to make them conform.

During all the time that has elapsed from 1931 to 1935, those concerns have been on notice as to the requirements. If you are going to make them effective as of 1936, you are going to have the same question arise on that date as to what scales are going to be affected by the regulations, and what are not. That matter ought to be decided by this Conference. I believe the committee is warranted in making the required changes, and that they are necessary changes.

Mr. DAvis. I want to say the commissioner of weights and measures of Vermont promulgated regulations putting those regulations which were adopted by the Conference in 1931, in force in 1933. They were made nonretroactive as to every scale that was in operation in the State before that time. Any scale that came in after that time was supposed to conform with these regulations.

Mr. RAGLAND. Mr. Chairman, I am vitally interested in this proposition, because Richmond has an ordinance which states that the code of the city of Richmond is the same as the code adopted by the National Conference on Weights and Measures. I now desire to discuss specification 2.

The Chairman. I am going to ask Mr. Holbrook to outline specification 2 again.

Mr. Holbrook. Specification 2 reads as follows:

2. A person weigher shall be so designed and constructed that it has a definite and clear zero graduation and gives a definite and clear indication of its zero balance condition at all times when ready for use. In the case of an automatic-indicating or ticket person weigher the zone throughout which the zero balance condition shall be indicated shall correspond to at least 5 pounds on each side of the zero graduation.

Mr. RAGLAND. It is foolishness to put that second section in the code. I think we ought to eliminate it.

Mr. Bowling. Mr. Chairman, with reference to specification 2, speaking to this Conference on behalf of the operators of scales, I believe it is hard for anyone, either the public, the men in this business 
service, or the Conference, to say definitely what the public desires. I have here a letter which I received today, which clearly shows the effect that section 2 has upon the earning capacity of scales, and the earning capacity naturally reflects the opinion of the public. This letter is from the general manager of the Welfare and Recreation Association, operating in the public buildings and grounds of the Federal Government, Mr. F. W. Hoover.

Mr. Edward E. Bowling,

JUNE 4, 1935.

3915 Barrington Road, Baltimore, Md.:

Dear Mr. Bowling: During the month of March 1934 this association purchased a weighing machine with a free zero and placed it right alongside a machine of a similar type without the free zero, in the United States Department of Commerce Building, to determine whether there would be any preference on the part of the public between the two machines.

Since March 1, 1934, when the weigher with the free zero, which will be referred to as the new machine, was installed, the machine without the free zero has taken in in excess of 120 percent more than has the new machine.

It is believed that this test is an excellent one because the weighing machines are approximately the same size and equally attractive, and are side by side at the exit from the main dining room of the Commerce cafeteria.

Very truly yours,

(Signed) F. W. Hoover

General Manager.

Now I ask you to become familiar with this free-zero scale before removing these other machines. Here is an example of a scale in use 13 months-people coming in daily contact with it. It is clearly demonstrated that the machine without the free zero has taken in 120 percent more than the other machine. A corresponding decrease in revenue from my machines would result in making my entire investment absolutely valueless.

Mr. Losey. I operate about 400 person weighers in Washington and Baltimore, and when they were modified to have free zeros, the income from them dropped off approximately 50 percent. We will lose our entire investment by having a free zero on our scales.

Mr. Ragland. Mr. Chairman, I move that specification 2 be stricken.

(The motion was seconded.)

Mr. Griffith. It seems to me that this deserves a lot of consideration. As Mr. Bowling and Mr. Losey have said, they are interested. These gentlemen are from my city. In general, no matter what type of scale you are using, you have to know whether it is balanced at zero before you can say whether it is in proper weighing condition. There are a number of scale manufacturers here. I would like to ask them, as well as the sealers of weights and measures, if they can tell us when a scale is in proper balance if it is locked at the zero point. Certainly, unless the scale is so constructed that the beam or indicator will oscillate and come to rest at zero, you don't know whether it is in proper balance.

This section 2 requires the construction of the device to be such that you, as sealers of weights and measures, who are responsible for the accuracy of the device in use, know whether it is in correct balance. Unless you have a means of determining whether or not it is in zero balance, you cannot safely pass the scale. The facts that Mr. Bowling mentioned about the public-buildings scale indicates that there may be prejudice against a scale that oscillates. On the other 
hand such a scale has a good deal of merit. How to solve that problem I do not know. I am not so much troubled with this question as I am in seeing a machine in accurate calibration throughout its capacity.

I think the specification should be maintained. Person weighers should conform to the general specifications that are applied to all legal scales.

Mr. Ragland. Mr. Holbrook, do our present codes require that all kinds of scales have a clear and distinct zero reading?

Mr. Holbroor. Yes, that is right.

Mr. RagLAND. That is why it is my thought to eliminate this. All scales, whether person weighers or not, should have a clear zero, not a floating zero.

Mr. Holbrook. The person-weigher scales which you see on the street at the present time, do have, it is true, a zero indication, but in the case of the large majority of them, the zero indication means nothing. Such scales are locked at zero; they can indicate nothing else when not in use. No matter how badly the scale goes out of balance, the zero indication is always maintained.

The purpose of this paragraph is to provide that the scale shall not be locked at the zero point; it requires that the scale disclose its balance condition. The older scales cannot do this at the present time, the indicator to the contrary regardless.

Mr. RaGland. I have found many, many scales that were in balance, yet when I put a 50-pound weight on them, I find out there is something wrong.

Mr. Chairman, I will compromise. I amend my motion to provide that we strike out the second sentence only.

Mr. Griffith. That means that we will have the oscillating free zero, and no more locked zeros; but the second sentence is explanatory of that. The part eliminated is the guide to determine the whole thing.

Mr. O'Kenfe. Mr. Chairman, we have been here since 10 o'clock this morning, and now it is 5 o'clock. After working so long on this matter, I think it would be a good thing for us all to go home and think these things over. It won't take very long in the morning to decide this matter. I move you that we adjourn.

(The motion was seconded.)

Mr. Griphith. I am perfectly willing to concede to that, but I think we should give some consideration to the person-weigher men. There are 3 or 4 from Baltimore here today, and I don't know whether it is convenient for them to be here tomorrow. In deference to them, I think we ought to complete this matter today.

The Chairman. Is there any objection on the part of the personweigher men to deferring action on this question until tomorrow morning?

Mr. Bowling. Personally, I would like to see it cleared up tonight. Of course, I don't want to go contrary to your wishes.

The Chairman. It is moved and seconded that the Conference adjourn until tomorrow morning.

Mr. Ragland. I don't want the thing put off until tomorrow. I am opposed to that motion.

(The question was taken, and the motion was agreed to.)

(Thereupon, at 5:05 p. m., the Conference adjourned to meet at $10 \mathrm{a} . \mathrm{m}$., Wednesday, June 5, 1935.) 


\section{THIRD SESSION-MORNING OF WEDNESDAY, JUNE 5, 1935}

(The Conference reassembled at 10:16 a. m., at the National Bureau of Standards, Mr. John P. McBride, presiding officer, in the chair.)

\section{ANNOUNCEMENT, AND APPOINTMENT OF SPECIAL COMMITTEE OIN RESOLUTIONS}

The Chairmax. Gentlemen, my first duty here this morning is a very sad one. I have to report to the conference that Mr. John H. Austin, deputy State sealer of weights and measures, of Maine, met with accidental death last night. Apparently he was walking in his sleep, he fell from a window, and it is now announced that he is dead.

I am ready for any suggestions that the Conference may offer. The thought of the chair is that we might appoint a special committee on resolutions, out of regular order, to report a resolution as soon as may be.

Mr. Engelhard. Mr. Chairman, I move you that the chair appoint a special resolutions committee to draw appropriate resolutions regarding the death of Mr. Austin, these to be spread upon our records here, and also sent to his family and to the authorities of the jurisdiction from which he comes. to.)

(The motion was seconded, the question was taken, and the motion was agreed

The Charrman. Gentlemen, I will appoint that committee at once.

Mr. James Boyle, city sealer of weights and measures, Portland, Maine, Mr. Walter G. White, State commissioner of weights and measures, Concord, N. H., and Mr. Glenn L. Berry, county superintendent of weights and measures, Asbury Park, N.J.

\section{FEDERAL SPECIFICATION AAA-S-121 FOR WEIGHING SCALES}

By RAlph W. Smith, National Bureau of Standards

Federal specification AAA-S-121 for weighing scales is one of a large number of Federal specifications developed and promulgated primarily for use in connection with Federal procurement projects. These Federal specifications cover a very wide field. They range all the way from acetone to zinc oxide, from adzes to wrenches, from artillery to wheel barrows, from asparagus to yeast.

These specifications are purchase requirements and embody technical specifications for the subject material, methods of inspection and test, and packaging, packing, and marking requirements. Their preparation rests with a group of technical committees, each committee dealing with a closely related group of specifications. The work of the committees is directed and coordinated by a single body which, until early in 1935, has been the Federal Specifications Board.

The Federal Specifications Board was organized under the authority of Circular 42, of the Bureau of the Budget, dated October 10, 1921. The duty of this Board was "to compile and adopt standard 
specifications for materials and service, and to bring specifications into harmony with the best commercial practices wherever conditions permit." It was ordered that the Director of the National Bureau of Standards should be ex-officio chairman of the Board, and the Board was to function under the general direction of the Chief Coordinator for General Supply, an officer of the Bureau of the Budget. The circular further stated that "the specifications that are prepared, adopted by the Board, and approved by the Director of the National Bureau of Standards shall, as far as applicable, be binding upon and govern all departments, bureaus, agencies, and offices of the Government."

By the terms of Executive Order 6166 of the President of the United States, dated June 10, 1933, there was created a Procurement Division in the United States Treasury Department, headed by a Director of Procurement. This order stated that "in respect of any kind of procurement, warehousing, or distribution for any agency", the Procurement Division might undertake the performance of such procurement, warehousing, or distribution, or might entrust such performance to other agencies. Under an order of the Secretary of the Treasury approved by the President of the United States on October 9, 1933, the functions of the Federal Specifications Board were transferred to the Procurement Division; the Board continued, however, to function as a distinct body, much as before, the regulations prescribing that " under the direction of the Director of Procurement, the Federal Specifications Board will prepare purchase specifications for supplies used by the several executive departments, with due regard to available commercial types, grades, and sizes." However, these regulations introduced one important modification of procedure, this being a liberalization of the former rule that Federal specifications were binding in the case of all Federal purchases. The new regulation reads as follows:

If any Executive Department finds that for administrative reasons a Federal specification cannot be used to meet its particular or essential needs, it is authorized to use its own purchase specification, but such specification shall include all applicable provisions of the Federal specification, and in those cases where the purchase exceeds $\$ 1,000$ a report shall be made to the Procurement Division, Branch of Supplies, showing the necessity for deviation from the Federal specification.

On January 24, 1935, the Federal Specifications Board was abolished; this was accomplished by an order of the National Emergency Council, a group headed by the President of the United States. The business of the Board could not immediately be concluded, however, and it was not until May 7 that the final meeting was held and the Federal Specifications Board actually disbanded. The best information available at the present time is that the work formerly done by the Federal Specifications Board will be continued by a Federal Specification Section of the Procurement Division, under the direct charge of an officer to be known as the Technical Assistant to the Assistant Director of Procurement. In lieu of the members constituting the old Federal Specifications Board, there are now being appointed technical liaison representatives, from each executive department and independent establishment of the Government. It is anticipated that the technical committees will continue to function as in the past and that the specifications promulgated will continue to be known as Federal specifications. 
Concluding this brief outline of the history of the Federal Specifications Board, I may say that later on the program of this Conference, a number of general aspects of Federal specifications, with particular reference to the consumer, will be discussed by Dr. A. S. McAllister.

The technical committee responsible for the development of Federal specification AAA-S-121 is the Committee on Commercial Weighing and Measuring Devices, of which Mr. F. S. Ho brook is the chairman, and your speaker the secretary. The first meeting of this committee was held on December 1, 1924. Meetings of the committee have been held at irregular intervals since that time as various matters came before it for consideration. Federal specifications have been developed by this committee on four items: Railway track scales, liquid-measuring devices, stop watches, and a general specification for scales, the latter being now designated specification AAA-S-121. Work is almost completed on a specification for prescription scales and weights. The specification for railway track scales includes as its technical requirements the provisions of Bureau of Standards Circular C83, the well-known "Specifications for the Manufacture and Installation of Railroad Track Scales." The Federal specification on liquid-measuring devices closely follows, in its technical requirements, the code of specifications and tolerances for liquidmeasuring devices of the National Conference on Weights and Measures. There was no existing specification on stop watches, and the Federal specification for this item naturally consists of new material.

The general specification for scales as originally developed embraced only very general requirements, closely following the general specifications for scales of the National Conference on Weights and Measures. This specification was first known as master specification 473 . With the development of the Federal Standard Stock Catalog, Federal specifications were classified and indexed, and the general specification for scales was then identified as AAA-S-121.

Several years ago the committee was requested to include in its general specification for scales, requirements relative to automaticindicating scales. The work of revision was undertaken and as this work progressed it was decided to amplify the scope of the specification to make it a more orless complete purchase specifica tion for all ordinary types of weighing scales purchased by the Federal Government. The work of revision was completed late in 1934 and the specification recommended to the Federal Specifications Board for promulgation. It is expected that copies of the printed specification will very shortly be available from the United States Government Printing Office.

This specification does not cover prescription scales, cream-test scales, and railway track scales. This specification differs from the specifications of the National Conference in form and, to a considerable extent, in text. At the beginning of the specification is a section containing some 18 definitions; this arrangement makes it unnecessary to introduce definitions into the body of a paragraph setting forth technical requirements. The definitions are followed by a section of "general requirements", in which are grouped those paragraphs which are applicable to weighing scales in general. The section of "detail requirements" is next in order, and this is subdivided into requirements for beam scales, requirements for automatic-indicating scales, 
requirements for weights, and performance requirements including tolerances and maximum allowable SR values. Four additional sections complete the specification, the first on "method of inspection and test", the second on "packaging, packing, and marking", the third listing "requirements applicable to individual departments", and the fourth comprising "notes."

As compared with the National Conference codes, the text of specification AAA-S-121 has of ten been condensed, and all tolerance tables are condensed; being a purchase specification the tolerances and SR values given are, of course, those for new equipment. While the majority of the technical requirements are those of the Conference specifications, some have been chosen from specifications of the American Railway Engineering Association, and some represent new material developed by the committee; credit is given in the specification to the National Conference as the source of much of the technical matter of the specification. The specification has been criticized for the alleged inadequacy of its engineering requirements, as compared, for example, to the specification of the AREA for motor-truck scales. It is believed, however, that specification AAA-S-121 will serve its particular purpose very well.

The National Bureau of Standards makes available to the Committee on Commercial Weighing and Measuring Devices, information in its files and, when necessary, conducts studies for the information of the committee,just as is done in the case of the Committee on Specifications and Tolerances of this Conference. Many of you will recall investigations formerly made by the Bureau and reported to the Conference, on fabric-measuring devices, liquid-measuring devices, greasemeasuring devices, and taximeters.

Another such study was recently made, the results being utilized by both of the committees I have mentioned. This investigation was undertaken in connection with a question which first arose in relation to the requirements of the Federal specification and the National Conference codes for certain minimum clear intervals between graduations indicating weight or money values. In its final phases this study involved some novel features which it is thought will be interesting to you.

Specifically the issue revolved about the requirement for a clear interval of 0.02 inch between value graduations on a computing-scale chart. This requirement has been in effect for many years in the Conference specifications, and its provisions had been universally applied to the actual clear interval between graduations on the chart itself. The thought was recently advanced by a manufacturer of computing scales that this requirement applied equally to a chart viewed without the aid of any magnifying element and to one necessarily viewed through a lens which magnified the image. It was urged that if what was seen by the unaided eye was satisfactory, a corresponding image seen through a lens should also be satisfactory.

This seemed to be a logical contention. As a matter of fact, I am informed that the Committee on Specifications and Tolerances of the National Conference gave attention to magnifying devices at the time the original specifications were adopted. However, at that time20 years or more ago-the magnifiers in use were somewhat crude affairs; they often distorted the graduations, and thus it seemed that they were not very helpful and that it was not advisable to allow more 
closely spaced graduations when these magnifiers were employed. The situation has now greatly altered, and the magnifiers in general use are superior to those formerly employed. Consequently, it seemed that the matter should be reviewed.

Assuming that a suitable change were to be made in the specification to recognize the principle mentioned above, the question arose as to a method which might be used to determine in a given instance that the magnified image of a chart having graduations less than 0.02 inch apart did, in fact, correspond to an unmagnified image of a chart having graduations 0.02 inch or more apart. The difficulty was that a magnified image is somewhere in space and cannot be directly measured.

Beginning with the actual clear interval on the chart itself, which can be directly measured, it might seem reasonable to suppose that the linear magnification of a given lens system could be determined, and that, by finding the product of the actual clear interval and this multiplying power of the lens, we would directly arrive at the desired value representing the apparent clear interval when viewed through the lens.

This would, in fact, be the case if the magnified image of the chart were at the same distance from the observer's eye as is the chart itself. Actually, however, a lens of the type used on computing scales not only produces a magnified image of the chart but also displaces this image backward from the observer's eye. In consequence, a portion of the effectiveness of the magnification is lost because the magnified image is viewed from a greater distance than is the chart without a lens in place. Both of these effects of the lens-that is, the magnification and the displacement of the image-are taken into account if we employ angular magnification rather than linear magnification.

In other words, the apparent size of an object is dependent upon its distance from the observer's eye. The greater the distance from the object to the eye, the smaller is the angle subtended at the eye by the object, and the smaller is the apparent size of the object [demonstrates on blackboard]. Linear magnification is calculated from the focal length of the lens and the distance between object and lens; angular magnification, in addition, gives weight to the factor of the distance between the image and the eye of the observer. It follows, therefore, that, in considering the magnification of a lens in our scale problem, it was angular rather than linear magnification which we were required to deal with. That, in turn, necessitated, before angular magnification could be calculated, the adoption of some value as the distance of the eye of the observer from the lens, and some assumption as to the position of the observer's eye when the lens was not in place. We adopted 12 inches for the distance in question, and it was assumed that the observer's eye would remain in the same position whether or not a lens were used.

The theoretical value derived as outlined above was checked by direct measurements of the subtended angles of a given chart interval with and without a lens in place. The measurements were made by means of a theodolite mounted with its trunnions in the position assumed to be occupied by the observer's eye. The results of this straightiorward method of determining angular magnification agreed very well with the theoretical value. 
A further check was attempted by photographic methods, because it was felt that if there could be procured physical embodiments of what appears to the eye when observing magnified and unmagnified charts, some aspects of the problem would be simplified, for in this event these could be directly compared and measured. Accordingly a camera was prepared with the ordinary camera lens replaced by a "pinhole"; such a camera gives universal focus effects, and, when the bellows extension is kept constant, may, for comparisons of large dimensions, be assumed to represent the conditions of natural vision. Photographs of the magnified image made with the pinhole of the camera 12 inches from the scale lens, and of the unmagnified image made with positions of camera and scale unchanged were compared, measurements being made on the glass negatives and angular magnification under the stated conditions being computed therefrom. The result was in good agreement with the results obtained by the two other methods.

Having reached this point, it seemed that the investigation was satisfactorily concluded, three methods productive of mutually concordant results having been demonstrated. Very shortly, however, the interested manufacturer represented to us that the basis of all of our computations, theodolite measurements, and photographs was not in conformance with the conditions which would prevail in the commercial use of the scale, in that it had been assumed that the position of the observer with respect to the chart of the scale would remain unchanged whether or not a lens were interposed between the chart and the observer's eye. It was the manufacturer's contention that when an observer viewed the chart through a lens he would be closer to the scale than he would be with no lens present, and that his approach to the scale would equal the distance by which the magnified image was displaced backward from the chart-in this instance, some $23 / 4$ inches.

While the Bureau did not question that the manufacturer was sincere in his belief, it doubted very much that his belief would be realized. Since there were no experimental data available, however, it was a case of "one man's guess being as good as another's." Moreover, you will readily see that the question was fundamental to our problem, since the nearer the observer approached the chart the larger would be the image on his retina; in other words, his approach would, in effect, be equivalent to enlarging the distance between the graduations or to employing a stronger lens. Therefore it was apparent that experimental data on the point should be secured, and accordingly our investigation was resumed for the purpose of learning by experimental methods just what would take place under the conditions involved. In planning this study the aim was to eliminate, insofar as practicable, all variables except the presence or absence of the lens. This is how we went about it.

We decided to make this study as practical as possible, recording by means of large numbers of photographs the actual positions of a representative group of at least 100 observers.

We secured from the manufacturer a special chart with two series of graduations, the widths of the lines and clear spaces being such that the appearance of the more widely spaced series when viewed with the unaided eye was substantially the same as the appearance of the more closely spaced series when viewed through the lens being stud- 
ied. This chart was mounted in a regular scale, with a lens before the closely spaced gradurtions only, and the scale was mounted in a fixed position at a height approximating a commercial installation.

A combination of apparatus was then assembled to permit of the photographic reconding of the positions of the group of observers reading the indications of the two series of graduations. The set-up is indicated diagrammatically in figure 1. As close as practicable to one side of the scale a ground-glass screen, 20 inches square, was clamped in position; this screen was ruled into 1-inch squares by means of steel wires attached to the frame. The center horizontal wire was at the same height as the indicator of the scale. The vertical wires were numbered to indicate their perpendicular distance from the front surface of the scale lens, the central vertical wire being 12 inches from the lens. There was provided a means for indicating in one

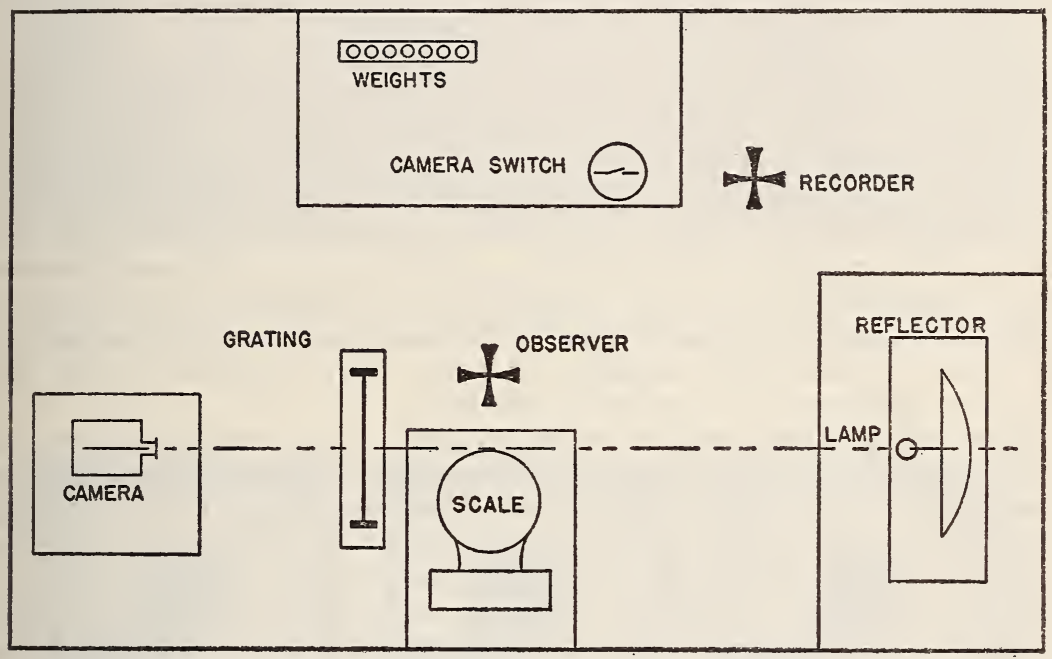

FIGURE 1.-Arrangement of apparatus for investigation of position of observer with respect to scale.

corner of the screen the designating number of each observer and the letter " $L$ " or " $R$ " to show which series of graduations was being read.

Close to the other side of the scale was mounted a 24-inch reflector in combination with a concentrated-filament lamp, and adjustment was made to produce a beam of parallel light directed against the screen. The central axis of the beam passed through the center of the screen at $90^{\circ}$.

On the opposite side of the screen was mounted a camera of special design, electrically operated, adapted to utilize standard motionpicture film and to make individual exposures.

A group of small weights of uniform value was provided for the use of the observers. The recorder was so positioned that he had an unobstructed view of the observer at all times, and the switch for controlling the camera was conveniently at hand.

Disregarding the preliminary work, during which many observations were made, final results were secured from 104 observers. As 
to the characteristics of this group, I may say that 76 percent were men, 24 percent were untrained observers, 36 percent wore glasses, the average age was 37 years, and the age range was 19 to 66 years. All instructions to observers were in writing, to place each observer on the same basis as all others. Each observer was given full instructions for reading the scale indications and full opportunity to familiarize himself or herself with the scale. Instructions for the "record" observations stressed the accuracy of the reading but, of course, made absolutely no reference to the distance of the observer from the scale; further to focus the attention of the observer on the idea of accurate reading, all values announced by the observer were carefully recorded by the recorder, although the only purpose of this was the psychological effect.

The method of operation was for each observer to make 12 consecutive readings from one series of graduations, weights being applied by him to the scale platter one at a time. A similar series of observations was then made from the other series of graduations. The first two observations of each series were not officially recorded. For each of the others, the recorder closed the camera switch as nearly as possible at the exact instant when the observer was actually making his reading, photographing the shadow of the observer's profile on the ground glass screen and thus definitely recording the observer's distance from the scale lens. [See fig. 2.] The real purpose of the observations was not revealed to the observers, and none of them knew that we were interested in their position with respect to the scale; in fact, the majority of them were ignorant of the fact that any photographs were being made.

When all of the negatives were secured, the photographic results were reduced to numerical data by projecting each negative on a screen, the positions of the various observers being then read and checked by two persons. The distance of the observer from the scale was read to the notch in the silhouette nearest to the observer's eye. [See figs. 3, 4, and 5.] Results were then averaged for each group for each observer, the difference was determined between the mean values for the two series for each observer, and the resulting data were analyzed. In all computations of "differences" the position of the observer when viewing the unmagnified chart was considered the standard, and the position when viewing the magnified chart was compared with this. Thus if the observer was closer to the scale when viewing the magnified chart than he was when viewing the unmagnified chart, his difference was considered to have a minus sign; when conditions were reversed, the difference was called plus.

In figure 6 is shown a distribution chart of the "differences" for the 104 observers. For all observers the mean difference was -0.7 inch, which is to say that the average observer of our representative group approached the scale 0.7 inch when viewing the magnified image as compared with his position when viewing the unmagnified image. Differences for individual observers ranged from -3.4 to +3.1 inches. Seventy-five percent of the observers had minus differences; 21 percent had plus differences; 4 percent had zero differences - that is, their mean positions for the two series of observations were the same. It is interesting to note that the mean difference for observers wearing glasses was approximately twice that for ob- 


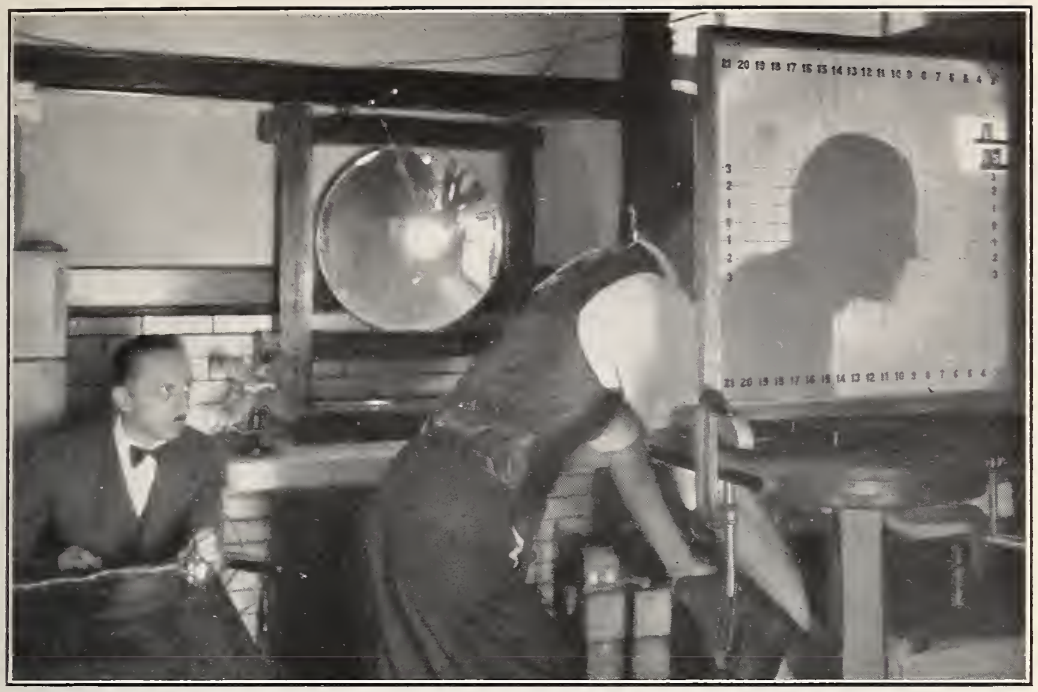

FIGURE 2.-Wethod of recording positions of observers with respect to scale.

The shadow of the observer on the ground-glass screen was photographed. The position of the shadow with respect to the lines on the screen defined the position of the observer with respect to the scale.

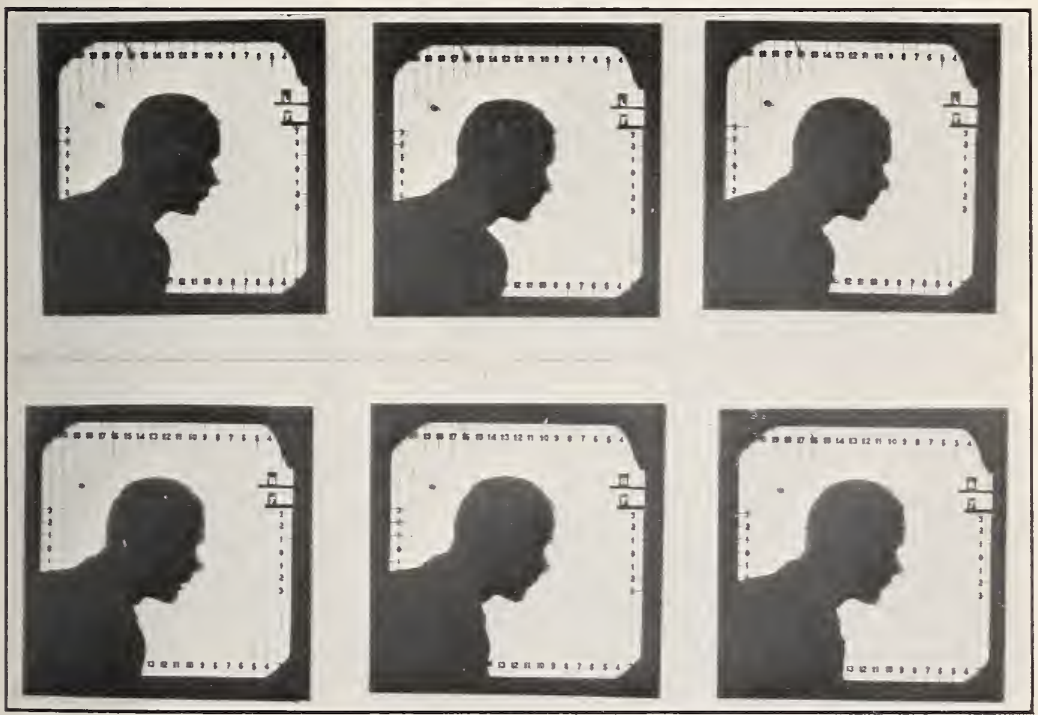

FIGURE 3.- Photographs of an observer having average vision.

In the three upper views the obserrer was riewing the chart direct; in the three lower riews he was riewing the chart through the scale lens. The average distance of this observer's eyes from the scale was the same both with and without the lens in place. 


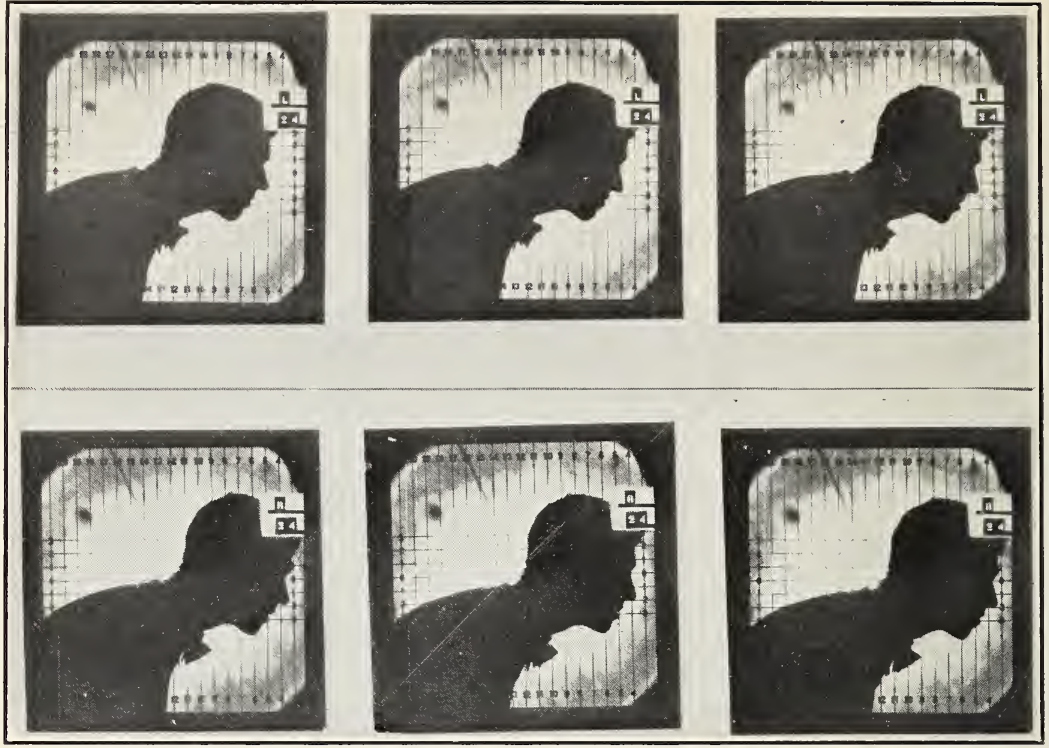

FIGURE 4.-Photographs of a near-sighted observer.

In the three upper views the observer was viewing the chart direct; in the three lower views he was viewing the chart through the scale lens. The average position of this observer was 1.8 inches closer to the scale (a relatively large amount) when viewing the chart through the scale lens than when viewing the chart direct.

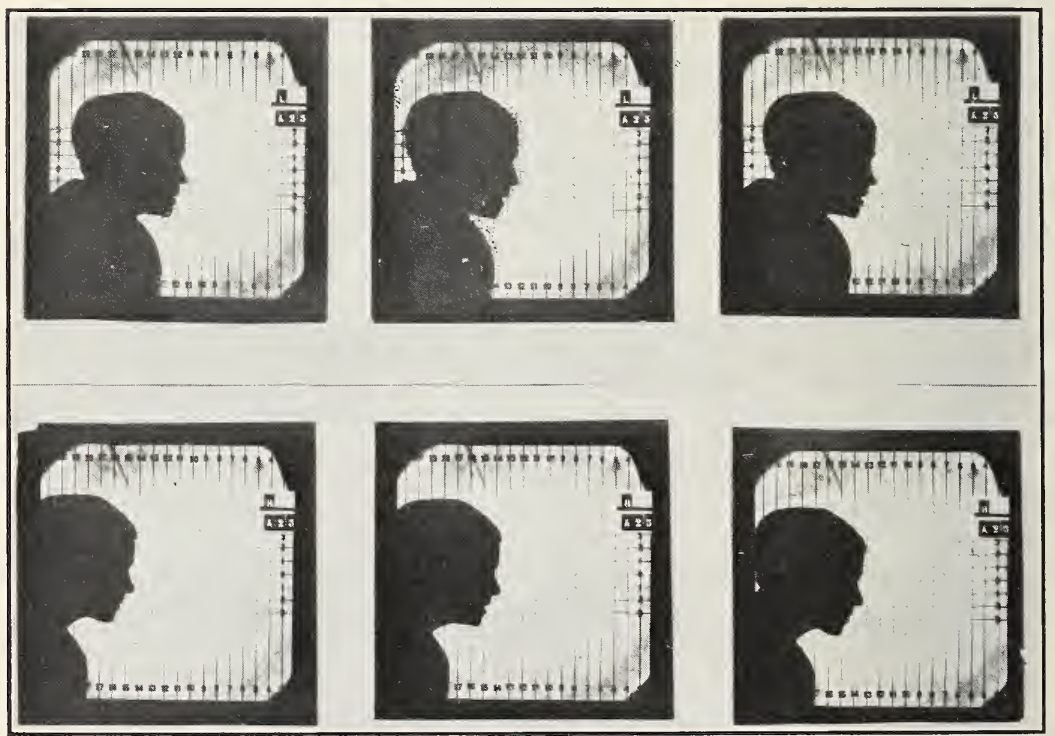

FIGURE 5.-Photographs of a far-sighted observer.

In the three upper views the observer was viewing the chart direct; in the three lower views she was viewing the chart through the scale lens. The average position of this observer was 2.3 inches farther away from the scale (a relatively large amount) when viewing the chart through the scale lens than when viewing the chart direct. 


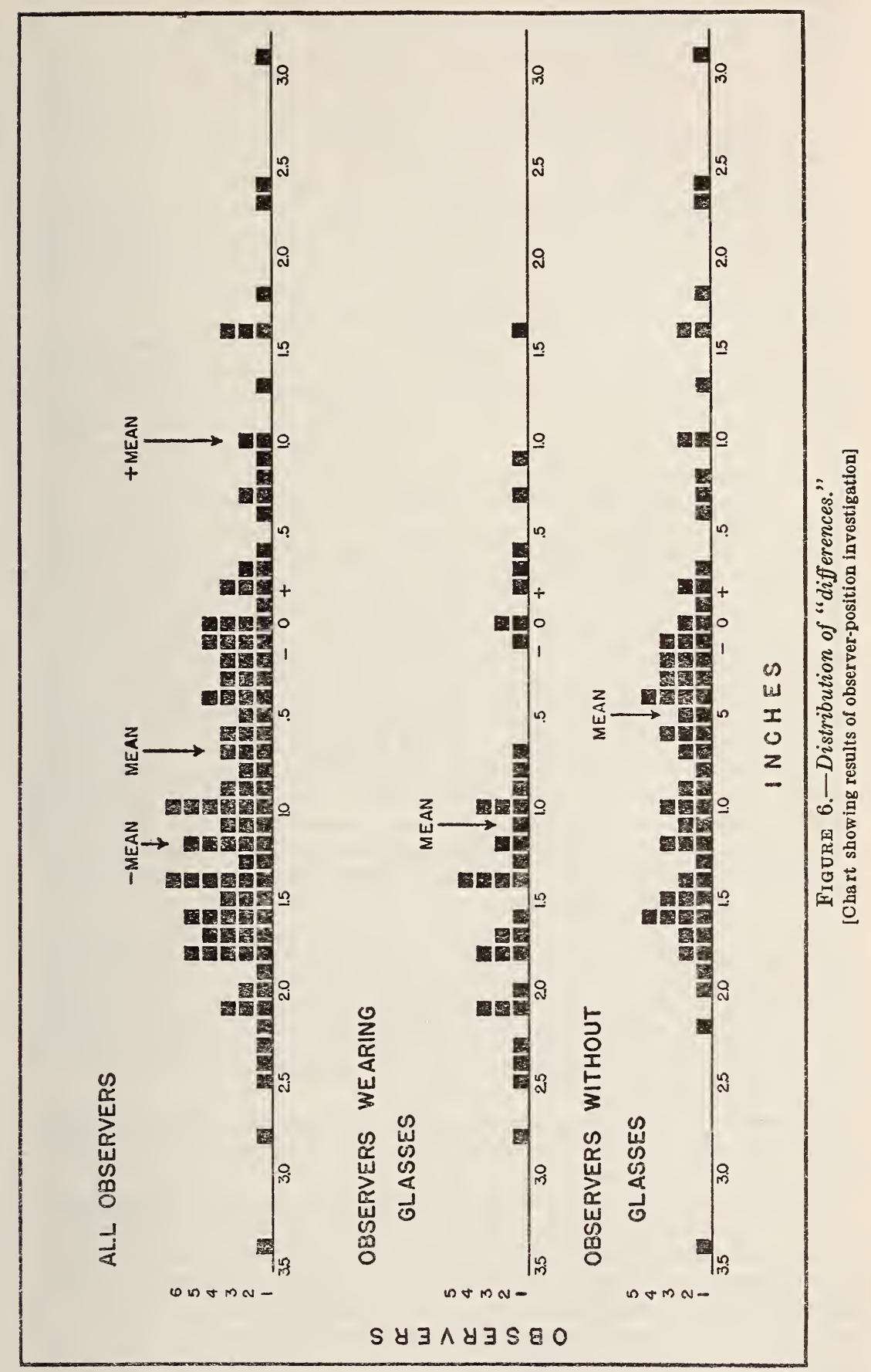


servers without glasses (-- 1.1 and -0.5 inches). Mean differences were the same for trained and untrained observers, and for men and women. When the differences were plotted according to the ages of the observers, there was indicated a trend toward increased minus differences with increasing age. When the results were distributed on the basis of the nearsightedness or farsightedness of the observers, no significant information was disclosed.

Another interesting fact developed was that for readings of the magnified chart the average position of the observer's eyes was 9.05 inches from the outer surface of the lens; this was increased to 9.75 inches for readings of the unmagnified chart. For all observers these positions ranged from 2.8 to 15.9 inches for the magnified chart and from 4.3 to 16.9 inches for the unmagnified chart.

From all of these results it appeared that there was something in the contention that the average observer would position his eye somewhat nearer to the chart when a magnifier was employed than he would when no lens was in place, and would thus, in effect, slightly enlarge the magnified image. The results indicated that the estimate that the observer would position his eye $2 \frac{3 / 4}{4}$ inches closer to the chart when utilizing the lens, was not borne out in practice, the actual advance being only about one-fourth of this figure. The experimental result enabled the Bureau to decide what magnification was necessary to produce an image equivalent to the image of an unmagnified chart. The work was undoubtedly worthwhile, because it not only solved the case at hand but gave us a better insight into the fundamental requirements and laid the groundwork for the formulation of a general specification on the subject of magnifiers. The committee decided to recognize the principle that if a certain combination of graduation lines, clear interval between graduation lines, and indicator is to be permitted on an unmagnified system, there should likewise be permitted any combination which, when necessarily viewed through a magnifying system, presents to the eye of the observer an apparent combination not less readily readable than the unmagnified combination. This is expressed in specification AAA-S121 in the following language:

Magnified Indicating Elements.-When in normal usage any indicating elements are necessarily viewed as magnified by means of a lens system, the requirements of paragraph $\mathrm{D}-7 \mathrm{a}$ as to minimum width of graduation and of paragraph $\mathrm{D}-7 \mathrm{~b}$ [relative to the clear interval between graduations] shall be that the apparent size of the magnified image of such elements as seen by an observer occupying a normal average position with respect to the scale shall be equivalent to the apparent size of elements complying with the stated requirements and viewed by the unaided eye from a normal distance.

It is my understanding that a similar paragraph is to be presented somewhat later for your consideration by your committee on specifications and tolerances.

It seems to me to be an excellent plan to make such investigations as the one I have outlined, for the purpose of the development of proper general specifications. When these requirements are founded on demonstrated facts, they are less open to legitimate objection and they should inspire a feeling of confidence on the part of all concerned-the manufacturer who produces in accordance with them, the official who enforces them, and the consumer who buys over apparatus regulated by them. 
I think it probable that we shall hear much concerning magnification in the near future, and so it is well to have outlined the basis underlying the use of magnifiers. A guide to manufacturers planning new designs will certainly facilitate the development work necessary, and will do much to forestall expensive failure.

In conclusion I wish to say that the National Bureau of Standards does not have available for distribution copies of Federal Specification AAA-S-121. The regulations governing the distribution of Federal specifications provide that those desiring copies must secure them through purchase from the Superintendent of Documents, United States Government Printing Office, Washington, D. C. We understand that the price of this specification will be 5 cents per copy.

The Chairman. Thank you, Mr. Smith. I am sure that the delegates appreciate the time and effort that you have spent in the preparation of your paper, and it demonstrates clearly the distinct contributions that the Bureau offers to the States and to the manufacturers on questions of this nature.

\section{DISCUSSION OF REPORT ON SPECIFICATIONS, TOLERANCES, AND} REGULATIONS FOR PERSON WEIGHERS-Continued

The Chairman. Now, gentlemen, we will resume our program where we suspended yesterday. We were discussing the committee report on the person-weigher code, paragraph 2.

Mr. O'Keefe. Mr. Chairman, Mr. Holbrook and his committee have given these items a great deal of thought, and I think that their considerations have been not for some local community, but for the United States at large. I think their conclusions in the matter should be adopted by this Conference. So, I move you, Mr. Chairman, that the recommendation as submitted by this committee be adopted as a whole.

(The motion was seconded.)

Mr. HoLвRоoк. In order that the Conference may not take action without all facts in mind, I may say there was a proposal made and debated yesterday that specification 9 be made nonretroactive. Your committee took no stand on that. Except to call it to your attention, I have nothing to add to what I said yesterday, in that relation.

Mr. BaUcom. Mr. Chairman, I feel that some of these men probably have not a clear-cut conception in their mind as to the difference between the specifications and the regulations. As I understand it, a specification is just a guide to the manufacturer in the construction of his scale. A regulation, as I conceive it, is what we have to enforce to make sure that apparatus in use complies with the specifications.

Now if we make this specification 9 retroactive, scales already made, and in use, will have to be rebuilt. I think a regulation can be drawn in any section to cover this. But if you draw a specification and make it mandatory on scales in use, you will find that these scales do not comply. I do not feel that this should be retroactive.

There is one other point I would like to bring to your attention. That is the requirement that the maximum allowable sensibility reciprocal shall be the value of two of the minimum graduations on the beam for scales in use. I don't think there is a scale manufacturer here who would admit he could not comply with a sensibility recipro- 
cal of one of the minimum graduations on the beam; that is, 1 pound. I would like to make an amendment to require that the maximum allowable sensibility reciprocal on scales in use be the value of one of the minimum graduations on the beam.

Mr. Holbrook. Mr. Baucom, the sensibility reciprocal requirement in this specification is identical with the requirement embodied in the code for commercial platform scales. If the values were to be cut to the value of one of the minimum graduations and one-half of one of the minimum graduations, for scales in use and for new scales, respectively, we would be in a position of demanding that person weighers be twice as sensitive as commercial scales in use in the country at the present time. Moreover, this would be a particularly difficult thing to enforce, because, whereas in the case of the commercial scale the manufacturer may select his own minimum graduation, in the case of person weighers the value of the minimum graduation is rigidly specified, 1 pound. I hardly think that the Conference would want to take the attitude that a person weigher should be subject to more stringent regulations than commercial scales.

Mr. Waldman. Will Mr. O'Keefe agree to an amendment that specification 9 be nonretroactive? I think that is of value and I make that amendment.

Mr. O'KeEFE. I will accept the amendment so far as I am concerned. However, I would like to hear an expression from the committee. They have given this a lot of thought and I think they ought to be heard.

Mr. Holbrook. The committee has not taken any action since the proposal was made that specification 9 be nonretroactive. The committee was not requested to consider the advisability of making this specification retroactive. I think in this particular instance we would have to poll the committee individually. Personally I would have no objection to seeing the specification made nonretroactive. The other members might express their own thoughts on the matter.

Mr. Schiemer. Mr. Chairman, if this code is passed by the Conference today, is my understanding correct that it would be up to the various States to set some date after which it is to be effective? Is it intended that it date back 3 or 4 years? What would the recommendation of the Conference be?

Mr. Holbrook. This specification upon adoption by this Conference is automatically recommended to the States for adoption. Each State which adopts the code will presumably set a date at which it is to take effect.

Mr. Schiemer. Would that be some date prior to this time, or some date hereafter?

Mr. HolbROoK. At some time in the future. The retroactive specifications of the code would take full effect at that time. The nonretroactive specifications would take effect only on new apparatus being brought into a juxisdiction, or sold in a jurisdiction after the date of promulgation in the jurisdiction. The apparatus in use at the time of the promulgation would not be liable to be condemned on account of failure to comply with specifications which are nonretroactive in their terms. 
Mr. Griffith. Unless the jurisdiction has already adopted and promulgated them.

Mr. НоцвRоок. As I said, that depends upon the jurisdiction adopting it.

Mr. Griffith. Mr. Chairman, what Mr. Schiemer is trving to bring out is the fact that in Baltimore we adopted these specifications in 1932. Certainly after that date the manufacturers were put on warning that the specification would be enforced. Mr. Schiemer wants to know whether the passage of paragraph 2 of this code, which is now being made nonretroactive, affects the former adoption of the code in jurisdictions such as Massachusetts, Ohio, and Baltimore, which already have put this paragraph into effect.

Mr. Schiemer. I just wanted to get the opinion of the Conference itself. Mr. Holbrook, in view of the fact that some changes are being made in the tentative code adopted by the Conference, I wonder if the Conference would consent to let it lie on the table for a yearuntil the next Conference. We could then have a final hearing before it is effective in any jurisdiction where it has worked a hardship on some of us.

Mr. Holbrook. So far as the National Conference on Weights and Measures is concerned, this code is tentative until finally adopted. We have been over the ground very thoroughly in this Conference. It must be granted without question that any jurisdiction, which has power to make rules and regulations on apparatus, may make rules and regulations without reference to any action of this Conference. Such a jurisdiction may take the code as proposed by this Conference, or it may write an entirely independent code without reference to this Conference, or it may amend the Conference code as it sees fit to do so. Neither the Conference nor the National Bureau of Standards will attempt to interfere with any such action, nor will these organizations attempt to take any action whatever in cases where a code has already been adopted.

The Charrman. Gentlemen, are you ready for action on the question? The question is on Mr. O'Keefe's motion that the code of specifications, tolerances, and regulations for person weighers be adopted as recommended by the committee on specifications and tolerances.

(The question was taken, and the motion was agreed to.)

Mr. Houbrook. For the sake of the record, may I ask whether Mr. O'Keefe accepted the amendment to make specification 9 nonretroactive?

Mr. O'Kenfe. Mr. Chairman, I said I would accept that amendment, but I asked for the opinion of the committee. The committee was not polled about the requested amendment; however, it was all right with me.

The Chairman. The motion to amend was not seconded; therefore, the amendment was not properly up for consideration.

Mr. Rogers. Mr. Chairman, so far as the committee is concerned, the suggestion made here was never heard before the committee. I think either decision would be satisfactory to the committee. 


\section{SUPERVISION OVER THE BUYING OF OLD GOLD} By Elliotr B. Holton, Assistant Superintendent of Weights and Measures,
State of New Jersey

Late in 1933 the price of gold began to climb as the Federal Government entered the market to buy up the precious yellow metal. Daily the price per troy ounce rose, until the value was fixed at $\$ 35$ an ounce through the action of the President, who revalued the United States gold dollar by proclamation of January 31, 1934, under the act of May 12, 1933, as amended by the Gold Reserve Act of January 20, 1934. This was an increase of about 69 percent over the rate that had prevailed for years.

During this period of skyrocketing prices, gold was brought to the attention of the great American public. It was made gold-conscious by advertisement, by newspaper comment, by radio, and by personal door-to-door canvassing. Citizens were made aware of the fact that there was ready money waiting for the accumulations of worn-out, broken, and discarded jewelry lying about the houses of the Nation. And with this first wave of excitement that swept the country came a horde of nimble-witted gentlemen who were eager to aid the householder to convert his old gold into cash, with, of course, mental reservations as to the amount of profit these same clever men could make for themselves.

Many of the pioneer gold buyers knew no more than that gold was a yellow metal and that it was valuable, but at that they were two steps ahead of the average citizen.

So long as gold buying had been confined to trading with legitimate dealers, in long-established stores and factories, there was small cause for doubt as to the honesty and integrity of those engaged in this business. With the advent of the house-to-house canvasser, it was vastly different. These itinerants were "birds of passage", who had no fixed location and who roamed the earth like a band of gypsies. As theirs was a "hit-and-run" trade, they never tarried long in a neighborhood. It became a merry old game of hide and seek to track down these wandering merchants and check on their methods of doing business.

Not long after the "fly-by-night" type of gold buyer made his appearance on the scene, stories came to the ears of weights and measures men that scales were false; that weights were as bad; and that all of the time tested and proved knavery and crooked weighing were in use. Some of these tales turned out to be wild rumors; others were true in all the sordid details.

The local departments of the State of New Jersey scouted around in cars attempting to catch up with the clever boys who were making a racket of gold buying. The State department prepared articles warning the public to beware of the men who came to the house to buy gold and suggested that it would be better to deal with established firms. These articles appeared in the leading daily newspapers of the State, which were willing and powerful allies in the educational campaign.

At the January 1934 midwinter conference of the weights and measures association, superintendents, who had felt the first effects of the gold buyer and his shady dealings with the public, acquainted the members present with the sharp practices that had come to light in their territory. 
One of the first clever dodges that was run to earth and broken up was that of using scales that were held in the hand of the gold buyers. Adept handlers of this type of scale could throw the balance by a muscular twist and always in their own favor. A ruling promulgated by the State department made the use of this scale illegal. Only scales that were mounted on a rod or stand and were beyond the reach of clever hands to deflect pans were permitted. All others were to be confiscated and the owners prosecuted.

Another deceitful buyer used a 1-cent coin as a pennyweight unit, thereby gaining double value on his purchases of old gold. Too numerous for repetition are the tales of would-be sellers who refused the first appraisal of their goods, then went to a reliable dealer who gave them 4 and 5 times as much as the first offer.

The men in the field and the Trenton office kept a vigilant eye on gold buyers. The monthly bulletins of May and August 1934 both called attention to the fact that gold buyers were still abroad in the State. From May 5 to June 30, 1934, an intensive drive was made. One of the State assistants accompanied the local city and county men to all persons and firms dealing in gold. He reported as follows:

\begin{tabular}{|c|c|c|c|c|}
\hline Test of- & Correct & Adjusted & Condemned & Total \\
\hline $\begin{array}{l}\text { Equal-arm balances. } \\
\text { Troy weights- } \\
\text { Karat weights- }\end{array}$ & $\begin{array}{r}125 \\
1,079 \\
758\end{array}$ & $\begin{array}{r}4 \\
376 \\
25\end{array}$ & $\begin{array}{r}7 \\
133 \\
37\end{array}$ & $\begin{array}{r}136 \\
1,588 \\
820\end{array}$ \\
\hline
\end{tabular}

In Jersey City, second largest city in the State, no person, firm, or corporation may engage in the business of buying old gold without having first obtained a permit from the chief of police. Since the police and the weights and measures departments are in close harmony no gold buyer starts without having a permit or a test of his scales and weights.

A total of 74 permits were issued in Jersey City and during April the local tests were as follows:

\begin{tabular}{|c|c|c|c|c|}
\hline Test of- & Correct & Adjusted & Condemned & Total \\
\hline 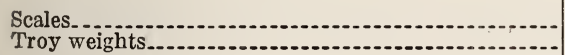 & $\begin{array}{r}44 \\
849\end{array}$ & $\begin{array}{r}2 \\
156\end{array}$ & $\begin{array}{r}33 \\
272\end{array}$ & $\begin{array}{r}77 \\
1,142\end{array}$ \\
\hline
\end{tabular}

Probably the worst set of equipment was picked up in Jersey City. This consisted of four irregular lumps of a metal, presumably lead, and a bronze souvenir medal. Without rhyme or reason the lightest weighed 5 pennyweights, $22^{1} \frac{1}{20}$ grains, and the heaviest 1 ounce, 5 pennyweights, $103 \%$ grains.

Much has been inferred as to the dishonesty of the gold buyer in the first part of this paper, but it must be stated here and now, that not all the men who engaged in this work tried to make a racket of it. There are many phases of gold buying that may confuse the layman and that tend to put the dealer in a far more unfavorable light than that in which he should be placed. For instance, while the Government rate is $\$ 35$ an ounce, few pieces of $24 \mathrm{~K}$ gold are to be found. Since alloy is worthless, a quantity of $14 \mathrm{~K}$ gold is valued 
only at $14 / 24$ of $\$ 35$, or $\$ 20.41$. Gold of lesser karat weight is worth proportionately less by the gross ounce.

Most important to bear in mind is that while the Government pays $\$ 35$ an ounce, the gold buyer is not in business for his health nor is he working for the convenience of householders who deal with him. The gold buyer is entitled to a profit for his time and work, but it should be a fair profit and not an illegitimate one.

If time will permit, it might be well to acquaint you all with the far from easy matter of selling gold direct to the Government. Two assay offices are located in downtown New York and they are open from 10 a.m. to 2 p.m. A locked gate confronts the citizen as he approaches, which is opened by a guard and closed behind him. There are two windows at which gold is tested and weighed and a citizen must have an affidavit with him that he acquired and transported the gold legally. All gold-filled articles of less than 200 in 1,000 parts are promptly turned back by the clerks. Tests by file and acid come next, after which the heap is weighed and a receipt given the depositor, while a duplicate accompanies the gold through the assay office.

Each lot of gold is melted down separately and is poured in a rough ingot $1 / 2$ inch thick by 3 by 6 inches. The after and before melting weights must agree. Two samples are nipped from the cold bar and these are the size of a .45-caliber bullet. Three skilled assayers run the tests, and when the gold content has been determined the depositor is notified to come for his check. A deduction is made for the handling charge. Possibly a week may elapse before the citizen who brought the old gold to the assay office receives his money for it.

After you have heard this tale of red tape and waiting you may understand why a citizen with an ounce or fraction of an ounce of old gold is willing to turn to the gold buyer to take on this trouble.

Gold buying was one of those sudden emergencies that so often confront weights and measures departments throughout the nation. The usual vigilance of an alert corps of men reduces the period during which the uncontrolled and fraudulent practices may rage and the matter is soon well in hand and regulated for the protection of the general public and the honest merchant.

The Chairman. Thank you, Mr. Holton.

A STUDY OF THE PROMULGATION OF RULES AND REGULATIONS AS APPLIED TO THE VARIOUS STATES OF THE UNION

By C. D. Baucom, Superintendent of Weights and Measures, State of North Carolina

Mr. President, members, and guests: When Mr. Holbrook requested that I prepare a paper on weights and measures regulations, exclusive of specifications and tolerances, as promulgated by the various States of the Union, I hesitated, and it was with reluctance that I accepted, knowing that to do the subject justice, research work would require more time than intervened from then until convening of the Conference. However, I immediately sent out questionnaires to all of the States and the District of Columbia asking that copies of laws, rules, or regulations under which they operated, and any comments they might have as to contemplated regulations, be sent as promptly as possible together with return of questionnaire. Of these 49 questionnaires sent out, 35 were returned and right here I wish to 
express my appreciation of the cooperation and comments, in compliance with my request.

The rules and regulations promulgated by the various States are, in general, synonymous with those adopted by this National Conference and recommended by the National Bureau of Standards. I notice that some States have adopted such rules and regulations by act of legislation. Out of the 35 States reporting, 22 of them have adopted Handbook M85 as a general guide in carrying out the mandates of the law. Two or more States make rules and regulations acts of legislature. Fourteen States place in the enforcing office the power to make rules and regulations. The regulations in 11 States are promulgated and/or approved by a board of authority. Eight States reporting have no State enforcing agency at all. However, as a carryover of old laws, these States give power to county, municipal, or local authorities to appoint local officers for enforcing weights and measures. Thus you will see from the foregoing that to give a résumé of the rules and regulations promulgated under the various set-ups and conditions would extend far beyond the time allowed for this subject and intrude upon your patience as well.

In studying this subject as carefully as time would permit and by a process of separation, analyzation, and coordination, deductions reveal that rules and regulations promulgated by the various weights and measures set-ups fall into five classes or systems as follows: First, by act of legislature; second, by commissioners, superintendents, or enforcing officers; third, by council or board of authority; fourth, by adoption of those perfected by the National Conference on Weights and Measures; and fifth, by combination of two or more of these ways. I shall not dwell at any length on the advantages and disadvantages of these methods but do call your attention to some of the so-called "high spots."

Under circumstances mentioned in class 1 , if a condition should arise as a result of progress or otherwise which needs to be regulated, the weights and measures official must wait until the legislature meets, and prove to the representatives the necessity of such a regulation (a rather difficult task) before he is able to cope with the situation-unless fraud is being perpetrated in which event he at all times has power to intervene.

The second class or system has considerable advantage over the first in that the enforcing officer is able to make rules or regulations immediately upon demand; yet the advisability of vesting so much power or authority in one man has been questioned. He is, by act of the legislature, given the power to make and enforce his own laws, being vested with police powers and backed with State authority. No other officer has such power, not even the Governor himself. He has the power to prosecute and even to persecute, though unintentionally and without prejudice, depending upon his knowledge of facts and conditions and his ability to cope with the situation. There is no record of such an official usurping such power to his own aggrandizement or for advancing his own political aspirations or prestige, and I do not believe there is a weights and measures official anywhere in these United States who would take advantage of such authority. Nevertheless, the fact remains that under such a set-up there is the possibility of developing an autocratic system and of bringing about criticism. 
Rules and regulations promulgated under the third method, by a board of authority or council, is more democratic than the second and there is less tendency toward autocracy, in that, as a general rule, before any rule, regulation, or ordinance is put into effect a public hearing is granted, giving all parties concerned an opportunity to express their views, both pro and con, thus assuring fair and just rulings. Yet in a good many instances the board of authority or council is largely influenced by the recommendations of the enforcing officer and acts accordingly. Such action can be explained partly by the fact that the board or council is none too well informed regarding the details of weights and measures activities, nor of circumstances which would warrant new or additional regulations, and therefore naturally relies upon the sincerity, the judgment, and the ability of the enforcing officer for guidance in its actions.

In the fourth class - that of adopting rules and regulations promulgated by the National Conference on Weights and Measures and recommended by the National Bureau of Standards-advantage is taken of the combined interest and experience of those who have studied and are best acquainted with weights and measures problems and how to deal with them. Members of this Conference are men who are whole-heartedly interested in developing and advancing the cause of weights and measures without prejudice, in a manner best suited to the needs of the people concerned, in bringing about just and fair practice in trade, and in endeavoring at all times to put an end to the use of weighing or measuring devices in the perpetration of fraud, deception, or trickery. Upon first thought it would seem that such a system would be best of all, yet let us note the disadvantages. The Conference meets once a year and not always that often. According to procedure practiced thus far by the Conference, the necessity for a new regulation is presented to a committee, who after hearing the facts and studying the circumstances and conditions involved, promulgate a regulation and present it to the Conference for discussion. If adopted, it is adopted tentatively and lies on the table for 1 year subject to further study by all concerned, to be finally adopted at the next succeeding Conference. It is then recommended by the National Bureau of Standards for acceptance and adoption by the various weights and measures departments of these United States, effective on some fixed date, which often is a year later. Thus, you see, the disadvantage here is the same as noted under class 1 already shown.

We now come to consider class 5 , a system of combining two or more of the foregoing set-ups. Upon careful study of the different ways of making rules and regulations it is concluded this system is more nearly ideal than any. It is more adequate, more flexible, and more democratic; that is, if the combination consist of systems 3 and 4 already mentioned, the disadvantage of one is offset by the advantages of the other, and vice versa. It is suggested that every weights and measures man here who operates under a different set-up give this serious thought, and if in agreement, set about to get his law so changed as to adopt the rules, regulations, specifications, and tolerances promulgated by the National Conference on Weights and Measures and recommended by the National Bureau of Standards; provided however, that such additional rules and regulations as are needed to carry out the intent of the law-which is to protect the 
purchasers of any commodity-shall be promulgated by the commissioner, superintendent, or enforcing officer of weights and measures and adopted by the board of authority. This is the system in force in my State, North Carolina, and it is very satisfactory. In short we adopt the rules and regulations promulgated here if we like them and they meet the requirements and needs of our people according to the intent of the law, and if we don't like them, or they are inadequate, we make our own rules and regulations. Thus we have a very flexible system, able to keep abreast with the progress of the age and to cope with any situation that may arise.

Proof of a theory is its application and consequences. I therefore cite you to results obtained under such a system by the State of North Carolina, though there are other States with similar experiences. In 1931 the North Carolina General Assembly adopted system five, as just explained. Very soon thereafter a question arose relative to the sale and distribution of weighing and measuring devices. Practically every department of weights and measures in the land requires the enforcing officer to "keep a general supervision of the weights and measures and weighing and measuring devices offered for sale, sold or in use" in the territory he supervises. We found no record of a regulation having been adopted or recommended by the National Conference. Therefore, under the mandates of the law our board promulgated what is known as "regulation no. 7", which requires all weighing and measuring devices offered for sale, sold, or distributed in North Carolina to be first submitted for test and approval. The heart and soul of our law is to protect the person who is unable to protect himself, in relation to weights and measures. Thus this regulation was to prevent the sale and distribution of such devices as would aid in the perpetration of fraud or deception in their operation or use and thus would ultimately be caught and condemned while in the possession of an innocent offender of the law. This regulation was put into effect in August 1931, and I might add that between 2,900 and 3,000 weighing and measuring devices have been submitted for test with less than 2,000 approved. Next came the ice problem known as "scored" ice. We recognized the merits of this and made regulations accordingly. Every one here has had more or less trouble with coal deliveries and North Carolina was no exception. The socalled "club car" purchase was becoming a "racket"; in fact it was a nuisance. This practice was carried on under the guise of collective bargaining and defended by claiming it was within the private rights of individual citizens, but we found that the private citizen was being preyed upon. The agent or solicitor for carload purchases was not only taking no part of the coal so purchased, but was delivering by estimated weight around 5 to 10 tons in excess of bill-of-lading weight resulting in a profit to said agent or solicitor handling a 50-ton car (they usually ordered small cars) of his regular commission on 50 tons, the short weight and sale of an additional 10 tons, and delivery charge on 60 tons. So regulation no. 9 was promulgated, which takes care of the situation so far as law is concerned.

In turn, questions and conditions arose requiring a ruling or regulation on the visibility of scales; net weight; what constitutes a package; when is a gallon of gasoline a gallon; bulk hauling of petroleum products; vehicle or truck tanks, and bulk plant meters. I mention these to show the efficiency as well as flexibility of our law, 
rules, and regulations in carrying out the purposes and intent of said law and in taking care of new conditions resulting from progress.

Summing up and observing from a national viewpoint, it would seem most advisable that every weights and measures office, whether large or small, should take such action as may be necessary to enable it to acquire full benefit of the combined knowledge, experience, and advice of the men who constitute the National Conference on Weights and Measures. Such men above all men are best qualified for advising. Free from prejudice or personal gain, they have but one motive, one purpose, and one aim in all their acts, and that is to protect the purchaser. In response the Conference should realize the importance and the seriousness of, and should respect, the trust and power vested in it, and should hedge itself about with such rules and regulations governing its own procedure and actions as to warrant such trust and respect.

In conclusion, with rules and regulations promulgated by the National Conference on Weights and Measures and recommended by the National Bureau of Standards, and with power to add to or reject by State or local authorities-thus upholding the sovereignty of the State and of States' rights and the right of local self-government recognized and sanctioned jointly and severally by State law-the weights and measures department can be and will be a power and a glory in any community where it operates. It will have the respect and good will of all the people and those who carry on the work will be honored and duly rewarded for their efforts.

The Chairman. Thank you, Mr. Baucom.

\section{THE LABELING AND CERTIFICATION PLAN IN CONNECTION WITH FEDERAL SPECIFICATIONS}

\section{By A. S. McAllister, Assistant Director, National Bureau of Siandards}

Mr. Chairman, ladies, and gentlemen, many persons unfamiliar with the official duties of the Bureau and its relations to Congress, have been led to believe that the Bureau is accepting money collected from the public in the form of taxes while failing to give to the public the benefit of information acquired by it at the expense of the taxpayers.

Congress is the official agency elected by the people to look out for their interests, with special reference to the expenditure of the peoples' money for governmental services. An examination of the functions of the National Bureau of Standards as laid down by Congress, the appropriations made by Congress for the activities of the Bureau, and the official records of the Bureau's accomplishments will show that the Bureau is performing its functions in a manner thoroughly satisfactory to Congress.

Numerous groups interested in the problems of the "consumers"meaning "over-the-counter" buyers as distinguished from contract buyers-are inclined to request from the Bureau services which it is neither authorized nor able to render. Congress has not seen fit to empower the Bureau to render the services demanded by these groups. However, within the limitations placed by Congress on the services of the Bureau, this agency carries on many activities of direct and determinable service to the consumers-both contract and over-the-counter buyers. 
The Need for Quality Specifications.-If all buyers could become expert in the identification and purchase of all groups of commodities, and could keep continually posted on changes and improvements introduced in all branches of industry, there would be little need for quality specifications. Only when a person can specialize on the purchasing problems in a single industry, that is, can become qualified to serve, for example, as the purchasing agent for one of the many parts in a general department store, can he be considered sufficiently expert to have little need for standards of quality. Incidentally, let me say that the most expert of such experts are depending more and more upon definite specifications to record conclusions based on their experience and guide their judgment. Moreover, they augment their own personal inspecting facilities by elaborate testing services.

If a lifetime devotion to a single group of commodities is required to educate an expert buyer in a limited field, there can be no doubt that the person who does merely incidental buying cannot possibly become expert in all commodities and he will seldom be rated as an expert in even one line.

Inexpert buyers (and that grouping includes all of us so far as concerns the great majority of commodities) need the aid of standards to guide them in determining what qualities certain commodities should possess and in identifying commodities possessing these desirable qualities.

Contract buyers, those who purchase large quantities of certain commodities on definite written contracts, can set forth their requirements in the form of specifications submitted to competitive bidding and are in position to tell the manufacturers just what they want and to determine by means of tests whether the commodities delivered comply with the specification requirements. To a certain extent over-the-counter buyers benefit from the quality standards established by contract buyers in cooperation with the producers in case the commodities are properly identified as complying with the specification requirements.

In the work of selecting satisfactory specifications and establishing satisfactory means for identifying commodities complying therewith, all organized groups of purchasers, both contract and noncontract, can appropriately take a very active and effective part. From the point of view of noncontract purchasers, that is, over-thecounter buyers, identification of commodities satisfactory for their uses is of outstanding importance. It is in connection with the preparation of specifications and the identification of commodities complying with specification requirements that the National Bureau of Standards can be most helpful to consumers.

Testing at the National Bureau of Standards in Relation to Overthe-Counter Buying. - The United States Government uses specifications in purchasing its supplies. Each specification lists the required properties of the article which is being purchased. In supplying rope, for example, the requirements of the specification as regards the kind of fiber, the diameter, the weight per foot, the oil content and the breaking strength must be met. No brands or trade names are used in the specification and any manufacturer who can supply the article with the required characteristics is free to bid. This eliminates favoritism and promotes free competition. 
The order goes to the lowest bidder, and the goods are tested after delivery to determine whether or not they meet the specifications. A large amount of testing of this kind is carried out for the Federal Government by the National Bureau of Standards. If the material meets the required tests this closes the transaction. If not, the procedure is repeated with the next lowest bidder.

It will thus be seen that in a transaction involving bids from perhaps a dozen manufacturers the product of only one or two is actually tested. This saves an enormous amount of time and labor, but gives little or no information about the relative value of the products of the various manufacturers. It does not tell which is the best. It says only that a product has been found which meets the specification-that it is good enough for the Government's requirements.

Some people have thought that because the National Bureau of Standards does a large amount of testing for the Government, it should be in a position to say which is the best of any group of products, or to arrange these products in order of excellence. It will be seen that the testing procedure actually followed does not give this information, and that the Bureau's knowledge of a whole line of competing products is necessarily very limited.

The Bureau has occasionally been urged to extend its tests to include whole lines of competing products, and to make the results of its tests available to consumers. The Bureau has neither authority nor funds to do this. Bills which would authorize work of this kind have been introduced in Congress, but they have never found congressional favor. Admittedly it would be a very costly undertaking, and would involve continuous testing on an enormous scale in order to report changes up or down in the quality of goods.

Since the use of specifications is not practicable for most of us who buy our goods over the counter, the Bureau has done what it could to encourage the use of a procedure which would secure for the over-thecounter buyer the advantage of quality specifications similar to those which the Government utilizes.

To the numerous requests from consumers, both organized and unorganized, for data concerning trade-branded goods tested at the National Bureau of Standards, the publication of which would be welcomed by many and opposed initially by few, we have given serious consideration. Our conclusion has been that, under the limitations imposed upon us, the best method of giving the public the benefit of our tests and investigations is to place the results of our research at the disposal of committees formulating nationally-recognized specifications and to encourage firms to manufacture goods to comply with these specifications, and purchasers to buy specification-made goods.

The Certification Plan. - The method employed by the Bureau in making available the essential information has been the development of the so-called "certification plan", which involves the compilation and distribution of lists of manufacturers desirous of obtaining contracts based upon certain selected nationally-recognized specifications, and willing, when requested to do so, to certify to the purchaser that the commodities delivered are guaranteed to comply with the requirements and tests of the specifications. This plan has been applied to 460 Federal specifications and commercial standards, more than 18,200 requests for listing having been received from about 
10,000 firms. Copies of these lists are sent to all interested tax-supported agencies and are available to others upon specific request.

The reception given to the certification plan by responsible manufacturers and representative trade associations has been very encouraging. It is being widely utilized by "public purchasers", that is, purchasers for the Federal, State, and municipal governments who are spending the money collected from the public in the form of taxes. It is also being welcomed by other large purchasers, the purchases of which are of such magnitude as to justify the use of specifications.

Many of the specifications to which the certification plan has been, or will be, applied cover commodities of much interest to over-thecounter buyers. Although it is not expected that such buyers will actually purchase commodities on individual specifications, some day they may be induced to confine their purchases of certain kinds of commodities to those known to be manufactured to comply with certain nationally-recognized specifications. They may even now be induced to examine critically such of these commodities as they do purchase to determine whether or not they are as represented and will comply with the buyer's individual requirements - to purchase on the basis of real quality and ability to meet service requirements rather than on the basis of superficial appearance or of the numerous kinds of sales arguments.

The Labeling Plan.- For the purpose of bringing to the attention of the over-the-counter buyer most effectively at the time of making purchases, such commodities as are manufactured to comply with nationally-recognized specifications, use is being made of a selfidentifying, quality-guaranteeing labeling plan which represents an important step in expanding the mass-production, mass-distribution, mass-consumption idea.

Experience in the use of self-identifying, quality-guaranteeing labels and correspondence relating thereto indicate strongly that it is possible to educate the public to look for quality labels.

In accordance with the self-identifying, quality-guaranteeing labeling system, a firm desiring to bring effectively to the attention of the over-the-counter buyer at the time of making a purchase, commodities which it is willing to guarantee as complying with the requirements of certain nationally-recognized specifications or standards, placed on the individual commodities or their containers labels which definitely identify both the specification and the manufacturer or the trade association which holds itself responsible for the guarantee.

Among the aims and objects of the self-identifying, qualityguaranteeing labeling plan are: (1) To assist the manufacturers and dealers in obtaining the maximum benefit to be realized from the mass-production, mass-distribution, and mass-consumption of such of their commodities as comply with the requirements of nationallyrecognized specifications; (2) to encourage the small-quantity overthe-counter buyer to purchase staple goods guaranteed to comply with such specifications; (3) to pass along to the over-the-counter buyer (the nonspecifications using public) some of the benefits derived by the contract buyer from using nationally-recognized specifications under the certification plan; and (4) to give to the individual consumers as well as the organized producers, the benefit of tests and investigations by placing the result of research at the disposal of committees formulating nationally-recognized specifications (which 
may or may not be those of the Federal Government) and encouraging firms to manufacture goods to comply with these specifications, and purchasers to buy specification-made goods.

Certain manufacturers have stated that they are now using or planning to use quality-guaranteeing labels, or their equivalent, with goods manufactured to comply with Federal specifications for brooms, dental alloys, dry cells, fireproof safes, gypsum, ink (writing, colored, and indelible), library paste, lime, linoleum, lumber, paint, paper (correspondence, carbon, blue print), pipe, portland cement, rope, soap. textiles, and wall board.

Attention is directed to the essential and significant features of the self-identifying, quality-guaranteeing labeling plan at the general conferences of the industries giving consideration to proposed commercial standards. Manufacturers desiring to do so are encouraged to identify by suitable labels such of their commodities as they are willing to guarantee as complying with certain designated commercial standards.

Through its contacts with organized and unorganized producers and distributors, and through cooperation with many groups of governmental and nongovernmental consumers, both contract and over-thecounter, the National Bureau of Standards can and does aid materially in determining the acceptability of certain standards to all interests concerned and in obtaining national recognition for standards that are accorded adequate acceptance.

The Chairman. I thank you, Dr. McAllister, for your instructive paper.

\section{DEMONSTRATIONS OF RECENT DEVELOPMENTS IN WEIGHING SCALES, BY REPRESENTATIVES OF MANUFACTURERS}

SeCRETaRy's Note.-At this point several manufacturers brought before the Conference samples of scales embodying new design features, and demonstrated them to those in attendance. Particular attention was given to the new features incorporated, the method of manipulation of the adjustments provided, and the answering of questions asked by members. As was the experience in former cases, it was found that many of the remarks made are of no value to a reader when a sample of the product is not before him, and thus no good purpose would be subserved in printing such material here. Consequently it has been decided to omit this material from the report.

It may be noted that such demonstrations as these, which familiarize the delegates with new apparatus, are of great interest and value to them. Attendance at the Conference is the only way in which full advantage can be obtained from program features such as this. The delegates were duly appreciative of the efforts of the manufacturers who took part in this demonstration.

\section{APPOINTMENT OF COMMITTEES}

The Chatrman. Now, gentlemen, the regular procedure is for the chair to appoint two of the Conference committees: The Nominating Committee and the Committee on Resolutions. So at this time, the Chair wishes to announce the following:

Committee on Nominations-J. C. Tinkey, of Ohio, chairman; $\mathrm{H}$. N. Davis of Vermont; Rollin E. Meek of Indiana; John S. Burke, of Jersey City, N. J.; and Howard E. Crawford, of Jacksonville, Fla. Committee on Resolutions.-C. D. Baucom, of North Carolina; John J. Levitt, of Illinois; George S. Barnard, of Michigan; Walter F. Stiles, of Connecticut; Alexander Hamilton, of New York, N. Y.; 
Wm. F. Steinel of Milwaukee, Wis.; and Jacob M. Vanderslice, of Philadelphia, Pa.

\section{ANNOUNCEMENTS}

(At this point the secretary announced that the report of the Committee on Specifications and Tolerances on modification of the code for vehicle tanks was available for distribution; also that the large-capacity scale-testing equipment of the department of weights, measures, and markets of the District of Columbia was parked outside the building, and that the delegates and guests were invited to inspect this equipment.)

(At this point, at 12:55 p. m., the Conference took a recess until 2 p. m.) 


\section{FOURTH SESSION-AFTERNOON OF WEDNESDAY, JUNE 5,}

1935

\section{TOUR OF THE LABORATORIES OF THE NATIONAL BUREAU OF STANDARDS}

(The afternoon session of the Conference consisted of a visit to the various laboratories of the National Bureau of Standards, particular attention being devoted to the Division of Weights and Measures. In order to make the trip of maximum interest and helpfulness, the delegates and guests of the Conference were divided into small groups, each group being in charge of a member of the staff of the Bureau.) 


\section{FIFTH SESSION-MORNING OF THURSDAY, JUNE 6, 1935}

(The Conference reassembled at 10:17 a.m., at the National Bureau of Standards, Mr. John P. McBride, presiding officer, in the chair.)

\section{RECONSIDERATION OF ADOPTION OF SPECIFICATION 9 FOR PERSON WEIGHERS}

The Chairman. Gentlemen, in relation to the action taken yesterday on the code covering person weighers, ${ }^{9}$ the decision of the Conference, as indicated by the vote taken, was that the whole code would be accepted as recommended by the committee. As you will recall, there was some discussion that occurred at various times in relation to specification 9 , as to whether that specification should be adopted as retroactive or as nonretroactive. Some confusion appears in the minds of those who were present as to which action was finally taken.

Now to clarify the situation and so that there may be no misunderstanding, the chair will entertain a motion to reconsider the vote of yesterday in relation to person weighers, so far as specification 9 is concerned. Having obtained that reconsideration, we may then take a positive vote on specification 9 . I think that we should do that so that the record will be unequivocal.

Mr. Griffith. Mr. Chairman, I will make that motion.

(The motion was seconded, the question was taken, and the motion was agreed to.)

The Chairman. We are now ready, gentlemen, for reconsideration of our vote in relation to specification 9, reading as follows:

9. A ticket person weigher shall be so designed and constructed that throughout a period when the supply of tickets is exhausted, any coin which is inserted will be returned to the user through automatic delivery to a suitable receptacle on the outside of the person weigher, or the insertion of a coin in the coin slot will automatically be prevented.

The question we want to settle is whether or not this section will be adopted to be retroactive or nonretroactive.

Now if someone will present a motion to the effect that this specification be retroactive or that it be nonretroactive, we can take a vote which will close that situation up at once.

Mr. Griffith. Mr. Chairman, we have been enforcing the code on person weighers since 1932 in our jurisdiction. We have found that one make of ticket person weigher does not contain a device to return the coin at the present time. The other scales are now equipped with a device to reject a coin or to make the scale inoperative when the tickets are exhausted.

In the particular scale in question a full supply of tickets numbers 10,000 , which is a very large supply. In the ordinary course of business, the operator or the sealer can readily discover when the supply is nearly exhausted, and the machine can be reequipped with

\footnotetext{
S See pp. 17-18, and 34-35.
} 
a supply of tickets. Our experience and records show that this seems to be taken care of.

I believe it will not be contrary to good administration to make this section nonretroactive. I therefore move you, Mr. Chairman, that specification 9 be made nonretroactive.

(The motion was seconded, the question was taken, and the motion was agreed to.)

\section{DEMONSTRATIONS OF RECENT DEVELOPMENTS IN WEIGHING} SCALES, BY REPRESENTATIVES OF MANUFACTURERS-Continued

(See secretary's note on page 46. At this point this program item was concluded.)

\section{NONTAX-PAID GASOLINE}

\section{By S. H. Wilson, Oil Chemist, State of Georgia}

A few years ago the tax-raising agencies of the various States decided to enter the then unexplored and, what has subsequently proven to be, most lucrative field of taxation, namely, that of petroleum products. Following this they almost immediately doubled, and in some instances trebled, the amount of tax levied per gallon, thus in many instances making the tax more than the product itself is worth at the point of production. Then and there they created the incentive for the gasoline bootlegger. I submit to you that when you create a condition such that a man can make as much as $\$ 500$ in the handling of one car of gasoline, by simply failing to do something that he did not want to do in the first place and something that he knows all of his competitors are required to do, you have a condition which none but the pure in heart can face without faltering. So we have the gasoline bootlegger and he, like all other bootleggers, has proven himself to be a most troublesome individual. In fact our efforts to subjugate him have been of such little effect that sometimes I fear that we are going to have to refer to him in somewhat the same language we use in referring to our poor, and say, "The bootlegger we have with us always."

All bootleggers are tax evaders, but not all tax evaders are bootleggers. They might be so termed under a broad interpretation of the word, but in my opinion the bootlegger is one who sells his products in violation of law and without regard for the quality of his goods - in fact, without regard for anything, his business being of a temporary or fly-by-night nature. The tax evader however, may have an established place of business and, although he is selling in violation of law, he may take a certain pride in the quality of his goods and in correct measure, with the idea of continuing in business for awhile, at least. It is this temporary character of business and the utter lack of responsibility together with inadequate and no doubt inaccurate measuring equipment, that makes the bootlegger of interest to the weights and measures officials.

In a short paper such as I am presenting to you at this time, it will not be possible to do more than approach the subject of tax evasion; and in doing this I am going to confine myself to outlining one or two of the tricks of the evader that have come under my observation in the enforcement of our regulatory law in Georgia. Before doing this, however, may I outline to you, briefly, the setup of our motor-fuel tax-collecting agency? 
We do not have many of the problems that I am sure some of the officials of other States are confronted with. For instance, we do not produce any petroleum; we have only one refinery, this being at Brunswick, and they are in sympathy with our law and cooperate with us whole-heartedly. We allow no tax exemptions, except to the Federal Government. All our wholesalers are bonded.

Common carriers are required, by law, to report to us all shipments of gasoline; in addition to this the refinery must report all shipments to our State. It is obvious, however, that we cannot enforce this latter provision strictly as these refineries are out of our jurisdiction, so we do not attempt to do it by force, but by asking for it and by being nice about it. We require all wholesale dealers in our State who receive shipments, to report them to us. Thus, you see, we have a three-way check on all shipments coming into our State and we have found by experience that the carriers, that is the railroad companies, are the most accurate. It is hard to find an instance where all three of these agencies fail to report a particular shipment at the same time. This gives us a starting point for tracing any car that might be in question.

Under our regulatory law, whenever a shipment is received in our State, the dealer, before unloading, must draw a sample of the product received and submit it with all data, such as refiner, car initials, car number, number of gallons, etc., to the laboratory for analysis. Then, we have six inspectors traveling over the State, drawing samples and inspecting pumps. These men make daily reports to the laboratory. We have two clerks, one who checks gallons received in the State and the other checking tax-paid gallonage. One auditor in our immediate office and a corps of men from the State auditor's office check all delinquent taxes. Still in spite of all this we have some tax evasion. A large percentage of this can be accounted for, as follows. When our law was enacted, the various counties and most municipalities were buying gasoline in tank car lots. They claimed, at that time, that they were exempt and refused to pay the tax. Litigation was started to clear the matter up, but it took time to put it through. In the meantime, buying continued so that when we did finally get a favorable decision large sums of money were owing the State and we have found it difficult, in some instances, to make collections.

In the enforcenent of our regulatory law we sometimes find it necessary to condemn a car of gasoline or kerosene on account of failure to meet our specifications. The cars have not been unloaded and are technically still in possession of the refinery. We allow the refinery to withdraw such a car from our State. We, of course, trace the movement of this condemned car through the railroad records in order to see that it is taken out of the State. We have found instances where dealers have tried to take advantage of this situation, in order to evade taxes. I recall one such instance. A car of gasoline had been condemned and ordered shipped out of the State. The dealer came in a few days later, apparently all excited and told this story. "You remember that car you condemned for me the other day?" I replied that I did. "Well," he said, "this morning while I was away from my place the railroad picked it up." "Well", I said, "what did they do with it?" "They have already shipped it out." I asked him $\dot{i}_{f}$ he unloaded it before they pulled it and he said "No, absolutely, $i_{t}$ went out full, just as it came in." In taking the matter up with the 
railroad, it developed that the car had been gone several days and that the railroad company insisted that the car went out empty. We finally obtained permission from the proper authorities to have the car stopped and inspected and it, of course, was found to be empty.

Another instance of a little different form of evasion is, when a dealer buys a car of inflammable distillate and does not report it or submit a sample from the car before unloading, claiming that the law only requires him to submit data and samples on gasoline and kerosene. This distillate, which, of course, is a naphtha, is worked off gradually in his gasoline. Thus, you see if he gets away with it, he picks up another car of gasoline, tax free.

Then we have the dealer who runs several stations, one of which is near the State line. He is selling in both States and paying taxes in both States. Then one day he loads at the border station and reports to his State that he is delivering to a neighboring State and claims exemption, when, in fact, he is delivering to one of his own stations, thus evading the tax unless eventually caught through the interchange of information between these two States. In Georgia, the dealer pays tax on what he sells and not on the amount he buys. This makes it difficult in some instances to determine what a dealer owes and make it possible for one to carry on a practice such as I have outlined.

One of the most difficult problems that we are having to deal with now is the tractor-fuel problem. In defining motor fuel for taxation, our law names certain substances and then continues, "but shall not include any such product which has an initial boiling point of over $200^{\circ} \mathrm{F}$, when determined by the distillation method as prescribed in United States Bureau of Mines Technical Paper 323 B." Dealers are now bringing in tractor fuel with initial boiling points of 205 to $210^{\circ} \mathrm{F}$, and end points of 325 to $360^{\circ} \mathrm{F}$. These special products, in some instances, have a gravity of 58 API. They are nontaxable, but you can see the possibilities in the hands of an unscrupulous dealer.

The problem of dealing with tax evasion is becoming more difficult as the improvement of roads and motor vehicles go hand in hand in making it possible to move large gallonage over long distances by motor trucks.

I am told that 90 percent of all bootlegging is done at night. There is an understanding between the bootlegger and the dealer, and the latter knows, of course, about when the bootlegger is coming. If such a dealer wants gasoline delivered, he leaves a light in the station as the proper signal and then also leaves the filler pipe unlocked. The delivery is made while the attendant is at home in bed and settlement is made later.

Gasoline is being trucked into Georgia from various ports in Florida. From the refinery at Mobile, gas moves by small barges to such points as Freeport and St. Marks, and later by motor to various points in our State. Shipments also come of course, from marine terminals at Jacksonville. The longest haul, however, that has come to light, up to the present time, was from Bowling Green, Ky. This was a bootlegging proposition and was promptly brought to light and stopped through the enforcement of our regulatory law, the gasoline failing to meet our specifications. The dealer was caught with a considerable 
gallonage on hand. We permitted him to move this gasoline from the State, but required a receipt from the purchaser. Some of the gas was returned to the refinery and receipted for by them. However, quite a bit of it went into the hands of that distinguished legal personage, John Doe, who at that time seemed to have been a resident of the State of Alabama.

If I may be permitted to do so, I would recommend, in order to discourage bootlegging as much as possible, that the tax-collecting agency be a part of, or closely associated with, the regulatory unit of each State. By such arrangement, information with reference to the character of any product in question, and other information such as the condemnation or withholding from sale of any lot, is immediately known to the tax officer.

Auditors should stick all storage tanks at the time of making the initial audit in order to have a definite starting point and then should work continuously from this point.

There should be an interchange of information each month between adjoining States. Laws should be enacted prohibiting the delivery of taxable petroleum products to the retailer after certain hours at night and before certain hours in the morning. All trucks engaged in the transportation of such products should be compelled to register with the tax collector and drivers of such trucks should have papers showing all necessary information with reference to any particular load. Prominent highways leading from one State to another should be patrolled.

All dealers should be bonded and bonds should be forfeited-thus promptly putting the offender out of business-when he fails to pay taxes as a result of dealing with questionable characters. Eternal vigilance is the watchword if you are going to make the business of the gasoline bootlegger unprofitable in your State.

The Chairman. Thank you, Mr. Wilson.

\section{REPORT OF SPECIAL COMMITTEE ON RESOLUTIONS, PRESENTED BY WALTER G. WHITE}

Your committee reports a special resolution and moves its adoption.

\section{IN MEMORY OF JOHN H. AUSTIN, OF MAINE}

Whereas as a result of the untimely and unfortunate accident, causing the death of our respected coworker from the State of Maine, Mr. John H. Austin, a cloud of sorrow has been cast over this conference, and

Whereas due to the great distance traveled by many of our members, it is impossible to close this convention as a fitting tribute of our deepest regret, and

Whereas it is the wish of this convention to express to the family and the weights and measures department of the State of Maine, our sincere sympathy in their bereavement at the loss of loving husband, father, and respected official: Therefore be it

Resolved, That this body, in convention assembled at Washington, D. C., this sixth day of June, one thousand nine hundred thirty-five, do unanimously adopt this resolution and have it spread upon the minutes; and be it further

Resolved, That a copy of this resolution be forwarded to the family of John H. Austin and the Department of Weights and Measures of the State of Maine.

(The resolution was duly adopted.) 


\section{TEMPERATURE OF GASOLINE IN UNDERGROUND STORAGE}

By B. W. Ragland, Chief, Bureau of Weights and Measures, Richmond, Va.

Mr. Chairman, ladies, and gentlemen, one of the duties of the Richmond bureau of weights and measures is the supervision of motor-fuel deliveries both as to quantity and quality. This inspection does not cost the taxpayer a cent and helps pay the operating expenses of the weights and measures division. The cost per capita for services renciered to the buying public is less than a 3-cent postage stamp.

We are often asked, "How can you do this vast amount of work at such a low cost?" It is against the laws of Virginia to charge a fee for testing weighing and measuring devices, but not against the law to charge a fee for testing the quality of various commodities. We charge a fee, based on the amount of motor fuel brought into the city. Last year we tested samples representing 109,668,030 gallons of fuel. These duties naturally brought to our attention the methods used by the several oil companies in the delivery of their products to the service stations.

The large number of service-station operators complaining of a supposed shortage in these deliveries made us feel that there was something wrong. As we require all delivery trucks to be marked with the shell capacity of the several compartments on both sides of each dome and knowing that service stations had the privilege of checking these deliveries, we looked for the cause of these complaints from other sources. We noticed that all of these complaints originated from service stations served by major oil companies who used gage sticks for fixing inventories. Frequently the shortage amounted to $\$ 20$ per inventory.

The question of temperature was offered as the cause of the trouble. We determined to see just what part the temperature of the underground tank played in this supposed shortage. A 9-week period of our average weather conditions was selected to determine if $\mathrm{Mr}$. Service Station Dealer was the loser or gainer when he received his motor fuel from the oil company's tank wagon.

Normal summer temperatures were taken advantage of, as well as extremely low winter temperatures in order that no condition which might cause a loss or gain might be overlooked. Extreme summer temperatures were taken into consideration and a thorough check made of the underground-tank temperatures. In this location, when the atmospheric temperatures are high, underground temperatures are also high, and in many cases higher than the atmospheric temperatures. As an example of this, we found the atmospheric temperatures to be $70^{\circ} \mathrm{F}$, and the underground temperatures to be as high as $80^{\circ} \mathrm{F}$, in several tests made. This condition would not cause the supposed summer loss due to the temperature but, on the contrary, would cause a gain to the service station.

We first took the temperature at the bulk plant, then proceeded to accompany the truck to the point of delivery where the temperature was again taken of the motor fuel in the tank. The temperature was then taken of the fuel in the underground tank. The delivery of fuel was then made and again the temperature was taken of the underground tank at the completion of delivery. The following data sheet gives a picture of what Richmond, Va., finds to be the true case. Loss or gain, which? 


\begin{tabular}{|c|c|c|c|c|c|c|c|c|c|}
\hline \multirow[b]{2}{*}{ Date } & \multirow[b]{2}{*}{$\begin{array}{c}\text { Time } \\
\text { (a.m.) }\end{array}$} & \multirow{2}{*}{$\begin{array}{l}\text { Tem- } \\
\text { pera- } \\
\text { ture of } \\
\text { air }\end{array}$} & \multirow[b]{2}{*}{ Weather } & \multicolumn{3}{|c|}{ Temperature of- } & \multicolumn{2}{|c|}{ Fuel in ground tank } & \multirow{2}{*}{$\begin{array}{l}\text { Service-sta- } \\
\text { tion fuel loss } \\
\text { or gain due } \\
\text { to difference } \\
\text { in tempera- } \\
\text { ture between } \\
\text { wagon and } \\
\text { ground tank }\end{array}$} \\
\hline & & & & $\begin{array}{l}\text { Tank } \\
\text { wagon } \\
\text { at time } \\
\text { of de- } \\
\text { livery }\end{array}$ & $\begin{array}{c}\text { Ground } \\
\text { tank } \\
\text { before } \\
\text { filling }\end{array}$ & $\begin{array}{l}\text { Ground } \\
\text { tank } \\
\text { anter } \\
\text { filling }\end{array}$ & $\begin{array}{l}\text { Before } \\
\text { filling }\end{array}$ & $\begin{array}{l}\text { After } \\
\text { filling }\end{array}$ & \\
\hline 1931 & & ${ }^{\circ} \mathrm{F}$ & & ${ }^{\circ} \mathrm{F}$ & ${ }^{\circ} \mathrm{F}$ & ${ }^{\circ} \mathrm{F}$ & Gallons & Gallons & Gallons \\
\hline Oct. 11 & 10:00 & 70 & Clear -- & 74 & 75 & 76 & 125 & 725 & +0.72 \\
\hline & 10:00 & 63 & -...do- & 66 & 70 & 68 & 280 & $\begin{array}{l}028 \\
551\end{array}$ & +.3 \\
\hline & 10: & 49 & -_-_do_. & 59 & 66 & 62 & 18 & 473 & +.52 \\
\hline Nov. 6 & 10: & 57 & -...do- & 59 & 69 & 62 & 35 & 1,000 & +1.17 \\
\hline 13 & $10:(4)-\left(\begin{array}{ll}10 \\
10\end{array}\right.$ & 37 & do. & 46 & 57 & 57 & 477 & $\begin{array}{l}735 \\
326\end{array}$ & $\begin{array}{l}+1.65 \\
+\quad 24\end{array}$ \\
\hline & 10: & 68 & Bain & 58 & 62 & 60 & & 326 & +.24 \\
\hline Dec. 12 & & 46 & & $\begin{array}{l}50 \\
42\end{array}$ & 59 & 57 & & & $\begin{array}{r}+.69 \\
+1.51\end{array}$ \\
\hline & & & & & & & & & \\
\hline
\end{tabular}

[NOTE.-The distance of haul on which data were based was 0.8 to 5 miles]

On tank-car deliveries the oil distributors make the necessary temperature correction, the transfer being made on the accepted basis of $60^{\circ} \mathrm{F}$. The loss or gain on a smaller delivery is so slight that it is a matter of little concern.

We believe the chief cause of nearly all the complaints in Richmond was due to the abominable gage stick. Authorities admit the best hoped for when using the gage stick is approximation. Our bureau refuses to approve it, and therefore does not seal them. The Virginia weights and measures law prohibits the use of unsealed weights or measures. All oil companies in Richmond have stopped the use of these gage sticks as a method of fixing inventories, and complaints as to short deliveries have stopped.

The Chairman. Thank you, Mr. Ragland.

Mr. Waldmax. Would the depth of the tank have anything to do with the temperature?

Mr. RAgland. In Richmond we require tanks to be put in 6 feet deep. They have a three-foot clearance above the top. All of our tanks are supposed to be put in identically the same.

\section{GASOLINE LOSSES IN STORAGE AND HANDLING}

\section{By H. C. Dickinson, National Bureau of Standards}

Mr. Chairman, ladies, and gentlemen, gasoline differs from most of the products which are measured or weighed in that some of it can escape by evaporation in the process of handling. This is further complicated by the fact that the volume of the gasoline changes considerably with change of temperature. Thus the accurate measurement of gasoline by volume presents difficulties which are not generally very well understood and lead to controversy on points which could be readily settled if the facts were known.

In matters of measurement as such, you are so much better informed than the writer that we shall assume in this discussion that the measuring and weighing devices used are correct, and shall deal only with those factors which either account for real losses of gasoline or for apparent losses or gains despite the correctness of the measuring devices themselves.

Evaporation Losses.-Losses of gasoline by evaporation take place whenever gasoline is exposed to the air. Such conditions, however, 
are so carefully avoided for the sake of safety in the usual methods of handling gasoline that we need not discuss the matter here. In any case such losses are so variable as to be beyond any reasonable estimate.

This leaves for consideration the losses which may occur in storage tanks or in the filling and emptying of them. Such losses will depend on: (1) The vapor pressure of the gasoline, which differs considerably among commercial products; (2) the temperature within the storage tank; (3) the volume of the open space in the tank above the gasoline; and (4) the amount of air circulation into and out of the tank.

Gasoline is a mixture of volatile fractions of petroleum. The usual product has a flash point which is not commonly measured because it is much below ordinary atmospheric temperature. The flash point is that temperature at which a sufficient amount of the product will evaporate to form an explosive mixture with air. Ordinary commercial motor gasoline will produce explosive vapors at all ordinary temperatures. This is one of the important elements in the problem of safety. Gasoline vapor is practically always explosive in the open air, but not so in closed tanks.

A more significant test than the flash point which is commonly applied to gasoline is the Reid vapor-pressure test, originally designed to indicate safety of handling the product in closed containers. This test shows approximately what pressure the gasoline vapor would exert if a tank one-fourth full of liquid gasoline were heated to $100^{\circ} \mathrm{F}$. For commercial gasolines this pressure may range from 8 to 12 pounds per square inch. Gasoline having a vapor pressure of 8 pounds or less is generally suitable for use in hot weather, while those of higher pressures are generally marketed in cool or cold weather. The trade practice in this respect is controlled by the tendency of too volatile gasoline to "vapor lock" or form vapor in the fuel systems of automobiles and cause stoppage or irregular behavior of the engine.

It should be noted that the Reid vapor pressures indicated by test are the pressures produced by the gasoline vapor and do not include the normal atmospheric pressure of about 15 pounds per square inch. Thus, if the vapor pressure were 15 pounds by this test, the gasoline in question would begin to boil at about $100^{\circ} \mathrm{F}$ where the pressure produced by its vapor equaled the atmospheric pressure.

Vapor-pressure measurements make it possible to calculate some of the losses of gasoline vapor which take place under varied conditions of handling.

If gasoline partially fills any vented tank and remains at a constant temperature below its boiling point, i. e., below 100 to $150^{\circ} \mathrm{F}$. and at a constant barometric pressure evaporation will occur as follows: Gradually a sufficient amount will evaporate to saturate the air originally in the container above the gasoline. In this process the air and vapor will expand somewhat and a small part of the mixture will escape by way of the vent.

When equilibrium has been reached, there will be no further escape of gasoline vapor, except such as takes place by quiet diffusion from the end of the vent pipe. If the vent is as small as practicable, losses of gasoline under these conditions are extremely low, in fact usually negligible.

However, constant temperature and barometric pressure are not to be expected. If the temperature rises, an additional amount of 
gasoline will evaporate and force some of the vapor and air out of the vent by a slight increase in pressure. If the temperature falls the contraction in volume of gases in the tank will draw in fresh air which in turn will be saturated with vapor. Therefore, fluctuating temperatures will result in a gradual loss of vapor from a partly filled tank. These losses will be somewhat proportional to the volume of vapor space in the tank. A tank nearly full will lose much less than one which is nearly empty.

Losses of this kind in a vented tank above ground may be largely due to large daily changes in temperature. For underground storage tanks these changes are probably negligible, except for the effect of filling with fresh supplies at different temperature. However, changes in barometric pressure have much the same effect. When the barometer rises fresh air is forced in to the tank and when it falls some of the vapor-air mixture is forced out. Here again the loss is proportional to the vapor space, and a full tank suffers only slight losses. Such losses occur in both underground and exposed tanks.

Another source of loss of gasoline vapor is the operation of filling with a new supply. Assume a 1,000-gallon tank nearly empty. It will contain from 1 to 3 gallons of gasoline in the form of vapor depending on the temperature of the residue of gasoline. If this tank is filled with 1,000 gallons of fresh gasoline the vapor is forced out of the vent and lost. This loss, though small, appears to be a distinct and practically unavoidable loss of material. At each new filling of a tank, a small percentage (anything up to about 0.5 percent) of the previous tankfull is wasted.

Thermal Expansion Losses.-The changes in volume of gasoline with changes of temperature result in apparent losses and gains in the amounts of gasoline which can be taken out of tanks which contain presumably the same amount. These are not real losses of gasoline but changes in the amounts sold due to changes in the actual volume of the product as withdrawn from storage.

This comes about through the fact that gasoline as delivered to the underground tanks of the filling station comes in tank wagons which are often filled from above-ground tanks. The gasoline is at about the temperature of the outside air. This gasoline goes into an underground tank which keeps about the same temperature winter and summer. Consequently, the supply of gasoline which is measured as, say, 1,000 gallons, at a temperature anywhere from 0 to $100^{\circ}$ $\mathrm{F}$, shortly changes its temperature to that of the underground tank which may be from 50 to $60^{\circ} \mathrm{F}$ and practically constant throughout the year. Accordingly, a given amount of gasoline correctly measured as to volume, will change in volume with the change in temperature and the amount measured out of the tank will differ from that measured into it by some 1 percent for each $15^{\circ}$ change in temperature.

There will be an apparent loss of gasoline in summer when the product is delivered to the service station warm and cooled in the storage tank, and an apparent gain in winter when the tank wagon deliveries are colder than the storage tank. On the year's business therefore the filling station should just about break even so far as thermal expansion and contraction of gasoline are concerned. To be sure, if a large preponderance of the business is done in summer, there will 
be a small net loss in the gallonage marketed and vice versa if the winter season is the busy one.

Safety.-One may scarcely omit some consideration of safety in relation to the handling of gasoline. Considering the hazard presented by the use in large quantities of a product having such inherent sources of danger, it is surprising how few serious explosions or fires have resulted from the general marketing of gasoline. Unfortunately, the same cannot be said for its random use by individuals.

From a safety standpoint, volatility renders gasoline hazardous when exposed to the air in any inclosed or poorly ventilated space, as a mixture of vapor and air may be formed which is capable of violent explosion. The explosive energy which can be thus produced in, say, a small room of 1,000 cubic feet, exceeds that of 50 pounds of smokeless powder. On the other hand, the probability of producing a mixture of this sort is rather remote. Gasoline vapors mixed with air are explosive only over a rather narrow range. If less than about 0.5 percent, or more than about 6 percent of gasoline vapor by volume is present in the air, the mixture cannot be ignited.

Violent explosions will occur only for mixtures well within these limits. Thus if a gasoline tank contains considerable liquid which has been there for some time, or has been well agitated, the mixture of air and vapor above the liquid will be far too rich to explode. It. will, of course, burn quietly if exposed to outside air and ignited. On the other hand, if a tank is nearly empty so that there are not enough light portions of the gasoline to saturate the air a violently explosive mixture may be formed.

The same may happen if fresh air has been admitted to a tank by rapidly withdrawing gasoline from the bottom. An explosive mixture also might occur in a tank at very low temperatures when the vapor pressure of the gasoline is much less than ordinary. There is in general only one means whereby dangerously explosive mixtures of gasoline vapor and air can be produced quickly, that is by the sudden spraying or spilling of considerable amounts of gasoline into the air. Explosions of such mixtures have occurred at times when a pool of gasoline has collected near the intake to a carburetor on a boat or motor car engine, and a back fire has suddenly distributed the liquid in a fine spray which could quickly evaporate and mix with the air. Such an explosion may readily wreck an entire building if enclosed.

In general, the handling of gasoline with entire safety requires knowledge of the volatility of the product and of the conditions under which the vapors can mix with air, as well as practical experience and eternal vigilance. Fortunately, it is only on rare occasions that the worst results occur, but for this very reason users of gasoline are liable to become careless, since dangerous practices may be repeated hundreds of times without accident.

General Considerations.-In the handling of gasoline at the present time, losses due to evaporation must be considered as normal. In underground storage, all losses due to evaporation should not exceed 1 percent and are usually not more than 0.5 percent of the total gallonage handled. With exposed storage tanks, the evaporation losses may range from 1 to 2 percent. In the case of the retail operator, there are volume losses in hot weather and volume gains in cold weather due to thermal expansion of the gasoline. 
For any particular dealer, whether large or small, it should be practicable to arrive at a figure representing normal losses for his particular operations and equipment, by carefully kept records over a period of several weeks at various seasons of the year. If the losses so arrived at appear excessive, attention should be directed toward errors in measuring devices or toward possible leaks in storage tanks and accessory piping.

The safe handling of gasoline requires a knowledge of its behavior under various conditions where explosive vapors may be formed. Fortunately, the general technique of wholesale distribution and marketing to private users is a remarkably safe procedure. The miscellaneous handling of gasoline by unskilled persons is hazardous.

Mr. Benbe. Mr. Chairman, will there be any of these papers available for distribution, particularly Dr. Dickinson's?

The Chairman. I think we have mimeographed copies of Dr. Dickinson's paper.

Mr. HoLBRook. Dr. Dickinson, if there is a supply of your circular letter in relation to this subject available, will you have a number of them delivered here this afternoon?

Dr. Dickinson. All right.

The Charrman. I want to thank you, Dr. Dickinson, and I think the delegates appreciate your address this morning. If it can be given to us in permanent form it will be very much worth while.

\section{REPORT OF COMMITTEE ON SPECIFICATIONS AND TOLERANCES ON MODIFICATION OF SEVERAL CODES, PRESENTED BY F. S. HOLBROOK, CHAIRMAN}

\section{Presented by F. S. HolвRook, Chairman}

Mr. Chairman and gentlemen, this report will cover items in a number of codes, in which your committee feels that some amendment or modification is necessary.

The nature of these recommendations is such that it seems we will get along more rapidly if we discuss, and adopt or reject, each proposed amendment as we reach it, rather than to postpone action until the report as a whole is before you.

I presume each of you has a copy of this report in your hands; if not, there is a supply available.

The first suggestion your committee offers is in relation to specification 2, under the heading "Liquid Capacity Measures." This specification now reads as follows:

2. Liquid measures of the customary system shall be of one of the following capacities only: 1 gallon, a multiple of the gallon, or a binary submultiple of the gallon, that is, a measure obtained by dividing the gallon by the number 2 or by a power of the number 2: Provided, however, That nothing in this specification shall be construed to prevent the use of cans for ice cream, exclusively, in the $21 / 2$-gallon (10-quart) size, but only when having an inside diameter of not less than $8 \frac{1}{2}$ inches, or of brick molds for ice cream, exclusively, in 5-pint and 3-pint sizes, or of bottles for milk or cream in the 3-pint size.

The recommendation of your committee is that the last clause of the specification reading:

or of bottles for milk or cream in the 3-pint size

be stricken out.

Your committee believes that our normal system of permissible sizes of measures should be rigidly adhered to, and consequently the 
committee has resolutely set its face against the introduction of such odd sizes as 5-, 6-, and 7-quart measures, one-third and two-third pound weights, and various other sizes, which we have been requested from time to time to recognize in the specifications. Such odd sizes when used for commercial weighing or measuring purposes would facilitate the perpetration of fraud and are likely to be the cause of mistakes, since a user may, by intention or otherwise, select the wrong size measure or weight, when many sizes differing only slightly from each other are available. Your committee feels that the 3-pint milk bottle is a departure from the usually recognized sizes in our measuring system. The 3-pint measure for other uses, is not recognized. To be consistent, we feel that the 3-pint milk bottle should be stricken from the code. It appears that no hardship will be caused thereby, because, although the 3-pint size has been recognized for a great many years, few or none of them have, according to our understanding, ever come into use.

Mr. Ragland. Mr. Chairman, I move we accept the recommendation of the committee.

(The motion was seconded.)

Mr. RICHARDS. This wouldn't affect the 3-pint milk bottles now on the market, of course?

The Chairman. In the various States in which this size is authorized by statute, they would have a right to continue, I understand.

Mr. Richards. If they are now permitted without specific recognition in a State law, would they immediately be taken out?

The Chairman. Mr. Holbrook will answer that question.

Mr. HoLBrook. Normally, we certainly should not condemn 3pint milk bottles which have come into use during the life of this specification. It would, of course, be very difficult to identify milk bottles which are in use at the time this amendment takes effect, on account of the difficulty of marking milk bottles. However, in view of the fact that the specification has recognized this size for many years, I would be inclined to include in the recommendation of the committee that this specification be nonretroactive. The 3-pint milk bottles now in use-I think the number is very small-should be allowed to remain in use until normally retired, by breakage or otherwise. The life of a milk bottle is not a very long one, at best.

Mr. Baucom. Mr. Chairman, the question came up in my State some time back and we doubted whether the 3-pint was constitutional. We accordingly did not include this size in the regulation which we promulgated.

Some jurisdictions have recognized the third-quart milk bottle. I think this size ought to be gotten rid of; we ought to outlaw them. I am afraid as drawn here, that under this specification we won't get rid of them.

(The question was taken, and the motion was agreed to.) ${ }^{10}$

The Chairman. Gentlemen, we now have the distinct honor and pleasure of having with us the Honorable John Dickinson, Assistant Secretary of Commerce. I am very much pleased to introduce the Honorable John Dickinson.

10 The consideration of this report was resumed at the seventh session. See pp. 99 and 103. 


\section{ADDRESS BY HON. JOHN DICKINSON, ASSISTANT SECRETARY OF COMMERCE}

Ladies and gentlemen, I have no intention whatever of interrupting your proceedings here, but in the absence of Secretary Roper, who is now on the west coast, I wanted to come out here as the acting head of the Department of Commerce, and express my appreciation to you gentlemen for the cooperation with which you are working with our Department.

The Department of Commerce, of course, has numerous activities, activities in connection with fisheries, activities in connection with foreign trade, and in connection with shipping, but not the least among its activities are those conducted here at the National Bureau of Standards; and I want all those who have contact with the National Bureau of Standards, and who are working and cooperating with it, to realize that the Department as a whole, and the chief executive. officers of the Department are very much interested in keeping in touch with the work of the National Bureau of Standards, and of giving what assistance we can, not merely to the National Bureau of Standards, but, as I said, to all of those who are working and cooperating with the National Bureau of Standards.

One more word, and that is as to the nature of this Conference in which you are engaged. It seems to me to be a very significant thing, and to hold out, in some respects, a suggestion for the solution of many of the difficulties, and they are difficulties, of our dual form of government. There should be a cooperation of this kind between the State officials and the officials of the departments of the Federal Govermment, which deal with the same subject matter.

The problems of the Federal Government and the State officials, as you realize, are conflicting. The main outlines, of course, are sketched in the Constitution, but the Constitution does not go into detail, and consequently in carrying out all of the details there are bound to be differences. We must find where the lines between the Federal Government and the State powers come. Those differences are not very likely to be raised if the Federal power and the State power work hand in hand and step by step in a cooperative manner. I am not one of those attempting to take something away from the other fellow. I know that is not what you are doing, and that you are working in the opposite direction from that.

The Constitution entrusted to the Federal Government the standards of weights and measures, but, on the other hand, it would be unwise and inconvenient for the Federal Government to undertake to build up on the basis of a doubtful constitutional grant of power, a mechanism of its own.

It is highly proper that the details of weights and measures should not be in the hands of the Federal Government, but in the hands of local people, without, of course, involving the national uniformity of activities. So, this National Bureau of Standards and the State officials both have to do with weights and measures; we have a model system on this subject, and the Federal Government and the State officials are cooperating in the matter. It might very well be extended to other fields.

The manifold lines of policy are laid down by Congress, but Congress has failed to give us the details of weights and measures. The 
application of those standards are all administrative, and all of the details, and the making of regulations are matters in the control of States in which you are cooperating with the Federal Government. It is you upon whom the burden of the work falls, of course, as State officials. So that is the situation regarding this subject and you are acting in harmony with the Federal Government in giving effect to these matters.

I want to express my appreciation of your leading. You are giving your services to the Federal Government, and the Federal Government is putting their services at your disposal. This may well be a very happy goal in other fields and in this particular field it is absolutely essential.

I am very glad indeed to have had the opportunity to be here and to be able to tell you of this branch of the Federal Government, and that it depends, of course, on your cooperation.

I thank you.

The Chairman. Thank you, Mr. Secretary.

\section{WEIGHTS AND MEASURES AND PETROLEUM PRODUCTS}

\section{By D. V. Stroop, Secretary, Division of Marketing, American Petroleum Institute}

Mr. Chairman, members, and guests of the conference, oil companies, by their advertising, have made costly investments in good will of the motoring public toward their products. They cannot and will not jeopardize their investments in goodwill by permitting these customers to receive short weight or short measure in their purchases. The problem of preventing such short weights and short measures is of mutual concern to you, the sealers of weights and measures, to us, the marketers of petroleum products, and to the manufacturers of measuring devices. You are in duty bound to protect the public against fraud while we are employed to give our customers what they purchase. The equipment manufacturers provide the means whereby our aims may be accomplished. There can be no differences in opinion between us as to the principle that purchasers of petroleum products must receive in full the quantity of products purchased. But in the past, and possibly in the future, there have been and may be differences of opinion as to how the principle may best be applied and the result accomplished. We could not presume to tell you anything regarding your problems or the methods you apply to their solution; however, we welcome this opportunity to give you some idea as to our problems in connection with the delivery of full measure in the sale of petroleum products.

There are some thirty-odd integrated oil companies whose products are sold at more than 200,000 retail outlets. All of these companies, which make substantial investments to gain the good will of the public, own retail outlets, but these total probably less than 14 percent of the total number of stations at which their gasoline is sold today.

Based upon the recent report of the special subcommittee of the House of Representatives Committee on Interstate and Foreign Commerce, it may be estimated in round numbers that approximately $15,000,000,000$ gallons of gasoline will be sold this year to more than $25,000,000$ consumers. This amounts to an average of about 600 gallons per customer. 
For the sake of definiteness we may say that these consumers will purchase the bulk of this gasoline at some 250,000 retail stations. On this basis each station has an average potential market for 60,000 gallons of gasoline per year, or 5,000 gallons per month, or about 165 gallons per day.

It may be estimated that at least 750,000 gasoline dispensing pumps are used in the delivery of this gasoline. If this figure is used, the average pump delivers only about 55 gallons per day, which explains why a motorist seldom experiences delay in making a purchase of gasoline for his car. From this you may realize the tremendous problem the industry has to bear in the maintenance of gasoline dispensing pumps, and because of the relatively small quantity delivered per pump you can realize the desire of industry to minimize expenditures on such equipment. This factor influences the industry to favor a pump which will require a minimum amount of maintenance, repair, and reconstruction. Mechanisms must be simple, rugged, and dependable.

The equipment will be operated by all types and classes of people, who, in the main, will be none too careful in the way it is used. Some of it may be operated by persons who will be tempted to use it dishonestly. This temptation undoubtedly can be fostered by high taxes on gasoline where a seller may greatly increase his profit by short-measuring his customers. In fact, the imposition of disproportionately high taxes on gasoline creates an unhealthy moral temptation for personal gain though either tax evasion or short delivery.

Such a situation is fraught with much danger of loss of public good will toward the oil companies which advertise the economy of their products. A short delivery means reduced mileage per gallon and the consumer is more likely to blame the mileage reduction on the quality of the fuel rather than upon a deficiency in the quantity purchased. He depends upon you, his sealers of weights and measures, to protect him against short measure. You, in turn, may be tempted to ask us for a fool- and fraud-proof pump. We, in turn, cannot justify the expenditures necessary to provide such equipment, even if such is available.

Consider for a moment the sale of lubricants. On an average a retail station may sell about 3 gallons of lubricating oil per day. Certainly such small-volume business can justify only a minimum of expenditure for the prevention of short-measure delivery.

It isn't the cost of the product which demands conservation in such expenditures, it is the cost of complicated measuring equipment, its maintenance, its repair, and its replacement, which dictates the apparent reluctance of oil companies to meet some change in specifications and tolerances on measuring dimensions. Dispensing equipment for petroleum products rarely has an opportunity to wear out. Obsolescence in one or more of many forms usually relegates the equipment to the scrap heap. Changing weights and measures requirements has been a most effective factor in obsolescence, even of equipment still capable of delivering full honest measure.

A third product sold to consumers is automotive gear lubricant. The sale of this at the average retail station probably does not exceed 3 pints per day. Here again the limited volume of sales calls for strict economy in expenditures for dispensing equipment. The situ- 
ation is complicated by recent developments in the construction of automotive equipment because of the necessity for dispensing a number of different grades and classes of lubicant. Some stations have found it necessary to supply as many as five difierent grades of lubricant. You can realize the industry's reluctance to purchase a relatively expensive metering device which, on the average, will be called ubon to measure less than a pint of a product per day.

Even this does not tell the whole story, because the sale of gear lubricant and, to a lesser extent, the sale of lubricating oil, includes a servicing factor. A greasing pit or lift must be provided. The gear housing or crankcase may require cleaning, flushing, and refilling. Frequently the expense of servicing may exceed the price received for the products.

When we patronize a meat market to purchase a roast, we expect to pay for the services of the butcher, in addition to the meat we buy. Possibly our roast will include a considerable weight of bone. Both the meat and the bone will be delivered to us or, upon our request, the butcher will remove the bone and bind up the roast. Usually if the bone is removed it will be left in the market, even though it has been paid for in purchasing the meat.

When a customer purchases a pint or a quart of lubricant he requests delivery either in a portable container or in a housing or crankcase of his car. The delivery of the lubricant into the proper part of the car involves additional service. This service element is variable and cannot readily be evaluated, it must be averaged. The quantity of product delivered is measurable and should be measured, but the tolerances on such measurements, in all fairness, should be of a nature which will permit the use of simple and inexpensive equipment. Surely it seems difficult to justify a requirement for a narrow tolerance and relatively elaborate mechanisms for the measurement of a material, the price of which represents a considerable charge for service.

This brief paper gives a sketchy picture of some phases of our marketing problems which are closely related to your work. We are all endeavoring to accomplish the same result-a square deal to the public and satisfied customers. By working together we should be able to accomplish the desired result more quickly and easily than if we work independently.

You have assigned the work of draiting adequate and reasonable specifications and tolerances for measuring devices to your committee on specifications and tolerances. We assume, by reason of the geographic distribution of the members of this committee, that frequent meetings are impracticable. Probably this necessitates the transaction of a greater part of the committee's work at a meeting held just prior to a National Conference. Naturally this produces a feeling of uncertainty in the minds of the members of the institute's committee on marketing equipment, who may be vitally affected by some modification in specifications or tolerances about to be recommended by your committee.

The institute's committee also consists of members having headquarters in various parts of the United States. Its meetings are infrequent, and it is difficult to obtain immediate action on matters relating to specifications and tolerances for measuring devices. 
The situation, however, is not unique in the work of the institute, as we now work cooperatively with a considerable number of organizations which are concerned with some phase of the industry's activities. In some cases the institute is represented in the membership of a committee of another organization. In other cases, joint committees are organized, and where neither of these cooperative measures appear to be practicable, we maintain a small group of specialists which is invited to meet with the committee of another organization.

It is my sincere hope that some mutually satisfactory arrangement may be reached, whereby these two committees can cooperate effectively in the establishment of specifications and tolerances on the measuring devices used in the sale of petroleum products.

The Chariman. Thank you, Mr. Stroop.

\section{SEALED CANS FOR DISPENSING LUBRICATING OIL}

By Martin L. Lang, Commissioner of Weights and Measures, State of Indiana

Manufacturers, distributors, and merchants are constantly searching for new ideas and new marketing methods for their products. Oil marketers have kept pace with the times in this constant search for new ideas and their latest contribution, in this respect, is oil in hermetically sealed cans. Motor oil in sealed cans is certainly not a new idea, as its history can be traced as far back as 1920 .

At that time the quart can was intended only as a reserve supply of motor oil that the motorist could carry with him on long journeys through the country. Automobiles were not developed to the high state of perfection in which we find them today; therefore they required more oil, and, as there were long stretches through the country where no service-station facilities were available, the motorist had to carry a reserve supply with him. Also, many motorists who were particular about the brand and grade of oil used in their motor took this means to protect their motor from an inferior grade of oil.

The canned oil of this period filled the breach in splendid shape, but the increase in the number of highway service stations and the extension of oil companies over large sections of the country lessened the necessity, at that time, for oil in sealed cans. The early promoters of the canned-oil industry recognized the need, but at that time made little progress, probably due to two causes, the comparatively high cost of cans, and no well-developed opener or dispenser.

It is obvious now that this method was bound to fail because of the length of time required to drain a can through the small openings punctured in the top and the inability to get to the fill pipe of the engine without some additional equipment such as a funnel. The sealed cans, at that time, did not prove successful and, although the idea was good, it was temporarily abandoned.

During the dormant period of the sale of canned oil the refineries recognized the good qualities of this method of oil distribution, namely, dirt proof, tamper proof, and the guarantee to the customer receiving full measure of the proper grade of oil; with the result that in 1932 canned oil was reintroduced along with practicable dispensers for draining the oil completely from the can to the fill-pipe of the motor.

It is well to remember that the growth of this new enterprise, the sale of packaged oil, is only in keeping with the growth of all packaged $34678-36-6$ 
goods, such as vegetables, sugar, crackers, dried fruit, etc. The reasons justifying the housewife's preference for packaged food justifies the motorist's preference for canned oil with the additional protection against substitution. The substitution of inferior food would be noticed by the housewife before it reached the table, but the substitution of used or inferior oil might seriously damage a motor before being detected.

The three questions most often raised in discussing, pro and con, the sale of canned oil are, first, the possibility of the used cans being refilled by the oil bootlegger; second, the accuracy of the statement as to grade and SAE (Society of Automotive Engineers) viscosity, as lithographed and embossed on the can; and, third, the correctness of the measure.

In discussing the first question raised-that of the possibility of refilling the used cans-I can best explain this by giving you an explanation of the construction of the cans used. The cans used for this purpose are double seamed, bottom, side, and top. At the extreme top and bottom of the seam found on the side of the can is a notch, or that part of the side wall of the can used when the top and bottom are hermetically sealed on. On close examination of the can you will observe the notch is the end of the double seam which is flattened to a single thickness to permit a perfect union of the side wall to the top and bottom. If the bootlegger cuts off the destroyed cap, the first obstacle he encounters after refilling the can, is to seal the cap over the double seam. This cannot be done successfully due to the thickness of the double seam; leakage would result where the cap and double seam came in contact with each other. In case this oil were to be shipped a leakage would be detected by the person receiving the shipment and he would in turn eye the shipper with suspicion. In addition, the used can would be much shorter, due to the second capping operation, and this would be quite noticeable to the public and to the weights and measures inspector. In resealing these cans the bootlegger would have to obtain a supply of caps or lids on which it would be necessary to have the SAE number embossed. It would be unethical for any can manufacturer to sell or furnish embossed caps or lids without the cans accompanying them and then only to reliable oil refineries, and this practice, I have been reliably informed, is observed by the can manufacturers today.

About the only person who could hope to have any success in the refilling of the cans would be the service-station operator who attempted to augment his supply of correctly canned oil. However, in his case, in addition to the previous handicaps mentioned, the augmenting of his supply would immediately arouse the suspicion of his local distributor who would investigate the decreased sale of his product.

The second question under discussion is whether or not the can contains the oil of a grade and viscosity lithographed and embossed on the can. Every possible precaution is taken by the can manufacturer and the refinery to assure the correct brand, grade, and viscosity of oil asked for by the motorist. The cans are manufactured of a standard size, lithographed, and packed in cases for shipment. The tops or lids of the cans are embossed with the SAE number and this number is also placed on the side of each case of empties. At the refinery the empties are placed on a loading belt which carries 
them to the filling machine, where they are filled automatically. As the cans pass from the filling machine to the automatic capper, the empty cases are being conveyed to the packing machine and by the time the filled cans reach the packer, the empty cases are on hand and ready to be packed and the cases sealed.

Millions of dollars are being spent annually by the oil companies in their laboratory tests to determine the correct viscosity of oil for use in summer and winter in all makes of motors, therefore, it is presumptious for us to believe that our reputable oil refineries would condescend to improperly fill the cans with an inferior grade or a different viscosity than is lithographed and embossed on the can.

The third question-that of correct measure - is one which is always uppermost in the minds of the public and we, as weights and measures officials, are interested in this question raised in connection with sealed oil. It is my opinion that the purchaser of canned oil is as certain of receiving correct measure as he would be by any other recognized method. The cans are manufactured in two standard sizes, namely, the 1 quart, which is used to replenish the supply of oil in the crank case, and the 5 quart, which is used for oil changes. The can manufacturers recognized the fact that oil hermetically sealed would expand at a high temperature; therefore the cans were constructed to contain slightly more than the size stated on the can. They were also aware that weights and measures laws require the delivery of full measure; therefore ample overage was allowed in the construction of the can to take care of "clingage" or the oil adhering to the can after reasonable time has been given for delivery.

The cans are filled at the refinery by automatic-filling machines and these machines are adjusted for packaging oil of different grades and SAE viscosity, to assure full measure. This change is necessary due to the fact that heavier oils have a greater "clingage" than lighter oils. The oil refinery must determine by laboratory tests the amount of clingage for each grade of his respective oil, in each SAE number marketed, and determines by weight the amount of oil sealed in each can in order to dispense full measure, either 1 full quart or 5 full quarts. To further assure the customer receiving full measure filled cans are occasionally taken from the line and reweighed.

It appears to me that the method adopted by the refineries to determine the amount of oil sealed in each can surpasses the method now employed by the service station attendant in measuring in the field, who must rely solely on measurement. The attendant is unable to measure his oil throughout the year at the same degree of temperature, and we all realize a change in temperature will affect, in a small degree, the amount of oil placed in a measure or measured into a container.

I have in the foregoing discussion answered the three questions most likely to be raised relative to canned oil, which are, the possibility of the used cans being refilled by the oil bootlegger; the accuracy of the statement as to the grade and SAE viscosity as lithographed and embossed on the can; and the correctness of the measure. In doing this, I have traced this method of dispensing oil from the manufacture of the cans until it is ready to be dispensed by the service-station attendant. 
We are living today in an era, doubtlessly the most chaotic and bewildering in our entire history. Bootlegging, substitution, tax evasion, and price cutting are rampant on every hand. The reputable and legitimate companies are faced with the unscrupulous practices of a small minority. Because of these practices of a small minority, public suspicion is often directed at an industry as a whole. The retail oil business has come in for its share of adverse criticism, due mostly to conditions over which it has no control and to the unscrupulous practices of a small minority of retail oil merchants.

Formerly, the honest service-station operator, who made a large outlay of capital in barrels of oil of different SAE viscosities, highboys for each oil, etc., had no protection from the operator who sold practically all brands and viscosities out of the same barrel. The unscrupulous operator might without detection dilute a premium oil of a good brand with a competitive oil, and in some instances has been known to dilute premium oil with used oil. Today, with the advent of packaged oil, canned in hermetically sealed cans, the situation has changed. The motorist can take the can of oil in his hands and, without danger of spilling oil on his clothing, read the brand and grade lithographed on the side of the can and the SAE number embossed on the top; he is in a position to assure himself that he is receiving the brand, grade, and viscosity asked for.

Another argument can be used for canned oil, but this is one which does not so materially concern the weights and measures inspector, and that is, freedom from contamination. The sealed can prevents contamination and preserves the original purity of the oil as refined; therefore, the motorist is sure of receiving oil free from dirt, grit, and water.

The sale of the earliest canned oil was handicapped by not having a well-developed dispenser. When sealed oil was first introduced the cans were marked on the top in two places for opening, and this was done at that time with a screw driver or punch; this method of opening the can proved unsuccessful because the small opening made the drainage a slow process. Another drawback was the inability of the motorist to reach the fill pipe of the motor without a funnel.

Much of the success attained by the canned oil of the last few years is attributed to the convenient dispenser. The dispensers in use today are not measures and they have embossed on them the words, "Not to be used as a measure." These dispensers are constructed to open the can in such a way as to destroy the can for future use and to permit rapid and complete drainage. The dispensers have therefore helped to make possible the rapid progress made by the oil industries in the sale of canned oil.

The dispensing of oil in hermetically sealed cans has met the general approval of the service-station attendant and the buying public as well. The interests of both, as well as the interests of the refinery, are guarded to the greatest possible extent. Therefore, it is my opinion that this Conference of weights and measures officials should at this time approve of the sale of oil in cans and adopt whatever specifications, regulations, or tolerances relative to both cans and dispensers as may be deemed necessary to safeguard the buying public in respect to correct measure, correct grade, and correct viscosity of the oil bargained for and paid for. 
A few words in closing. We are trying to step forward, not backward. The matters presented in this paper are for the committee on specifications and tolerances to look into. I want to thank those who furnished the dispensing cans and this fine display of various types of openers.

Again I want to express my feelings for the fine cooperation given me in the past $2 \frac{1}{2}$ years by the National Bureau of Standards.

The Chairman. Thank you, Mr. Lang.

\section{DISCUSSION OF AEOVE PAPER}

Mr. Crocketr. Mr. Lang, you spoke about the leakage that would occur in the shipping of oil in cans that had been refilled. What percentage of leakage would you expect, if the cans had been tampered with?

Mr. LANG. This paper was prepared after a survey made in the State of Indiana, and possibly over 12 other States, Nebraska, Iowa, Kansas, Missouri, and some of the Eastern States. We think there is a very small percentage of tampering.

Mr. Crocketr. The main trouble that you have is not with the refinery?

Mr. LANG. We are not troubled by the refinery.

Mr. Crocketr. Would you say there might be trouble with the station operator? Could not the station operator refill a can?

Mr. LANG. It has been done.

Mr. Crocketr. I will show you a few samples of refilled cans, the operation being performed with a tool that only costs 20 cents. Here are some cans which I refilled myself. The first one I refilled took me about 35 minutes. I could do it now in 45 seconds. (Exhibits cans.) We try to make them destroy the cans. You just can't do it. It is very easy for anyone around a service station to refill the empty cans with crankcase oil and make a 25 -cent profit on it. I have shown some of these refilled cans to various people and the only ones who could find that they had been tampered with were the mechanics in the shops. How many motorists take one of these cans in the hand to look at it? How many weights and measures men do?

Now these cans, with the exception of one, have all been soldered. Here you see one with just a slight spot of oil on the outside. That is not soldered. I will show you how it is done. (Demonstrates taking top off can with knife.) There you are. If the can had been soldered I could still do it in less than a minute. To do away with this you should make them destroy the lid or side of the can as it is opened.

Mr. Richards. It seems strange to us, as glass manufacturers, Mr. Lang, that in the paper you prepared no mention was made of the glass container for dispensing lubricating oil.

Mr. LANG. I am not condemning glass. Lubricating-oil bottles have been approved. This subject was sealed cans; hence I stuck to the subject.

Mr. VANDERsLice. There are on exhibit in connection with this paper, various types of openers. In Philadelphia, I don't think we have accepted any opener, except one that rips the can up the side.

Mr. R. E. Meek. I wish to call attention to the fact that Mr. Lang referred those questions to the Committee on Specifications and Tolerances. These questions can be answered correctly only after 
careful study. They should be handled by that committee. We could go on for days discussing this matter.

Mr. LANG. This is a hot subject. I knew that before I left Indiana. I feel that it should be left to the Committee on Specifications and Tolerances.

Mr. ЈАКов (representing the Continental Can Co.). Mr. Chairman, what this gentleman showed here was something I saw about a year ago. There was some mechanic that worked out of Baltimore who had some spare time, so he made six samples and sent them to us. There are probably all kinds of ideas as to things that can be done, but, after all, it isn't really a fact that they actually happen in practice.

We have heard rumors from time to time about substitutions. We have spent thousands of dollars trying to trace them down. There is only one case I know of that actually happened. That was in Dayton, Ohio, and that man was caught. He wasn't caught by anybody that saw him make the refill. The only way he was discovered was by the fact that the oil company from their records discovered that whereas he had formerly bought 300 cases a month, he was eventually only buying 30 . I really think that this idea of refilling a can is just a bugaboo that hasn't materialized, except in this one case.

We have tried our best, doing so to help the refinery and to protect our own business. All service stations are being watched as to amounts purchased and sold.

The Charrman. Gentlemen, I think, perhaps we have discussed this long enough. We haven't much time, and the particular aspect under discussion is not a weights and measures problem.

REPORT OF COMMITTEE ON SPECIFICATIONS AND TOLERANCES ON MODIFICATION OF CODE FOR VEHICLE TANKS, PRESENTED BY F. S. HOLBROOK, CHAIRMAN

Mr. Chairman and gentlemen, your Committee on Specifications and 'Tolerances has prepared its report on modifications deemed advisable in the code of specifications and tolerances for vehicle tanks. This has been available for some time and doubtless each of you has a copy at hand.

One of the principal changes recommended in this code consists in recognizing for the first time vehicle tanks equipped with meters. As you will remember, the code at present in effect deals only with vehicle tanks when used as measures. Consequently, the definition has been changed to some extent, and the code has been split into three parts. The first part consists of general specifications, which are equally applicable both to vehicle tanks used as measures, and to tanks equipped with meters; the second part contains those specifications which are applicable only to tanks which are used as measures; and the third part refers solely to tanks on which meters are mounted.

Notes.- "General Specifications" shall apoly to vehicle tanks either used as measures or equipped with meters. "Specifications for Vehicle Tanks Used as Measures" shall apply to vehicle tanks when the tanks or the compartments thereof are used or to be used as measures to determine the amount of liquid delivered. "Specifications for Vehicle Tanks Equipped with Meters" shall apply to vehicle tanks on which meters are installed to determine the amount of liquid delivered.

In determining the capacity of a vehicle-tank compartment, water is recommended as the testing medium. In testing the accuracy of a vehicle-tank meter, 
the testing medium should be liquid of the same character, or of approximately the same viscosity, as that of the liquid to be commercially measured. Whenever the testing medium is a petroleum product, due care should be exercised to redude to a minimum, inaccuracies caused by evaporation or by volume change resulting from change of temperature of the liquid.

In reading the above I have added the additional words "or of approximately the same viscosity" after the word "character" in the clause "should be liquid of the same character as that of the liquid to be commercially measured". These added words are not on the copies in your hands.

The committee recommends the words which I have orally inserted to make it unnecessary for the weights and measures official to use hazardous testing means in his calibration of the tanks. We all know that liquids are available which will behave in a manner similar to gasoline, for instance, but which are not equally inflammable and explosive.

A vehicle tank is an assembly used for the delivery of liquids, comprising a tank, which may or may not be subdivided into two or more compartments, mounted upon a wagon, automobile truck, or trailer, together with its accessory piping, valves, meters, etc. The term "compartment" shall be construed to mean the entire tank whenever this is not subdivided; otherwise it shall mean any one of those subdivided portions of the tank which is designed to hold liquid.

\section{GENERAL SPECIFICATIONS}

1. Permanence.-A vehicle tank shall be so designed and shall be of sufficiently substantial construction that it may reasonably be expected to withstand ordinary usage without impairment of the accuracy of the deliveries made therefrom; the shell and the bulkheads shall be of such construction that they will not become distorted under any condition of liquid lading.

2. Venting Means.-Each compartment shall be provided with suitable venting means to prevent the formation of air pockets by permitting the escape of air from all parts of the compartment designed to be filled with liquid and to permit the influx of air to the compartment during the process of delivery.

3. Marking.-All lettering and figures required under these specifications shall be of such size, design, material, and location, and shall be so applied or affixed, that they will not tend easily to become obliterated or illegible.

4. Fraudulent Construction.-All vehicle tanks and all devices designed to be attached thereto and used in connection therewith shall be of such design and construction that they do not facilitate the perpetration of fraud.

\section{SPECIFICATIONS FOR VEHICLE TANKS USED AS MEASURES}

5. Indicators.-An inaicator shall be provided within the fill opening of each compartment, which shall be located approximately midway between the ends of the compartment. The indicator shall be so designed that it will cuearly, distinctly, and unmistakably define the height to which the compartment must be filled in order to contain its marked capacity. If this indicator is adjustable it shall be so constructed that it can be sealed in such a manner that its position cannot be changed without destroying or mutilating the seal.

6. Expansion Space.-The indicaior shall be so positioned that when a compartment is filled to the indicator there will remain an expansion space of not less than 0.75 percent of the nominal capacity of the compartment.

7. Provision for Complete Delivery.-The tank and the delivery piping shall be so designed and constructed and shall be so mounted upon the vehicle that when this is standing upon a level surface complete delivery may be made from any compartment through the delivery faucets or valves whether other compartments are full or empty.

8. Diversion from Manifold.-When two or more compartments discharge through a manifold, effective and automatic means shall be provided to prevent the passage of liquid from the manifold into the discharge line from any compartment. 
In relation to the specification last read, it may be said that it has been found that if the lines to the manifold from one or more empty compartments are open when discharging from one compartment, the liquid will back up into such compartments and level off in these compartments. That furnishes an opportunity for fraud because after the above operation has taken place it would be possible for the man delivering the load, to close the manually-operated valves in the lines from these compartments in which the liquid has leveled off and thus trap the liquid which has entered these compartments.

9. Piping.-When emergency valves designed to close the discharge outlets from compartments are provided, the capacities of such compartments shall be construed as including the capacity of the piping leading therefrom, and such emergency valves shall always be open when compartments are being filled or their capacities are being checked.

10. Marking of Capacity.--Each compartment of a tank shall be plainly and conspicuously marked with a designating letter or figure and each delivery faucet or valve shall be correspondingly marked to indicate the compartment of which it is the outlet. In addition, the tank shall be plainly and conspicuously marked to show the caparity, to the nearest half gallon, of each compartment and such marking shall indicate that the capacities given are measured to the indicators provided. This latter marking shall be placed adjacent to the faucels or valves.

\section{SPECIFICATIONS FOR VEHICLE TANKS EQUIPPED WITH METERS}

11. Meter Requirements.-Meters installed on vehicle tanks shall conform to all applicable requirements of the snecifications for liquid-measuring devices of the wholesale type, except insofar as these may be modified by the following requirements.

12. Return of Indicating Element to Zero.-Meters installed on vehicle tanks shall be so designed and constructed that the indicating element used to tally sales and deliveries to individual purchasers or to indicate the amount delivered when any portion of the cycle or stroke has been completed shall be returnable readily to a definite and clear zero indication before the next delivery is begun. Means shall be provided to prevent the indicating element from being returned beyond the zero graduation. The indicating element may be advanced only by the mechanical operation of the device itself: Provided, however, That the device may be cleared by advancing the indicating element, but in this event the indication shall be obscured and remain obscured, until the zero is reached.

13. Location of Meter.- The meter shall be so positioned that the indications may be easily and accurately read.

14. Discharge Lines. - If the unit be designed for discharge by gravity, the discharge line shall be as short as practicable and there shall be no shut-off valve at its discharge end. If the unit be designed for discharge by means of a pump, the discharge line shall be of the wet-hose type with a shut-off valve at its discharge end, and immediately adjacent to this discharge valve there shall be installed a spring-loaded check valve so adjusted that drainage of the discharge line will automatically be prevented.

15. Diversion of Measured Liquid.-No means shall be provided by which any measured liquid can be diverted from the measuring chamber of the meter or the discharge line therefrom.

16. Air Elimination.-Adequate provision shall be made for preventing the passage of air through the meter. In a gravity-discharge unit, if a mechanical air eliminator or other means, to prevent inaccuracies of measure due to air or vapor in the liquid, be not provided, provision shall be made for preventing a vortex at the point of discharge from the compartment whereby air might be drawn into the line leading to the meter, and the meter shall be so mounted and the piping so arranged that the meter will not be drained of liquid during normal operation and that air will not be trapped in the meter inlet line when a compartment is filled. In a pump-discharge unit, a mechanical air eliminator or other means shall be provided adjacent to the meter inlet. This air eliminator or other means shall be considered effective if the provisions of specification 17 are complied with.

17. Constancy of Delivery.-The amounts delivered shall not vary from the standard by more than the tolerances hereinafter provided, (1) during continuous or intermittent discharge of liquid; (2) at all speeds of pump operation; and (3) 
when the meter is operated at the maximum rate permitted by the installation, when operated at the rate represented or believed to be normal for the installation, and when operated at a rate approximately one-half the normal rate, or at a rate of approximately 20 gallons per minute, whichever is less.

Nоте. - Meters installed on vehicle tanks should be tested at each of the three discharge rates specified. The minimum testing draft shall be 50 gallons.

\section{TOLERANCES}

Vehicle Tanks Used as Measures.-The tolerances to be allowed in excess or deficiency on all vehicle tank compartments which are being tested by the weights and measures official for the first time, to verify the accuracy of a capacity marked by a manufacturer or user, shall be the values shown in the column headed "On first test" in the following table. The tolerances to be allowed in excess or deficiency on all subsequent tests made by the official, to verify the accuracy of a marked capacity, shall be the values shown in the column headed "On subsequent test." These tolerances are to be applied to the difference between the actual result of the calibration and the marked capacity of the compartment. Whenever the result of a calibration indicates that the marked capacity of a compartment is not correct within the tolerance to be applied, if the capacity of the compartment is adjustable, then the marking shall be changed in accordance with the provisions of specification 10 , or the result of the calibration shall be taken as the basis of an adjustment and the adjustment shall be so made that the capacity of the compartment agrees as nearly as may be with such marked capacity; if the capacity of the compartment cannot be adjusted to agree with the marked capacity, then the marking shall be changed in accordance with the provisions of specification 10 .

\begin{tabular}{|c|c|c|c|}
\hline \multicolumn{2}{|c|}{ Capacity of compartment } & \multicolumn{2}{|c|}{ Tolerances } \\
\hline From- & $\begin{array}{l}\text { Up to and in- } \\
\text { cluding - }\end{array}$ & On first test & $\begin{array}{l}\text { On subse- } \\
\text { quent test }\end{array}$ \\
\hline $\begin{array}{c}\text { Gallons } \\
-\overline{175} \\
325 \\
475 \\
575 \\
725 \\
875 \\
975 \\
1,125 \\
1,325\end{array}$ & $\begin{array}{c}\text { Gallons } \\
175 \\
325 \\
475 \\
.575 \\
725 \\
875 \\
975 \\
1,125 \\
1,325 \\
1,500\end{array}$ & $\begin{array}{c}\text { Gallons } \\
1 / 2 \\
1 / 2 \\
3 / 2 \\
1^{3 / 4} \\
11 / 4 \\
11 / 2 \\
13 / 4 \\
2 \\
21 / 2 \\
3\end{array}$ & $\begin{array}{c}\text { Gallons } \\
1^{1 / 2} \\
1^{1 / 2} \\
2^{1 / 2} \\
2^{1 / 2} \\
3^{1 / 1} \\
4^{1 / 2} \\
5 \\
6\end{array}$ \\
\hline
\end{tabular}

Vehicle Tanks Equipped with Meters.-The tolerances to be allowed in excess or deficiency on meters installed on vehicle tanks shall be the same as those specified for liquid-measuring devices of the wholesale type, that is, 1 cubic inch per indicated gallon of delivery with a minimum tolerance of 50 cubic inches, for meters in use, and one-half of these values for new or reconditioned meters.

\section{REGULATIONS}

1. If a vehicle tank be damaged, repaired, or modified in any way which might affect the accuracy of measurement of its deliveries, it shall not again be used for measurement until inspected and, if deemed necessary, tested, by the weights and measures official.

(Signed)

F. S. HoLbrook, Chairman, JosEPH G. ROGERS, John P. McBride, Geo. F. Austin, Jr., 
The Chairman. The matter is now open for discussion. We will consider specification 1 .

(The specification as proposed by the committee was duly adopted.)

Mr. Holbrook. I would like to say that specifications 2, 3, 4, 5, 6 , and 7 are unchanged in text. Specifications 2, 3, and 4 have been made generally applicable to all vehicle tanks within the purview of this code, while 5, 6, and 7 are suggested for application only to vehicle tanks used as measures.

Mr. Griffith. I move you, Mr. Chairman, that all of the specifications which Mr. Holbrook has mentioned, be adopted as submitted.

(The motion was seconded.)

Mr. Baucom. Mr. Chairman, in reference to specification 6, I understand that the railroads have for years recommended and required 2-percent expansion space in their railroad tank cars. Of course the figure given here is less than that amount. We find that 25 States have adopted the railroad figure. We find that threequarters of 1 percent is not sufficient expansion space, and have changed it in my State so as to allow a sufficient amount for safety. I was just wondering whether we should increase the figure suggested here. It wouldn't cause any difficulty to any vehicle tank in use. I have made all put in indicators so positioned as to provide for expansion.

Mr. Stroop. On the question raised by Mr. Baucom, it is true that railroads under the Interstate Commerce Commission regulations require a 2-percent expansion. However, the Interstate Commerce Commission in their truck regulations require an expansion space of only three-quarters of 1 percent.

Mr. BAUCOM. I am satisfied.

Mr. Bundenthal. Mr. Chairman, I notice that specifications 5 and 6 are recommended to be nonretroactive.

Mr. Holbrook. They are nonretroactive in the present code.

Mr. Bundenthal. I can see no reason why specifications 5 and 6 should be nonretroactive now. I would like to ask Mr. Holbrook's reason therefor. They may have a good reason for doing that.

Mr. Griffith. The reason it is done is that it so appeared in the former issue of the specifications. However, specifications 5 and 6 are such that they have already been complied with by vehicle-tank manufacturers. I am confident that in the majority of jurisdictions tanks generally comply with these two specifications.

Mr. Bundenthal. I move to amend the motion to make these two sections retroactive.

Mr. Holbrook. I think there would be no objection on the part of the committee. This code has now been in effect since 1925 . Doubtless vehicle tanks now in use comply with these requirements.

The Chairman. The motion now is that specifications $2,3,4$, and 7 be adopted as recommended by the committee, and that specifications 5 and 6 be adopted as recommended, except that they be made retroactive.

(The question was taken, and the motion was agreed to.)

Mr. Grifrith. Mr. Chairman, I move you the adoption of specification 8 as recommended by the committee. 
(The motion was seconded, the question was taken, and the motion was agreed to.)

Mr. Griffith. I am going to move you, Mr. Chairman, that specification 9 be amended to the effect that the capacity of the compartments shall not include the piping outlets. The reason for that is the experience recorded in our office extending over a long period of time.

In actual practice in checking vehicle tanks on the street, we found that while the pipes were filled at the loading rack, before the control valves were closed, enroute between the loading rack and the delivery point, the pipes would be emptied. There would be no indication, as to how it happened, but we arrived at the conclusion that it had happened, since when the control valves at the bottom of the compartment were opened the liquid flowed into the outlet pipes at the time of delivery, and the delivery was short measure. We consider that these pipe outlets are not part of the capacity of the tank vehicle, and should not be included in the calibration. I therefore move you that section 9 be changed so as to eliminate the pipe outlets from the calibration and that only the capacity of the compartment be included.

Mr. Ragland. I will second that motion. You say that it is in our present code, but the words "emergency valves" are used; these pertain to fire hazard. The words should be "control valves."

Mr. Davis. Before this motion is considered I want to say I oppose the amendment offered by the gentleman from Baltimore, and hope it will not prevail for this reason: In Vermont we are continually having trouble with tank wagons that are being sent in, principally from Massachusetts, that have been calibrated in Massachusetts with the valves closed. We have been working under this specification as it now stands in the code. When our man goes around to calibrate the compartments, he opens the valves and calibrates them in that manner.

(At this point, at 1:02 p. m., the Conference took a recess until $2 \mathrm{p} . \mathrm{m}$.) 


\section{SIXTH SESSION-AFTERNOON OF THURSDAY, JUNE 6, 1935}

(The Conference reassembled at 2:14 p. m., at the National Bureau of Standards, Mr. John P. McBride, presiding ofiicer, in the chair.)

\section{DISCUSSION OF REPORT OF COMMITTEE ON SPECIFICATIONS AND TOLERANCES ON MODIFICATION OF CODE FOR VEHICLE TANKS-Continued}

The Chairman. Gentlemen, we are on specification 9 for vehicle tanks.

Mr. White. I make a motion that specification 9 be amended to read as follows:

Vehicle tanks shall be equipped with control valves designed to close discharge outlets from compartments provided, and the capacities of such compartments shall not be construed to include the capasities of the piping leading therefrom, and such control valves shall always be closed when compartments are being filled, or their capasities are being checked.

(The motion was seconded.)

Mr. O'Kenene. Mr. Chairman, the piping is part of the tank, and should be included in the capacity of the tank.

Mr. RaGLAND. Our practice in the city of Richmond for 3 years has been in accordance with the amended wording proposed. I think some of us have not studied this as carefully as we should. My good friend, O'Keefe, as evidenced from his remarks, hasn't looked into it. I want to say I have in my hand here a catalog of one of the largest vehicle tank builders in America. As evidenced by this catalog, many of the largest oil companies are using these trucks. Their practice is to exclude the piping.

Now, on the point that Mr. O'Keefe expressed. Your present specification reads as follows. [Reads specification 9 as proposed by committee.] Who is going to be there to see whether the valves are open or not when the filling takes place? The very minute that truck driver goes beyond a certain point he can close the valves and open the lines. Mr. Holbrook said there was a splendid opportunity for fraud when open lines to empty compartments led into a manifold. The identical opportunity exists here. Dr. Dickinson in his talk today dwelt on this very thing, stating that the fire underwriters recommended that the piping be closed. Furthermore, a certain State does not allow tank wagons to go on its highways unless the truck is equipped with valves to prevent the gas going into the lines.

Here is a city where it is provided that no automobile tank truck, or trailer on same, shall be registered for the year 1932, or thereafter, nor shall any such vehicle be operated on the public highways subsequent to its registration, unless it is in compliance with the following minimum specification. Now see what the minimum specifications are:

Every compartment of a gravity discharge tank shall be provided and equipped with a sufficient shut-off valve located in the compartment outlet, except it be 
located in the shell of the tank compartment, and except during the delivery operation, such valve shall be automatically kept closed.

In other cities and in the New England States, I find they have similar requirements.

Gentlemen, why should not a compartment be equipped with a shutoff valve? Then the line can be left empty. When a man gets up on top of the truck to look at the indicator, he can see whether the valve is closed. When this specification was formerly adopted, you were accustomed to find a great deal of leakage in these valves. The present-day valves are positively leakproof. We checked a vehicle tank that drove 6 miles over rough streets; when it arrived at the point of unloading, the gas was just breaking away from the indicator. I opened the valve and out of the pipe line I didn't get a pint.

The company I mentioned a short time ago- the largest I know of will guarantee you an emergency valve-control mechanism; their tanks are equipped with this valve. I want to tell you that I am just as much interested in the manufacturer as $I$ am in the customer.

All you sealers know there is a lot of difference between a man behind a desk and the man who sells his wares. There is a lot of difference in sitting there and in going out in the field and seeing action. I am not a technical man, but as a man working in the field I do know a little about this subject. If there is any chance of perpetrating fraud with a manifold of the type described, there is the same chance presented in the construction required by this specification.

Mr. O'KEEFE. If there isn't anything very serious about it, and there is no chance of fraud, why not leave those provisions in there, and let the fellow making the tests find it out; that is, if you follow out your specifications.

Mr. Griffith. Might I say to Mr. O'Keefe, that if the pipes are part of the measured capacity, there is a chance of fraud. They close off the pipe, then drain the piping, and you find that much is gone.

But if you calibrate with the valve closed and the pipe empty, you check that.

Mr. Holbrook. The first requirement of the amendment proposed by the motion, is that all tanks be equipped with control valves. The evidence before the committee is, that while the control valve is very common in the east, it is very rarely used in the west; the estimate was made that only twenty to twenty-five percent of the vehicle tanks throughout the country are equipped with control or emergency valves at the present time. I think this first portion is not a proper weights and measures regulation. As I understand it, the control valves or emergency valves are for safety purposes solely. Therefore, it seems to me, if this Conference goes on record as requiring control or emergency valves it will be passing a safety regulation rather than a weights and measures provision.

Now as to whether piping should be full or empty. The committee spent a lot of time on that, and perhaps the factor which governed the committee in its decision that the specification should remain unchanged was the partial compartment delivery.

When a partial compartment is sold, the determination of delivery is very frequently made with a gage stick. When the compartment has been calibrated with the delivery pipe empty there is no ready means to correct for the variance caused by the filling of the piping; 
that is, we have this condition existing. [Draws diagram on blackboard. See fig. 7.]

Now you start with the compartment filled to this point [indicating "indicator"], and this valve [indicating "emergency or control valve"] closed, and this pipe [indicating "delivery piping"'] empty of liquid. When you open the emergency valve, as I designate it, or the control valve, as some of you prefer to call it, the liquid drops down to a point somewhat below the indicator and the delivery piping fills with liquid. Then you open the delivery valve located at the rear of the truck [indicating] and a certain amount of liquid flows into the underground tank of the service station, and the level of the liquid in the compartment falls to some point such as this [indicating

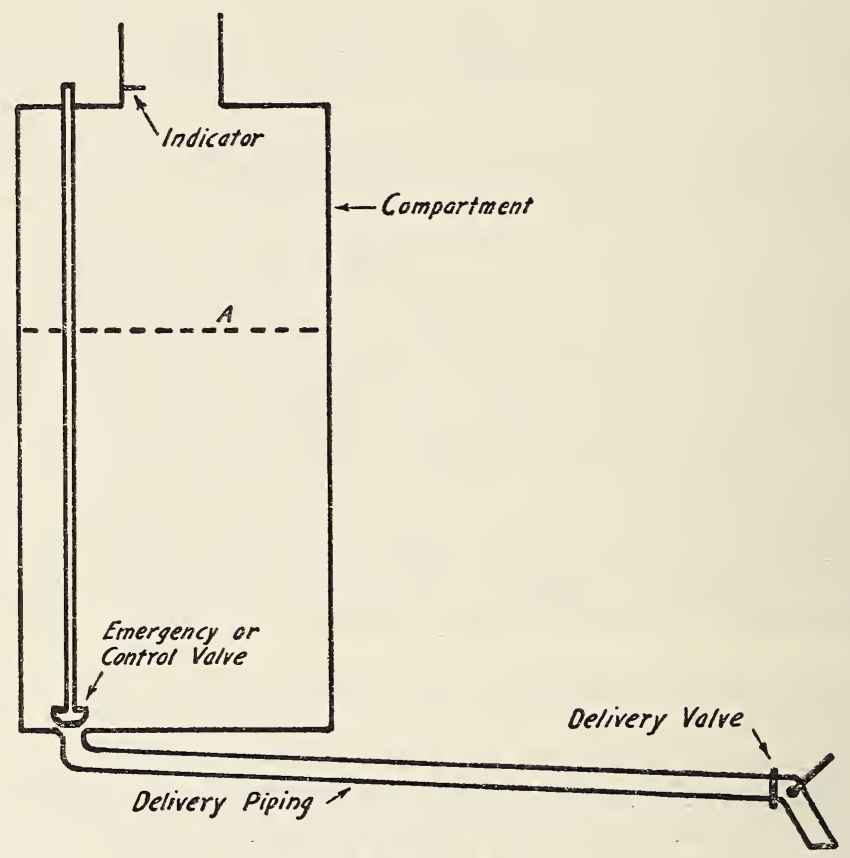

Figure 7.

dotted line "A"]. Now you close the delivery valve and "stick" the compartment to find the amount of gasoline supposedly delivered. What you do in effect is to measure the capacity contained between those two points, the indicator and the subsequent level of the liquid; in other words, the liquid which has flowed out of the compartment. But this delivery piping is now full, and it was empty at the start. So included in the measurement is the amount now remaining in the piping. The first purchaser inevitably loses the amount of liquid contained between the emergency valve, and the delivery valve on the back of the truck.

Mr. RAGLAND. If the absence of a control valve facilitates the perpetration of a fraud, it is a weights and measures problem.

Mr. Holbrook. As outlined, it is not a weights and measures issue, gentlemen, I submit. 
Mr. Griffith. If one purchaser gets less than he is entitled to, it is obvious that some other person gets more. Now, does the committee proposal prevent that discrepancy?

Mr. HoLBRook. Yes; if you start off with the delivery piping full, then this line is full at the beginning and the end of a partial delivery. The gage stick is calibrated on this basis. It then measures the amount of liquid delivered each customer.

Mr. Griffith. You already said one customer gets more and the other less.

Mr. Holввоок. The first customer gets short measure. If the remainder of the liquid in the compartment is eventually delivered on that same trip and the compartment and line emptied, then the last customer gets over measure. If they carry that compartment back partially full, then the amount in the line is retrieved.

Mr. GRIfFith. That is a polite word, "retrieved". I agree with you when you say that some of the tank vehicles are not equipped with control valves. Therefore I have rewritten this specification 9 in a few words, which I think will cover that point, and with the permission of Mr. White, I would like to substitute this wording:

Specification 9. Piping.-Vehicle tanks equipped with control or emergency valves, shall have such valves at the lowest point of outlet from each compartment, and the capacities of such compartments shall be construed as not including the capacity of the piping leading therefrom.

Mr. Holbrook. I think those first words very necessary, since emergency valves are not made mandatory. However, you still have not met the problem of short measure to the first purchaser of a partial compartment, when a gage stick is used for finding the amount of the delivery. A portion of his delivery will be trapped in the delivery line.

Mr. Engelhard. You certainly will not open the control valve until you are ready; when it is closed, what remains is evidenced by the stick. You have an exact amount there, the quantity measure.

Mr. Dice. Anybody knows that the number of times the measuring stick is used to determine partial compartment deliveries is very small. In the first place, liquids of dissimilar gravities will not fill the lines to the same point, and on the first opening of the emergency valve between a full compartment and an empty line it is likely that more or less air would be compressed and that a greater or lesser amount of liquid would enter the pipe. In the second place, the piping is not put in as part of the capacity of the measuring unit. In the third place, just because reliable tank manufactures do or do not include the piping in their measurements, is no reason why this association should follow their practice.

I believe that in the State of New Jersey emergency valves are looked upon as a fire-hazard proposition. They are safety valves. I believe that the compartment alone should be used as the unit of measure, and that a vehicle tank should be so calibrated.

To get a proper filling of the drain line, you must first open the drain valve so that the air is all eliminated from the line, and then refill the compartment up to the mark; then you calibrate to the outlet valve. Vehicle tanks are not so used in practice. The filling is done with a closed emergency valve. Even with the emergency valve open, some air would be compressed in the line and the compartment and line would not be properly filled. I don't see that the pipe should have anything to do with the capacity. 
Mr. Beebe. Is the use of a measuring stick for the sale of liquid an approved method?

The Chairman. No; I think not.

Mr. BeEBe. Why consider it at all?

Mr. Holbrook. Because this Conference should face the facts and recognize that measuring sticks are actually used, in sales of partial compartments.

Mr. BEEBE. It is illegal.

The Chairman. I don't think it is, in some places. I imagine that in a very large number of jurisdictions it is not illegal at all.

Mr. Griffith. It is unreliable and not approved.

Mr. RaGland. Do you know of any oil company that would approve a gage stick; that would use it on one of their trucks and accept the result? If you are going to allow people to use an approximate measure, then we are in trouble.

Mr. Holbrook. The question is how one is going to sell a partial compartment, under the construction contemplated in the amendment, without short measure resulting. In these times it is very probable, indeed, that partial compartments will be sold to service stations, many of which have no crealit but are allowed to buy only for spot cash. In very many cases, unfortunately, their cash is not sufficient to enable purchase of a full load.

Mr. White. I disagree with the opinion of Mr. Holbrook as to whether we have a right to require the installation of these so-called "control valves." I believe we have a right to consider anything of this kind when we consider it would prevent fraud.

Mr. Holbrook. I do not see how the installation of a control valve prevents fraud.

Mr. BAUcom. Gentlemen, some city ordinances have been passed making it mandatory that all kinds of safety devices be on a tank wagon. Other jurisdictions do not have such ordinances. In requiring that tanks be equipped with safety valves or control valves, you must remember we are setting up a regulation to cover tank wagons in all territories.

Mr. Griffith [interposing]. The proposal applies only when they are so equipped.

Mr. BAUCOM. I recognize that point. The majority of tank wagons within the United States are not so equipped. Your action will be used as a sales talk for selling these devices to be put on wagons. In my State we have about 200 of these bulk tanks, and if we are called upon to calibrate and certify the quantity of the tank, we must start at a definite point. There is often something faulty with these valves. They will not work. Purchasers of gasoline in quantities may even cause those valves to leak, so as to get that much more gasoline.

We should accept the specification as the committee recommended.

Mr. DicE. I believe that it is our job to inspect or test instruments as we find them, so we test tank wagons as we find them. I for one don't propose to be a party to recommending certain devices to gasoline companies and to manufacturers. That is something that does not come under the head of weights and measures administration.

I assume that these gentlemen that are on this committee are not novices, and it is evident that they studied this thing thoroughly. I am perfectly willing to accept their thoughts on the matter and I 
think the body, as a whole, should do so. They gave it their time and attention and brought out what they thought was best for all concerned.

The Chairman. Gentlemen, as the matter now stands, Mr. Griffith's motion is in order, since Mr. White agrees to pass his motion.

(The question was taken by yea-and-nay rote, and the issue was in doubt. Thereupon a rising vote was taken, and, upon the count showing 32 in favor of the motion and 28 opposed, the motion was agreed to.)

(At this point motions were made and seconded to adopt specifications 10 and 11 , as proposed by the committee. The questions were taken, and the motions were agreed to.)

Mr. HolвRоoк. In relation to specification 12 I may say this has been amplified, because it has been pointed out that the language at present in effect permits the return of the indicator to zero in either direction; in other words, it seems that the indicator might be advanced by manual means thereby making it possible to increase the indication of the amount delivered to the purchaser.

Mr. Badcom. I think compliance with the proposed requirement is practically impossible. My friends might not agree. The manufacturer will have to put some sort of a shield over the face in order to turn it back to zero.

Mr. HoLBROoK. That is only in case the return is to be made in a forward direction. You have to obscure the indication only when you advance the indicating element by manual means.

(The specification as proposed by the committee was duly adopted.)

(The same action was taken in relation to specifications 13 to 17, inclusive.)

Mr. Bundenthal. Aithough we have passed section 14, in view of the discussion on section 9, I cannot refrain from suggesting that under the provisions of section 14 , there is a good possibility of fraud. We are providing for the use of wet hose which may be perhaps, 50 feet long. If you start with the hose empty, and when you finish have it full, that might be another way of "retrieving" an amount of liquid, in this case equal to the capacity of the hose.

Mr. HoLBROоK. The specification provides for a spring-loaded check valve at the end of the hose, so that the hose cannot be drained.

Mr. Bundenthal. When you fill your tank there is no liquid in the hose.

Mr. Dice. When the tank is emptied the hose and meter would be left full.

Mr. Griffith. Specification 14 applies to tank trucks equipped with meters, whereas specification 9 refers to tanks without meters; that is, those which are used as measures.

Mr. Bundenthal. If you start with an empty tank, of course, your hose is also empty; then your hose fills up, the meter records the amount which goes into the hose, but the amount in the hose is not delivered.

Mr. Grifrith. You cannot drain the hose on account of the valve at the end.

The Chairman. Does the Conference desire to go back to specification 14? If so, a motion to that effect is in order. Otherwise we will keep going forward.

34678-36-7 
Mr. Griffith. Let us go forward, Mr. Chairman.

(Mr. Holbrook reread the material under the heading "Tolerances.")

Mr. Griffith. The tolerances as specified only go up to 1,500 gallons. We are now confronted with calibrating trucks with capacities up to 4,000 gallons. Did the committee give any consideration as to tolerances to be allowed beyond 1,500 gallons? The tolerances given in the table, as I see it, could be extended indefinitely.

Mr. Holbrook. Yes; the table could be continued, if you like. We could lay out several tolerance values for greater capacities on the same scale.

Mr. Griffith. Let us include say, 2, 3, and 4 thousand gallons. I move you the adoption of the tolerances as recommended by the committee.

(The motion was seconded, the question was taken, and the motion was agreed to. The same action was taken in relation to the material under the heading "Regulations.")

\section{ANNOUNCEMENTS}

The Chairman. The secretary has an announcement to make.

Mr. Holbrook. An unfortunate mistake was made in printing the program of the Conference. The Executive Committee as printed in this program is the Executive Committee of the Conference held in 1930, not of the last Conference, held in 1931. In other words, the names of several who are on the present Executive Committee this year, are not recognized as being on the Executive Committee by this program. To correct these omissions, we have had a correct list of the members of the Executive Committee printed and have pasted this on some of the copies of the program. Anyone desiring a copy of the corrected program may obtain one at the secretary's table.

\section{DEMONSTRATIONS OF RECENT DEVELOPMENTS IN LIQUID. MEASURING DEVICES, BY REPRESENTATIVES OF MANUFAC- TURERS}

Secretairy's Note.--At this point several manufacturers brought before the Conference samples of liquid-measuring devices and attachments embodying new design features, and demonstrated them to those in attendance. Particular attention was given to the new features incorporated, the method of manipulation of the adjustments provided, and the answering of questions asked by members. As was the experience in former cases, it was found that, in general, the remarks made are of no value to a reader when a sample of the product is not before him, and thus no good purpose would be subserved in printing such material here. Consequently it has been decided to omit this material from the report.

It may be noted that such demonstrations as these, which familiarize the delegates with new apparatus, are of great interest and value to them. Attendance at the Conference is the only way in which full advantage can be obtained from program features such as this. The delegates were duly appreciative of the efforts of the manufacturers who took part in this demonstration.

\section{REPORT OF COMMITTEE ON SPECIFICATIONS AND TOLERANCES ON MODIFICATION OF CODE FOR LIQUID-MEASURING DEVICES, PRESENTED BY F. S. HOLBROOK, CHAIRMAN}

Mr. Chairman and gentlemen, you have in your hands the report of the committee, containing recommendations for amendments proposed in the code for specifications, tolerances, and regulations for liquid-measuring devices. That report contains all the specifications 
which are recommended to be modified by the committee, presented in their amended form.

Formerly, our liquid-measuring device code has been applicable only to retail devices. Now it is recommended that it include requirements for both retail and wholesale devices. Consequently the definition has been appropriately modified.

In general, the first specifications to be encountered will be recognized as those applicable both to retail and to wholesale devices. There will then be submitted specifications referring to retail devices only. Finally there will be presented for consideration specifications referring to wholesale devices only.

\author{
(Signed) F. S. HoLBrook, Chairman, \\ JoSEPH G. ROGERS, \\ JoHN P. McBride, \\ Geo. F. Austin, Jr.,
} Committee on Specifications and Tolerances.

\title{
DISCUSSION OF ABOVE REPORT
}

Mr. Holbrook. Mr. Chairman, I feel that we will save time if we consider these paragraphs as we go through them, thus rendering it unnecessary to read the code twice.

The first specification recommended for amendment is 4, "Units of Delivery." It is proposed to amend this to read as follows:

4. Units of Delivery.-Liquid-measuring devices shall have the following discharge capacities per stroke or per cycle of the primary indicating elements, and these only: 1 gallon, a multiple of the gallon, $2 \frac{1}{2}$ gallons, or a binary submultiple of the gallon, that is, the quantity obtained by dividing the gallon by the number 2 or a power of the number 2: Provided, however, That a device may be constructed to deliver other amounts than the above, corresponding to predetermined money values ai a definite price per gallon, but in such cases the device shall be so constructed that the price per gallon at which it is set at any time will be clearly indicated to the customer by automatic means. Fractional parts of a gallon may be indicated in terms of decimal or binary-submultiple subdivisions. In the case of a wholesale device, the value of the smallest unit of indicaied delivery shall not exceed 1 gallon.

(The specification as proposed by the committee, was duly adopted.)

Mr. HoLвrooк. The next specification is to be applicable to retail devices only.

5. Device to Indicate When System Is Properly Filled.-Retail devices other than those of the visible type shall be equipped with a device which will indicate whether or not the system is properly filled before a delivery is begun. This specification shall not be construed to prohibit a manually-operated valve in the standpipe, but shall prohibit a check valve in the discharge line in such a position that the partial emptying of the system would not be disclosed: Provided, however, That a checi valve in the discharge line shall be permitted when an efficient air eliminator or other means is provided to prevent inaccuracies of measurement due to air or vapor in the liquid.

(The specification as proposed by the committee, was duly adopted.)

Mr. Ноцвооок. The next specification is entirely new material.

Prevention of Registration of Air.-In any installation of a meter-type liquidmeasuring device, adequate means shall be provided for preveniting the passage of air or vapor through the meter. When gravity discharge is employed, if a mechanica? air eliminator or other means to prevent inaccuracies of measure due to air or vapor in the liquid be not provided, provision shall be made for preventing a vortox at the point of discharge from the supply tank whereby air might be drawn into the line leading to the meter, and the meter shall be so mounted and the piping so arranged that the meter will not be drained of liquid during normal operation and that air will not be trapped in the meter inlet when the supply tank is filled. In a pump-discharge unit a mechanical air eliminator or other means shall be installed adjacent to the meter inlet. 
The air eliminator or other means shall be considered effective if the provisions of specification 8 are complied with.

(The specification as proposed by the committee, was duly adopted.)

\section{Mr. HolbRook (reading):}

8. Constancy of Delivery.-The amounts delivered by any liquid-measuring device shall not vary from the standard by more than the tolerances hereinafter provided (1) irrespective of whether the discharge of liquid is continuous or intermittent, (2) irrespective of the speed at which the device is operated, except that when operated considerably faster or slower than normal speed of operation the tolerance shall be applied in deficiency only-that is, the device shall not be deemed to be incorrect by reason of the tolerance in excess being exceeded during such unusual methods of operation-and (3) irrespective of the time elapsing between operations, subject to the conditions of the special elapsed-time test described below.

A special elapsed-time test shall be made to determine whether the device is satisfactory with respect to condition (3) above. In order to comply with this test the condition of the device shall be such that the error resulting from the nonuse of the device does not exceed 2 cubic inches per hour in the case of a retail device and 5 cubic inches per hour in the case of a wholesale device: Provided, however, That in the case of a new device the permissible errors shall be one-half the values given above.

"Normal speed of operation" shall be construed to mean that range of operating speeds which may reasonably be employed in ordinary commercial usage; in the case of meters used for the purpose of determining the quantity of liquid delivered to an individual purchaser, this shall mean operation within the limits of the discharge rates ordinarily developed under conditions of installation recommended or specified by the manufacturer for the particular type of meter under test, and all such meters shall be legibly marked to show the maximum discharge rates under normal conditions of installation and the minimum discharge rates and the maximum working pressures for which they are intended to be used: Provided, however, That in lieu of the maximum rate the words "full flow", or similar and suitable words may be used: And provided further, That in the case of retail devices the value of the minimum rate shall not exceed 7 gallons per minute, and in the case of wholesale devices not exceeding $21 / 2$ inches in size, the value of the minimum rate shall not exceed 20 gallons per minute. On meters larger than $21 / 2$ inches in size the value of the minimum rate should be governed by the character of use of the meter.

Notes.-In the special elapsed-time test described above, allowance shall be made for errors due solely to a change in volume of the contained liquid, resulting from temperature variations alone, since an error of this character is unavoidable in the case of volumetric measurements of this kind when the apparatus is standing unused. This change in volume due to temperature variations is, however, small in amount for all ordinary variations of temperature, amounting in the case of gasoline to about 0.6 percent for each $10^{\circ} \mathrm{F}$ change of temperature, or about 1.1 percent for each $10^{\circ} \mathrm{C}$ change of temperature.

In applying the elapsed-time test outlined above it is recommended that the delivery be not made through a hose, since the amount of gasoline necessary to wet the inside of the hose will cause an additional shortage in the delivery.

All meters encountered in the field should be tested at the maximum discharge rate developed under the conditions of installation actually employed regardless of whether this rate exceeds or is less than the maximum discharge rate marked on the meter, and also either at the rate of 7 gallons per minute, for retail devices, or at the rate of 20 gallons per minute, for wholesale devices not exceeding $2 \frac{1}{2}$ inches in size, or at any lower discharge rate marked by the manufacturer.

The specification has been modified only insofar as is necessary to incorporate appropriate provisions for meters of the wholesale type.

(The specification as proposed by the committee, was duly adopted.)

\section{Mr. Holbrook (reading):}

9. Indicating and Registering Parts.-Counters, graduated scales and dials, and reading faces, used on liquid-measuring devices to tally sales and deliveries to individual purchasers or to indicate the amount delivered when any portion 
of the cycle or stroke has been completed, or the unit price or the total price thereof, shall be of such size and style and shall be so located and disposed that they are clearly visible to and readable by the customer from any position which he may reasonably be expected to assume; in the case of a retail device this position shall be construed to mean any position within a field of 120 degrees, defined by two vertical planes each at an angle of 30 degrees with the counter, graduated scale or dial, or reading face, and passing through the center thereof. The graduations shall be of such character and arrangement that the major ones are more prominent than and are clearly distinguishable from the minor ones. In all types of liquid-measuring devices which have a graduated scale which at some point or points or at all points constitutes the sole or most sensitive means of determining the amount of liquid discharged, the width of the graduation marks shall not exceed $0.04 \mathrm{inch}$.

That specification has been modified in two respects: First to make it applicable to the new computing units; second, to define the position which may be said to be reasonable for the purchaser to assume during a delivery.

(The specification as proposed by the committee, was duly adopted.)

\section{Mr. НоцвRоок. The next specification is new material.}

Interlocking of Registering Elements.-A liquid-measuring device in which is incorporated (1) a computing mechanism which indicates the total price of the amount of commodity delivered, for one of a series of unit prices for which the mechanism is set, and (2) a unit price mechanism by means of which one of the various unit prices is displayed on the device, shall be so designed and constructed that these two mechanisms are mechanically interlocked so that when the computing mechanism is set for a certain unit price, this unit price and no other shall be displayed on the device.

(The specification as proposed by the committee, was duly adopted.)

Mr. Holbrook. Now I have one amendment to propose to material not in your hands. That is an amendment to specification 10 . The following words are suggested to be added, at the end of the present specification:

or if the construction is such that the indicator and the graduations are in the same plane, then there shall not be a separation of the ends of the graduations and the end of the indicator of more than 0.04 inch, this distance to be measured along the line of the graduations.

It is customary in our specifications referring to indicators and graduations to have that language included, and it is proposed to be included here to make our various codes uniform in this respect.

(The amendment was duly adopted.)

Mr. Holbrook. The next amendment to be proposed is also not in your hands. It is proposed to amend specification 12 by incorporating therein the words "which is intended to be stationary in the normal use of the device" to make the specification read as follows:

12. Graduated Scales. - When a liquid-measuring device is provided with a graduated scale or dial which is intended to be stationary in the normal use of the device, this shall be riveted to its supports or otherwise permanently fixed in position: Provided, however, That in the case of liquid-measuring devices of the gauge-glass type a sliding scale will be permitted when the displacement of such scale is, by suitable means, automatically prevented at all times when liquid is being discharged from the delivery outlet.

That is purely a corrective amendment. The original meaning of the paragraph is unchanged.

(The amendment was duly adopted.) 
Mr. Holbrooк. The next specification is intended to apply only to retail devices.

16. Return of Indicating Element to Zero.-Retail devices shall be so designed and constructed that the indicating elements used to tally sales and deliveries to individual purchasers or to indicate the amount delivered when any portion of the cycle or stroke has been completed, or the unit price or the total price thereof, shall be returnable readily to a definite and clear zero indication before the next delivery is begun. Means shall be provided to prevent the indicating element from being returned beyond the zero graduation. The indicating elements may be advanced only by the mechanical operation of the device itself: Provided, however, That the device may be cleared by advancing the indicating elements, but in this event the registration shall be obscured and remain obscured until the zero is reached.

(It was moved and seconded that the specification as proposed by the committee be adopted.)

Mr. RaGLAND. Mr. President, I am going to ask to amend that section, prompted by being so much influenced by a demonstration given us by one of the oldest men of this conference, a man loved by everybody, a friend of every scale man and every weights and measures man, and an old sealer himself. I think the amendment I am going to offer will be satisfactory to the specifications and tolerances committee, because they have labored under a false idea. That idea has been entirely removed here today. If I am making a mistake, $\mathrm{Mr}$. McBride, please correct me.

At the end of the first sentence following the words, "before the next delivery is begun", I move the insertion of the words, "and means shall be provided to prevent the delivery of another sale until the indicator has been returned to zero."

I am going to ask that, and then I am through.

Mr. HolBROoK. The committee gave consideration to the amendment proposed by Mr. Ragland, and found out that there was a patent situation involved with which the committee was not familiar. Moreover, the committee did not have time to determine what effect that amendment would have upon the various devices in use and now being manufactured. The committee decided to its own satisfaction that it would be preferable to wait another year before making any recommendation whatever to the Conference in this regard.

Mr. HARRISON. If I read this correctly, the committee proposes that the "unit price" be returnable readily to zero before the next delivery is begun. I hardly think the committee intended that.

Mr. HоцвRоок. The words "or the unit price", do not belong there. Thank you, Mr. Harrison.

The Chairman. 'The motion before the house, then, is to insert after the word "begun" in the first sentence, the words "and means shall be provided to prevent the delivery of another sale until the indicator has been returned to zero" and to eliminate the words, "or the unit price."

(The question was taken and the motion was agreed to.)

Mr. HоLвRоок. On a point of information: Are the words added by Mr. Ragland to be retroactive or nonretroactive?

Mr. Rogers. I move you they be nonretroactive, on account of the number of devices on the market that do not comply with the specification as amended. 
(The motion was seconded, the question was taken, and the motion was agreed to. $)^{11}$

Mr. HolbRook. The next specification refers to retail devices only.

26. Computing Charts.-When retail devices are equipped with money-value computing charts these shall be made in accordance with one of the following principles:

(a) If the device is so designed and constructed that it purports to compute for one or for a series of unit prices the total price for every delivery within the range of the device, then the device shall be equipped with a value pointer or indicator and value graduation marks and figures; and in any position which the indicator or pointer and the value graduation marks and figures may assume, the total price of the amount delivered shall be clearly, definitely, and correctly indicated. The value graduations shall not exceed 1 cent at all prices per gallon up to and including 30 cents. At any higher price per gallon the value graduations shall not exceed 2 cents: Provided, however, That nothing in the above shall be construed to prevent the placing of a special value graduation to represent each 5-cent interval. These special graduations may take the form of dots, staggered graduations, or similar forms. They shall be so placed that their meaning and value may be clearly understood, but they shall not be placed in the space between the regular graduations.

Paragraph (b) of this specification is not proposed to be amended.

(The specification as proposed by the committee, was duly adopted.)

Mr. Houbrook. We now have a group of specifications intended to be applicable only to wholesale devices. 'This material is all new.

Indication of Delivery.-Wholesale devices shall be so designed and constructed that the amount delivered shall be clearly and definitely indicated.

(The specification as proposed by the committee, was duly adopted.)

Mr. HoLвRоок (reading):

Sensitiveness.-Wholesale devices shall be so designed and constructed that they can readily be operated to deliver an amount of 50 gallons within the tolerances on such amount hereinafter provided.

(The specification as proposed by the committee, was duly adopted.)

Mr. HoLbRook (reading):

Testing Drafts.- In the test of a wholesale device, the minimum testing draft shall be 50 gallons.

Note.-In general it is recommended that in the case of wholesale devices having high discharge rates the size of the regular testing draft should be increased to 100 or even several hundred gallons. The greater the discharge rate the more desirable it is to increase the size of the testing draft.

(The specification as proposed by the committee, was duly adopted.)

Mr. HoLBRooK (reading):

\section{TOLERANCES}

Except in special tests described above, the tolerances to be allowed in excess or deficiency on all liquid-measuring devices shall be the values shown in the following table: Provided, however, That the manufacturers' tolerances or the tolerances on all new liquid-measuring devices shall be one-half of the values given: And provided further, That these latter tolerances shall also be applied to all devices which are being retested after having been found incorrect and subsequently adjusted or repaired.

11 For final action of the conference on specification 16, see p. 101 . 


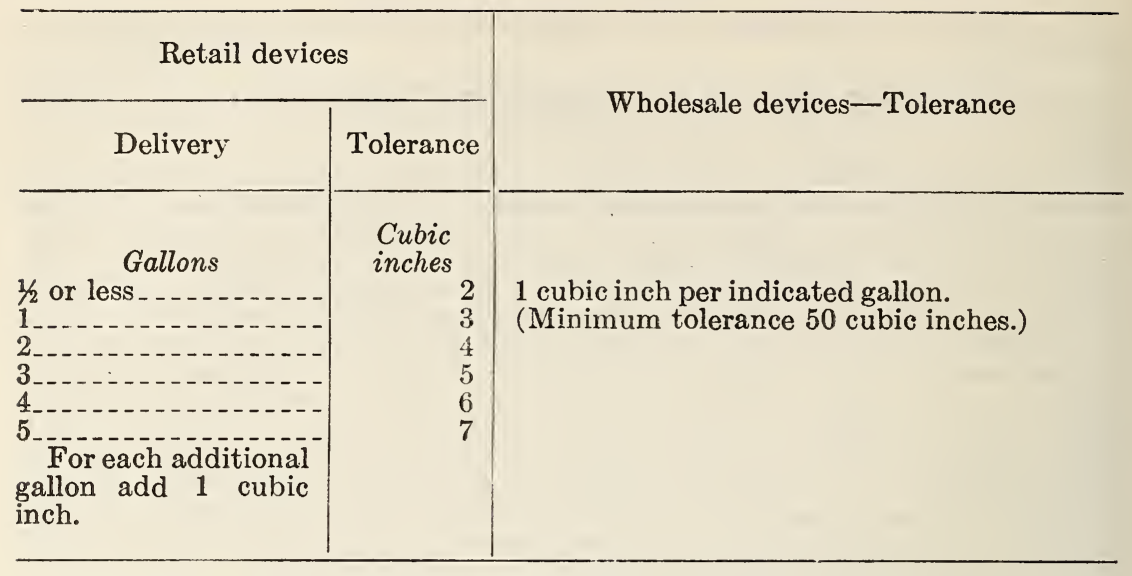

(The tolerances as proposed by the committee, were duly adopted.)

\section{MOTOR-TRUCK SCALES AND NATIONAL SCALE MEN'S ASSOCIATION ACTIVITIES}

By M. J. J. HARrison, Chairman, Committee on Yards and Terminals, American Railway Engineering Association

Mr. President and gentlemen of the Conference, while I am entitled on the program of this Conference as chairman of the committee on yards and terminals of the American Railway Engineering Association, and while much of what I may say this afternoon may be from the point of view of that organization, a complete discussion of the topic assigned me requires that I go beyond the scope of any single organization. With your indulgence, therefore, I shall attempt to discuss the subject of "motor-truck scales" somewhat broadly, and to indicate to you some of the more interesting and important steps in the development and progress of designing and testing this class of weighing equipment which have been originated and sponsored by organizations other than your own.

First of all, it might be timely to explain why a railway organization should apparently be interested in a facility which is, at least at first thought, primarily an adjunct to highway transportation. Secondly, a word of explanation as to why a railway employee should be asked to speak to you on this subject might be appropriate. Such comments seem especially fitting because, as far as I personally recall, the activities of the American Railway Engineering Association as related to the aims of this Conference have not previously been formally brought to your attention, and, further, because I note the presence of many new faces in your present gathering-to the owners of some of which it may not have occurred that the railways of the country took any active interest in the design of weighing equipment.

The American Railway Engineering Association is a voluntary organization composed of some 2,000 members who are engaged in railway work in an engineering capacity or who are otherwise eligible to membership in the Association. Organized in 1899, it existed as an independent body, although informally allied with the American 
Railroad Association until 1920. At that time, at the termination of Federal control of railways and with the general reorganization of the American Railroad Association which then occurred, the American Railway Engineering Association was, to all intents and purposes, constituted the Engineering Division of the American Railway Assotion. With the further reorganization of the American Railway Association in 1934, the American Railway Engineering Association became substantially the Engineering Division of the Association of American Railroads.

Since at least 1912 the Association of American Railroads, by whatever name it was known or however it was organized, had given formal attention to weighing and to weighing equipment, concentrating in the earlier days on track scales. When the American Railway Engineering Association became a virtual unit of the American Railway Association in 1920, the work of preparing the track-scale specifications subsequently issued by the National Bureau of Standards as its Circular 83, had just been completed, and there existed within the Engineering Association a small group which, as a subcommittee, had collaborated in that preparation. It is possible that knowledge of the existence of that group prompted the executives of the newly reorganized American Railway Association to allocate in 1920 to the American Railway Engineering Associa tion, as its engineering division, the handling of matters pertaining to weighing equipment. In any event, this allocation was made, and in the American Railway Engineering Association the subject was assigned to the standing committee of which I have the present honor to be chairman-the committee on yards and terminals.

The American Railway Engineering Association, having finished a work of considerable importance with the completion of its contribution to Circular 83, and feeling that, at least for the time being, there was nothing further to be done or said in connection with railway track scales, turned its attention to other forms of weighing equipment used by railways. Substantially the same reasons which had prompted the preparation of specifications for track scales suggested the preparation of specifications for other types of scales, and the result was a document, produced by the subcommittee mentioned a moment ago, and adopted and issued by the Association in 1923, under the title "Specifications for the Manufacture and Installation of Motor Truck, Built-In, Self-Contained and Portable Scales for Railway Service."

In presenting its report to the Association, the committee said, in part-

While your committee was not expressly directed to consider the subject of motor-truck scales, it became apparent that the now heavy current use of motor trucks made such consideration highly pertinent, particularly as specifications for motor-truck scales have so many provisions in common with the various types of depot scales. Your committee, therefore, so drafted its specifications as to include the essential provisions for standard motor-truck scales.

The problem of selecting standard sizes and capacities for motor-truck scales is somewhat different from that of the other types of scales, as no great variety has yet been manufactured.* Considerable data was collected as to all motortruck scales now in use or contemplated, and as to present and prospective highway-bridge and roadway limitations, and it was found that the essential types of motor-truck scales naturally fell into three main classes or capacities,

\footnotetext{
* It should be kept in mind that this paragraph was written in 1922.
} 
i. e., for the 31/2-ton trucks, the 5-ton trucks, and the 71/2-ton trucks. A study was made as to the spacing of wheels, disposition of loads on the axles, and the amount of overload used, and typical diagram was prepared for each class of trucks.

The report then goes on to explain the reasons for selecting the various platform sizes and scale capacities which were set forth in the specifications as standard for railway service-in nther words, the preferred sizes and capacities.

It will be noted from the excerpt just quoted that some doubt must have existed in the minds of the committee members as to the advisability of including motor-truck scales in their proposed specifications. However, the fact remained that the railways used a great many such scales, particularly at team track yards, and it was doubtless for this reason that the committee concluded to make its specifications inclusive.

In all frankness, it must be noted that the scale manufacturers were not entirely in sympathy with the specifications as adopted by the Engineering Association. There was a variety of reasons for this lack of complete sympathy, but this variety could be reduced in the final analysis to a dollars-and-cents basis. To explain: The 1923 specifications drew a very sharp distinction between scales of the motor-truck type and scales of the wagon type, and were largely predicated on the basic principle that the stresses produced in a scale structure by a loaded motor truck were materially greater than could be produced in the same scale structure by a wagon of equal gross weight. For this reason, therefore, for the same weigh-beam capacity, a motor-truck scale conforming to the 1923 specifications of the American Railway Fngineering Association had to be of materially heavier construction than a so-called wagon scale of the same period. This, together with the fact that certain refinements of design and construction-all necessary in the judgment of the committee for enduring accuracy in the scale and for economical maintenance-were specified, made for a higher manufacturing cost (and a consequently higher selling cost) than the manufacturers were then willing to agree to. This situation led to the offering for sale by the manufacturers of two rather different lines of motortruck scales, one spoken of as the "specification" line, the other spoken of as the "commercial" line. The specification line was the higher priced, and was considerably superior in quality. On the other hand, the commercial line, being lower priced, was easier to sell, especially in competition, since the prospective purchaser's immediate intelligent interest was often limited to two thingsnominal capacity and first cost.

That this situation was disappointing can be easily understood. It is true that the original subcommittee had had clearly in mind the fact that, after all, they were writing specifications for railway application At the same time, a sincere effort has been made to take a broad view of the situation-with the hope that the principles of design embodied in the specifications and the preferred sizes and capacities listed therein would become nationally acceptable. It is not out of place to note here that the subcommittee which prepared these specifications actually was and is, the only organized technical group in the United States which might with any justification write scale specifications from the "user" point of view. Furthermore, the subcommittee had had the benefit of collaboration from both the $\mathrm{Na}$ - 
tional Bureau of Standards and the National Scale Men's Association, and the further benefit of assistance on the part of technical representatives of the scale manufacturers. In addition to this, the specifications had been promulgated by the National Bureau of Standards as its Letter Circular 152.

In the mean time, however, the art of motor-truck design was progressing rapidly. Also, more and more attention was being paid by State highway officials to damage to pavements and bridges by overloaded trucks, and the matter of cost of highway structures adequate to carry the steadily increasing wheel loads became a serious economic problem. It appeared inevitable that a point must be reached, beyond which the weights of loaded highway vehicles might not go, and this was finally brought about through the American Association of State Highway Officials, whose recommendations have found expression in the legislative actions of many of the States.

At about this same time, the Federal Government started to purchase motor-truck scales and, for lack of anything else, specified conformity with the provisions of Bureau of Standards Letter Circular 152 , which, as I have already mentioned, was the code of specifications originated and adopted by the American Railway Engineering Association. When proposals to furnish these scales were received from the various contractors and when such proposals were carefully analyzed (as is obligatory in the case of Federal purchases under any set of specifications), it was found that there were a number of points in the specifications as to which interpretation was necessary, and that interpretation frequently led to undesirable controversy. In short, on that count, the specifications were not satisfactory as a basis of contract.

After careful consideration of all the related facts, our subcommittee on scales decided, in about 1932, to undertake a general revision of the motor-truck scale specifications, and in March 1935, a new code of specifications for motor-truck scales was presented to and adopted by the American Railway Engineering Association. This was, of course, a substitute for the former code, adopted in 1923, which was withdrawn. In the preparation of the 1935 specifications, the subcommittee again had the benefit of collaboration by representatives of the National Bureau of Standards and members of the National Scale Men's Association, and in addition had closer cooperation on the part of the scale manufacturers than had been the case 12 years previously.

Fundamentally, the 1935 specifications prescribe the loadings promulgated by the Association of State Highway Officials, and are much more explicit than the former specifications in some matters, particularly with respect to weigh-bridge design. The list of preferred sizes and capacities is somewhat larger than was included in the 1923 code, nine different scales being now included in this group, while of additional interest is the fact that provision is made for the special condition of loading produced by the tractor and semitrailer combination. $\Lambda$ t the present time, I am happy to say, there is every prospect that these new specifications are being and will be much more favorably received than were the 1923 specifications, and the American Railway Engineering Association is optimistic that its latest effort in this line will serve to bring about a desirable improvement in the quality of motor-truck scale installations in the country 
as a whole. If it has not already been done, the attention of the $\mathrm{Na}$ tional Bureau of Standards will be formally called to the adoption of this new code, and it is hoped that the Bureau will see fit to withdraw its Letter Circular 152 and substitute therefor the new material.

In concluding this section of my remarks this afternoon, it is fitting that mention be made of the fact that specifications such as those about which I have been speaking are somewhat different in character than are the various codes of specifications adopted by this Conference, without, however, conflicting in any way therewith. In other words, the codes adopted from time to time by this Conference are intended to insure: (1) That devices are so made that they may readily be used for the purposes intended without the introduction of elements which would be detrimental to the accuracy of the results or to the interests of buyer or seller; (2) that devices are so made that they are reasonably permanent in their indications and adjustments; and (3) that devices are not so made that they are conducive to the perpetration of fraud. From the very nature of things, howerer, the specifications of this Conference must be general in character-they cannot be detailed. On the other hand, the specifications produced by the American Railway Engineering Association are intended as a detailed basis for purchase. They are intended to result in scales of the same quality or, if you please, value, being furnished for similar service. To state it in yet another way, they are intended to result in similar scales being furnished by any manufacturer under the same proposal. Hence, they go into such matters as details of loading, as working stresses for the materials ordinarily used in scale manufacture, as design loads for a given size of platform and a given weigh-beam capacity, as weigh-beam graduations, etc. They provide for an acceptance tolerance entirely consistent with that specified in Bureau of Standards Handbook M85, but, being intended as a purchase specification, are entirely silent in the matter of maintenance tolerances. However, the fundamental basis for the specifications is that compliance with their provisions shall result in a weighing machine which will more economically and for a longer period of time continue to reflect correct weights of motor trucks within the limits of error permitted by the tolerances adopted by this Conference, subject only to the proviso that the loads applied on the scale do not exceed those for which the scale is designed.

Mention of maintenance tolerances brings me to another phase of this subject, and to the activities of another organization which parallel and supplement those of this Conference. I refer now to the National Scale Men's Association, an organization which is presumably better known to the members of this Conference than is the American Railway Engineering Association, and whose interest in matters pertaining to highway weighing equipment is more easily understandable.

Something over a year ago, the attention of the National Scale Men's Association was formally called to the fact that there were often considerable disparities between weights of the same load as indicated by two different motor-truck scales, both of which had been approved by the weights and measures official having jurisdiction. In other words, taking a given load consisting of a heavily loaded motor truck, if this load were to be weighed on one motor-truck 
scale, and immediately taken to a second scale and weighed, there would frequently be a considerable difference, even though both scales had recently been "sealed." To state the matter in yet another way, it appeared that large-capacity scales which had been tested and sealed by the weights and measures official would not necessarily weigh alike under practical conditions of use.

The National Scale Men's Association appointed a committee to look into this matter, and this committee (of which I was named chairman) gave the subject thoughtful consideration, finally concluding that much of the difficulty arose from the lack of adequate testing equipment on the part of those charged with the responsibility of seeing that the scales were weighing correctly.

This is a matter which has previously been brought to the attention of this Conference. To review briefly, it is a known fact that, in entirely too many jurisdictions, the quantity of available test weights is quite inadequate for an intelligent determination of the weighing performance of large-capacity scales, such as those of the motor-truck type, especially in the important upper range-that is to say, in the commodity-weighing range of the scale capacity.

With this in mind, the committee just mentioned set to work to define an adequate test of a motor-truck or a wagon scale. It prepared a report, which was submitted for discussion at the annual convention of the National Scale Men's Association 2 weeks ago, and which was given tentative approval after slight modification. It is the present desire of the committee to submit its preparation to this Conference (possibly through your Committee on Specifications and Tolerances), to the end that a mutually acceptable code may be agreed to and adopted. The National Scale Men's Association committee has been directed so to negotiate.

Rather than take up your time this afternoon by reading the entire proposed code, I would like to bring to your attention certain of its more important points. The code opens with the statement that an "ideal" test of a motor-truck or wagon scale would be a test to its full nominal capacity, using test weights exclusively. As a practical substitute, it is then pointed out that this can be approximated under favorable conditions by the use of an adequate quantity of test weights in conjunction with one or more "strain loads." Attention is directed to the fact that the test, to be satisfactory, must extend through the commodity-weighing range of the scale.

The next statement has to do with the minimum quantity of test weights of known value which can be considered as satisfactory for routine use with strain loads, and this is defined as 25 percent of the nominal capacity of the scale under test, with an upper limit of 10,000 pounds. It should be understood, of course, that this is not intended to prevent or discourage the use of more than 10,000 pounds of test weights if they are available; the reference is merely to the minimum requirement.

The value of the strain load or loads is then stated in this way: One strain load is to be used in any event when only part of the nominal capacity of the scale is represented by test weights, and the value of this strain load is required to be such that "strain load" plus "test weights" will at least equal the gross weight of the heaviest loaded vehicle weighed on the scale under test. Attention is called 
to the fact that this total test load will generally approximate the nominal capacity of the scale.

$A$ second and intermediate strain load is then required to be provided and used if the value of the first strain load exceeds twice the value of the test weights used in the test. As an illustration of how this would work in practice, let me state two examples.

Assume a scale with 24,000-pound nominal capacity, a maximum load to be weighed of 20,000 pounds, and 6,000 pounds of test weights available. One strain load must equal at least the difference between 20,000 and 6,000 pounds, or 14,000 pounds; 14,000 pounds, however, exceeds twice 6,000 pounds. Therefore, an additional strain load of approximately 6,000 pounds is required to be secured and used.

Assume, on the other hand, the same scale and the same maximum load to be weighed, but 10,000 pounds of test weights available and used. Under these assumptions, the strain load is required to weigh not less than 10,000 pounds, and no intermediate strain load is required.

With this statement of required loads, the code then goes on to detail the test procedure, in which there is nothing unusual except a rather definite statement to the effect that "corner tests" need not be made except for information in the event repairs or adjustments to the scale are necessary. The performance requirements are then stated substantially as they appear in Handbook M85 of the National Bureau of Standards, with the exception that the largest permissible value of the SR is stated in pounds as well as in terms of the value of the weigh-beam graduations.

The code then calls attention to certain miscellaneous details which are of importance, and concludes by citing the fact that several testing agencies have demonstrated the economy of using test weights of 500- and 1,000-pound denominations instead of the more usual 50 -pound weights, and pointing out the necessity for providing appropriate means of transportation and devices for handling these larger weights.

It seems to the National Scale Men's Association that weights and measures officials cannot afford to ignore the fact that motor-truck weights have enormously increased, that motor-truck scales have correspondingly increased in size and capacity, and that the testing of these scales with a small quantity of test load does not necessarily correctly indicate the weighing performance of such scales under practical conditions of usage. The members of the Scale Men's Association frequently find themselves, if you please, in the position of holding the bag when the same vehicle fails to weigh the same on two different "sealed" scales. They have, through their committee, formulated a code designed to obviate their present practical difficulty in the matter, and earnestly request the support of this Conference in correcting existing faulty conditions.

This, gentlemen, concludes what I have to say at this time on the subject of Motor-Truck Scales, having indicated to you what one organization is doing to raise the standard of new installations, and what another organization is doing to bring about accuracy in existing as well as future installations.

At the suggestion of your secretary, I would now like to report briefly for the information of this Conference some of the activities 
and accomplishments of the National Scale Men's Association since this Conference last met.

At the 1931 meeting of this Conference, the then secretary of the Scale Men's Association spoke of certain standardization work performed up to that time by his association, and mentioned specifically: (1) A code of specifications for the overhaul and repair of largecapacity scales; (2) a code of specifications for railway track scales for light industrial service; (3) a standard form for use in reporting tests of railway track scales and especially adapted for use by organizations which exchange reports of this character; and (4) a code of specifications for railway track-scale test-weight cars.

Since their preparation and adoption by the Scale Men's Association, the specifications for railway track scales for light industrial service have been endorsed by the American Railway Engineering Association, while the specifications for railway track-scale testweight cars have been submitted to and adopted by the American Railway Engineering Association.

Since 1931 the National Scale Men's Association has completed: (1) A definition of a standard test of a railway track scale, which was subsequently adopted with slight modification by the American Railway Engineering Association; (2) a code of rules to govern the operation and maintenance of railway track-scale test-weight cars, which was likewise adopted with slight modification by the American Railway Engineering Association; and (3) a definition of a standard inspection and test of a hand-operated grain hopper scale, the status of which is expected to be advanced through contacts with authorized grain-weighing agencies. Other projects under way at the present time include the definition of a standard test of a motor truck or wagon scale (to which I have made reference earlier in these remarks), the preparation of a standard form for reporting tests of grain hopper scales, and the preparation of a standard glossary of scale terms. Progress has been made on each of these projects.

Both the American Railway Engineering Association and the National Scale Men's Association desire that the National Conference on Weights and Measures be assured that, in their respective fields, the aims of both associations are the same as the aims of the Conference - the continued advancement of accuracy, efficiency, and uniformity in weighing and in weighing equipment. May the three groups continue in the future as they have in the past to supplement each other's efforts to the common end.

The Chairman. Thank you, Mr. Harrison.

\section{A BOARD OF ADJUSTMENT}

By Edwin C. Emhardt, Supervisor, Bureau of Weights and Measures, Philadelphia County, Pennsylvania

Mr. Chairman and gentlemen of the National Weights and Measures Conference, I was put in office in Philadelphia about a year ago. I had nothing to guide me, except a little publication of the National Bureau of Standards given to me by Ralph Smith, entitled "Handbook 11, Weights and Measures Administration." By this book, my thought about weights and measures administration was directed to. the fact that it is twofold. It is both regulatory and supervisory. A good deal of the discussion you have today concerns the regulatory 
measures which are most important. If you could control the manufacturer of machinery that dispenses articles, so well that those machines would dispense without any chance of fraud, then your supervisory measures would become relatively unimportant. But when I read this book, I found that so much is put up to the weights and measures official, that his office becomes a very responsible one. Especially was it emphasized that supervisory work should not be neglected.

One of the important phases of supervisory work is the prosecution of offenders against the weights and measures laws. It appears that the matter of prosecutions is one which is especially susceptible of not being properly administered. When I took office, I was confronted with a situation, which, perhaps, is found to exist in any large city. Many thousands of violations were reported, and very few prosecutions resulted from these violations. I found that in 1 year there had been reported 18,000 violations, and as a result of that, there were just 49 prosecutions. So I was bound to give thought to the question as to how decisions as to prosecutions were to be arrived at, and especially whether this decision should rest on the judgment of one individual - the weights and measures official.

Now I have in mind, for instance, that there might be a wonderful judge who was very learned in the law, and yet if that judge were given entire authority, it might be that no crime would be adequately punished by that man. He might not have learned to take the responsibility of punishing even a murderer, adequately. So my conclusion was that you cannot safely leave the decision to an individual. Especially did I desire to avoid the responsibility of making these decisions myself. Frankly, gentlemen, I don't think I could prosecute anybody of my own free will. I could always find an excuse for a man-it is his first offense; he might have a family of 10 children; or it might be something else.

But in order to get away from this situation of having one person decide it, we had to devise some other plan; so this is the way we arrive at it. I think that such a plan should be adopted in every jurisdiction.

We have formed in the city of Philadelphia a group of men which we call an "adjustment board." This body is an entirely new feature in the administration of weights and measures inspection. Philadelphia's board hears all cases of violations of weights and measures regulations, having the authority to take action in one of two ways. It may either make summary adjustments of cases at the time of their hearing before the board, or it may decide that legal proceedings are necessary and direct that such cases be prosecuted in the courts. The action of any member outside of the bureau is, however, only advisory.

One of the most pertinent problems in the bureau's work is that of dispensing with legal violations. While rigorous inspection and complete record systems are essential components of administration, their effectiveness may be minimized if proper enforcement of the statutes enacted to protect the everyday buyer is lacking. Likewise, the possibility of stringent prosecutions for minor offenses also has its disadvantages. The burdening of magistrates with unnecessary work and the needless interference with merchants and dealers may 
easily result in a general lack of cooperation with the work performed by the bureau. On the other hand, there is the ever-present pressure on the part of friends, political or otherwise, to intercede for violators of the ordinances enforced by the bureau.

The advisability of giving the bureau supervisor authority to make final decisions on such minor violations is decidedly questionable. The supervisor is subjected to political influences, and it is doubtful whether such an appointed officer should be given broad administrative powers without the provision of adequate safeguards to prevent the abuse of his authority. In one instance his action might be unnecessarily severe, while in others it might be weak or lenient, due to a fear of offending those interceding for the violator.

The handling of violations, therefore, and primarily those not demanding immediate legal action, has been vested in an impartial and unofficial adjustment board of 17 members. In addition to the bureau supervisor, deputy supervisor, and five district supervisors, the board's membership includes representatives of the following organizations: Retail Grocers' Association, Meat Dealers' Association, Philadelphia Commodity Administration, Reading Terminal Market Association, Fish Dealers' Association, Petroleum Code Administration, Chicken Dealers' Association, Coal Conference of Philadelphia, Coal Truckers' Association, and Coal Code Authority.

The board receives all the records of violations as transmitted by the district supervisors. At its meetings, held weekly on Tuesday morning, all cases are heard and the action to be taken in each instance determined. In many cases the board itself makes satisfactory adjustments, following which the violators are released with proper reprimands and detailed instructions regarding the practices to be followed in the future. In cases where the board decides that legal proceedings shall be instituted, affidavits are drawn and forwarded to local magistrates for hearings.

That the work of the board is of large volume and importance is evident. Of the 6,804 violations recorded during the year, a total of 3,142 , or approximately 46 percent, were summarily adjusted by the board at the time of hearing. As a result of these adjustments the number of legal prosecutions has been reduced to a minimum.

The accompanying tabulation, which summarizes the prosecutions by classes and indicates the corresponding totals for fines collected, indicates that violations of a more serious nature are prevalent throughout the city and that many are being prosecuted.

Summary of total prosecutions, with fines and costs collected, year ending Apr. \$0, 1935

\begin{tabular}{|c|c|c|}
\hline Field of violation & $\begin{array}{l}\text { Number of } \\
\text { prosecutions }\end{array}$ & $\begin{array}{l}\text { Fines and costs } \\
\text { collected }\end{array}$ \\
\hline $\begin{array}{l}\text { Commodities . } \\
\text { Gasoline } \\
\text { Scales. } \\
\text { Coal } \\
\text { Purchases }\end{array}$ & $\begin{array}{r}403 \\
109 \\
32 \\
1,121 \\
532\end{array}$ & $\begin{array}{r}\$ 2,678.00 \\
1,080.00 \\
387.00 \\
13,404.00 \\
1,064.40\end{array}$ \\
\hline Total & 2,197 & $18,613.40$ \\
\hline
\end{tabular}


While the tabulated record of prosecutions indicates the current need in many instances for the strict enforcement of the law for the protection of the buying public, the bureau trusts that the number of violations and the necessity for prosecutions will show a marked decrease in the future as merchants and dealers become better informed as to the regulations regarding short weight and measure and the penalties therefor.

The situation now is, that some of the things which in former years were recorded as violations, are not now included in the list of violations. For instance, we may find that a scale is off zero; or we find that certain corrections have to be made, and the scale is condemned for repairs. Now, of course, those are things that occur in the general use of scales; we would not necessarily bring that man before an adjustment board, or consider a prosecution. What we do is to consider the facts and determine whether there is a prima-facie case of violation of the weights and measures law.

I want to cite an incident which occurred this morning before I came away. There was a case of an absolutely purposeful violator, who had been ordered immediately before the board; his prosecution was ordered, and an affidavit made out. His case was numbered and put on a list which is prepared after the cases go before the magistrate, and which is presented to the board before they meet the following week so that each member knows what has happened to every case decided on the week before.

Now this morning, a person came into the office, who is one of my closest friends, a person who has spent a lot of money and a lifetime in welfare work, a fine person whom anybody would like to help. It developed that this violator was her nephew. Now, if there could be a case where we would want to serve a certain person, that particular person would be this splendid woman on account of the wonderful work she had been doing in the community. Yet there was no chance to take that case off that list without publishing it to everyone in the department, and arousing criticism. Moreover, it would have to be noted on the list presented to the adjustment board the following week. Hence the action taken will have to stand. The case goes before the magistrate tomorrow. The violator will be punished in accordance with law. You see the value of that procedure.

Gentlemen, it is an honor to work with you in this weights and measures work, and I hope you will all read our annual report for the last year. We have a supply here for you. I want to say we are all enthusiastic in Philadelphia today, to make weights and measures a real government service to all. I thank you.

The Cuairman. Thank you, Mr. Emhardt.

(At this point, at 5:14 p. m., the Conference adjourned to meet at 9:30 a. m., Friday, June 7, 1935.) 


\section{SEVENTH SESSION-MORNING OF FRIDAY, JUNE 7, 1935}

The Conference reassembled at 9:45 a. m., at the Washington Hotel, Mr. John P. McBride, presiding officer, in the chair.

\section{REPORT OF COMMITTEE ON SPECIFICATIONS AND TOLERANCES ON MODIFICATION OF SEVERAL CODES-Continued 12}

\section{MILK BOTTLES}

Mr. HoLBRook. This report was first brought before you on Wednesday morning, at which time the first item, involving the striking out the 3-pint size in the case of bottles for milk or cream, was adopted. The next recommendation also has reference to milk bottles. It involves specification 3 and the material under the heading "Tolerances." It is proposed to strike out the references to the 3-pint size in these sections. This simply follows up and completes the action taken the other day.

(The amendments were duly adopted.)

Mr. HoLBrook. The first portion of specification 3 reads as follows:

Milk bottles with an inside diameter of not over 2 inches immediately below the cap seat or stopple shall hold the correct eapacity when filled to within onefourth inch of this cap seat or stopple; bottles with an inside diameter of over this amount immediately below the cap seat or stopple shall hold the correct capacity when filled to within one-eighth inch of this cap seat or stopple.

It is recommended that the above material be amended to read as follows:

Milk bottles with an inside diameter of not over 2 inches immediately below the cap seat or stopple when one is provided, or at the top when the closure is effected by an overall cap and no cap seat or stopple is provided, shall hold the correct capacity when filled to within one-fourth inch of this cap seat or stopple or of the top respectively; similar bottles having a diameter of over 2 inches at similar points shall hold the correct capacity when similarly filled to within oneeighth inch of the cap seat or stopple, or of the top, respectively.

The following amendment is also proposed.

Tolerances. Amend by adding to the tolerance table the 1- and 2-gallon sizes with tolerances as follows:

\begin{tabular}{|c|c|c|c|c|c|c|c|c|}
\hline \multirow{2}{*}{ Capacity } & \multirow{2}{*}{\multicolumn{2}{|c|}{$\begin{array}{c}\text { Table A, toler- } \\
\text { ance on individual } \\
\text { bottle }\end{array}$}} & \multirow{2}{*}{\multicolumn{2}{|c|}{$\begin{array}{l}\text { Table B, toler- } \\
\text { ance on average } \\
\text { capacity }\end{array}$}} & \multicolumn{4}{|c|}{$\begin{array}{l}\text { Table C, special tolerance for } \\
\text { individual bottles in use }\end{array}$} \\
\hline & & & & & \multicolumn{2}{|c|}{ In excess } & \multicolumn{2}{|c|}{ In deficiency } \\
\hline 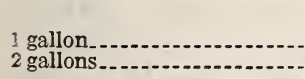 & $\begin{array}{r}\mathrm{dr}_{10} \\
18\end{array}$ & $\begin{array}{r}\text { cu in. } \\
2.3 \\
4.1\end{array}$ & $\begin{array}{l}\mathrm{dr} \\
2.5 \\
4.5\end{array}$ & $\begin{array}{r}\text { cu in. } \\
0.6 \\
1.0\end{array}$ & $\begin{array}{r}\mathrm{dr}_{10} \\
18\end{array}$ & $\begin{array}{r}\text { cu in. } \\
2.3 \\
4.1\end{array}$ & $\begin{array}{l}\mathrm{d} \mathbf{r} \\
5 \\
9\end{array}$ & $\begin{array}{r}\text { cu in. } \\
1.2 \\
2.0\end{array}$ \\
\hline
\end{tabular}

Mr. Richards. Mr. Chairman, may I say just a few words. We are in accord with the principle of this specification, but really it

\footnotetext{
12 See p. 59 for first portion of this report.
} 
isn't going to help us any. We went over this last night, and we have something to submit, a copy of which I have just handed to your reporter.

SeCRETARY's Note.-The material referred to was presented over the name of the standardization committee, Glass Container Association. It was stated that it was not possible to comply with the tolerances proposed for the 1-gallon and 2-gallon sizes, and that the following tolerances were necessary:

\begin{tabular}{|c|c|c|}
\hline Sizes & Table A & Table B \\
\hline 1 gallon 2 gallon & $\begin{array}{l}12 \mathrm{dr} \text { or } 11 / 2 \mathrm{oz} \\
32 \mathrm{dr} \text { or } 4 \mathrm{oz}\end{array}$ & $\begin{array}{l}3 \mathrm{dr} \text { or } 3 / 8 \mathrm{oz} \\
8 \mathrm{dr} \text { or } 1 \mathrm{oz}\end{array}$ \\
\hline
\end{tabular}

It was requested that the $2 \frac{1}{2}$-gallon size be added, with suggested tolerances of 38 drams or $4 \frac{1}{2}$ ounces and of $91 / 2$ drams or $13 / 16$ ounces in tables $A$ and $B$ above, respectively.

Mr. Richards. I really am compelled to object to the suggestion submitted by your committee. We studied this thing very carefully in principle. We are trying to build up, not to break down. But there are some features that are going to be an impossibility to work on, and that are going to work a hardship on everybody.

We work in cooperation with the sealers. I wrote every State sealer in the United States, and asked everyone to cooperate. We told them everything we are trying to do, but in different States they have different feelings on milk bottles.

Here is the thing which we want. It has been passed by the standardization committee of the Glass Container Association, of which I am chairman. We have filling points specified at the cap seat and at one-eighth inch and at one-quarter inch below the cap seat. What have we got to do? In the event that a bottle is correct when filled to the last-mentioned point, when it is tested by filling it to the cap seat we get no tolerance, although a tolerance is plainly stated. Take another make, correct to the cap seat; when filled to a point one-quarter inch below the seat it becomes a short bottle, and we are under bond not to deliver short-measure bottles. It is hard on us. You know we have got modern filling machines and modern. equipment, and we no longer have to fill these bottles one-quarter inch below the cap seat. If we do it leaves an unfilled space.

Concerning the 2-gallon and 1-gallon sizes, you haven't given us the proper tolerance. You realize there is an unavoidable variation in those bottles. I want to say that we have a right to have a $2 y_{2}$-gallon size; you recognize that size for another purpose. These are the reasons why I am now suggesting that we let this thing go over. I am sure the glass industry is not going to offend. We are going to do just what is right. When these specifications are amended we want them right.

Mr. Holbrook. Some time ago Mr. Richards wrote me a letter, and described this over-all cap-a cap set on the top of the bottleand requested information as to where the filling point would be on a bottle made to be used with an over-all cap. I gave it as my interpretation, that since the filling point in a bottle having a cap seat was one-quarter inch below the cap seat, the new bottle might well be measured to a point a similar distance below the new seat, which was the top of the bottle. I suggested that it would be perfectly reason- 
able to measure the capacity of these bottles and to fill these bottles, to within one-quarter inch of the top. Mr. Richards, as I recall it, replied that this was a very satisfactory solution of the whole matter. Consequently when the committee met, we worked out the proposed specification accordingly. We thought this recommendation was entirely satisfactory to the glass industry.

As I understand Mr. Richards' proposition this morning, he desires to have the customary bottle, having a cap seat, measured to a point one-eighth inch below the cap seat and bottles having a top closure, to a point three-eighths of an inch below the top. Now that is proposed for the first time-the committee has never heard this recommendation before. It represents a distinct departure from the former interpretation which was said to be entirely satisfactory. As to the present requirement that the filling point be one-quarter inch below the cap seat, I might say that some years ago, the National Bureau of Standards made an investigation of the filling of milk bottles in practice. We found that the average bottle of milk or cream was actually filled to a point one-quarter inch below the cap seat.

In view of the glass industry's desires, as stated by Mr. Richards, I will ask permission of the Conference to strike out all these recommendations of the committee, as to milk bottles, which have not as yet been acted upon by the Conference, to give the industry an opportunity to decide what it wants. The requirement of this Conference in relation to the filling point has stood unchanged for 15 years or 20 years. We can hardly reopen the matter this morning to consider this new suggestion of one-eighth inch and three-eighths inch, in the case of bottles having cap seats and bottles designed to use over-all cover caps, respectively.

Mr. Leithauser. I think the recommendation of Mr. Holbrook is very wise. I think it should go over until the milk-bottle manufacturers can present a definite recommendation for the consideration of the Conference.

Mr. RichaRDs. I just want to make one more statement, because I am airaid I didn't make myself clear. What Mr. Holbrook said in relation to the survey about the filling point is absolutely a fact. There is no question about that. We are coming out for one-eighth inch because we think the bottles will be filled more nearly to that point. All the dairy plants are equipped with modern machinery. We are not asking for more tolerance.

The Chairman. Now, gentlemen, the matter before you is the committee request for authority to strike from its recommendation the paragraphs in relation to milk bottles, which you are now considering.

Mr. O'KEEFE. I move yo' that Mr. Holbrook's request be concurred in.

(The motion was seconded, the question was taken, and the motion was agreed to.)

\section{RECONSIDERATION OF ADOPTION OF SPECIFICATION 16 FOR LIQUID-MEASURING DEVICES, AS AMENDED ${ }^{13}$}

Mr. RAgLAND. Mr. Chairman, I ask for a suspension of the rules, to reconsider our decision in relation to specification 16 , for liquidmeasuring devices. I hope the gentlemen will agree with me.

38 See p. 86. 
The Chairman. Is there any objection to suspending the regular order of business? If there is no objection, the chair will suspend the regular order of business.

Mr. RAGLAND. I move that the conference proceed to reconsider specification 16 for liquid-measuring devices, as adopted yesterday. It is my idea that the specification be adopted in the form originally recommended by the committee on specifications and tolerances. I ask for this as a matter of fairness. I rose on this floor, and proposed an amendment to you gentlemen and you agreed to it. I found out afterwards that we were doing an injustice to the manufacturers.

(The motion was seconded, the question was taken, and the motion was agreed to.)

Mr. RAGLand. Now, gentlemen, I desire to withdraw the amendment which I offered to that specification and which was adopted.

(The motion was seconded, the question was taken, and the motion was agreed to.)

Mr. Ragland. Now that leaves us in the position of having taken no action on specification 16 .

Mr. Griffith. Mr. Chairman, I will ask that the secretary read specification 16 for liquid-measuring devices as originally submitted by the committee on specifications and tolerances.

Mr. Holbrook (reading):

16. Return of Indicating Element to Zero.-Retail devices shall be so designed and constructed that the indicating elements used to tally sales and deliveries to individual purchasers or to indicate the amount delivered when any portion of the cycle or stroke has been completed, or the unit price or the total price thereof, shall be returnable readily to a definite and clear zero indication before the next delivery is begun. Means shall be provided to prevent the indicating element from being returned beyond the zero graduation. The indicating elements may be advanced only by the mechanical operation of the device itself: Provided, however, That the device may be cleared by advancing the indicating elements but in this event the registration shall be obscured and remain obscured until the zero is reached.

Mr. Harrison called attention to the fact that the words "or the unit price" were included in error, and the committee desires to strike out these words.

Mr. Griffith. Mr. Chairman, I make a motion that specification 16 be adopted as submitted by the committee, with the deletion of the words mentioned.

(The motion was seconded.)

Mr. Rogers. Mr. Chairman, I want to explain this to our delegates from the State of New Jersey because it may not be clear why we are changing this specification as adopted, and this should be considered carefully at this time. Everybody here desires the reading element of a device to come back to zero before the next delivery can be begun. I want to still sustain myself and my position on that point. However, since yesterday, I have learned a few things about the situation and the effect the amendment offered by Mr. Ragland would have, with particular reference to certain new equipment that has been made and is ready to go on the market. Before some of these companies are able to get this equipment approved by the chiefs of the departments of various jurisdictions, there is a good possibility that these specifications may be applied, and, if so, it would tie up their entire program. We are also confused on a patent 
situation. I believe, in view of this, that the question on the amendment should go over and the specification adopted as the committee recommend it.

Mr. RAGLAND. I am strongly in favor of having the gallonage, the price per gallon, and the total price, all synchronized together. I believe it is right. I believe we are coming to it. I am not going to give in a single thing. There are certain things that will be developed, and have been developed, that I knew nothing in the world about. The weights and measures men should be taken into the confidence of these men as well as the petroleum institute. I ask for the question on the motion.

(The question was taken, and the motion was agreed to.)

\section{REPORT OF COMMITTEE ON SPECIFICATIONS AND TOLERANCES ON MODIFICATION OF SEVERAL CODES-Continued ${ }^{14}$}

\section{Mr. Holbrook (reading):}

\section{LUBRICATING-OIL BOTTLES}

Tolerances.-Amend by adding 1-gallon size with tolerance of 20 drams in excess only, to the tolerance table.

(The amendment was duly adopted.)

Mr. Holbrook (reading):

\section{SCALES}

General Specifications.-12a. This specification reads as follows: "The graduations on all beams and reading faces shall be clear and distinct and in no case shall their width be less than 0.008 inch."

Amend this specification by adding at the end thereof the following: "- - except as provided in specification 12c-nor more than the width of the minimum clear interval between graduations. On any bar of a beam, all graduations shall be equal in width. The graduations on beams shall be of such character and arrangement and shall be so numbered that all weight indications may be conveniently read."

Mr. Baucom. There is just one word in there I don't feel is really all right. The word "conveniently" is a hard word to define, and when we get into court probably there will be some question as to what is "convenient."

Mr. Holbrook. I think that the word is a reasonable and proper one. If you can suggest something better, it can be considered.

Mr. LEvitT. Wouldn't the word "accurately" be a much better word than "conveniently"?

Mr. BAucom. I move that the word "accurately" be substituted for the word "conveniently" in this specification, and that the recommendation of the committee be adopted.

(The motion was seconded, the question was taken, and the motion was agreed to.)

\section{Mr. Holbrook (reading):}

12b. This specification reads as follows:

"12b. The clear interval between the graduations on all beams shall not be less than 0.04 inch."

Amend this specification by adding at the end thereof the following:

"-except as provided in paragraph 12c. This interval is to be measured between the adjacent edges of successive graduations representing the smallest subdivision and along the line of travel of the index of the poise. The required interval shall be main-

14 See pp. 59 and 99. 
tained whether or not the graduations are "staggered" or arranged alternately; that is, when the graduations are staggered, the interval shall be construed to be the space from one graduation to the next consecutive graduation, extended, if necessary, to intersect the line of measurement."

(The amendment was duly adopted.)

Mr. HolbRook (reading):

\section{AUTOMATIC-INDICATING SCALES}

Specifications.-2. This specification reads as follows:

"2. All weight graduations on the dial or reading face shall be clear and distinct and in no case shall their width be less than 0.008 inch nor more than the width of the clear interval between the graduations. Corresponding graduations shall be equal in width. Main graduations shall not be more than 50 percent wider than subordinate graduations."

Amend this specification to read as follows:

" 2 . Weight graduations on the dial or reading face shall be clear and distinct and in no case shall their width be less than 0.008 inch-except as yrovided in specification 3a-nor more than the width of the minimum clear interval between the graduations. Corresponding graduations shall be equal in width and main graduations shall not be more than 50 percent wider than subordinate graduations. The graduations shall be of such character and arrangement and shall be so numbered that all weight indications may be conveniently read."

Mr. HolBrook. I make the suggestion that the word "conveniently" be stricken and "accurately" inserted in view of the amendment to the previous specification.

Mr. LevitT. With that change, I move the adoption. to.)

(The motion was seconded, the question was taken, and the motion was agreed

\section{Mr. НоLвRоoк (reading):}

Add a new specification to read as follows:

"3a. Magnified Indicating Elements.-When in normal usage any indicating elements are necessarily viewed as magnified by means of a lens system, the requirements of specification 2 as to minimum width of graduations and of specification 3 as to minimum clear interval between graduations, shall be that the apparent size of the magnified image of such elements as seen by an observer occupying a normal average position with respect to the scale, shall be equivalent to the apparent size of elements complying with the stated requirements and viewed by the unaided eye from a normal distance."

The above should also appear as follows:

Under the heading "General Specifications" as 12c.

Under the heading "Computing Scales" as 9. Also change number of present 9 to 8.

Under the heading "Spring Scales" as 3a.

Under the heading "Cream-Test and Butterfat-Test Scales" as 2a.

I might make the following explanation in relation to this specification. Many years ago, perhaps in 1913 or 1914, when the original specification in relation to width of graduations and clear interval between graduations was being considered by the committee, consideration was given as to whether any change in requirement should be made in the case of scales equipped with magnifiers. At that time the magnifiers on scales were rather crude affairs. They distorted the image of the chart to the eye of the observer and it was not considered by the committee that the magnification obtained did very much good. Therefore, at that time the committee decided that the actual widths and intervals on the chart should be the governing factor regardless of whether or not the chart was magnified. As you all know, magnifiers on scales have been very materially improved since that time, some 20 years ago. On this account and with the fact in mind that the thing of importance really was the image pre- 
sented the eye of the observer, the committee reconsidered the whole specification.

Mr. Levitit. The committee did a lot of detail work on this particular item, and I think no better conclusion could have been reached by the committee. I move the adoption of the specification as read. to.)

(The motion was seconded, the question was taken, and the motion was agreed

\section{Mr. Holbrook (reading):}

Specification 8 reads as follows:

"8. When a weight indicator extends along the entire length of a graduation then all that portion of the indicator which may be brought into coincidence with the graduation shall be the same width throughout."

Amend this specification to read as follows:

"8. The relation between the widths of the indicator and the graduation with which it coincides shall be as follows: If all graduations are of equal width, the width of the index of the indicator shall be equal to the width of the graduations; if main graduations are wider than subordinate graduations, the width of the index of the indicator shall not exceed the width of the main graduations and shall not be less than the width of the subordinate graduations. When an indicator extends along the entire length of a graduation, then that portion of the indicator which may be brought into coincidence with the graduation shall be the same width throughout."

It has been pointed out by officials that on some scales the graduations are so wide and the indicators are so narrow, that there is a considerable range through which the indicator may entirely coincide with the graduation; that is, the indicator has considerable travel inside the width of the graduation itself. The proposal, we think, will result in scales which can be more accurately read.

(The specification as proposed by the committee, was duly adopted.)

\section{Mr. Holbrook (reading):}

The first portion of specification 9 reads as follows:

"9. The clearance between the index of the indicator and the dial or reading face shall not exceed 0.06 inch in the case of all automatic-indicating scales except spring scales not equipped with a device intended to compensate for changes in the elasticity of the springs due to temperature effects."

Amend this specification by adding at this point the following words:

"Or not so designed as to be substantially independent of such changes."

Mr. Holbrook. Let us say that the amendment of this specification is indicated, because springs have recently come upon the market which are designed to be independent of temperature changes. However, in relation to scales equipped with such springs, it cannot be said that there is any "device" incorporated in the scale to compensate for temperature effects because the spring itself is so designed that no such device is necessary to be attached to the scale to produce the result contemplated by this specification.

It seems obvious that whether or not the spring scale is equipped with a compensating device is unimportant. All such scales which are designed so as to be independent of temperature effects should be in the same category. The words suggested are added in order to bring this about.

(The amendment was duly adopted.)

\section{Mr. Holbrook (reading):}

Add a specification to be numbered 12 and to read as follows:

"12. On any automatic-indicating scale of a capacity of 30 pounds or less, the capacity of a bar or bars with which the scale may be equipped shall be an integral 
multiple of the capacity of the dial or reading face. Each bar shall be subdivided throughout or shall be subdivided into notched intervals each equal to the capacity of the dial or reading face, and the value of any turn-over poise provided shall be equal to the capacity of the dial or reading face."

Inasmuch as these bars and turn-over poises are provided largely for the purpose of increasing the capacity of the scale, it seems that they should increase the capacity in increments equal to the capacity of the reading face, so when a poise is advanced into a notch, or when a turn-over poise is operated, the indicator will go back to zero on the reading face, and start over again. Any other design might cause honest mistakes or facilitate the perpetration of fraud, because the customer and the user of the scale would be inclined to believe that the poises on the beam and the turn-over poises operated in the manner described, and be guided accordingly. This requirement is included in Federal Specification for Scales, Weighing, AAA-S-121a. When that specification was being prepared this requirement was circularized to manufacturers, and it seemed to be satisfactory, since no manufacturer entered any objection to the requirement.

(The specification as proposed by the committee, was duly adopted.)

Mr. HoLвRоок. The next few amendments are made on account of the following considerations.

Some years ago automatic-indicating scales were very largely of the spring type. Consequently when the committee proposed requirements for elements peculiar to automatic-indicating scales those requirements were inserted under the heading "Spring Scales." Since that time there has been a very notable increase in the number and types of automatic-indicating scales on the market, necessitating the adoption of a special code for automatic-indicating scales.

It seems to the committee that now that we have a code for automatic-indicating scales of all kinds, this code is the proper place to assemble requirements relative to dials and reading faces, indicators, methods of test, etc., and it is the proper code to which to refer the reader interested in such requirements. With that in mind we recommend the following amendments:

\section{COUNTER SCALES}

Specification 11. Amend as follows:

After the word "heading" strike out the words " "Spring scales' except that the graduations are not required to be equally spaced" and insert in lieu thereof the words, "Automatic-indicating scales".

\section{SPRING SCALES}

Specification 20 and computing scales specification 16. Amend as follows:

Change the word "heading" to "headings" and insert after the words "General Specifications" the words "and Automatic-Indicating Scales".

Strike out all specifications which are duplicated by similar specifications in the code of specifications for Automatic-Indicating Scales.

(The amendments were duly adopted).

Mr. Holbrook (reading):

The first paragraph under the heading "Tolerances" reads as follows:

"Except on the special tests described above, the tolerances to be allowed in excess or deficiency on all spring scales equipped with a device intended to compensate for changes in the elasticity of the springs due to temperature effects, shall be the values given in the appropriate column in the tolerance table under the heading 'Counter Scales'." 
Amend this paragraph by adding the following words after the words "due to temperature effects": "or so designed as to be substantially independent of such changes."

The second paragraph reads as follows:

"Except on the special tests described above, the tolerances to be allowed in excess or deficiency on all spring scales not equipped with a device intended to compensate for changes in the elasticity of the springs due to temperature effects, shall be the values shown in the following table."

Amend this paragraph by adding the following words after the words "due to temperature effects": "or not so designed as to be substantially independent of such changes."

(The amendments were duly adopted.)

\section{RESOLUTION CONFERRING AUTHORITY TO MAKE CERTAIN REVISIONS IN CODES OF SPECIFICATIONS AND TOLERANCES}

Mr. Holbrook. Mr. Chairman, I propose the following resolution:

Whereas the National Bureau of Standards may find it possible during the coming year to republish Miscellaneous Publication M85 containing all codes of specifications and tolerances of the National Conference on Weights and Measures, for the use of officials; and the codes should thus be in as good form as possible for the convenience of the officials: Therefore be it

Resolved, That the Committee on Specifications and Tolerances be given authority to reword the requirements without changing their meaning and effect, to make any desirable rearrangement and renumbering of paragraphs, and to amend cross references as to applicable codes, in the interest of brevity, good form, avoidance of unnecessary repetition, and satisfactory classification.

You have seen this morning some of the things which are necessary. All cross references should be carefully reviewed, and so forth. You will realize that we have amended our code for vehicle tanks so that we have general specifications, specifications for vehicle tanks used as measures, and specifications for vehicle tanks equipped with meters. We have amended our liquid-measuring device specifications to make them applicable to both retail and wholesale devices. In these cases it can readily be recognized that a renumbering and rearrangement of paragraphs will be necessary to get these things into shape before they are finally published as the acts of the Conference. Also, you will see the advisability of a better classification of specifications in view of the way that these codes have been built up over a very long period of years.

The resolution, I think, is worded very carefully to confer proper authority on the committee to make desirable changes in the codes without altering the effect of any requirements.

(It was moved and seconded that the resolution be adopted, the question was taken, and the motion was agreed to.)

\section{THE BYRD BILL TO CONSOLIDATE FEDERAL STANDARD- CONTAINER LEGISLATION}

By L. C. Carex, Specialist in Package Standardization, Bureau of Agricultural Economics, United States Department of Agriculture

Mr. Chairman, ladies and gentlemen, some of you may recall Mr. Spilman's discussion of "Proposed consolidation and amendment of Federal standard-container legislation" at the last national conference on weights and measures held in this city on June 3, 1931. At that time Mr. Spilman discussed in detail the provisions of a tentative draft of a bill which was in the nature of a container code, designed: First, to repeal the Apple Barrel Act which is now obsolete 
by reason of a later Standard Barrel Act and more recent apple grades; second, to centralize the administration of existing legislation pertaining to containers for fruits and vegetables by transfering the administration of the Barrel Act to the Bureau of Agricultural Economics, which now administers the two Standard Container Acts; and third, to equalize and simplify the provisions of existing laws by making the provisions of the Standard Container Act of 1916, which is an interstate commerce law, conform to those of the Standard. Barrel Act and the Standard Container Act of 1928, which are weights and measures laws.

The Byrd bill, S. 1460, and its counterpart, H. R. 8027, now pending in Congress, seek to accomplish those same ends and in addition contemplate the extension of the principle of standardization to certain types of containers not now regulated on a national basis in any way, namely, paper cartons, paper market baskets, drums, and crates and boxes.

Except in minor details and changes in the sizes of the subdivisions of the cranberry barrel, the provisions of the existing standard barrel law and those of the Standard Container Acts of 1916 and 1928 and the standards established thereunder would be reenacted under the Byrd bill. For that reason extended comment on these features is unnecessary. The cranberry barrel sizes would be the $1 / 8,1 / 4$, and $1 / 2$ barrel, instead of the $1 / 3,1 / 2$, and $3 / 4$ barrel, now provided. But it may be interesting to observe the principles upon which the standardization of cartons, crates, and boxes is contemplated.

Section 6 of the Byrd bill provides that cartons, crates, and boxes for fruits and vegetables shall be of the same units of volume and of the same capacities as those established in this act for hampers, baskets, and barrels. It should be understood that this requirement would apply only to cartons, crates, and boxes which of and by themselves are units of measure, such as the bushel box, 1/2-bushel box, and so forth. Such containers, as stated, would be required to be of the same units of volume and of the same capacities as those established in the act for hampers, baskets, and barrels. Thus the first six sections of the bill would provide standards of capacity for containers which of and by themselves are units of measure or which determine the quantity of contents sold. These are: Tills, including berry boxes; Climax baskets; hampers; round-stave baskets; splint or market baskets; drums; barrels; and certain cartons, crates, and boxes.

Another important class of containers for fruits and vegetables, chiefly cartons, crates, and boxes, is definitely and for the first time recognized in proposed national legislation. I refer to containers for fruits and vegetables, packed, marked, and sold by net weight or count. Such containers would be given legal status under section 7 of the Byrd bill. This section provides that standards for such containers may be established by the Secretary of Agriculture whenever he shall find that the standard containers established in the act are not adequate to meet the exigencies of commercial, packing, or transportation practices. Any such containers found by the Secretary of Agriculture to be reasonably necessary shall be established by him and the dimensions and capacity prescribed. Every such container shall be clearly marked with the name of the product, the net weight or count, and such further description, according to the commodity, as may be required by the Secretary. Included in this 
class of containers would be, cantaloup and asparagus crates; celery, cauliflower, cabbage, and lettuce crates; citrus boxes; peach, pear, plum, and prune boxes; apple cartons; cartons for mushrooms, tomatoes, and so forth; and others too numerous to mention.

The Byrd bill, if passed, would result in the standardization of all types of containers used for fruits and vegetables, excepting bags and sacks.

The one other section of the Byrd bill which may be of particular and peculiar interest to weights and measures officials is section 14 . In discussing the provisions of this section in $1931 \mathrm{Mr}$. Spilman said in part: "This is the section which has been devised in an attempt to make it very sure that the provisions of standard-container legislation shall not interfere with State laws or city ordinances respecting the sale of fruits and vegetables by weight. The problem was to write a section which would in no way weaken or nullify the standardcontainer legislation and which at the same time would in no way nullify or weaken what you gentlemen have accomplished in bringing about sale by weight." The problem sounds very simple, but was not found to be so, and, although the Conference was invited in 1931 to study the problem and make suggestions, no suggestions were ever made so far as I know.

However, while no constructive criticism or suggestion relating to this particular problem has been received from the various States, we have reason to believe that it may be of the utmost importance to weights and measures officials and that some provision along the lines indicated is necessary to prevent confusion and consternation in the administration of State and city regulations affecting the sale of fruits and vegetables. In at least two States the erroneous impression has apparently become wide-spread that the provisions of the Standard Container Act of 1928 abrogate all existing State laws and regulations relating to the method of selling fruits and vegetables. Nothing, of course, could be farther from the truth because the provisions of the act of 1928 apply only in transactions involving the specific types of containers which are regulated by that act, namely, hampers, round stave baskets, and splint baskets.

However, as a means of definitely protecting State and city regulations requiring sale by weight or count, the original section discussed in 1931, as it appears in the Byrd bill, has been amended with that thought in mind. This section now reads as follows:

Standard till baskets, Climax baskets, hampers, round stave baskets, drums, market baskets, cartons, crates, boxes, or barrels which do comply with the standards established under this act shall not be used by any retailer for the determination of the quantity of fruits or vegetables sold at retail unless such fruits or vegetables were received therein by him or unless such retailer is the producer or grower of the fruits or vegetables so sold. Nothing in this act shall he construed as prohibiting the sale of fruits or vegetables by net weight or numerical count.

As nearly as may be visualized by Messrs. Holbrook and Smith, of the National Bureau of Standards, and by those in our bureau connected with this work, the provisions of this section will amply protect the progress you have made in the direction of reducing retail sales to the two most accurate methods of quantity determination-weight and count.

Whether or not, or when, the Byrd bill will be enacted cannot, of course, be foretold. Strangly enough, when it was introduced in the 
previous session of Congress, there was scarcely any reaction, either for or against the measure. Similarly, when it was reintroduced in the present session, there was no reaction for or against it until it was reported favorably by the Senate Committee on Agriculture and Forestry. When that happened, opposition, more or less scattered, arose in the Western States. Much of this opposition, as it has been analyzed, is due to misunderstanding and misconstruction of the measure and misapprehension as to its effects. Generally the sentiment in the East and Middle West, as far as we have been able to observe, is favorable to the measure. While the western opposition will probably delay and possibly defeat the measure in the present Congress, it is believed that when the provisions of the bill are understood, such opposition as now obtains will largely disappear.

The Chairman. Thank you, Mr. Carey.

\section{TESTING EQUIPMENT FOR LARGE-CAPACITY SCALES}

The Chairman. We will now proceed with program item 34, "Testing Equipment for Large-Capacity Scales". Officials are invited to give particulars concerning special equipments for testing large-capacity scales. We were to have had this item last evening, when we would have had a nice discussion accompanied by slides furnished by the Philadelphia department. Unfortunately the meeting could not last a sufficient length of time to permit this. So now I would like to call on Mr. Vanderslice, of Philadelphia, to open this discussion.

PAPER OF JACOB M. VANDERSLICE, DISTRICT SUPERVISOR, BUREAU OF WEIGHTS AND MEASURES, PHILADELPHIA COUNTY, PA.

Mr. Chairman, ladies, and gentlemen, there has recently been purchased by the Philadelphia bureau of weights and measures, a "known-weight" trailer-the first of its kind in Pennsylvania-which now permits legal testing of platform scales up to 30 tons. Prior to 1934 it was impossible for the bureau to make accurate tests of platform scales of even ordinary capacity because its equipment was inadequate. With the testing weights formerly available, the best that could be done was to attempt to check heavy-duty scales with comparatively light test weights. It was recognized, however, that scales may test as accurate at 500 pounds but still be decidedly in error under heavier test loads.

In order to facilitate the legal testing of platform scales, therefore, the bureau purchased a "known-weight" trailer, adjustable up to 10 tons. The use of this device makes it possible to test platform scales from 0 up to 10 tons, including those with capacities up to 30 tons. The shifting of the trailer to various points throughout the city is made comparatively easy by the use of a motor truck capable of moving at a speed of 35 miles per hour. The appearance of this equipment is shown by the accompanying illustrations. (See figs. 8, 9, and 10.)

Ths use of a "known-weight" machine is comparatively new in weights and measures inspection. Outside of Philadelphia nowhere in Pennsylvania is it possible to make legal test of platform scales having even ordinary capacity.

In this same general connection of large-capacity scales, it may be of interest to tell you something of our activities in connection with the trafficking of coal by trucks which has confronted the staff of the 


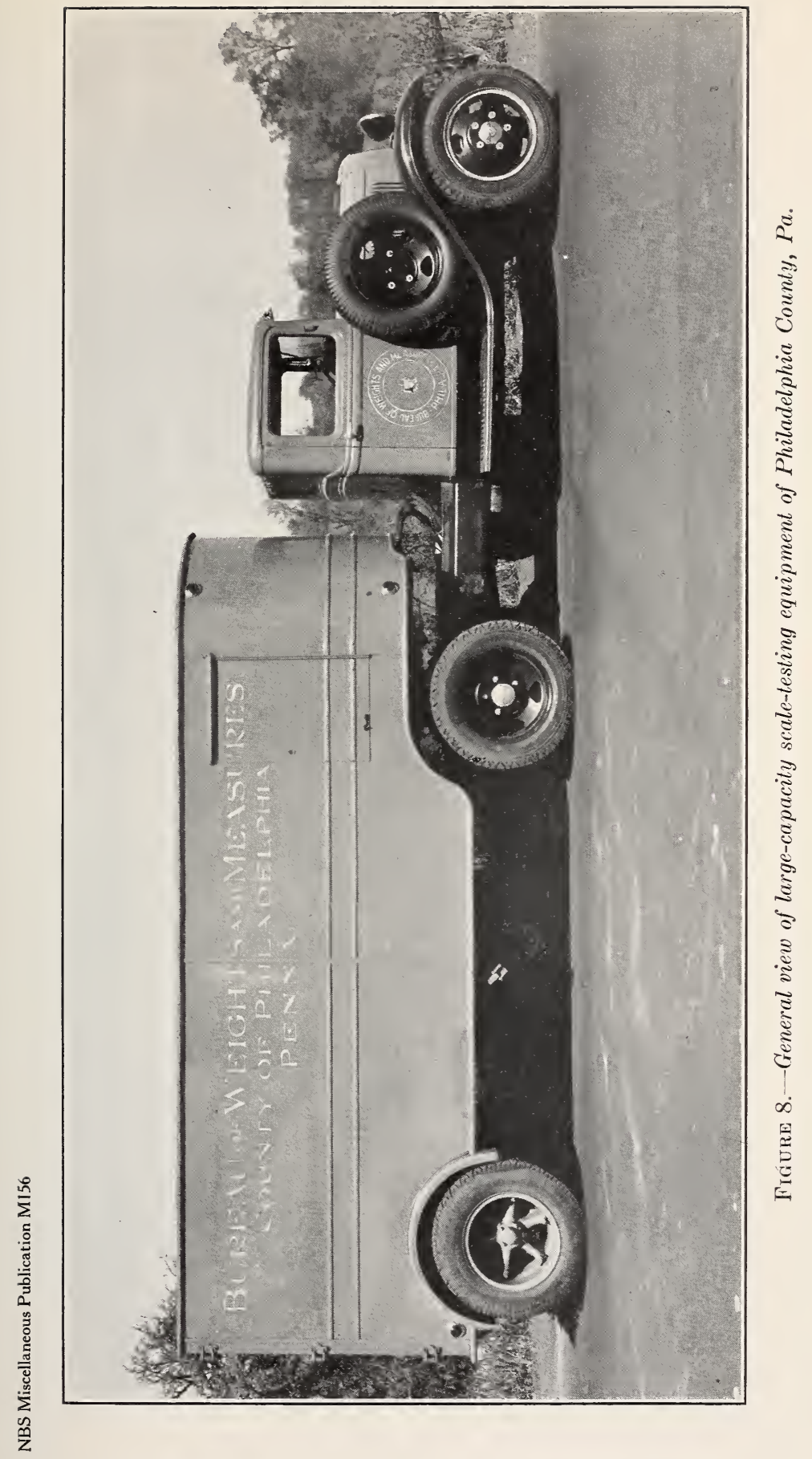


NBS Miscellaneous Publication M156

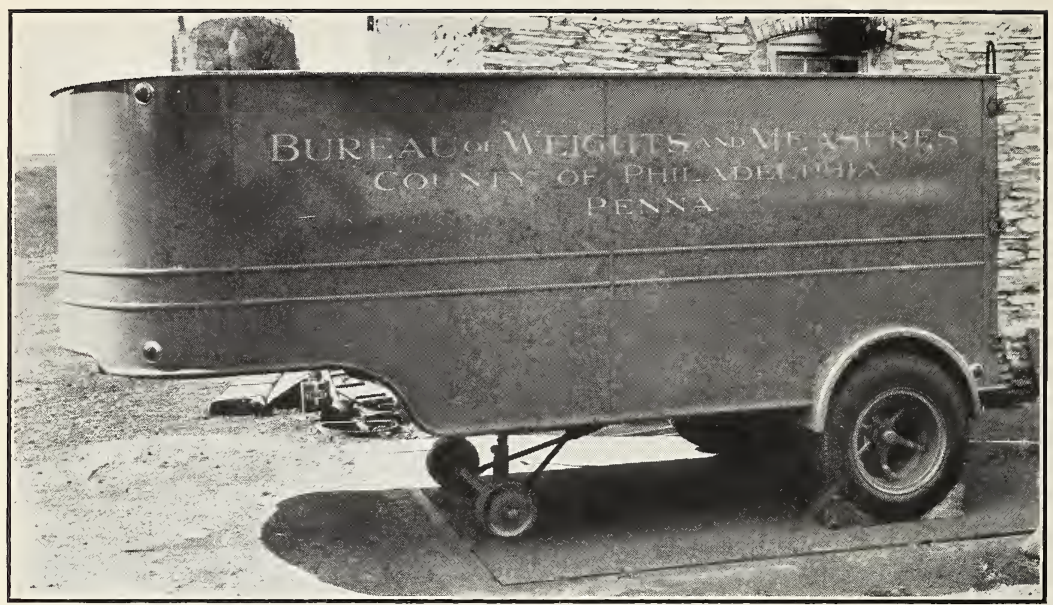

Figure 9.-Known-weight trailer portion of Philadelphia County, Pa., equipment spotted at one end of scale platform.

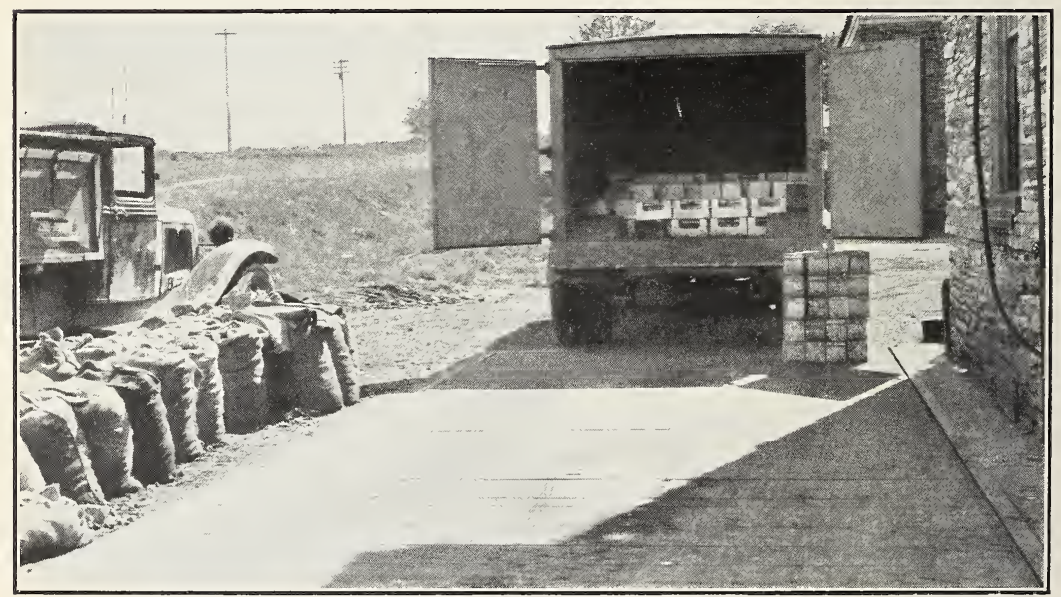

FIgURE 10.-Making corner test with 50-pound test weights. Philadelphia County, Pa., equipment. 
weights and measures bureau with a serious problem. Both the prevalence of unemployment and the cost of transportation constituted factors which have tended during the past few years to increase at a rapid rate the trucking of coal into Philadelphia from other sections of the State. While the so-called "bootleg coal" presents a many-sided problem, the only phase of the matter that need concern the bureau is whether the citizens of Philadelphia are getting the weight for which they are charged.

From records maintained by the bureau and by the NRA administrator it was estimated at one time that there were 1,747 coal trucks engaged in hauling coal of various kinds into Philadelphia. Many of these deliveries involved short-weighting the public. This practice was frequently coupled with the delivery of coal of inferior quality, so that the prices paid were frequently out of all proportion to value of the coal received.

In order to combat such short-weight practices, the bureau made a survey of trucks hauling coal into Philadelphia. Amazing discrepancies between the amounts of coal sold and the weights actually delivered were uncovered. In some instances, shortages actually exceeded the amount delivered. The minimum shortage encountered in this survey was 73 pounds per 2,000-pound ton, and the maximum shortage 1,348 pounds. In no case where the above coal deliveries were reweighed by the bureau's inspectors was it found that full weight had been delivered. Furthermore, the coal so purchased was found to have cost, on the average, slightly in excess of $\$ 13$ per ton.

While the bureau's primary function with respect to this traffic, as stated previously, is to ascertain that coal trucks are making fullweight deliveries, the scope of its work was so expanded as to make it instrumental in eliminating certain "coal rackets." The best known instance was the "Mecca case", recently publicized in the local newspapers. It relates to the apprehension and conviction of a former county emergency relief board employee actively engaged in defrauding the unemployed. It was the practice of this party to obtain advance payments on orders for coal, on many of which deliveries were never made. It is gratifying to be able to report that the bureau was instrumental in throwing light on this practice and in reporting the facts of the case to the district attorney.

It is generally recognized that the average small truck cannot carry a profitable load to Philadelphia from mines located in other sections of the State, even when it is overloaded; also that, lacking this overload, it is ruinously expensive to deliver full weight. Thus, the bureau, by merely determining that local truckers are delivering full weight, has been able to contribute effectively toward the gradual elimination of small and irresponsible trucking units.

Although coal weight inspection for this year has only been active since September 1, 1934, the following summary indicates a creditable record for this division:

Coal trucks reweighed 24,197

Violations reported.

Adjusted by Adjustment Board.

Prosecutions _...

Prosecutions discharged

As a result of these prosecutions, the city was reimbursed to the amount of $\$ 13,404$ for fines and costs. It is noted that the 
above statement fails to record the disposition of 1,465 violations, many of which were not prosecuted, these being cases (1) where informants were unable to furnish the names of violators, (2) where the bureau could not obtain cooperation from individuals cheated, or (3) where the violators forfeited their bail posted for nonappearance. In addition to these cases, there were a number of instances where the violators lived or moved out of Philadelphia. Not only does the added expense make further prosecution proceedings inadvisable, but the bureau also believes that a distinct benefit accrues to the public from dropping such prosecutions. Truckers of this type have definitely been driven out of the coal trucking business in Philadelphia, and knowing that such violation cases are pending, it is questionable whether these individuals will attempt further coal deliveries in the city.

In attempting to control the short-weight practices of various "bootleg coal" dealers, the bureau was handicapped by the lack of official scales of sufficient capacity to weigh heavily-loaded trucks. This condition was remedied, however, when city council designated 61 scales, located in various sections throughout Philadelphia as the official devices for checking the weights of coal-truck deliveries. All such scales are subject to frequent tests by the bureau's inspectors.

Under the terms of the coal-trucking ordinance passed in December 1934, all trucks bringing coal into Philadelphia must be weighed at one of the above scales. The owner of the scales on which coal is weighed receives 25 cents per load from the trucker, plus an additional fee of 5 cents for each additional consignment on such load.

Owners of scales in Philadelphia are supplied with standard coaldelivery forms prepared by the bureau. These forms are prepared in triplicate and each indicates the name and address of the dealer, the name and address of consignee, the net weight of the consignment, and the signature of the weighmaster.

The fact that a trucker has had his load weighed at one of the official scales, however, does not mean that the bureau's inspection system is at an end. A check is made on trucks by intercepting them between the weighing scales and their points of delivery, periodic checks of this sort being made in order to make sure that purchasers are receiving full weight. A tolerance of 30 pounds is allowed on each ton and the bureau is glad to be able to report that the prosecutions occurring under the present system are due chiefly to ordinance violations, rather than short-weight deliveries to customers.

Of each 25-cent fee collected by the owners of scales, 10 cents is returned to the city treasurer. The bureau estimates that an income of $\$ 25,000$ should be received from this source annually-an amount which should go far toward defraying the cost of maintaining the necessary inspection activities in this division.

As the result of thorough enforcement of the coal-trucking ordinance, the unsatisfactory conditions previously existing in the distribution of coal in Philadelphia have largely been eliminated. The coal-trucking business is being satisfactorily regulated, and the public is getting full weight on deliveries.

In contrast to the 1,747 trucks which were found to be delivering "bootleg coal" in Philadelphia during the latter part of 1934, it is estimated that there are only about 250 trucks engaged in this business at the present time. The licensing ordinance passed by city 
council on December 19, 1934, has been instrumental in this reduction. It is now required that those selling or delivering solid fuel in Philadelphia obtain licenses from the bureau of weights and measures at a cost of $\$ 75$ for each calendar year. Many irresponsible truckers have discontinued trafficking in coal rather than pay for the required licenses.

The ordinance referred to, however, failed to provide for the small hauler, who trucked from local coal yards and made deliveries to consumers on a credit basis not ordinarily obtainable from the large dealers. To meet this situation an amendment to the ordinance was passed by council on March 8, 1935. The bureau is now allowed to grant permits, costing $\$ 1$ each, to such small haulers, this being done on the theory that they are not in the coal business, make no profit on the coal, but merely obtain a small hauling fee from customers and, in many cases, extend credit on deliveries. The bureau is also legally authorized to issue additional license plates, at a charge of $\$ 1$ for each plate, to firms or individuals maintaining more than one truck.

That the city of Philadelphia is assured of a definite source of revenue from this source is shown by the following tabulation, which includes such collections made between February 15 and April 30, 1935.

Licenses, permits, and extra plaies issued, and fees collected

\begin{tabular}{|c|c|c|}
\hline Purpose & $\begin{array}{l}\text { Number } \\
\text { issued }\end{array}$ & $\begin{array}{l}\text { Fees col- } \\
\text { lected }\end{array}$ \\
\hline $\begin{array}{l}\text { Licenses. } \\
\text { Permits } \\
\text { Extra plates. }\end{array}$ & $\begin{array}{r}710 \\
73 \\
1,485\end{array}$ & $\begin{array}{r}\$ 53,250 \\
73 \\
1,485\end{array}$ \\
\hline Total & 2,268 & 54,808 \\
\hline
\end{tabular}

It is estimated that the fees collected for extra license plates will defray the cost of manufacturing all such license plates and the record cards, so that the return to the city from licenses will be free from deductions for such expenses. It is believed, moreover, that the net income derived will meet, and possibly exceed, the bureau's costs for handling this work.

The Chairman. Thank you, Mr. Vanderslice.

\section{THE TESTING OF BEER BARRELS}

By Willard E. Reed, Superintendent of Weights and Measures, Newark, N. J.

Mr. Chairman, ladies, and gentlemen, when the Government legalized beer on April 7, 1933, it caught the brewery industry and allied trades unprepared in many ways, but of most importance was the shortage of containers used for the transportation and sale of beer. Three months later, while there was an urgent need for new containers, the situation became less acute and barrels more plentiful. At the beginning, all sorts of beer kegs were put into service, many of these being old barrels that had been in service for years, or were 34678-36-9 
lying idle, and were less than the legal capacity. Steadily, during the 3 months after repeal, new barrels came upon the market, and in the course of another 6 months, new wood appeared in use in all the breweries in the State of New Jersey.

Beer is sold by the unit of 31 gallons to a barrel. This has always been the custom of the trade and is recognized by the Government, also by the State of New Jersey, for taxing purposes. By this method of measurement, the most popular container is the half barrel, or 151/2-gallon size. There are many factors which cause this package, supposed to contain $15 \frac{1}{2}$ gallons, to shrink to an actual capacity of $13 \frac{1}{2}$ gallons. First, many kegs are made of oak. To prevent leakage these are "pitched" inside before being used. Since pitch is a heavy, tarlike substance, the coating on the barrel tends to decrease the capacity. Second, since the barrels are made of wood, each time they are returned to the brewery they are inspected for leaks, and in case there is a loss from this source, they are put through a "driving" machine which forces the hoops tighter to the staves. Continued "driving," according to an authority, tends to make the barrel lose a gallon in capacity, after a year or more of use.

While this shrinkage of the wooden container is known to the trade, it is imperative to stress upon brewery owners that they should purchase beer kegs that are at least 1 quart greater in capacity than the legal requirements of $15 \frac{1}{2}$ gallons. In some instances manufacturers are making kegs of $15 \%$ gallons to allow for pitching.

Since the legalization of beer, and after a period of 13 years inactivity on the part of the trade, new developments have brought about the introduction of a metal container for the distribution of malt beverages. While there is some doubt as to the popularity of a metal container with the brewing industries, it is, no doubt, the best adapted package for holding capacities for continued use, in the eyes of weights and measures officials. Our survey revealed that there were at least 10 manufacturers who were putting out a metal container of various shapes and construction that had $15 \frac{1}{2}$ gallons capacity.

While weights and measures officials would favor a $15 \frac{1}{2}$-gallon barrel being built 1 quart oversize, it is a matter that must be taken up with the Federal and State Governments since their tax is based upon 31 gallons to the barrel. Brewery officials inform us that the Federal Government frowns upon the use of any barrel that exceeds $31,15 \frac{1}{2}$, or $73 / 4$ gallons, and that on any considerable overage, tax must be paid for the amount of another barrel of the same size. In other words, if a barrel is found to contain 16 gallons, the tax could be levied for an additional $\$ 2.50$, making $\$ 5$ in all.

On the other hand, the taxation authorities of Federal and State Governments apparently are indifferent to the use of short-sized barrels, since the tax on the short-measure $13 \frac{1}{2}$-gallon barrel is the same as on the 15/2-gallon barrel. This would tend to encourage short measurement in the distribution of beer. By the continued use of a barrel that holds $14 \frac{112}{2}$ gallons, the brewery will be paying a gallon tax on a commodity that does not exist, the purchasing public will pay for a gallon of a commodity that does not exist, and the Government will collect a tax on a gallon of a commodity that is not there. 
When it is taken into consideration that there must be thousands of barrels that are short 1 gallon in capacity, the amount of money involved is a considerable item. At this point again, we stress the suggestion that barrels be made oversize. Should a barrel start $1 / 2$ gallon oversize in capacity or, let us say, 16 gallons, for a certain period of its service, there will be an overcapacity distributed. At another point in the barrel life, the capacity will be nearly correct, and now after many months of service, the barrel will tend to give less than the quantity it is supposed to deliver. This over and under condition being distributed over a long period of time would tend to be more fair for everyone, the producer, consumer, and Government.

Everyone is familiar with the sturdy construction of the beer barrel and from its appearance a long period of service is indicated. The containers are costly and their frequent replacement because of errors in capacity that accumulate during their life, would be rather out of the question. The suggestion involving the oversize new barrel would appear, therefore, to be the most reasonable and fair to all concerned.

In our survey, 13 breweries, located at Camden, Trenton, Elizabeth, Newark, Harrison, Paterson, and Union City, were visited, and beer containers of all sizes and shapes, wood and metal, were tested to capacity. Since this survey additional breweries are now operating, making a total of 18 , along with 185 bottling plants.

Barrels made in Europe, and imported from Germany, Great Britain, Switzerland, France, Holland, and Belgium were inspected and tested. While barrels from Poland, Ireland, and Austria were not found in New Jersey breweries, it is known that there are containers, manufactured in these countries, in use in the State.

There are three ways of testing the capacity of a beer barrel.

Probably the simplest, and one that will permit the weights and measures officials to test more barrels, is by the use of the gauge rod and the United States Gaugers' Manual. By this test, the mean diameter of the barrel is determined by subtracting the head diameter from the bung diameter; this difference is then multiplied by 0.63 and the product added to the head diameter, which gives us the mean diameter. The mean diameter is then squared and multiplied by 0.0034 , which result is then multiplied by the length of the barrel to obtain the capacity. Inside dimensions are taken in every instance.

The second and more accurate test is known as the volume test. This requires one-half hour to complete. The barrel is filled with water. The spigot is inserted in the bung top and the water is run off into liquid measures. By this test, the capacity of a barrel may be determined down to fluid ounces, as all barrels are sold with liquid content. The test is conducted under the same conditions as exist when the barrel is used.

The third method, which is known as the weight test, was not originally tried, although the department has since made use of this method at times. This test is based upon the weight of water contained in the barrel. Thus, a 151/2-gallon keg should contain 128 pounds and 10 ounces of water, on the basis of 8.3 pounds per gallon. Due to varying weights of beer, a test by weighing a keg filled with beer was not used, nor is it suggested to be used. Water is a more constant factor.

It seems reasonable to assume that the quantity of beer in a barrel or keg should be determined on the basis of its volume at the tempera- 
ture at which it is barreled and dispensed; this temperature is believed to average about $41^{\circ} \mathrm{F}$. At this temperature the average weight per gallon of beer is probably close to 8.46 pounds, although individual beers may differ from this by as much as 1 percent either way.

Containers suspected of containing less than the proper amount of beer (on the basis of 31 gallons to the barrel) may be weighed and marked for identification before being tapped; after having been emptied they may again be weighed and their original contents in gallons arrived at by utilizing the figure above for the average weight per gallon. This result should be fairly accurate. For more precise determination, the weight per gallon of the particular beer in question could be individually determined and used instead of the average value.

With particular reference to quantity determination the Federal authorities have adopted more modern methods, namely, the use of meters, whereby the tax is determined on the basis of what the meters actually show in gallons.

There was a further angle to the container situation that was not generally understood by the manufacturers of beer barrels, and that is, there is a law in New Jersey that requires the maker of any weighing or measuring device to submit to the State department of weights and measures for approval such equipment as is intended for use here in the determination of quantity.

Beer containers come within the scope of this law, and we require that each manufacturer shall submit samples of his barrels to the State superintendent of weights and measures for inspection and test before their distribution in this State is attempted. We have contacted all manufacturers coming under our notice and have advised them of our requirements should they have occasion to sell their barrels to brewers in our State. Some have already submitted their containers and received approval, others are following. Without State approval beer containers will have no legal standing. The law that governs this serves a very worthy purpose and will tend to prevent shortmeasure barrels from getting into use. We enforce this law to the letter. Brewers have been advised to demand of salesmen or manufacturers a certificate of approval írom our department before making purchases of beer containers.

Inquiry has been made as to whether it is necessary to place a label bearing a statement of the quantity of the contents upon kegs and barrels containing beer, ale, or porter, in view of the fact that the revenue stamp upon such kegs and barrels states the quantity.

The Federal Food and Drugs Act, as amended, requires marking with a plain and conspicuous statement of the quantity of the contents and the regulations (F. I. D. 154) require all statements of the quantity of liquids to be in terms of the United States gallon and its usual subdivisions. In the opinion of the bureau the statement of quantity placed upon the revenue stamp is not a marking sufficient to comply with these requirements.

In conjunction with this law the State superintendent has also set up certain tolerances and regulations covering beer barrels. All beer barrels or kegs shall be marked, stamped, or branded in a permanent manner with the name and location of the brewer or brewers using such barrels or kegs.

State authorities and brewers differ somewhat on tolerances to be allowed in excess or deficiency in all barrels or kegs used for the distribution of beer, ale, or porter. 
The tolerances to be allowed in excess and in deficiency in all barrels or kegs used for the distribution of malt beverages shall be the values given in the following table; provided, however, that the manufacturers' tolerances for new barrels or kegs shall be one-half of the values given. The word "manufacturers" as used in this section shall apply to the makers of such barrels or kegs.

WOODEN BARRELS AND KEGS

\begin{tabular}{|c|c|c|}
\hline \multirow{2}{*}{ Capacity } & \multicolumn{2}{|c|}{ Tolerance } \\
\hline & In excess & In deficiency \\
\hline $\begin{array}{l}\text { Barrel (31 gal) } \\
\text { Half barrel (151/2 gal) } \\
\text { Quarter barrel (73/4 gal) } \\
\text { Eighth barrel (37/8 gal) }\end{array}$ & 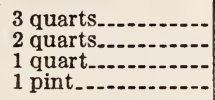 & $\begin{array}{l}1 \text { quart. } \\
1 \text { pint. } \\
1 / 2 \text { pint. } \\
1 \text { gill. }\end{array}$ \\
\hline
\end{tabular}

STEEL BARRELS

Barrel (31 gal)
Half barrel (151/2 gal)
Quarter barrel (73/8 gal)
Eighth barrel (37/8 gal)

In view of this difference regarding tolerances on beer containers, our State superintendent, Mr. Berg, has been in conference with the brewers in New Jersey in order that the brewers and weights and measures officials may arrive at a definite decision regarding a fair tolerance.

I might say, at this time, that our reception at the various breweries visited was cordial and every facility for testing was placed at our command, even to the extent of interrupting the routine of their work.

The Chairman. Thank you, Mr. Reed.

\section{DISCUSSION OF ABOVE PAPER}

Mr. Fitzpatrick. I am not a member of the Conference, but after Mr. Reed's talk, I wonder if I might call attention to a matter which came to me when I was assistant administrator of the Brewers' Code Authority of the United States.

One thing that we are a little bit fearful of is the excess proposed to be allowed by the excellent paper you have just heard. At the present time I merely wish to call your attention to the fact that no Federal ruling of the alcoholic tax unit of the Bureau of Internal Revenue has as yet been made.

There is a 31-gallon barrel required for tax purposes, and then there is a $31 \frac{1 / 1}{2}$-gallon barrel specified by some State laws. I call to your attention that the contents of this container is not definitely decided on and there is very, very considerable difficulty in getting a standard. Individual standards set up by the various departments will not solve the matter. The departments in the various States should cooperate to find whether a barrel is going to be 31 or $31 \frac{1}{2}$ gallons in size. Then the Bureau of Standards should be consulted so as to get a definite measure. Everybody from the producer to the consumer is interested to have a barrel of liquid contain 
a certain standard capacity and to get the proper amount distributed.

I wish to recommend to you gentlemen that it might be well for you to consider this matter very carefully.

Mr. Emhardt. In regard to Mr. Reed's paper, and the conditions we have in Philadelphia, I wish to point out from a practical standpoint that this question of beer is quite a sore spot in Philadelphia. We have a new measuring device made by one of our companies, and we have discussed this matter with Mr. Reed, and have gotten some very fine information from him.

The beer barrels that are being supplied Philadelphia by the brewers are running about 5 gallons short. There are considerable shortages in the half barrels and the quarter barrels, also. So we are in a very bad situation today, as you can see. We get some of our beers from outside of Philadelphia-from Allentown and Reading, as well as other places. We try to enforce our regulations strictly at the present time.

I might say that I don't know just what apparatus the brewers in Philadelphia use for testing the capacity of containers. I know that old kegs are common and it is entirely right for them to use them, but we find them short, too. We have yet to find any of the kegs that are very short, in beer from outside of Philadelphia. Perhaps the practical thing for the men here to do is to remove the beer to see that the proper amount of beer is in the container.

Mr. WaLdman. I am particularly interested in this beer-barreltesting proposition, because of a case I had a year or more ago. I had received numerous complaints that the retailers weren't getting the amount, or the number of glasses, out of a barrel advertised in a pamphlet issued by a brewery in St. Louis, so I decided to make a few tests on their barrels. I did not have an experience like Mr. Reed. On the contrary, I met with a great deal of opposition. I wasn't permitted on the premises until I threatened arrest. Now that is a fact.

After I got in the plant I was confronted with another situation. The brewers' union threatened to pull every man out of the plant if I touched a barrel. I had to overcome that situation before I got results. Then I began to make tests, and I found they had twothird barrels which were short in excess of tolerances. I think the same condition prevails in most of the breweries. I think this barrel question needs some real worthy study:

Mr. Stiles. There are one or two points that do not seem to me to be entirely clear. You speak of barrels coming from the manufacturers, but it is not a finished product when it comes from the manufacturer, is it? I believe a barrel should be a uniform product. Of course, they have to drive the hoops on to keep them tight, but the practice should be such that delivery can come from the brewery in full amount. It is highly essential that a tolerance in excess be allowed on these barrels if you are going to have full capacity when the breweries actually fill them.

There is another problem in practically all the States. The law provided for $31 \frac{11}{2}$ gallons for a barrel. It is difficult to set up a tolerance in accordance with the law, and have it apply on all liquids, when actually your beer barrel contains only 31 gallons. I don't know how you are going to overcome this difficulty in most States. In our State we changed the law to provide that the beer barrel should 
have a capacity of 31 gallons, primarily to make it conform to the Federal tax law, which apparently set up this standard in opposition to all State laws as to the capacity of barrels. I do hope that if we arrive at 31-gallon standard, we will make a reasonable tolerance, actually enforcible and operative in the same manner as for other containers.

Mr. REED. Some time ago taverns in New Jersey commenced to advertise the 16-ounce glass of beer. Only those in the community, or the neighborhood in which this tavern was located, knew there was a 16-ounce glass sold, due to the fact that the advertising did not come to the attention of the stranger. In the event the customer doesn't ask for a 16-ounce glass, he will not get it. It is a sort of "come-on" as we call it up in Jersey. We haven't found any real difficulty, but they do not really give it to every customer that comes in there; as I said, those living in the neighborhood know of it; others coming in will get a smaller glass, 8 ounces or even 6 ounces. In our investigations that is what we have found.

Now in regard to sham glasses, there is where we actually found shortages, and this is what we do. We go to these taverns and purchase two glasses and bring them out to make the test. If they do not hold the required capacity, the seller is in trouble. But, after all you nearly always find 6-ounce and the 8-ounce glasses all right. In any event the man who is dispensing the beer is not actually at fault because he bought the glasses in good faith.

\section{THE WEIGHTS AND MEASURES PROVISIONS OF THE COPELAND} BILL TO REVISE THE FEDERAL FOOD AND DRUGS ACT

By W. S. Frisbie, Chief, Division of State Cooperation, Food and Drug Administration, United States Department of Agriculture

Mr. Chairman and gentlemen, the title of this paper is to a slight degree misleading since the Copeland bill which passed the Senate on May 28 contains, strictly speaking, no provisions referring to weights and measures as such, nor does it standardize any food or drug or cosmetic in terms of weight or measure. Associated with weights and measures laws, however, are those provisions which require a declaration of the quantity of contents in the case of food in package form. That section in the Copeland bill which refers to the quantity of contents is, with one exception, the same as the proviso in the present law which was passed in 1906. The exception to which I refer is the word "accurate." In other words, the bill declares a food to be misbranded if it is in package form and fails to bear a label containing an accurate statement of the quantity of contents in terms of weight, measure, or numerical count. A proviso is added permitting reasonable variations and exemptions as to small packages, these variations and exemptions to be prescribed in regulations by the Secretary of Agriculture. At the present time, certain variations are recognized by regulations of a general, rather than a specific, character. In other words, no specific tolerance is set up for the various articles of food. The exemptions are more specific in that one-half avoirdupois ounce, or less, of food is considered small and no net weight statement required. A package containing 1 fluid ounce or less of food is small and similarly exempted from net weight labeling. It is obviously inopportune to undertake any forecast as to the 
nature of regulations to be adopted if and when this measure becomes a law, although it is important to note that the bill as at present drawn authorizes the Secretary of Agriculture, as soon as the bill is passed, to conduct hearings and formulate regulations which shall become effective on and after the date when the law goes into effect. It is worthy to note that the injunctions regarding the declaration of quantity of contents are applicable under the terms of this bill to drugs and to cosmetics which are in package form. At the present time, of course, there is no Federal act regulating the composition or labeling of cosmetics and in the case of drugs net weight statements. are not required.

Another section of the Copeland bill declares an article of food to be misbranded if its container is so made or filled as to mislead the purchaser. This, of course, is the essence of the so-called "slack-fill" bill which has appeared in one form or another before Congress for a number of years, the first one having been introduced by Mr. Haugen, who was chairman of the House Committee on Agriculture, on September 2, 1919. This bill passed the House in December 1920, and was referred to the Senate Committee on Agriculture and Forestry, but did not pass the Senate. In subsequent sessions of Congress, similar bills were introduced by $\mathrm{Mr}$. Haugen, the last having been introduced in the first session of the Seventy-second Congress. Some of these bills passed the House, but in no instance both the House and the Senate. At the Seventy-third session of Congress, the slackfill and deceptive container provision was incorporated in the bill S. 1944, frequently referred to as the Tugwell bill, amending the Federal Food and Drugs Act. The intent of the provision is obvious since the purchaser naturally regards the size of the package as an index of its contents. It has been contended frequently by those opposed to such legislation that the purchaser has ample information with an accurate statement of the quantity of contents, but this is not necessarily so, since the great variation in density of solid foods affords the average purchaser but little conception as to the meaning of a quarter ounce, half ounce or an ounce in terms of bulk. This is particularly true in the case of spices which were conspicuous examples of slack-filling at the time of the World War and immediately following. That the practice has not entirely been abandoned is evidenced by the collection of samples in the year 1935 .

So far as interstate commerce is concerned, the enforcement of this proviso does not represent entirely a virgin field of endeavor for there has been for 4 years a slack-fill requirement in the act by virtue of the McNary-Mapes amendment, so far as canned fruits and vegetables. are concerned. The authority conferred on the Secretary of Agriculture by this amendment is extended in the Copeland bill in the section which authorizes the establishment by the Department of definitions and standards for food. This section of the bill authorizes the Secretary to promulgate regulations fixing not only a definition and standard of identity but a reasonable standard of quality, including the fill of container. Exempted from the standard of quality, however, are fresh fruits and fresh vegetables. A proviso in this section directs. the Secretary to give due consideration to the natural shrinkage in storage and in transit of fresh, natural food and to the necessity for suitable packing and protective material. Progress, of course, has already been made under the existing amendment. As you are 
probably aware, standards for some fruits and vegetables, including fill of container, have been adopted.

State legislation, however, has preceded Federal, so far as slack-fill food is concerned, since at least three of our Commonwealths have on their statute books provisions of this sort.

It appears that Nebraska was the first State to legislate on the subject of slack-fill of package food. An amendment to the food law which has been in force for nearly 15 years declares food in package form to be misbranded regardless of any statement as to quantity of contents if the package itself is not filled with the food it purports to contain. This was followed shortly by legislation in North Dakota and in Alabama, both of which adopted a similar amendment to the existing food law. In none of these States, however, is there any injunction regarding the use of deceptive containers. Accurate figures are not available as to the extent to which the practice of slack-filling has been corrected by the adoption of these amendments. So far as any corrective effect from a Nation-wide standpoint, this appears to be negligible, but this is not surprising in view of the magnitude of the commerce in food, both interstate and intrastate, exclusive of these three States, entirely without regulation so far as interstate shipments and intrastate sales are concerned. State officials are to be commended, however, for their aggressiveness in undertaking to correct this practice so far as their individual laws are concerned. A conspicuous example is afforded by the recent activities in Alabama. The department of agriculture and industries, which enforces the Alabama food law, has recently collected a number of samples of food products which show a degree of slack-filling for which apparently no valid reason can be offered on the basis of commercial practice. For example, six samples of black pepper showed a fill of container from 82 percent to as low as 43 percent, coffee and chicory compound 67 to 80 percent, the average about 70 percent, and one sample of tea revealed a 53 percent fill of container. A package of fancy sealed pecans in an attractive basket with a false bottom bearing the net weight label on the bottom of the package was only 77 percent filled. It may be contended by the manufacturers that space must be allowed in a carton of salt to permit easy removal of the contents, but it would seem that 28 percent of head space would be more than ample for this purpose. Three samples of salt collected showed a fill of 72,75 , and 80 percent, respectively. Slack-filling appears even to have invaded the field of drugs for Alabama reports epsom salt in package form with a 66 percent fill of container. Regardless of the claim of the manufacturer or packer that he is giving his customers their money's worth in all instances, slack-fill packages are inherently deceptive and should be forbidden both by State and Federal laws.

To the members of this conference a deceptive container is a familiar figure. The fancy candy box which apparently would hold a pound or a pound and a half actually, but contains 14 ounces, the bottle with a gigantic dimple in the bottom, and other devices, are too well known to need any extended comment. It is a matter of history that the various slack-fill bills considered by Congress were opposed, particularly with regard to the deceptive-container provision, by the manufacturers of glass bottles. They stated their apprehension that such legislation would eliminate the heavy shouldered bottle which 
they deemed essential for shipments to avoid unnecessary breakage. No law, whether State of Federal, can be enforced if it is unreasonable, impractical, or in any way capricious in its terms. The language of the Copeland bill refers to containers of food which are made or formed in a manner to mislead the purchaser. An extract bottle with heavy shoulders to withstand breakage need not in addition be made with a thick bottom, deep panels, and elongated neck; no one can truthfully assert that such a bottle is not deceptively formed. There are many other examples of deceptive containers as evidenced by recent purchases made by the food and drug administration. Here, again, the argument may be advanced that if the quantity of contents are accurately stated there is no cheat on the consumer; this may be true but at least he is deceived and disappointed and should not be forced to give critical examination to casual or everyday purchases in order to avoid deception. Sponsors of the Copeland bill believe that the incorporation of this particular provision will be decidedly in the interest of the consumer without being oppressive to the manufacturer of food containers.

The Chairman. Thank you, Mr. Frisbie.

\section{THE ANNUAL ASSAY COMMISSION}

\section{By H. W. Bearce, National Bureau of Standards}

Mr. Chairman, members of the Conference, ladies, and gentlemen, the Annual Assay Commission meets at the United States Mint in Philadelphia on the second Wednesday in February of each year to examine and test the fineness and weight of the gold and silver coins reserved by the several mints for that purpose from the coins minted during the preceding calendar year.

In order that you may have in mind certain of the important basic facts relating to our coinage, and particularly those relating to the functions and procedure of the Annual Assay Commission, I shall refer to or quote from the laws and regulations relating thereto, and from the rules adopted by the Assay Commission in 1930. The section references are to the United States Code, title 31, chapter 8.

Section 315 sets out the denominations and weights of gold coins in detail, but I presume that these provisions have been repealed by the steps taken to revalue and nationalize gold, referred to later in this paper.

Sec. 316. Silver Coins; Weight.-The silver coins of the United States shall be a dollar; a half-dollar, or fifty-cent piece; a quarter-dollar, or twenty-five-cent piece; and a dime, or ten-cent piece. The weight of the dollar shall be fourhundred and twelve and one-half grains troy of standard silver, the weight of the half-dollar shall be one hundred and ninety-two and nine-tenths grains; the quarter-dollar and the dimes shall be, respectively, one-half and one-fifth of the weight of said half-dollar.

Sec. 349. Deviations Allowed in Adjusting Weights; Silver Coins.-In adjusting the weight of the silver coins the following deviations shall not be exceeded in any single piece: In the dollar, the half and quarter dollar, and in the dime, one and one-half grains.

In order to indicate the accuracy formerly required to be obtained in the weight of gold coins, I will also quote section 348 relating to this subject although it is, naturally, of no practical consequence at this time since gold coins are no longer being minted. 
Sec. 348. Deviations Allowed in Adjusting Weights; Gold Coins.--In adjusting the weights of the gold coins, the following deviations shall not be exceeded in any single piece: In the double-eagle and the eagle, one-half of a grain; in the half-eagle and the quarter-eagle, one-fourth of a grain. And in weighing a number of pieces together, when delivered by the superintendent of coining department to the superintendent, and by the superintendent to the depositor, the deviation from the standard weight shall not exceed one-hundredth of an ounce in $\$ 5,000$ in double-eagles, eagles, half-eagles, or quarter-eagles.

By the terms of sections 321 and 346, standards for fineness of gold and silver coins are set up.

Sec. 352. Sealing and Transmitting Trial Pieces.-At every delivery of coins made by the superintendent of coining department to a superintendent, it shall be the duty of such superintendent, in the presence of the assayer, to take indiscriminately a certain number of pieces of each variety for the annual trial of coins, the number for gold coins being not less than one piece for each 1,000 pieces or any fractional part of 1,000 pieces delivered; and for silver coins one piece for each 2,000 pieces or any fractional part of 2,000 pieces delivered. The pieces so taken shall be carefully sealed up in an envelope, properly labeled, stating the date of the delivery, the number and denomination of the pieces inclosed, and the amount of the delivery from which they were taken. These sealed parcels containing the reserved pieces shall be deposited in a pyx, designated for the purpose at each mint, which shall be kept under the joint care of the superintendent and assayer, and be so secured that neither can have access to its contents without the presence of the other, and the reserved pieces in their sealed envelopes from the coinage of each mint shall be transmitted quarterly to the mint at Philadelphia. ***

Sec. 363. Assay Commissioners.-To secure a due conformity in the gold and silver coins to their respective standards of fineness and weight, the judge of the District Court for the Eastern District of Pennsylvania, the Comptroller of the Currency, the assayer of the assay office at New York, and such other persons as the President shall, from time to time, designate, shall meet as assay commissioners, at the mint in Philadelphia, to examine and test, in the presence of the Director of the Mint, the fineness and weight of the coins reserved by the several mints for this purpose, on the second Wednesday in February, annually, * * * If it appears by such examination and test that these coins do not differ from the standard fineness and weight by a greater quantity than is allowed by law, the trial shall be considered and reported as satisfactory. If, however, any greater deviation from the legal standard or weight appears, this fact shall be certified to the President; and if, on a view of the circumstances of the case, he shall so decide, the officers implicated in the error shall be thenceforward disqualified from holding their respective offices.

\section{RULES ADOPTED BY ASSAY COMMISSION IN 1930 FOR ORGANIZATION AND GOVERNMENT OF THE COMMISSION}

The first five rules have to do with the formal organization of the Commission, and the delivery of the reserved coins to them.

VI.- The chairman will then arrange the members of the board in three committees-one to take charge of counting, one of the weighing, and the other of the assaying, with power to associate members interchangeably and to require the manipulatory aid of the officers of the mint.

VII. Of the Counting.- The committee on counting shall receive from the superintendent of the mint at Philadelphia the packages containing the pieces reserved by the several mints for the trial of coins in accordance with section 3539 of the Revised Statutes. These packages shall be compared by the committee with the transcripts furnished with them and shall be properly verified. The committee shall select packages from each mint for each month's coinage and containing all denominations coined, and accurately count the coins therein. The committee on counting shall deliver to the committee on assaying and to the committee on weighing such of the reserved coins as those committees may choose for their examination.

VIII. Of the Assaying.-(a) The committee on assaying shall receive the several parcels of reserved coins from the committee on counting.

(b) They shall select parcels representing each month's coinage of each mint and containing all denominations coined; from each of the parcels chosen they 
shall remove therefrom such a number of coins of the different denominations as will in their best judgment be sufficient for individual test assays.

(c) From such other parcels as they may judge to be sufficient for the purpose they shall remove one or more coins to be melted together and cast into an ingot of convenient size, from which samples shall be taken for test assays. * * *

IX. Of the Weighing.-(a) The committee on weighing shall receive from the committee on assaying the residues of the several parcels of reserved coins, and shall take at random from the parcels of each mint such a number of coins of each of the denominations represented and so distributed by dates of coinage as will in its best judgment be sufficient for the purposes of weighing.

(b) The pieces taken shall be severally weighed by the committee on weighing or under the scrutiny thereof, and their respective weights ascertained to an accuracy of not less than 0.01 grain and the results shall be noted with a special reference as to any that may be found without the legal limits of weight.

(c) The committee shall examine the standard weights employed in the mint and shall satisfy itself that they are satisfactory as to accuracy in accordance with the standards prescribed by law in section 3549 of the Revised Statutes.

$\mathrm{X}$.- The weighings and assayings having been completed under the scrutiny of the committees, respectively, the committees will report, fully and specifically, as to the coins of each mint.

XI.-And thereupon the commissioners will proceed to declare their judgment by an open vote; and a full record thereof, and of all their doings, having been engrossed by the secretary, it will be signed by all the members and delivered to the Director of the Mint, after which the board will be adjourned sine die.

The foregoing rules are subject to such modifications or alterations as a majority of the board may at any time during each annual assay deem expedient and proper.

\section{ADOPTED BY THE ASSAY COMMISSION OF 1898}

The committee (on weighing) recommends that the standard weights which are kept specifically for the use of the Assay Commission, and which are retained in possession of the Director of the Mint, be sent in December of each year by him to the Director of the Bureau of Standards, who shall have them compared with the legal standard and who shall forward them each year, under seal, to the commission with a certification of their accuracy.

Some years ago it was customary for the President to appoint a rather liberal number of persons to the Assay Commission, a small number of whom performed the active duties of the Commission. In recent years the number has been so reduced that practically every member must take an active part in the work of one of the three committees.

One member of the Commission is usually appointed from the staff of the National Bureau of Standards, and it has become the custom for this member to serve as chairman of the committee on weighing.

The members of the Commission assemble at the Philadelphia Mint at about 10 o'clock on the morning of the second Wednesday in February. They are greeted by the Director of the Mint, the superintendent, and other officials, and shortly thereafter the Commission meets and organizes for carrying out its work. The Commission elects a chairman and secretary, and the chairman of the Commission then appoints a chairman for each of the three committees, (1) On counting, (2) or assaying, and (3) on weighing, and assigns the remaining members to the several committees as seems most appropriate. The chairman of each committee is usually an expert in the work to be performed by his committee.

After the Commission has been organized, as above outlined, a recess is usually taken and the Commission conducted through the mint on a tour of inspection after which luncheon is served. Immediately after luncheon the Commission reassembles, by committees, and begins the active work of counting, weighing, and assaying the 
coins selected from those reserved for that purpose, representative samples being taken from each shipment.

The actual work of the committees usually occupies the afternoon of the first day, and either the morning or morning and afternoon of the second day, the time required depending upon the effectiveness of the committees and the number of coins to be examined.

It may be thought that the work of the Annual Assay Commission is perfunctory, a mere matter of form. Such, however, is by no means the case. Each committee does its work with extreme care and thoroughness, and when each mint gets a clean bill of health, as they usually do, it may be taken as good evidence that the coinage for the preceding year has actually been held within the limits of weight and fineness provided by law.

The seriousness of the situation, should any coins be found to be outside the legal limits of weight or fineness, can be seen by reference to section 363 quoted above. I know of only one instance in which serious errors were found. In that case the officer responsible was actually disqualified and removed from office.

In view of the number and value of the coins minted each year by each of the several mints the record of accuracy is remarkable and greatly to the credit of the organization-the Director of the Mint, the superintendents of the several mints, and all who participate in this important work.

The annual report of the Director of the Mint is a most interesting and informative document. From this we can learn not only the value and number of coins minted during any year, but also the total value and number of coins of all kinds and all denominations since the beginning of our coinage in 1793 .

For example, we learn from this publication that $\$ 50$ gold pieces were minted only in 1915 ; that double eagles, or $\$ 20$ gold pieces, were minted in every year except 1917, 1918, and 1919, from 1850 to 1932 ; that eagles, or $\$ 10$ gold pieces, were minted from 1793 to 1804 , and from 1838 to 1933 , with a few exceptions between 1917 and 1931; that half eagles, or $\$ 5$ gold pieces, were minted in every year except 1816 and 1817 from 1793 to 1916 , and since 1916 only in 1929 and 1933 ; that $\$ 3$ gold pieces were coined only between 1854 and 1889 ; that quarter eagles or $\$ 2.50$ gold pieces were coined between 1796 and 1929 , with several years missing; that standard gold dollars were coined every year from 1849 to 1889 ; and that since 1889 the only gold dollars coined have been special memorial or commemorative coins minted in 1902, 1903, 1904, 1905, 1915, 1916, 1917, and 1922.

Similar detailed information is given for silver coins and for the various minor coins of nickel, copper, and bronze. You may learn, for example, that in 1922 there were minted no 5-cent pieces, and fewer bronze 1-cent pieces than in any other year since 1878. This information may not be important to you unless you happen to be a collector of coins. It would, however, indicate, for example, that a half-cent piece minted in 1831, a 1-cent piece minted in 1877 , or a 2-cent piece minted in 1878 would, because of its relative scarcity, probably be worth more than its face value.

Information as to the number and value of the coins turned out by all the mints over a period of several years may be of interest. In the 10-year period ending with 1933 , the total number of pieces was $2,131,323,124$, having a value of $\$ 1,086,490,433.50$. 
The Assay Commission does not test the minor coins, i. e., 5-cent and 1-cent pieces, nor does it test the coins minted for foreign countries, of which during the year ended June 30, 1934, there were 10,540,000 silver pieces and 8,500,000 nickel pieces, or a total of 19,040,000 pieces coined for foreign countries. These were all coined at the Philadelphia Mint and were for Colombia, Cuba, Ecuador, and Honduras.

Since January 31, 1934, there has, of course, been no gold coined in the United States. It seems probable, however, that you still have an interest in the theoretical gold dollar and the relation it bears to the former standard of value. I shall therefore mention it briefly.

The following is quoted from the report of the Director of the Mint for the year 1934, under the heading "Gold Revaluation and Nationalization."

Supplementing the President's order of April 20, 1933, prohibiting gold hoarding and establishing Government control of the export of gold, an Executive order was issued under date of August 29, 1933, providing that gold produced from domestic mines might be sold abroad at world market prices. Under this order the United States mints and assay offices received, on consignment, the newly produced gold, supported by affidavits evidencing eligibility, and delivered gold for sale. The average sale price under this order was $\$ 30.99+$ per fine ounce, as compared with the price theretofore in effect of $\$ 20.67+$ per fine ounce, the coining value of an ounce of pure gold.

Executive order of October 25 authorized acquisition by the Reconstruction Finance Corporation of newly mined domestic gold received on consignment by United States mints and assay offices. Gold was received under this order at the official prices fixed from day to day, ranging upward from $\$ 31.36$ to $\$ 34.06$, averaging to January 15, 1934, approximately $\$ 33.58$ per fine ounce. Executive order of January 15,1934, and regulations issued thereunder authorized purchase by the New York Federal Reserve bank of gold received on consignment by the mints and assay offices, at prices fixed from day to day by the Secretary of the Treasury. Under this order the price was fixed at $\$ 34.45$ per fine ounce, and remained thereat until the President formally revalued the United States gold dollar by proclamation of January 31, 1934, under the act of May 12, 1933, as amended by the Gold Reserve Act of 1934. This proclamation declared the gold dollar to be $15 \%$ grains of gold nine-tenths fine, which is equivalent to $\$ 35$ per fine ounce. Thereafter the United States mints and assay offices resumed the purchase of proffered eligible gold, at the price of $\$ 35$ per fine ounce.

On this basis the new dollar is theoretically worth 59.06 cents in terms of the old dollar, or the old dollar is worth about $\$ 1.69$ in terms of the new. That, of course, does not necessarily mean that it now takes $\$ 1.69$ to buy what $\$ 1$ would buy before the revaluation.

The nature and arrangement of the report of the Annual Assay Commission can best be shown by the use of excerpts from an actual report. For that purpose I shall make use of the report of 1931, covering the calendar year 1930 . The following material is quoted from that report, special attention being given to the report of the weighing since that is the phase which, I think, will be of the greatest interest.

The work of the committees having been completed at 11:20 a. m., the Commission was called to order by the presiding officer, and the reports of the various committees as submitted by their respective chairmen were accepted as satisfactory.

\section{COMMITTEE ON ASSAYING}

The committee on assaying has completed the test assays on individual coins and mass melts representing the different denominations coined by the mints at San Francisco and Philadelphia, no gold or silver having been coined during the year at the mint in Denver. 
No half eagles were made during the year, and the only gold coinage was executed at the mint in San Francisco.

According to the following table, showing the extreme variations found on individual coins and mass melts tested under the supervision of the committee, the 1930 coinage of the several mints has been found safely within the legal allowance prescribed by law, which is one one-thousandth fineness for gold and three one-thousandths for silver coins.

Highest assays on gold coins: San Francisco

Lowest assays on gold coins: San Francisco _

Highest assays on silver coins:

Philadelphia

San Francisco

Lowest assays on silver coins:

Philadelphia_._. 698.6

San Francisco

Mass melts:

San Francisco (gold)

Philadelphia (silver)

San Francisco (silver)

\section{COMMITTEE ON WEIGHING}

The committee on weighing reports that in accordance with the rules adopted by the Assay Commission in 1930 the committee received from the committee on assaying the residues of the several parcels of reserved coins, and took therefrom at random from the parcels of each mint such a number of coins of each of the denominations represented and so distributed by dates of coinage as to be sufficient for the purposes of weighing. It was found possible to select one or more coins from substantially every one of the 103 parcels presented. The above procedure resulted in the selection of 295 pieces.

Each of these coins was weighed to an accuracy of 0.01 grain and the results recorded. The standards used were a set of sealed coin weights and a set of grain weights, delivered to the Commission from the Bureau of Standards, Washington, D. C., under seal and accompanied by certificates signed by the Director of the Bureau. The weighings were made by the method of substitution on the balance belonging to the Philadelphia Mint regularly employed for this purpose. This balance was tested before the weighing of the coins was commenced and was found to be accurate and reliable and very well adapted for the work of the committee.

The weight of each coin is given in the table below. An examination of these results will demonstrate that each coin was well within the deviation allowed by law. Also the average weights of the coins of the several denominations were very close to the standards similarly established.

The deviations from standard of the heaviest and lightest coins encountered, of each denomination from each mint, are shown in the following table:

\begin{tabular}{|c|c|c|c|c|c|c|c|}
\hline \multirow{2}{*}{ Coins } & \multirow{2}{*}{$\begin{array}{l}\text { Legal } \\
\text { devia- } \\
\text { tion } \\
\text { allowed }\end{array}$} & \multicolumn{2}{|c|}{ Philadelphia } & \multicolumn{2}{|c|}{ San Francisco } & \multicolumn{2}{|c|}{ Denver } \\
\hline & & Heavy & Light & Heavy & Light & Heavy & Light \\
\hline $\begin{array}{l}\text { Gold: } \\
\text { Double eagle............. }\end{array}$ & $\begin{array}{r}\text { Grains } \\
0.5\end{array}$ & Grains & Grains & $\begin{array}{r}\text { Grains } \\
0.15\end{array}$ & $\begin{array}{c}\text { Grains } \\
0.02\end{array}$ & Grains & Grains \\
\hline $\begin{array}{l}\text { Eagle-- } \\
\text { Silver: } \\
\text { Quarter dollar. } \\
\text { Dime. }\end{array}$ & $\begin{array}{l}1.5 \\
1.5\end{array}$ & $\begin{array}{r}1.15 \\
.44\end{array}$ & $\begin{array}{r}1.11 \\
.48\end{array}$ & $\begin{array}{r}.30 \\
1.09 \\
.53\end{array}$ & $\begin{array}{r}.21 \\
1.03 \\
.85\end{array}$ & & $\ldots$ \\
\hline
\end{tabular}

After the weighing of the coins reported above, your committee tested the weight known as the "Troy pound of the mint", a weight of great importance not only because it is the primary standard of the Philadelphia Mint, but also because of its long and interesting history. The standard used in comparison was a Troy pound weight known $2 \mathrm{~s}$ "B. S. Troy pound 63 " furnished by the Bureau of Standards for this purpose and accompanied by a certificate giving its correction. Several observations were made both by reversing the weigbts on the pans of the balance and by substitution. Unfortunately the balance upon which 
the weighing was necessarily conducted was not very well adapted to a test such as this. It was a balance of relatively large capacity and consequently not a very sensitive one; neither did it repeat its indications with precision. Therefore the value of the weight under test could not be obtained with the precision which the committee would have desired to attain. The error of the weight was so small as to be less than the probable error of the final result. It can be confidently said, however, that the weight is correct within an accuracy of +0.02 grain.

In connection with the above comparison combinations of weights of the set used as working standards of the Philadelphia Mint were tested and it was indicated that these were of satisfactory accuracy.

Upon the completion of the reading and acceptance of the committee reports, Mr. Shields suggested that the thanks of the Commission be extended to the mint officials and employees for their courtesy and assistance during the sessions of the Commission, and also to the chairman for his very able direction of the work, all of which met with the hearty approval of the members.

(Signed)

Walter T. TAGGart, Chairman,

O. B. Dickinson,

A. R. Johnston,

William S. WALKER,

William A. Ashbrook,

F. S. HоLBROOK,

B. G. SHIELDS,

Thomas A. Wright.

On completion of the work of the Commission, it is customary for each member to be presented with a commemorative bronze medal. I have here an example of such a medal, which I am sure you will be interested in examining. It is that of the late President Coolidge. The latest medal (1935) is in honor of President Roosevelt. In each case the medal is in honor of the President who is in office at the time of meeting of the Commission.

The Chairman. Thank you, Mr. Bearce.

\section{REPORT OF COMMITTEE ON NOMINATIONS, AND ELECTION OF OFFICERS}

The Chairman. Is the committee on nominations ready to report? Mr. HolвRоок. The report has been laid on my desk.

The Chairman. The report will be read by the secretary of the Conference, instead of by the committee.

Mr. Holbrook (reading):

Your committee on nominations presents the following list of names for officers and members of the executive committee for the ensuing term-

Officers: Lyman J. Briggs, president; John P. McBride, first vice president; C. D. Baucom, second vice president; Martin L. Lang, third vice president; J. C. Tinkey, fourth vice president; F. S. Holbrook, secretary; George F. Austin, Jr., treasurer.

Members of the executive committee: Seth L. Lightfoot, Howard E. Crawford, S. H. Wilson, John J. Levitt, Rollin E. Meek, S. T. Griffith, George S. Barnard, Louis G. Waldman, Walter G. White, John S. Burke, C. J. Reynolds, C. R. McFadden, Urban E. Dice, B. W. Ragland, H. N. Davis, and George Warner.

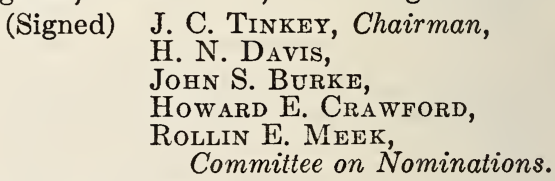

Mr. HolbRook. In view of the nomination of Mr. McBride, I will assume the chair for a moment. Are there any further nominations?

(It was moved and seconded that the nominations be closed, and that the secretary be directed to cast the ballot of the Conference for the officers and mem- 
bers of the executive committee, as nominated, the question was taken, and the motion was agreed to.)

(Accordingly, the secretary cast the ballot of the Conference for the officers and members of the executive committee, as nominated by the committee on nominations, and they were declared duly elected.)

(Mr. McBride resumed the chair.)

The Chairman. You very deeply honored me when you selected me as temporary presiding officer of the 1935 Conference. I was a little nonplussed when my name was presented as first vice president and in doubt as to whether I should continue. I am also a member of the committee on specifications and tolerances, and I do not intend to be a "secretary of everything." I think probably I have acted properly in standing for nomination as vice president, as it will allow me to continue for the ensuing year. Incidentally since I arrived, it is the first position I have received that has any indication of a point of rest. And that is the hope in the position. I thank you very much.

I think, gentlemen, that I will take advantage of being a vice president, and will ask Mr. Baucom to assume the chair.

(At this point, Mr. Baucom assumed the chair.)

THE CONTROL OF “BOOTLEG” COAL

By S. T. Griffith, Chief, Division of Weights and Measures, Baltimore, Md.

Mr. Chairman, and ladies and gentlemen, probably one of the most unusual developments during the economic depression, particularly to departments of weights and measures in the Middle Atlantic States adjacent to or near the anthracite coal region, and especially to the coal industry in general, is a new method of mining and disposing of coal, which, for want of a better name, has been termed "bootlegging coal." This name is not quite the proper one to apply, because, as we generally understand the term "bootleg" it connotes the dealing in an unlawful product, and coal, we know, is not an unlawful commodity. However, the method of handling this product is so closely allied to the term that it is commonly used throughout the trade, for in most instances the coal is illegally mined or "taken" and disposed of in a manner not altogether in accord with existing laws; hence, the term, "bootleg" coal.

Let us consider this subject from three different angles, which when taken together will, perhaps, present a fairly comprehensive recapitulation of the most important factors: First, the mining or the obtaining of the coal, and the distribution and transportation of same; second, the method of disposing of the coal, and the effect upon the business of retailing coal; and third, the methods employed by departments of weights and measures and other Government agencies to control the proper delivery of accurate weight of the coal, and observance of existing coal laws.

In the first instance, we find that the source of nearly all of this bootleg coal is in the Pennsylvania anthracite coal region, comprising that territory extending approximately from Susquehanna County and Lackawanna County in the northeast to Dauphin County and Lebanon County in the southwest, an area of between 500 and 600 square miles. 
Ever since anyone in the Pennsylvania mining regions can remember, miners and their families have been in the habit of going to the culm dumps surrounding their homes to pick coal from among the rock and slate thrown out by the big collieries in the cleaning process. Practically all of the coal companies permitted this, and the "pickings", as a rule, were used for fuel in the miners' homes. Sometimes it was used to pay church dues or a grocery bill, but no one ever sold the coal for cash.

In the last decade the equipment installed and used by the big collieries has become so efficient that many of the miners were deprived of work, and not only that, but little, if any, coal was thrown upon the culm dumps. This, you can see, produced a most interesting socio-economic condition. In a little while, miners began to dig for coal in nearby hills, usually at night and in the woods, to conceal their activities, in places where coal was known to be near the surface. Some then began to sell coal to their neighbors for cash or in exchange for food and merchandise.

Some town and county welfare boards have even met relief requests for fuel by suggesting that the nearby hills were full of coal. This resulted in complaints by some of the coal companies who caused arrests in a number of instances. The welfare board, however promptly secured the release of the bootleggers if it could be proven they had dug the coal for personal use. In most cases, the word of the bootlegger was all that was necessary to satisfy members of the welfare board, usually neighbors, and for reasons of their own, more or less antagonistic to the coal companies.

The local courts also were not inclined to punish these bootleggers. Further, the collieries were apprized that any drastic action preventing or hampering the jobless miners from digging in these holes would probably result in higher taxes in order to provide for more relief.

From a recent article in "The Nation" it is learned that only in a few places-Shamokin in Northumberland County for one-are the bootleggers tapping big veins of coal which the coal companies would eventually mine themselves.

In 1931 and 1932 this bootleg coal hardly ever was sold beyond a dozen miles from the place where the bootleggers had dug it, and probably amounted to not more than three or four hundred thousand tons in all. Today, the article mentioned states, there are about 5,000 holes or tiny coal mines that are bootleg operated every day in the week, except Sunday, occupying the time of more than 15,000 men and boys. Between four and five thousand trucks, with two and sometimes three men on each, are transporting this coal to consumers in the Middle Atlantic States daily.

From apparently reliable reports gathered from Government agencies and civic organizations, it is safe to estimate that approximately 100,000 men, women and children are now directly dependent for a living on bootleg coal. In 1934, so great had the "bootleg" coal business grown that there were illegally mined and "taken" from the anthracite coal region from four to five million tons of coal, amounting in money value to from $\$ 35,000,000$ to $\$ 40,000,000$. This brings bootleg coal into the class of big business; only no one engaged in it makes big money. It has been stated that these bootleggers and truckers do not make more than $\$ 2.50$ average per day. The millions of dollars encompassed in this bootleg industry is spread out very 
thin, and is distributed in the mining regions to the stores, restaurants, movies, drinking places, gas stations, banks, etc. You can readily see, therefore, that almost everyone in the territory affected is naturally very much in favor of bootleg coal.

In most cases the coal companies and collieries do not object so much to the coal being "stolen" as to the same being transported and sold so successfully throughout the Middle Atlantic States, New York, New Jersey, Pennsylvania, Maryland, Delaware, in Washington, D. C., and in Virginia and West Virginia.

Public sentiment, however, is against the collieries and they can do little about it at the source. They have tried it. In Northumberland County last December, one of the largest coal companies endeavored to begin operations in an area where several thousand unemployed miners were ekeing out an existence. The bootleggers immediately blew up the steam shovel, and up to the present no arrests have been made. Private policemen employed by the Philadelphia \& Reading Coal \& Iron Co., dynamited over a thousand holes in a few months, but in that time, so "The Nation" says, at least 4,000 new ones were started on the same properties.

During the same period, the same company caused the arrests of nearly 100 bootleggers, but without avail. No jury in any anthracite county is apparently willing to convict anyone for "taking" or trucking coal. The Governor of the State has been requested to take action, but refused, telling the coal companies the men must have work. In the past few months, groups of bootleggers in a few instances have been making terms with the collieries, mostly to independent mine owners, and are beginning to pay a small royalty on every ton of coal they take. Few radicals are found among the bootleggers, who are generally anticommunists, and this perhaps accounts for the lack of serious outbreaks throughout the anthracite coal regions.

Not only the unemployed miners are now engaged in this traffic, but owners of trucks from nearby States are hooked up with them just to do the hauling. It is estimated that not more than half the trucks engaged in transporting coal carry Pennsylvania tags.

The second point involves the method of disposing of "bootleg" coal, and the effect upon the business of retailing coal-and in this connection, may I refer to the conditions in Baltimore City, with which I am personally familiar.

Sometime in 1933 there began to appear on the streets of Baltimore in the outskirts of the city, automobile trucks of 5-ton capacity, loaded with anthracite coal of various sizes transported from Pennsylvania, and which our inspectors of weights and measures reported were being delivered direct to the residences of purchasers. No doubt this condition also prevailed in other cities and towns within hauling distance from the coal mines, usually within 150 miles.

Upon inquiry, it was found that the householder claimed to have purchased direct from the mines the entire truckload of coal, and little attention was therefore paid to the delivery of same by the department of weights and measures. Soon thereafter, however, in the fall of 1933 and the beginning of 1934, these bootleg coal trucks became much more numerous until finally, as far as we could ascertain, as many as 400 truckloads of coal were being disposed of per week. 
It is reported by the Baltimore Coal Exchange from their invest1gations that over a quarter million net tons of bootleg coal were disposed of in the city during 1934. This coal was at first peddled or sold direct by the trucker to the consumer, but now this method has been augmented by itinerant "coal brokers"-persons acting as agents for the truckers. Regular trips from the mining region have now been established by the bootlegger, so that when the truck arrives in Baltimore, deliveries are made on orders already secured. In every instance the sale of this coal is for spot cash, whereas the local coal merchant usually extends credit.

These so-called "coal brokers" usually have no place of business, but operated from their home. This coal is offered at a price much less than that possible by the established coal dealer, and averages from 75 cents to $\$ 1$ over and above the f. o. b. mine price. Such competition is fast annihilating the local coal merchant, who, with his investment-yards, etc.-and taxes to Federal, State, and local governments, together with freight rates and salaries, cannot stay in business at the prices offered by the bootlegger, who has nothing practically at stake, is not entirely responsible, pays no taxes to anyone, except perhaps for the license tag on the truck, and is without facilities for accurate-weight delivery.

This same condition must be affecting in like manner the business of established coal dealers in every community reached by the trucks of the bootleggers. These established coal merchants are fighting with their backs to the wall, struggling for their commercial lives, and with no real hope of adequate relief in sight. The railroads and transportation companies have also contributed to the complexity of the problem. Freight rates are comparatively the same as they were 10 years ago, and much more costly than trucking direct to the consumer's door. These transportation interests, although losing heavily each year in freight revenue, have practically stood on the side lines "holding their hands." Only this last month have they taken any action by putting in a reduced freight rate good until October, and this offers only partial relief.

For the past 2 years, it has been conservatively estimated that between 5 and 10 percent of all anthracite coal sold in the United States has been bootleg, and the price has been from 25 to 50 percent less than that charged by established or regular coal merchants. This is not only serious, but ruinous, competition.

The third point involves the methods employed by departments of weights and measures and other Government agencies in the control of "bootleg" coal, the proper delivery of accurate weight, and observance of existing coal laws.

Departments of weights and measures have been overwhelmed with the problem of meeting the growth of this new business, and even today ways and means of supervising and controlling the distribution of bootleg coal has not been entirely and satisfactorily solved. One reason for this is the factor of interstate commerce and, according to several adjudicated cases, highest courts have held that local laws cannot be enacted in restraint of this phase of trade.

Probably the best laws so far enacted and being prepared are found in the Commonwealth of Pennsylvania, where the movement of bootleg coal is strictly intrastate. There they have enacted and are about to pass laws which will enable the department of weights 
and measures to more thoroughly control the handling of bootleg coal. Competent weighmasters are licensed for a fee of $\$ 5$ covering a period of not more than 3 years, and every truckload of coal must be weighed on scales selected and approved by the weighmaster, who then furnishes official delivery tickets made out as prescribed by the statute. This applies to all deliveries of more than 100 pounds, but does not apply to boat or carload lots. The act is very comprehensive and should afford due protection for the citizens who purchase this coal.

In order to further the better control of the disposition of coal by truckers, Pennsylvania has also introduced, if they have not already passed, an act requiring the registration with their public service commission, of all trucks engaged in the hauling of coal, and no truck will be allowed to operate without a permit granted by this commission. Other States, too, have similar statutes affecting coal, but the problem is to enforce equally and impartially with the "bootlegger" and the regular coal merchants.

In Baltimore two ordinances were introduced in the city council looking to this control, both of which, however, were withdrawn when declared by the city solicitor to be in violation and a restriction upon interstate commerce. This left the solution of the problem to the department of weights and measures, with nothing other than the statutes requiring full weight and measure upon the sale and delivery of commodities, and covering the sizes of specified legal measures. A very unsatisfactory handling of the coal-trading situation has ensued.

With the small force of inspectors of weights and measures already fully occupied with regular weights and measures inspection work, it was necessary to ask the aid of the police department, and several plain-clothes officers and an automobile were assigned to this work. All together some progress was made, which, though not entirely satisfactory, was very encouraging. Deliveries of bootleg coal were checked and weighed on sealed scales approximate to the point of delivery, and many convictions were secured for short weight, as the bootleggers were endeavoring to determine the amount of a ton of coal by using bushel fruit baskets. This very unreliable method practically left them guessing as to the accuracy of the delivery intended.

In other States, New Jersey as one example, the authority of appointing honorary superintendents of weights and measures has been invoked with some success. As mentioned before, these truckers sell this coal considerably cheaper than local dealers. Consumers who buy from them save money, and courts and juries frequently look to the main question in cases of this kind rather than to the statutory charge upon which a defendant is being tried, and the main question is whether or not he is intentionally and deliberately cheating the public. It must be admitted that the bootlegger saves money for the consumers. We have, therefore, learned not to expect to get very far in the prosecution of these cases.

Our local courts are inclined to be very lenient in cases involving first offenses. We can report, however, that over $\$ 5,000$ has been collected in fines for short weight and the possession and use of measures of illegal size, the peak number of convictions being 47 in one week during August 1934. The fines ranged from $\$ 2.45$ to not more than $\$ 100$ in each case. 
It is understood that nearly all of the departments of weights and measures in the several States in which the distribution of bootleg coal is being made, are making better progress in the control of this unusual business.

It would appear that this bootleg-coal problem is here to stay for some time. Independent mine owners are now getting into the picture. Having been denied or unable to establish affiliations with the large coal companies and being thus prevented from securing railroad facilities, they are turning to the truckers.

Whether the improvement of general business conditions and the return to their usual employment will eliminate the bootlegger and trucker remains to be seen. The problem of the control of "bootleg" coal is with us and must be satisfactorily met. Certainly no one is in favor of driving anyone out of business, and sides cannot be taken by any department of weights and measures with either the bootlegger or the established coal dealer. We must and will accomplish control by impartially performing our duties as sealers or inspectors of weights and measures, but insisting that the same laws and equitable conditions be met by both.

The Acting Chatrman. Thank you, Mr. Griffith.

\section{SIDE BEAMS, HIDDEN WEIGHTS, AND DIAL SCALES}

\section{By J. C. Tinkey, Deputy State Sealer, State of Ohio}

Mr. Chairman, ladies, and gentlemen of the Conference, by invitation of the National Conference a paper was prepared by the writer upon the subject "Side-Beam and Hidden-Weight Scales", which was read on June 6, 1930. Perhaps some in this audience have read it in the Conference report.

From 1912 to 1923 , while a county sealer in Ohio, I was many times amused and chagrined to see the customers in a busy store "crane" their necks, trying to see the weight of the purchase that they were about to part with some of their hard-earned money in buying. We resolved, then and there, that sometime there should be a correction made, so that the purchasers could see, and readily see, the amount they were buying, but we realized that not much could be done about it in one county alone. After the transfer to State work there were so many things to be done, especially in cleaning up the gasoline-pump situation, that the opportunity to take action in this matter did not present itself until the year 1929 .

We discovered sufficient law and specifications to back us up in demanding a change of construction and installation, and on September 20,1929, a circular letter was mailed to all pump, oil, scale, grocery companies, and sealers, calling their attention to certain laws and specifications. This brought forth the interest anticipated and on September 10,1930, circular letter 6 was issued and has been the means of bringing wonderful results. No doubt many of you have read this circular as it has been widely distributed. It has answered its purpose, but in time, we have found that it could be improved upon, just like everything else can be, and have made a few necessary changes.

Hon. Earl H. Hanefeld, director of agriculture and State sealer, of Ohio, and Mr. W. D. Leech, chief of the division of foods and dairies, by whom the weights and measures work is supervised, in the revision 
of this particular circular 6 , which will hereafter be known as regulation 11, saw the wisdom of having this important matter controlled by special regulation, and the wording as now adopted in our book 11, we believe, will meet every purpose for which it is intended and make its enforcement more efficient.

Some of the defects to be corrected are the use of scales that are not properly constructed, installed, or marked with the capacity, and with dials, pointers, side beams or added weights that are not in plain view of the customer, and therefore, in violation of section 7965-1, general specifications 2 and 24, and counter-scale specifications 8 and 10 . All new scales shall comply with these specifications and with the following regulation:

(1) All counter and computing scales shall be set upon a solid foundation. Suspension scales shall be hung from a strong permanent support. The reading of all scales used to weigh in the presence of the customer shall be within 3 feet of the customer, or so placed that the weighing element can be easily and accurately read from the natural position of the customer. Suspension or counter scales, with dials, shall have two dials and be glass covered, except when scale is permanently placed where only one side can be read, then one dial is sufficient.

(2) Old scales used for weighing in the presence of the customer, that have hidden "side beams", "poises", or "weights" shall be placed in a clear, readable position to the weigher and the customer, or securely fasten or remove from use, the "poise" or "weight." Scales setting or hanging crosswise of the counter are not permitted, unless on the end of the counter, and then only if the weigher and customer can easily and accurately read the indication of the scale.

(3) Have the dealers place their scales in such a position that the purchaser can see the indications on the scale. View with suspicion any scale which is so placed that the purchaser cannot see the indications of the weighing, also view with suspicion any scale which has the weights continually kept upon it or where heavy paper is placed upon the scale pan.

Circular 6 was mailed to scale manufacturers, dealers and sealers, also to sealers of other States and cities, and I will quote a few excerpts taken from the replies of 3 scale companies, 6 State officials, and 2 city sealers, which will give you the average trend of thought of some 40 or 50 replies received.

1. We do not state 3 feet, but I think it is a good idea. The customer should easily read the computing scale, or in fact any type of scale, and if the hanging type, it should not be hung too high or too low; it should be hung in line with the customer's eye. We in a general way carry out your circular 6 .

2 . In our opinion, it would be a good thing for the general public if the inatters that you mention were put into effect and carried out, because it is necessary that every safeguard possible be given to the general public and to put forth effort to establish these rules. It is unlikely that they would be adopted by this State unless they were adopted and approved by the National Bureau of Standards, and in such case, this State would adopt them automatically. We would be glad to join you in an effort to have them adopted.

3. I think I can safely state that we can support the Ohio Department in all essentials of its regulation governing this type of scale. We shall give your circular further consideration and perhaps will make some recommendations on this subject to our State conference which will meet in September.

4. There are a number of cases where scales are used in a temporary location, for instance, in the sale of fruits and vegetables or on sale days, and it seems to me that there would be considerable difficulty encountered in enforcing the provision requiring that the scale be set upon a solid counter. It seems to me further, that the term "solid counter" is rather indefinite. Suppose that the counter itself is solid but the floor that the counter rests upon is unstable. Would not that cause the same condition as an unstable counter? Your phrase "should have two dials and be glass covered": there are cases where the scale is suspended against the wall or with its back near the wall where the dealer and customer usually occupy about the same position and there would be no object in that case of changing the position of the seale nor would it-accomplish anything for 
the customer by having two dials on the scale in that position. We, clearly, under the law of this State, have the authority to make regulations regarding the construction of the scales themselves, but it is doubtful if we can regulate the placing of the scales in certain specified positions in the stores.

5. We took action last year to cover this matter and have found it to work out very well-a penalty of $\$ 25$ for the violation of this ruling. You are not alone in taking action along this line and the move you have taken is certainly one in the right direction. I feel that other States will see the wisdom of adopting regulations of a similar nature, regardless of whether or not the National Conference take any action or make any recommendation in the matter.

6 . We have always required just the items proposed in your circular and that scales be so placed that the customer is able to read the dial the same as the dealer. I assure you that I am in hearty accord with the proposal and it should be adopted by the National Conference.

7. I have read with much interest your circular 6 and we agree entirely with your requirements 1 and 2 . These have been adopted here and we find that both the store owner and the customer are more satisfied. In regards to your item 3, requiring 2 dials and be glass covered, I wish to say, not in the nature of criticism, that this department does not intend to ever make such a ruling, because there are no reasons for it. Suspension scales are not allowed to be hung up with a wire, rope, or chain. An arm, at the end of which is a hook, is permanently. attached to the wall or to the display shelves. The scale is so placed at the end of the arm that the dial does not move sufficiently to hinder the reading by the store owner or the customer.

8. It is contemplated by this office to enforce such regulations within the next year and we are glad to see Ohio taking this step also. It is regretted that further discussion was not had at the recent National Conference when the subject was brought up, but due to the lateness of the appearance on the program, no doubt it will be given further consideration by each individual sealer in his own jurisdiction, and finally culminate in definite regulations at the next Conference. It is the opinion of the writer that your proposed regulation will be a step forward in the improvement in the use of this type of weighing device, and result in mutual benefit to both the merchant and the customer.

9. We have always believed that regulations of this kind would serve the public and manufacturer better if issued by the National Conference, but it seems no action was taken on your recommendations. We have always thought, and do now, that the sealers of weights and measures in all States prepare the necessary regulations for the protection of the purchaser, and in so doing we have always found the regulations to be fair, and have met them by making our product to meet their requirements. We think the manufacturer should have no part in preparing any of the plans or regulations that are used by the sealer's departments. Every manufacturer today is endeavoring to perfect a weighing device and many recommendations of benefit to the manufacturers have come from the sealers throughout the country. We believe we should not offer any suggestions to you or attempt in any way to help regulate the procedures of the sealers of weights and measures. When such regulations are promulgated, it is our duty to provide machines that will meet such requirements, and we hope to do so in every case.

10. We are disposed to support cordially and earnestly all State regulations which require instruments of the most accurate construction reasonably possible for weighing and measuring. It will be our pleasure to comply with the proposed new circular 6 , although frankly we do not recognize the necessity of the requirement in suspension scales of double dials or of glass-covered dials. Nevertheless, we have always manufactured scales complying with these requirements, so are in position to supply them.

11. Personally, I think any law should either be enforced to the letter or repealed and your department's idea of taking this matter up at this time is most commendable. I believe and hope that all of the scales we manufacture now conform to this law, however, I am enclosing a circular and will greatly appreciate it if you will let me have your advice regarding this and your comments should our present construction be in any way objectionable. Again assuring you that we are very anxious to cooperate in the good you are doing and anticipating your further comments with much interest.

We have not found it difficult to enforce the regulation. The scale companies were instructed as to what was required, both as to the new and old equipment, and agreed to cooperate with the sealers of Ohio, who were also properly instructed through our sealers' meetings held 
at various places and through them the dealers were informed of the requirements. Occasionally a scale salesman in his eagerness to make a sale would sell a package-weighing scale for counter use, without informing the dealer as to its limits, only to find out later, when the sealer refused to seal the scale, that he had created a condition which was embarrassing to all parties concerned and reflected back on the scale company, and which could have been avoided had regulation 1 been complied with. This reads as follows: "When the manufacturers place with the dealers only those devices which comply with the State specifications, and dealers use only those that are allowed in the manner designated, and replace obsolete equipment as soon as possible with equipment that does comply, conditions would be much better and everyone more nearly satisfied. The sealers receive their instructions from the State sealer, and are, we believe, fair to all and willing to do everything in their power to render service. We desire your cooperation in the adjustment of those matters to the end that the sealer, dealer, and consumer may each have a square deal."

In attempting the enforcement of any new regulation, or, as in this case, enforcing an old one, there are always a few people who stretch their imagination and at once begin to criticize and spread the news; saying, "There they go again, going to condemn and destroy all of our old equipment and compel us to buy new" and get themselves all "het up" over the matter even before they know what it is all about. I have often wondered about it. You never have to even hint that a person should have a new automobile, he just has to have it to be in style and keep ahead of his neighbors and have something "good" and right up to date. How I wish this were the policy in weighing and measuring devices.

You will particularly notice in this regulation that we did not have in mind the entire elimination of this type of scale. To change a longestablished custom and eliminate weighing and measuring devices, when in proper order to do correct weighing and measuring, is not the right thing to do; for very often the fault is not in the device itself but rather in the method of operation and its use or misuse, as, for example, a scale could be within 3 feet of the customer and meet every specification and still be entirely hidden from his view, by having piles of merchandise between the scale and the customer. This is one of our "worries" today and a constant source of annoyance, and the question is "Just what can be done about it?" Our mind is open about these matters, and we would certainly like to hear from others.

The quickest and best method of stopping the practice of piling goods in front of the scales is to educate the customers (if such a thing is possible) to exercise their rights by demanding that they be permitted to at least have the opportunity of seeing the weighing. Section 7965-1 empowers us to condemn weights and measures when found to be false or fraudulent, and we contend that when a device is not in the view of the customer it can be so used. Specification 24 states that a weighing or measuring device shall be so constructed as not to facilitate the perpetration of fraud; and, again, a hidden beam or weight can be so used. Specification 8 states that the setting of invisible weights shall be plainly indicated on the customer's side of the scale, and we understand that a beam is a weight.

The above specifications are good, but not quite sufficient to entirely handle the matter, and some States do not have a law similar to our 
section 7965-1. With our specification 11, first paragraph, added to the above, we have a workable regulation. We recommend that this Conference adopt specifications and regulations such as Ohio has adopted.

(While Mr. Tinkey was speaking, Mr. McBride resumed the chair.)

The Chairman. Thank you, Mr. Tinkey.

\section{DISCUSSION OF ABOVE PAPER}

Mr. Bortell. Must a scale have a double dial if it is placed permanently against the wall?

Mr. Tinkey. Not if it is permanently against the wall.

Mr. Bortell. Suppose about 3 months later it be moved to a new position.

Mr. Tinkey. That is where the burden is on the sealer, for when he finds it has been moved from its former place, then, of course, it may come under condemnation proceedings.

\section{UNDERCOVER BUYING AS AN AID TO LAW ENFORCEMENT}

By George M. Roberts, Superintendent of Weights, Measures, and Markets, District of Columbia

Mr. Chairman, ladies, and gentlemen, I fear that sometimes, we, as weights and measures officials, devote too much attention to regulation of mechanical devices, and too little attention to regulation of human devices.

The head of a weights and measures department who allows the work of his department to be confined to testing weighing and measuring instruments falls far short of performing his duty to the public.

Methods of merchandising have advanced to such a state of sophistication that those who desire to defraud the public no longer resort to the expedient of manipulating their scales, measures, gasoline pumps, or other instruments. The old-time methods of manipulation of instruments have been eliminated to a very large extent at least. The machinations now resorted to frequently represent a high degree of efficiency resembling schemes planned by so-called "efficiency engineers.". Some such schemes, when finally uncovered, are amazing in their simplicity.

The meat dealer no longer weighs his hand. One of the tricks now used by meat dealers is to place the commodity on the scale, remove it quickly, and announce the total price in excess of what it should be. The customer usually accepts his statement, pays his money, and happily goes on his way unconscious of the fact that he has been swindled. The motorist drives into a filling station, orders the quantity of gasoline he desires to buy, looks at the hand on the dial of the pump, sees that it points to the figure representing the number of gallons he has ordered, and pays his money, wholly unconscious of the fact that the pump operator may have started his pump on one gallon, or resorted to some other deceptive means to deliver a gallon short measure.

Another method used in some instances, where goods are put up in packages, is to reduce the weight of each package slightly below the quantity represented. While each customer may be defrauded to a very small extent, in a busy store, or a large chain of stores, where 
such packages are sold, the fraud may aggregate several dollars per day, and in the course of a year amount to a very large sum of money.

It is considered unnecessary to go into great detail here. Weights and measures officials are familiar, or at least should be familiar, with many of the tricks and schemes used possibly to a much larger extent than the general public believes.

It is the function of a weights and measures department to see that purchasers of merchandise receive the quantity for which they pay. That is a duty which should be fully performed. As indicated in the beginning, it is not enough to see that scales, measuring pumps, and other devices are correct. The performance of that duty is only a preliminary step in the accomplishment of the real purpose for which a weights and measures department is maintained.

Every well organized weights and measures department should maintain a staff of keen-minded investigators and undercover buyers. The value of such a staff to the people of every city can hardly be overestimated. They discover the evidence upon which prosecutions are based, assist in preparing cases for court, appear as witnesses, and act as consultants for prosecuting attorneys. These investigators should be persons of unusual intelligence, and well informed regarding methods pursued in every line of business.

The weights and measures department of the District of Columbia lacks much of having the facilities and the number of employees needed to protect the public in this city. Nevertheless, the department has done a considerable amount of work along the lines indicated, and in some instances the results have been astounding.

Only a few specific instances will be discussed.

Last year an investigation was made regarding the sale of gasoline to motorists. A man not generally known to be an employee of the weights and measures department was detailed to visit filling stations, converse with employees, and otherwise obtain all the information possible in regard to the way the business was being operated. It was not possible, of course, to have him visit all the filling stations in the city, but he investigated the operation of a number owned by different concerns. It was not long before the information obtained by him indicated that a large amount of fraud was being perpetrated at filling stations owned by a corporation operating more than 60 stations in this city. It was then decided to have an undercover buyer make purchases at stations operated by the corporation in question. Eight stations were selected for making trial purchases. Each purchase was of 5 gallons. Out of 36 purchases made, short measure was delivered 23 times. The shortages were from 6 ounces to 2 gallons on each purchase. Several of them amounted to 1 gallon or more. In other instances the short measure amounted to almost a gallon. Prosecution was instituted against the corporation. It employed two of the largest firms of lawyers in Washington to defend it, but finally paid $\$ 1,000$ without going into court to fight the case.

The facts in this case clearly tended to indicate that the methods pursued by the corporation in connection with its requirements of accounting on the part of its employees was largely responsible for the sale of short measure at its filling stations. Its methods were investigated in much detail. After prosecution the methods of the concern were changed. 
Very recently undercover buyers for the District of Columbia weights and measures department made a large number of purchases of meats from stores catering chiefly to laboring people, both Negroes and whites, and to persons on relief rolls.

Records of a few of the purchases made are included:

Store 1.-February 2, 1935. Shoulder, represented to weigh 4 pounds, 3 ounces, actual weight 3 pound, 5 ounces, short weight 14 ounces; February 2, 1935. Beef roast, represented to weigh 9 pounds, 7 ounces, actual weight 8 pounds, 6 ounces, short weight 1 pound, 1 ounce; February 9, 1935. Ham, represented to weigh 8 pounds, 10 ounces, actual weight 8 pounds, short weight 10 ounces; February 9, 1935. Beef roast, represented to weigh 8 pounds, 13 ounces, actual weight 8 pounds, 9 ounces, short weight 4 ounces.

Store 2.-February 4, 1935. Smoked shoulder, represented to weigh 11 pounds, actual weight 9 pounds, 14 ounces, short weight 1 pound, 2 ounces; February 4 , 1935. Lard, represented to weigh 2 pounds, actual weight 1 pound, 13 ounces, short weight 3 ounces; February 9, 1935. Shoulder, represented to weigh 5 pounds, 5 ounces, actual weight 5 pounds, short weight 5 ounces; February $9,1935$. Beef roast, represented to weigh 4 pounds, 9 ounces, actual weight 3 pounds, 11 ounces, short weight 14 ounces; February 9, 1935. Shoulder, represented to weigh 5 pounds, 12 ounces, actual weight 5 pounds, 8 ounces, short weight 4 ounces.

Store 3.-February 5, 1935 . Smoked shoulder, represented to weigh 5 pounds, 10 ounces, actual weight 4 pounds, 14 ounces, short weight 12 ounces; February 5,1935 . Corned shoulder, represented to weigh 5 pounds, 7 ounces, actual weight 4 pounds, 14 ounces, short weight 9 ounces; February 5, 1935 . Fresh shoulder, represented to weigh 5 pounds, 8 ounces. actual weight 4 pounds, 11 ounces, short weight 13 ounces; February 5, 1935. Beef roast, represented to weigh 6 pounds, 10 ounces, actual weight 5 pounds, 8 ounces, short weight 1 pound, 2 ounces; February 5, 1935. Fresh shoulder, represented to weigh 5 pounds, actual weight 4 pounds, 6 ounces, short weight 10 ounces.

Store 4.- March 2, 1935. Smoked shoulder, represented to weigh 5 pounds, 6 ounces, actual weight 4 pounds, 11 ounces, short weight 11 ounces; March 2, 1935. Roast beef, represented to weigh 5 pounds, actual weight 4 pounds, 9 ounces, short weight 7 ounces; March 9, 1935. Smoked shoulder, represented to weigh 4 pounds, 14 ounces, actual weight 4 pounds, 5 ounces, short weight 9 ounces.

Similar short weights were received at other stores. It would make this paper too long to include all of them. In all the stores mentioned, scales were correct. The fault was with the management.

The instances referred to show conclusively to my mind the value of employment of undercover buyers. In all cases similar to those herein mentioned the store proprietors were prosecuted. Fines ranged from $\$ 75$ to $\$ 250$.

A few weeks ago purchases of breakfast bacon made by one of our buyers at several stores of one of the chain systems operating here showed an average of 7 percent short weight. Prosecution has been instituted, but the case has not yet been terminated.

For a good many years Congress has made a small annual appropriation of funds for our department to use in making undercover purchases. The appropriation is not as large as might well be employed. Most of the time in the past the appropriation has been $\$ 500$ per year. When the facts regarding our discoveries were placed before the Appropriations Committee of the Senate at the present session of Congress the committee not only doubled the amount for undercover buying, but also provided for a substantial increase in our investigational force.

In conclusion, I wish to say that during the present year, my office has had the hearty cooperation of the consumers council of the District of Columbia, which has been very much appreciated. 
The Chairman. Thank you, Mr. Roberts.

Mr. Holbrook. I think that the Conference owes a vote of thanks to Mr. Roberts for his consideration in displaying his test truck to us for so long a period of time at the Bureau. I think the Conference appreciates your assistance, Mr. Roberts.

The Chairman. We are very glad you did so, Mr. Roberts.

Mr. Roberts. I am always glad to attend these National Conferences. We are always glad to have officials from other cities come here.

\section{REPORT OF COMMITTEE ON RESOLUTIONS, PRESENTED BY} C. D. BAUCOM, CHAIRMAN

Your committee on resolutions desires to submit the following resolutions for your consideration.

\section{IN MEMORY OF DR. SAMUEL W. STRATTON}

Whereas by the death of our most dearly beloved and esteemed ex-president and former Director of the National Bureau of Standards, Dr. Samuel W. Stratton, this National Conference on Weights and Measures has lost one of its most valuable, enthusiastic, and sincere members; and

Whereas Dr. Stratton through his keen foresight and realization of the importance of weights and measures and their relations to the masses of the people, originated the idea and developed it into the formation of this National Conference: Therefore be it

Resolved, That we of the National Conference on Weights and Measures, assembled at the National Bureau of Standards, Washington, D. C., June 4-7, 1935, do hereby pass this resolution in memory of our departed brother; and be it further

Resolved, That this resolution be made a part of the record of this Conference, and that a copy be sent by the secretary to Dr. Stratton's family.

\section{IN MEMORY OF DR. GEORGE K. BURGESS}

Whereas by the death of our dearly beloved president, Dr. George K. Burgess, this National Conference on Weights and Measures has lost.one of its most valuable members, and

Whereas Dr. Burgess was ever ready with counsel and encouragement to assist any one of us in meeting the problems of this work: Therefore be it

Resolved, That we of the National Conference on Weights and Measures, assembled at the National Bureau of Standards, Washington, D. C., June 4-7, 1935 , do hereby pass this resolution in memory of our departed brother; and be it further

Resolved, That this resolution be made a part of the record of this Conference, and that a copy be sent by the secretary to Dr. Burgess's family.

(After the reading of the above resolutions it was moved and seconded that these be adopted by a rising vote, the question was taken in the manner suggested, and the motion was thus agreed to.)

\section{IN MEMORY OF OUR DEPARTED BROTHERS}

Whereas we have lost from our ranks since the last Conference in 1931, through the plan of Divine Providence, a goodly number of our members; and

Whereas our associations with these gentlemen have been an inspiration in prompting us to go forward with a greater determination to carry on the ideals set by them: Therefore be it

Resolved, That we of the National Conference on Weights and Measures, assembled at the National Bureau of Standards Washington, D. C., June 4-7, 1935 , do hereby draw up this resolution as an expression of our sincere sorrow at their passing.

\section{APPRECIATION TO OFFICIALS COOPERATING}

Whereas the Governors, county, and city officials of the various States, counties, and cities, through their manifest interest in weights and measures work, have made it possible by their cooperation for their jurisdictions to be represented at 
this, the Twenty-fifth National Conference on Weights and Measures, held in the Nation's Capital at Washington, and

Whereas such cooperation and attendance have made it possible to adopt uniform. regulations for the various jurisdictions, and in various other ways to facilitate the improvement of weights and measures departments: Therefore be it

Resolved, That a letter of appreciation with a copy of this resolution be forwarded to these various officials by the secretary of the Conference thanking them for their cooperation.

\section{APPRECIATION TO THE DIRECTOR AND STAFF OF THE NATIONAL BUREAU OF} STANDARDS

Whereas Dr. Lyman J. Briggs, Mr. E. C. Crittenden, and Dr. A. S. McAllister, and their most able and efficient staff, have extended valuable assistance and guidance to this Conference: Therefore be it

Resolved, That this Conference go on record in sincere and grateful appreciation of their cooperation in the making of this Conference a success.

\section{APPRECIATION TO THE PRESS}

Whereas the representatives of the press of Washington have given valuable space in their papers and have given freely of their time in the interest of publicity of the proceedings of our Conference: Therefore be it

Resolved, That we, the Twenty-fifth National Conference on Weights and Measures, express our appreciation to the press for such services.

\section{IN RELATION TO RULES OF PROCEDURE FOR THE NATIONAL CONFERENCE}

Whereas this National Conference on Weights and Measures recommends to the various States and jurisdictions the adoption and enforcement of rules, regulations, specifications, and tolerances promulgated and adopted by this Conference; and

Whereas a large number of such jurisdictions have by law or otherwise accepted and/or carried out the recommendations as promulgated and recommended by this Conference; and

Whereas our procedure in the promulgation of such rules, regulations, specifications, and tolerances has been set more or less by precedent: Therefore be it

Resolved, That this National Conference on Weights and Measures assembled at Washington, D. C., June 4-7, 1935, do hereby adopt the following rules of procedure governing the promulgation, deliberation, and recommendation of such rules, regulations, specifications, and tolerances, subject to amendment from the floor by addition or deletion at the will of the Conference. The will of the Conference shall be determined by a majority vote of the qualified members of the Conference.

1. Immediately following the opening of the conference or as soon thereafter as practicable within the first half of the meeting, the committee on specifications and tolerances shall make report of any contemplated changes or additions in previously adopted rules, regulations, specifications, and tolerances, and any contemplated change or proposal by a member of the Conference shall be presented within this same period, all of which is in order that members may have sufficient time for deliberation and careful study of the proposed changes or additions.

2. In general the procedure shall be in accordance with Roberts Rules on Parliamentary Procedure insofar as it is applicable to this Conference and not contrary to any specific rules and regulations adopted by this Conference.

3. The program committee shall arrange for sufficient time to be granted members of the Conference to fully discuss on the floor the weights and measures problems confronting them in their jurisdictions and obtain from the exchange of ideas ways and means of coping with similar problems.

4. Such matters as are referred to the committee on specifications and tolerances shall be reported back to the Conference as soon as possible, with their recommendations, in order that free discussion may be had prior to final action by the Conference.

5. It is the wish and desire of this Conference that any member having in mind the introduction of a new rule, regulation, specification, or tolerance or the introduction of a proposition of special interest to the Conference, send to the secretary of the Conference, well in advance of the meeting at which such pro- 
posal is to be considered, a copy of such proposal in order that such action as necessary may be taken by either the program committee or the committee on specifications and tolerances in relation thereto.

\author{
(Signed) C. D. Baucom, Chairman, \\ JoHN J. LEvitT, \\ George S. Barnard, \\ William F. Steinel, \\ Jacob M. VANDERSLICE, \\ Alexander Hamilton, \\ Walter F. Stilles,
}

Committee on Resolutions.

\title{
DISCUSSION OF ABOVE REPORT
}

(It was moved and seconded that the third resolution "In Memory of Our Departed Brothers" be adopted by a rising vote, the question was taken in the manner suggested, and the motion was thus agreed to.)

Mr. BAucom. In relation to the seventh resolution, the last to be read, I may say, gentlemen, that this has been drawn up with the idea that it will help along the good will and harmony of this Conference. We have drawn this resolution for your valuable consideration; and for adoption if you see fit to take this step.

(It was moved and seconded that the seventh resolution be adopted.)

Mr. Rogers. In relation to the last resolution read, relative to procedure, I don't think the matter can be handled in that way even if it be the wish of the Conference that something of that nature really ought to be done, since the Conference has never adopted a constitution or a set of bylaws.

I move that this resolution be tabled.

(The motion was seconded.)

Mr. BAucom. I am not going to contend or argue for the resolution. To explain it, however, I may say that there seemed to be a feeling among some of the delegates here that they were not given an opportunity to express themselves and exchange ideas. It is true that we do not have any constitution or bylaws. We have no rules and regulations to control our activities. Such things have been proposed two or three times in the past, but have never been adopted. It seemed fitting then, that we could at least recommend a resolution at this time that could be granted consideration, on problems of vital interest to the delegates.

The Chairman. I wonder whether you had in mind program item 35, "General Consideration of Subjects of Interest and Questions Brought Up for Discussion by Officials."

Mr. BAUCOM. It is true that there is such an item, but this comes so late in the program we never get to it. We think it should be moved up so that we get to it before the conference is nearing a close, when we have some of these other items at the end of the program moved ahead of it. If you gentlemen do not want the resolution, I am quite sure it is all right so far as I am concerned. We just wanted to do what we thought was best for the conference.

The Chairman. The motion before the house is to lay on the table the resolution of the committee in relation to procedure.

(The question was taken by yea-and-nay vote, and the issue was in doubt. Thereupon a rising vote was taken and upon the count showing 15 in favor of the motion to table and 14 opposed, the motion was agreed to.) 
(It was moved and seconded that the remaining resolutions of the committee not yet considered be adopted as presented by the committee, the question was taken, and the motion was agreed to.)

\section{CREATION OF COMMITTEE ON CONSTITUTION AND BYLAWS}

Mr. Griffith. Mr. Chairman, I think we have a way of meeting the situation so lately presented by the committee on resolutions, and which it is very evident should receive consideration and attention. I make the motion that the Chair, or the president, appoint a committee of not less than three members of the conference to draw up a constitution and set of bylaws for the guidance of this organization.

This year more than 50 percent of the officials in attendance were new men, entirely unacquainted as to how to go about it, to do anything. Certainly a body of the size of this-over 200 attendantsshould have rules and regulations of procedure. It is marvelous to see the great amount of work we accomplish more or less in a haphazard way. I think it will be a step forward, and will better maintain our balance and simplify our procedure, to have drafted a constitution and bylaws.

(The motion was seconded, the question was taken, and the motion was agreed to.)

\section{REPORT OF THE TREASURER, GEORGE F. AUSTIN, JR.}

Recəipts:

Balance on hand June 1, 1931

Dues from delegates. \$74. 84

Interest received

Total receipts

Disbursements:

$(5$ receipt books _. .

Flowers in memory of H. J. Foley ... 10.00

Wreath in memory of L. A. Fischer...... 10.00

1931, June 1 Candy for stenographers

Cigars for reporter

Fees (2 messengers)

Telephones_......... 10

Flowers in memory of W. A. Payne_...- 10.00

1932, May 6 Wreath in memory of L. A. Fischer.... 10.00

Wreath in memory of Dr. G. K. Burgess.... 10.00

Total disbursements__._._. 88.95

Balance on hand June 1, 1935

Respectfully submitted.

(Signed) Geo. F. Austin, Jr., Treasurer.

(The report was duly accepted.)

\section{CONSIDERATION OF HOTEL HEADQUARTERS FOR THE TWENTY. SIXTH NATIONAL CONFERENCE}

The Chairman. Gentlemen, the next item of business is the selection of hotel headquarters for the Twenty-Sixth National Conference.

Mr. HolbRook. We have proposals from three hotels in town, namely, Hotel Washington, The Willard, and The Mayflower. We circularized the members of the executive committee on additional hotels this year, but it is believed a satisfactory choice can be made from among these three. 


\section{(Mr. Holbrook read the proposals.)}

Mr. NASON. I believe we ought to take a hotel where it is possible for some of the men to get rooms for $\$ 2$ and $\$ 2.50$. The reason there were not more city men here at this Conference is that in some cities the salaries are small, and it isn't easy for them to pay higher rates.

Mr. Rogers. I feel that so many delegates come here representing widely separated sections, that it would be advisable to refer this matter to the executive committee of the Conference. I put that in the form of a motion. to.)

(The motion was seconded, the question was taken, and the motion was agreed

\section{MOTION IN RELATION TO EXPENDITURES}

Mr. Rogers. Mr. Chairman, I would like to offer a motion that the secretary be authorized to pay the customary expenses incident to this Conference and that Mr. Holbrook's draft upon the treasurer be honored by Mr. Austin, treasurer.

(The motion was seconded, the question was taken, and the motion was agreed to.)

\section{TRIBUTE TO JOHN H. AUSTIN}

The Chairman. Just before we adjourn, I am going to ask the delegates of this Conference to bear with me, as there is one matter which weighs heavily on my mind, the accidental death of John $\mathrm{H}$. Austin, delegate from Maine. As we prepare to go back to our homes, we remember that John Austin cannot do that. I am going to ask the Conference to stand in silence for a brief moment in tribute to our departed delegate.

(The members of the Conference stood in tribute to John H. Austin.)

Mr. Griffith. The last number on the program is "Suggestions for Program of Twenty-Sixth Conference." This might well be considered by the various delegates, between now and next year, and I would suggest that from time to time as suggestions of interest arise, they forward these suggestions to the secretary of the Conference. If we wait until the approach of the date of the next Conference these suggestions will be lost, and we will be without the advantage of valuable items. I suggest especially that new members avail themselves of this opportunity. I offer the facilities of my office to any delegate for any information which I may be able to give them.

Mr. BAucom. Before we adjourn; did the chair appoint a committee to draw up a constitution and bylaws?

The Chairman. It is the wish of the Chair to allow that power to rest in the hands of the president of the Conference, Dr. Briggs. Mr. Baucom. I did not understand the motion that it be left in the hands of the president to do that.

The Charrman. I want to make that clear. I will take no action in relation to the appointment of that committee.

(A motion was made and seconded that the Conference adjourn, the question was taken, and the motion was agreed to.)

(Thereupon, at 1:13 p. m., the Twenty-Fifth National Conference on Weights and Measures adjourned sine die.)

$34678-36-11$ 




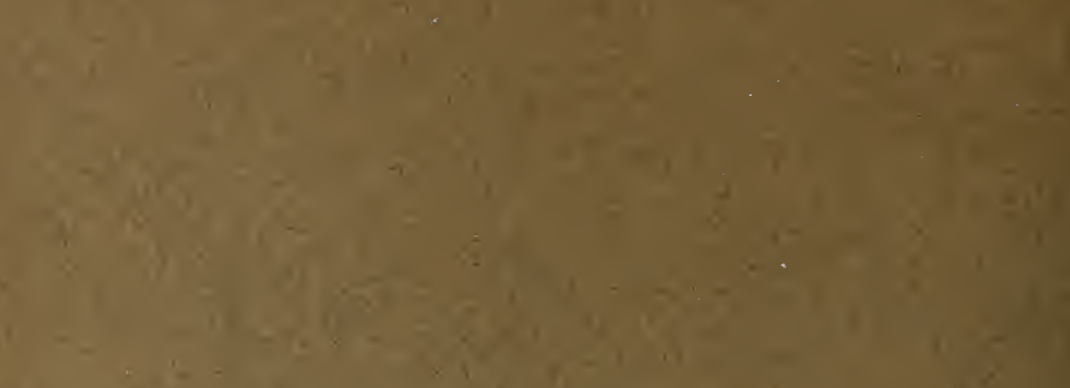

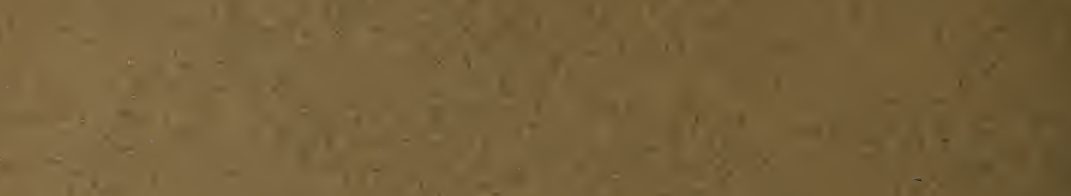

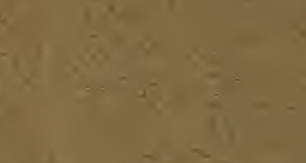

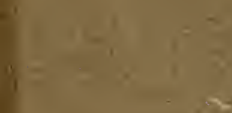

$x-2=49$

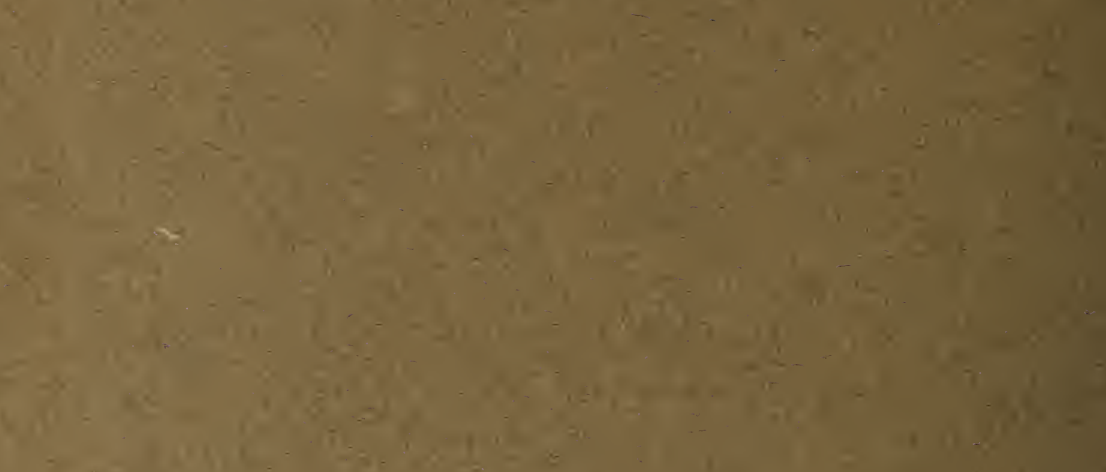

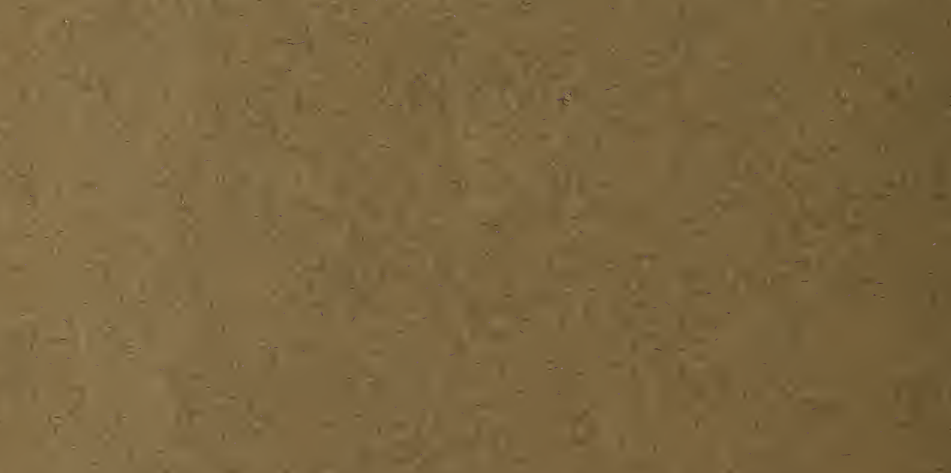

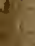
$y^{2} y^{4} x-8$

30
254

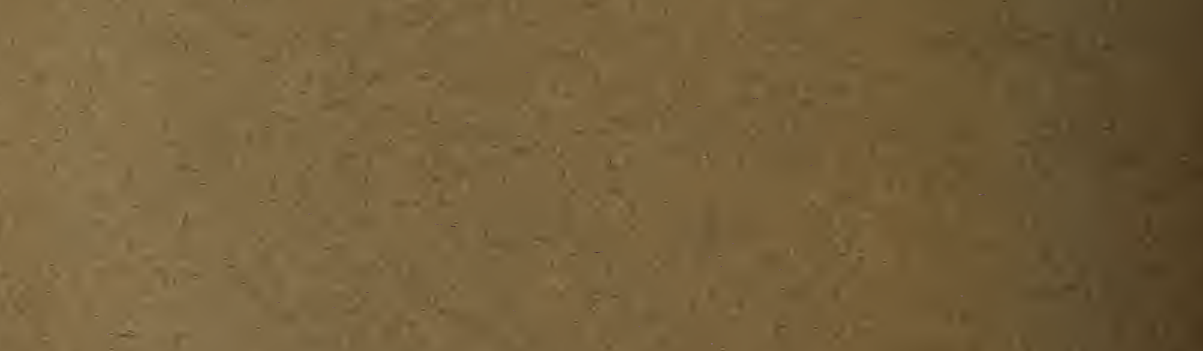
$y=$

$-$ 